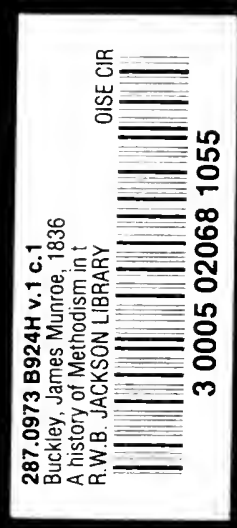




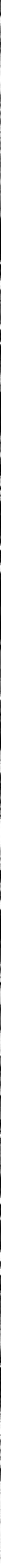




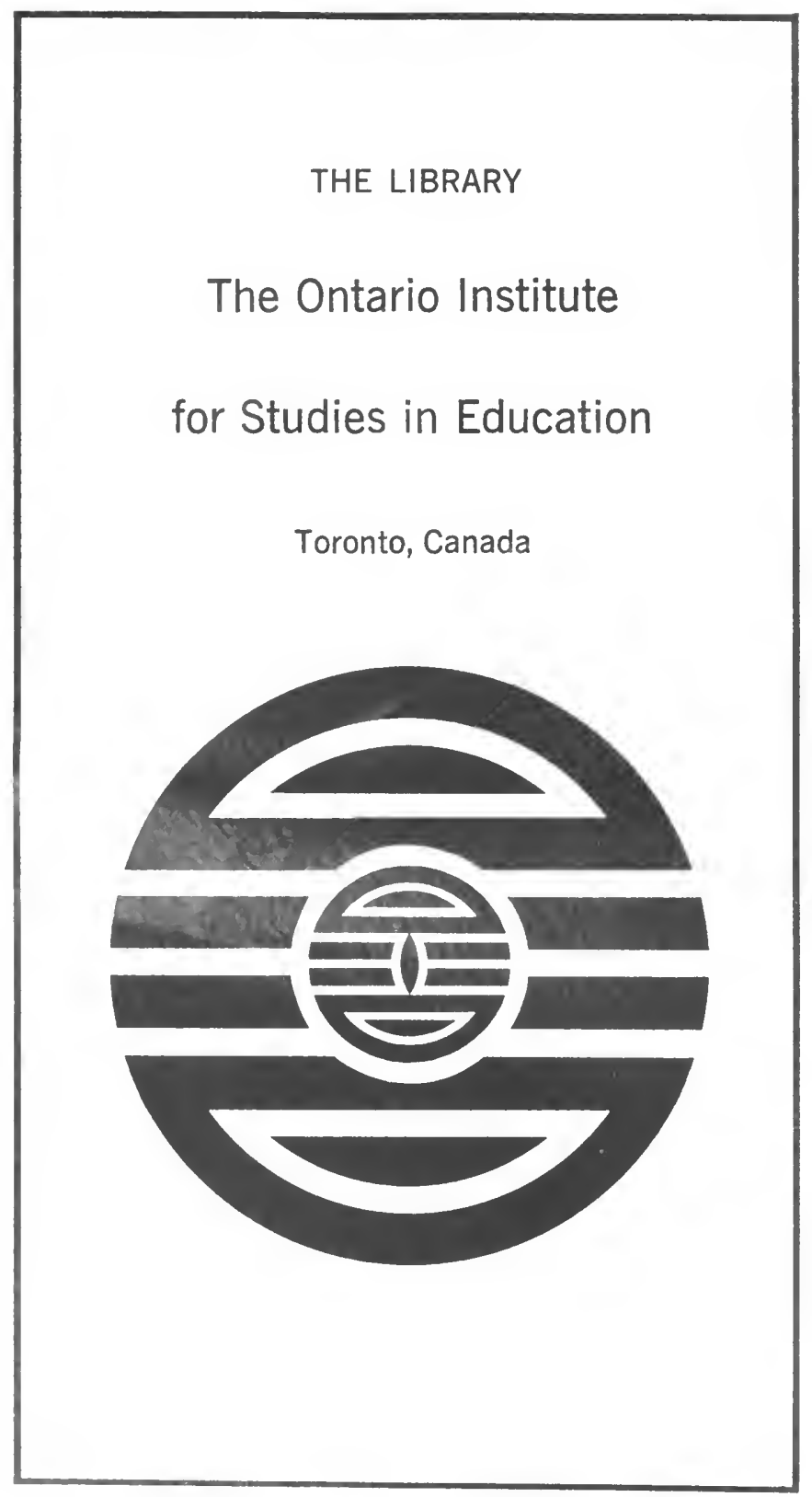


THE ONTARIO INSTITUTE - OR STUDIES IN EDUCATION LIBRARY

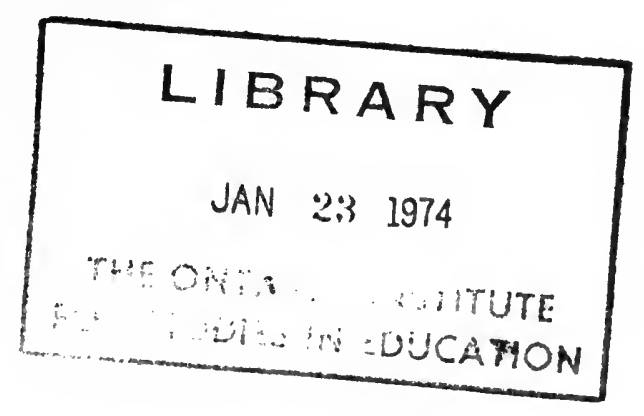




\section{Digitized by the Internet Archive in 2008 with funding from Microsoft Corporation}





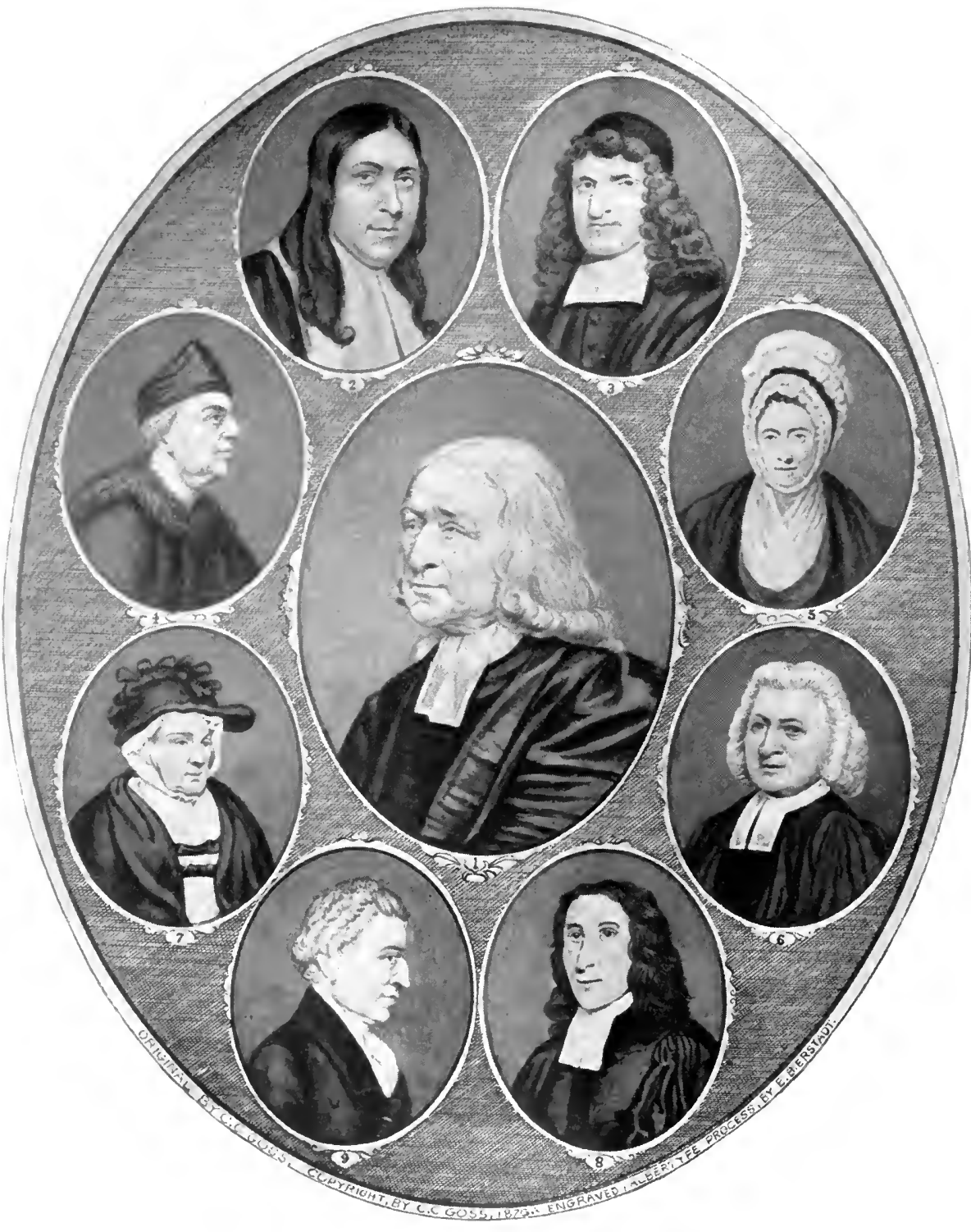

THE WESLEY FAMILY.

1. JOHN WESLEY.

2. Samuel AnNesley,

MATERNAL GRANDFATHER.

3. JOHN Wesley,

PAJERNAL GRANDFATHER.

4. Samuel Wesley,
5. Susannah Wesley,

MOTHER.

o. Charlas Wesley,

7. Sarah Westery,

WTFE OF (:HARLES.

8. Samuli, Wesley, 


\section{A \\ HISTORY OF METHODISM \\ IN THE \\ UNITED STATES}

BY

JAMES M. BUCKLEY

IN TWO VOLUMES

JHustrated

VoL. I

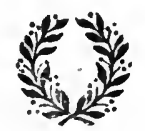

NEW YORK

THE CHRISTIAN LITERATURE CO. MDCCCXCVII 
Copyright, 1897, by

The Christian Literature Co.

Press of J. J. Little \& Co.

Astor Place, New York 


\section{CONTENTS.}

Bibliography. $\ldots \ldots \ldots \ldots \ldots \ldots \ldots \ldots \ldots \ldots \ldots \ldots \ldots \ldots \ldots \ldots$

Preliminary $\ldots \ldots \ldots \ldots \ldots \ldots \ldots \ldots \ldots \ldots \ldots \ldots \ldots \ldots \ldots \ldots \ldots \ldots$

CHAP. I.-The Fatheriand of METhodism.-Medieval English

Christianity. - Revolt of Henry VIII. from the Pope.-Estimate of his Reign.-Regal Vicissitudes.-The Fires of Persecution. -The Protestantism of Elizabeth.-Inconsistencies of James I. Usurpations of Charles I.-Presbyterianism and the Commonwealth. - Degenerate Reign of Charles II. - William and Mary. -

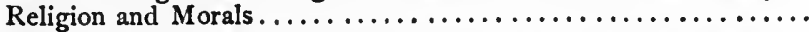

CHAP. II.-Progenitors of THE Founder. - The Rev. Bartholomew Wesley. - The First John Wesley.-His Persecutions and Death.-The "Patriarch of Dorchester."-Early Life of Samuel Wesley.-Changes his Religious Views.-Ordination and Mar. riage.-Ancestry of Susannah Wesley.-Her Character.-Domes-

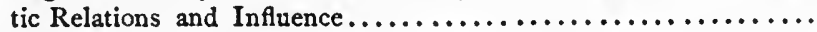

CHAP. III.-The MaN of Providence.-Childhood of John Wesley.-At Charterhouse School.-Development in Oxford.-Ordination and Fellowship.-A New Religious Movement.-Moral Darkness of the Age. - Death of his Father.-Missionary to Georgia.-John's Disappointments and Conflicts. - Indicted by Grand Jury. - The Reasons for Refusal to Sign................

CHAP. IV.-GeNesis AND Growth of METhodism. - Wesley Emerges into Light.-In Herrnhut.-Preaching the New Evangel.-Controversy with Whitefield.-Issue with Calvinism Accentuated.-Formation of Methodist "Societies."-Erection of Chapels.-The First Conference. - Doctrines, Rules, and Institutions. Charles Wesley.-Jean Guillaume de la Fléchère............

CHAP. V.-IN THE NEw WoRLD.-Embury and his Companions.Barbara Heck's Appeal._-Increasing Attendance._- "The Old Sol- 
dier."-The First Methodist Church.-Peculiar Legal Document. -The Dedication.-Origin of Methodism in Maryland.-A Question of Priority.-Appeal to Wesley for Preachers.-Arrival of Robert Williams.-Men and Means,-Death of Whitefield.-Exploits of John King.-Asbury Sails for America.-Amenities and Toils.-Parson versus Preacher.-Stipends-Criticisms-Hospitality.-Cowing beside all Waters. - Powerful Reinforcements....... II3

ChaP. VI.-Early American Conferences.-Minutes of First Conference.-Human Nature not Extinguished.-The Second Conference.-Boardman and Pilmoor Return to England.-Influential Accessions.-Exploits of Philip Gatch.-Portents of Civil War.-Coincidence of Conference and Congress.-New Form of

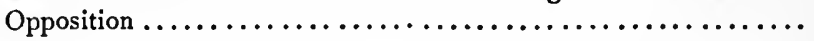

CHAP. VII.-IN THE Throes of Revolution.-Wesley and the American Cause.-Wesley's Forgetfulness.-The Vital Error.Wesley's Own Testimony. - Explanation of Wesley's Course.Conspicuous Triumphs. - Declaration of Independence. - The Conference of 1777. - Asbury Forsaken.-Arrest of Judge White.Judge Bassett's Heroism. - Defining Asbury's Prerogatives. - Selforiginated Ordinations. - Erection of " Barrett's Chapel."-Alarming Discord. - Rapid Increase in Members. - National Jubilation. Methodism in New York City.-New Opportunities. - Stringent Rules against Slavery.-Asbury's Opponents Silenced by Wesley. 196

CHAP. VIII.-Blended Romance and Reality.-The Typical Itinerant.-Benjamin Abbott.-Strange Experiences.-Views of Southey and Coleridge.-Jesse Lee as a Soldier.-A Pathetic Appeal.-Unity in Diversity.-Moral and Mental Pathology.-Rational and Scriptural Discipline.-Spiritual Influences.-Distinguishing the Human and the Divine................... 245

CHAP. IX.-ORganization of The Methodist Episcopal Church. -Coke Becomes a Methodist.-Wesley's "Deed of Declaration." -Wesley Conferring with Coke._-Ordinations by Wesley.-Wesley's Explanatory Statements.-Evidence of his Consistency.-First Meeting of Coke and Asbury.-Ordination of Asbury.-First Discipline of the Church.-Important Provisions.-Liturgy and Doctrinal Standards .......................... 27

CHAP. X.-From the Ordination of Asbury to the Death of Wesley.-The Slave Question.-Coke's Difficulties.-Misunderstandings with Wesley. - The New Name of the Superintendents.Vicissitudes.-Methodism Enters New England.-The "Council." -The Bishops to the President. - The President to the Bishops.Controversies and Conversions.-Asbnry and Sunday-schools. - 
Wilberforce and John Howard.-Wesley as a Preacher.-His Last Letter to the United States. - Results of his Long Life ......... 299

CHAP. XI.-OUt of the Old Century into the New.O'Kelly's Discomfiture.-Hammett and Meredith Separate.Methodism Assailed in Connecticut.-Cokesbury College Destroyed.-General Conference of 1796. - Losses and Gains.-Asbury Proposes to Resign.-Antislavery Legislation.-Camp-meetings,

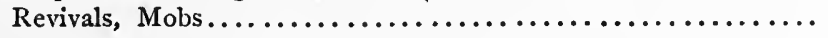

CHAP. XII.-Troublous yet Successful Years.-Time Limit for the Pastorate.-Aaron Hunt's Account.-Methodism in the British Colonies. - Members of African Descent.-Beginnings of Race Churches. -An Untutored Genius. - Fruits of the Year.... 363

CHAP. XIII.-Introduction of Representative Government. - Controversy Concerning Coke.-Coke and Bishop White.-Reconciliation of Coke and the Conference.-Coke and the Bishop of London.-McKendree Elected Bishop.-Sketch of McKendree.Proposals for a Delegated Conference.-Plan for a Representative Body.-Debate, Compromise, and Constitution.-Elections and Regulations. - Religious Influence of Conference .......... $33^{82}$

CHAP. XIV.-Evolution UNDER A ConstituTion.-Introduction of New Methods.-A Vexed Question Reappears. - The Death of Coke.-The Death of Asbury.-Rise of African Churches.-Election of Bishops George and Roberts.-Axley's Perseverance Triumphs.-Debt of Methodists to Women.-General Conference of 1820.-Constitutional Controversies ................. 408

CHAP. XV.-Critical Discords and Comprehensive ENTERPRISES.-Inconsistent Legislation. - " Zion's Herald" Founded.Heresy Trials.-Expulsions and Withdrawals. - The Methodist Protestant Church.-Canadian Methodism.-Large Numerical Increase.-Election of Andrew and Emory.-Seminaries and Colleges. - Tragic Events.-Election of Three Bishops.-Methodism Planted in Texas. -General Conference of $1840 \ldots \ldots \ldots \ldots \ldots \ldots \ldots$ 


\section{LIST OF ILLUSTRATIONS.}

Wesley Family Group Frontispiece

PAGE

John Summerfield $\ldots \ldots \ldots \ldots \ldots \ldots \ldots \ldots \ldots \ldots \ldots \ldots \ldots \ldots$ xvii

John IVESLEY............................ XXii

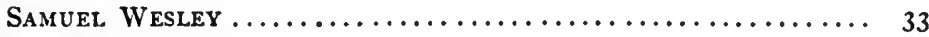

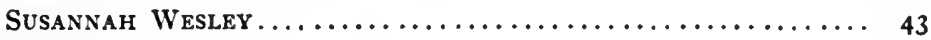

EPWORTH RECTORY............................ 54

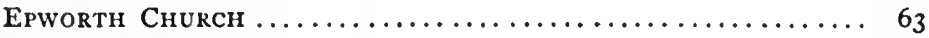

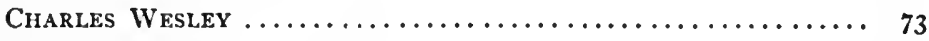

THE " FoundRY" ............................. 95

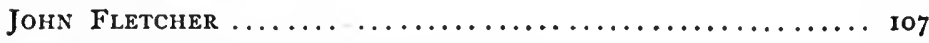

GeORGE Whitefield ......................... II2

Embury's Account of His Conversion ................ 115

Captain Webr............................ 23

John Street Church........................ I27

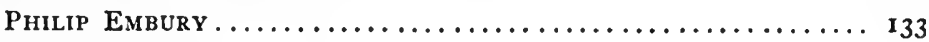

Barbaka Heck ............................ 137

Richard BoARdMAN ....................... 147

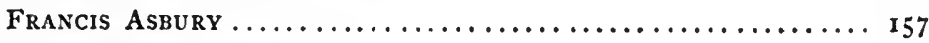

Loveiy Lane Chapel......................... 165

THOMAS RANkIN ............................ I69

Robert Strawbridge........................ 179

vii 
viii LIST OF ILLUSTRATIONS.

Joseph Pilmoor $\ldots \ldots \ldots \ldots \ldots \ldots \ldots \ldots \ldots \ldots \ldots \ldots \ldots \ldots, \mathbf{1}_{3}$

FREEBORN GARRETtSON............................. 209

Memorial Tablet of John Dickins .................. 213

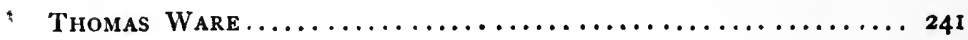

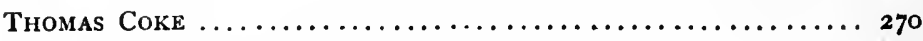

Facsimile of Page of Wesley's Journal .............. 277

Richard Whatcoat .......................... 289

WiLLiAM MCKeNDREE........................... 307

Memorial Tablet in Westminster Abbey ............... 325

Death-bed of Wesley............................ 333

WesLey's Grave................................. 337

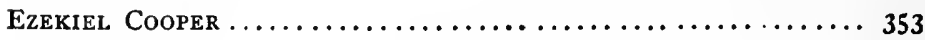

Henty Boema.................................. 357

Martin Ruter ............................... 371

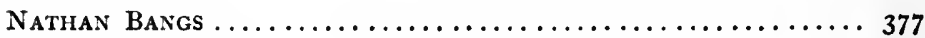

ROBERT R. ROBERTS ............................ 383

Elijah Hedding............................... 4 or

Nicholas Snethen ............................. $4 \mathbf{1} \mathrm{I}$

John EMORY................................. 4 19

ENoch George ............................... 423

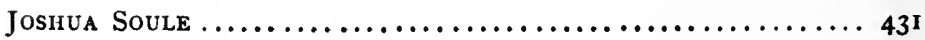

WILBUR Fisk................................... 44

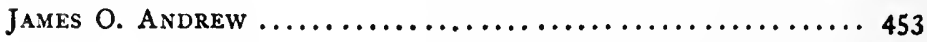

John P. Durbin............................... 457

Peter Akers $\ldots \ldots \ldots \ldots \ldots \ldots \ldots \ldots \ldots \ldots \ldots \ldots \ldots \ldots \ldots, 46 . \ldots \ldots$

WilliaM NAST $\ldots \ldots \ldots \ldots \ldots \ldots \ldots \ldots \ldots \ldots \ldots \ldots \ldots, 467$ 


\section{BIBLIOGRAPHY.}

THE following catalogue, arranged alphabetically under authors' names, includes but a minority of the volumes consulted in the preparation of this work. In some instances they have been published in various editions and by several publishers. Next to the official journals and other documents of the different denominations, the most important authorities are the personal journals of Wesley, Coke, Asbury, Garrettson, and other founders ; the histories of Jesse Lee, Nathan Bangs, and Abel Stevens, in particular the lastnamed, whose works are invaluable and deserve the everlasting gratitude of both English and American Methodism. Bond, Emory, and Wakeley rendered valuable service; and Neely and Tigert pursued, in the order of time in which their names are placed, important investigations into the subjects comprehended under the titles of their works, and displayed the results in a clear and comprehensive manner.

"The Wesley Memorial Volume," edited by Clark, and the "Lives of Methodist Bishops," edited by Flood and Hamilton, are very useful, the latter containing an immense amount of information in small compass.

The special histories of the various branches of American Methodism, and the biographies of their founders, are indispensable.

Among the biographies none surpasses Paine's "Life of McKendree," which is a mine of antiquarian knowledge and a repository of the writings of McKendree, Soule, and other controlling minds among those who gave Methodism its final forms.

The "History of the Methodist Episcopal Church, South," by Gross Alexander, treats many interesting phases of the life and growth of that body, and afforded aid in investigations required by the plan of this work. The works of Lucius C. Matlack on the slavery controversy admirably fill a place occupied by no other productions.

The reports of different organizations, the minutes of Annual Conferences, the "Methodist Magazine," the reviews, and the files of the weekly periodicals of American Methodism have been searched, and a large mass of unpublished epistolary correspondence and other manuscript examined. It is believed that the bibliography here given will afford sufficient indication to those who may desire to examine authorities. 
Alexander, Gross, D.D., History of the Methodist Episcopal Church, South. Vol. xi., American Church History Series.

Asbury, Francis, Journal. 3 vols. New York, Lane \& Scott.

Atkinson, John, D.D., The Beginnings of the Wesleyan Movement in America and the Establishment Therein of Methodism. New York, Hunt \& Eaton, 1896 .

- Centennial History of American Methodism. New York, Phillips \& Hunt, 1884 .

Baker, Osmon C., D.D., A Guide-book in the Administration of the Discipline of the Methodist Episcopal Church. New York, 1878.

Bangs, Nathan, D.D., A History of the Methodist Episcopal Church. Twelfth edition, revised and corrected. 4 vols. New York, Carlton \& Porter, 1832 .

- Life of the Rev. Freeborn Garrettson, Compiled from his Printed and Manuscript Journals and other Authentic Documents. Fifth edition. New York, Carlton \& Porter, I832.

Bascom, Bishop H. B., Methodism and Slavery.

Appeal of the Southern Commissioners. Nashville, Tenn., Southern Methodist Publication House, 1846.

Bassett, Ancel H., D.D., A Concise History of the Methodist Protestant Church. Pittsburg and Baltimore, I882.

Bond, Thomas E., D.D., Economy of Methodism Illustrated and Defended. , Appeal to Methodists.

Briggs, F. W., Bishop Asbury: A Biographical Study for Christian Workers. Third edition. London.

Carroll, H. K., LI.D., Religious Forces of the United States. Revised. New York, Christian Literature Co., 1896.

Carroll, John, Case and his Contemporaries. 4 vols. Toronto, 1871.

Cartwright, Peter, D.D., Autobiography.

Clark, D. W., D.D., Life and Times of Rev. Elijah Hedding, D.D. New York, Carlton \& Phillips, 1855.

Clark, J. O. A., D.D., The Wesley Memorial Volume. New York, 1880 .

Cooper, Ezekiel, The Substance of a Funeral Discourse Delivered in St. George's Church, Philadelphia, on the Death of Francis Asbury. Philadelphia, Jonathan Pounder, 1819.

Cornish, Rev. George H., Cyclopedia of Methodism in Canada. Toronto and Halifax, $188 \mathrm{I}$.

Crooks, George R., D.D., Life and Letters of the Rev. John McClintock, LL.D. 1876 .

, Life of Bishop Matthew Simpson, of the Methodist Episcopal Church. Harper \& Brothers, I 890 .

Crowther, Jonathan, Portrait of Methodism.

Curry, Daniel, D.D., Life of [Bishop] Davis W. Clark.

Curtiss, George I., M.D., D.D., Manual of Methodist Episcopal Church History. New York, Hunt \& Eaton, I893.

Daniels, W. H., A.M., The Illustrated History of Methodism. New York, Phillips \& Hunt, 1880 .

Deems, Charles F., D.D., Annals of Southern Methodism.

Dorchester, Daniel, D.D., The Problem of Religious Progress. New York, Hunt \& Eaton, 1895. 
Dorchester, Daniel, D.D., Christianity in the United States. New York, Hunt \& Eaton, I895.

Dow, Lorenzo, Journal. Pittsburg, 1849.

Drew, Samuel, The Life of the Rev. Thomas Coke, LL.D. New York, J. Soule \& T. Mason, 1818 .

Elliott, Charles, D.D., History of the Great Secession from the Methodist Episcopal Church. Cincinnati, 1854.

$\longrightarrow$ Life of Bishop Roberts.

Emory, Robert, History of the Discipline of the Methodist Episcopal Church. Revised and brought down to 1856 by W. P. Strickland. New York, Carlton \& Porter.

- A Defense of "Our Fathers," and of the Original Organization of the Methodist Episcopal Church. New York, Carlton \& Porter.

Etheridge, J. W., Life of Dr. Coke. 1860.

Ffirth, John, The Experience and Gospel Labors of the Rev. Benjamin Ab. bott. Philadelphia, 1825 .

Flood, Theodore L., and John W. Hamilton (editors), Lives of Methodist Bishops. New York, Phillips \& Hunt, I882.

Hamline, Bishop L. I., Sermons and Miscellaneous Works.

Harris, Bishop William I., The Constitutional Powers of the General Conference, with Special Application to the Subject of Slave-holding. Cincinnati, I860.

Henkle, M. M., Primary Platform of Methodism.

Hibbard, F. G., D.D., Biography of Rez. Leonidas L. Hamline, D.D. New York, Phillips \& Hunt, 1880.

Hood, Bishop J. W., D.D., One Hundred Years of the African Methodist Episcopal Zion Church. New York, 1895.

Hurst, John Fletcher, D.D., A Short History of the Christian Church.

John, I. G., Handbook of Methodist Missions.

Lednum, John, History of the Rise and Progress of Methodism in America. I859.

Iee, Jesse, $A$ Short History of the Methodists in the United States of America. Baltimore, 18 ro.

Lee, Leroy M., D.D., Life of Jesse Lee.

Lee, Luther, Autobiography. New York, Phillips \& Hunt, I882.

McCaine, Alexander, History and Mystery of Methodist Episcopacy.

McTyeire, Bishop Holland N., D.D., A History of Methodism. Nash. ville, Tenn., Southern Methodist Publication House, 1884. , Manual of Discipline of the Methodist Episcopal Church, South.

Martin, Joel, The Wesleyan Manual; or, History of Wesleyan Methodism. Syracuse, N. Y., Wesleyan Methodist Publication House, 1889.

Matlack, Iucius C., The Antislavery Struggle and Triumph in the Meth. odist Episcopal Church. New York, Phillips \& Hunt, I88I.

- The History of American Slavery and Methodism from 1780 to 1849 , and History of the Wesleyan Connection of America. 2 parts. New York, 1849 .

Merrill, Bishop Stephen Mason, A Digest of Methodist Law. Revised in I888. Cincinnati, Cranston \& Stowe; New York, Hunt \& Eaton.

Moore, H., Life of John Wesley, M.A. 1792.

Neely, Thomas B., D.D., $A$ History of the Origin and Development of the Governing Conference in Methodism. Cincinnati and New York, 1892 . 
Neely, Thomas B., D.D., The Evolution of Episcopacy and Organic Methodism. New York, Phillips \& Hunt, 1888.

Overton, J. H., M.A., John Wesley. Boston and New York, Houghton, Miffin \& Co., 1891 .

Paine, Bishop Robert, D.D., Life and Times of William McKendree. 2 vols. Nashville, Tenn., 1874 .

Payne, Daniel A., D.D., LI.D., History of the African Methodist Episcopal Church. Nashville, Tenn., Publication House of the African Methodist Episcopal Sunday-school Union, 1891.

Phoebus, George A., D.D., Beams of Light on Early Methodism in America. New York, Phillips \& Hunt ; Cincinnati, Cranston \& Stowe, 1887.

Porter, James, D.D., A Compendium of Methodism. Boston, 1851 .

$\longrightarrow$, A Comprehensive History of Methodism. I vol. New York, Phillips \& Hunt; Cincinnati, Walden \& Stowe.

Redford, A. H., D.D., History of the Organization of the Methodist Episcopal Church, South. 1871.

Reid, J. M., D.D., Missions and Missionary Society of the Methodist Episcopal Church. Revised and extended by J. T. Gracey, D.D. New York, Hunt \& Eaton; Cincinnati, Cranston \& Curts, 1895.

Rigg, James H., D.D., The Churchmanship of John Wesley. London, 1878. , The Living Wesley. Second edition revised and enlarged. London, 1891.

Ryerson, Egerton, LL.D., Canadian Methodism: Its Epochs and Char. acteristics. Toronto, 1882 .

Scudder, M. L., D.D., American Methodism. Hartford, Conn., S. S. Scranton \& Co., 1868.

Sherman, David, D.D., History of the Revisions of the Discipline of the Methodist Episcopal Church. Third edition. New York, Hunt \& Eaton; Cincinnati, Cranston \& Stowe, 1890.

- History of Wilbraham Academy. Boston, 1893.

Simpson, Matthew, D.D., Cyclopedia of Methodism. Philadelphia, Everts \& Stewart, 1878 .

, One Hundred Years of Methodism.

Smith, Dr. George, History of Wesleyan Methodism.

Smith, George G., A.M., The Life and Letters of James Osgood Andrew. Nashville, Tenn., Southern Methodist Publication House, 1882.

Smith, T. Watson, History of the Methodist Church of Eastern British America. Halifax, 1877 .

Southey, Robert, LL.D., The Life of Wesley, and Rise and Progress of Methodism. Edited by the Rev. Charles Cuthbert Southey, M.A. Second American edition, with notes by the Rev. Daniel Curry, M.A. 2 vols. New York, Harper \& Brothers, 1847.

Sprague, William B., D.D., Annals of the American Pulpit. Vol. viii. Stevens, Abel, LL.D., History of Methodism. 3 vols. New York, Carlton \& Porter, 1858. - History of the Methodist Episcopal Church. 4 vols. New York, Carlton \& Porter, 1864. , Life and Times of Nathan Bangs, D.D. New York, Carlton \& Porter, 1863.

, The Centenary of American Methodism. New York, 1866.

Sterenson, Edward,'D.D., Sketch of Valentine Cook. Nashville, Tenn., 1858. 
Stevenson, George James, M.A., Memorials of the Wesley Family.

Strickland, W. P., The Pioneer Bishop; or, Life and Times of Francis Asbury. New York, 1858.

Taylor, Isaac, Wesley and Methodism. Harper \& Brothers, I860.

Thrall, Homer S., History of Methodism in Texas. Houston, 1872.

Tigert, John J., D.D., A Constitutional History of American Episcopal Methodism. Nashville, Tenn., Southern Methodist Publication House, 1894 .

Tyerman, L., The Life and Times of the Rev. John Wesley, M.A., the Founder of the Methodists. 3 vols. London, Hodder \& Stoughton. , The Life and Times of the Rev. Samuel Wesley, M.A., Rector of Epworth. Simpkin, Marshall \& Co., 1866.

Urlin, R. Denny, John Wesley's Place in Church History. London, Oxford, and Cambridge, 1870 .

Wakeley, J. B., D.D., Lost Chapters Recovered from the Early History of American Methodism. New York, Wilbur B. Ketcham.

Ware, Thomas, Sketches of his own Life and Travels. New York, 1839.

Watson, Richard, Life of John Wesley. American edition, with translations and notes by John Emory. New York, I857.

Whitehead, John, M.D., Lives of the Wesleys. London, 1793; Auburn and Buffalo, 1844.

\section{Miscellaneous.}

Catalogues of educational and reports of denominational philanthropic institutions.

Discipline of the Methodist Episcopal Church.

Discipline of the Methodist Episcopal Church, South.

Discipline of the Wesleyan Methodist Connection (or Church) in America.

Discipline of the Free Methodist Church.

Discipline of the Methodist Protestant Church.

Discipline of the African Methodist Episcopal Church.

Discipline of the African Methodist Episcopal Zion Church.

Discipline of the Union African Methodist Episcopal Church.

Discipline of the African Union First Colored Methodist Protestant Church.

Handbook of Church Government, Colored Methodist Episcopal Church.

Journals of the General Conference of the Methodist Episcopal Church.

Journals of the General Conference of the Methodist Episcopal Church, South.

Journals of the General Conference of the Colored Methodist Episcopal Church.

Minutes of the Annual Conferences.

Proceedings of the Centennial Methodist Conference.

Proceedings of the First Ecumenical Conference, $188 \mathrm{r}$.

Proceedings of the Second Ecumenical Conference, $189 x$. 



\section{PRELIMINARY.}

THE purpose of this volume is to distinguish Methodism from other forms of Protestant Christianity in the United States; to trace its origin and follow its development, explain the modifications which it has undergone, and to perform these functions for the different denominations into which, in the course of one hundred and thirty years, it has divided. To do these things fully would expand the work to the dimensions of a library. Yet if events be selected with judgment, condensed with rigor, and unfolded in proper order, the result may be a portraiture sufficiently exact to enable those who are to derive their knowledge of Methodism therefrom to recognize the different religious physiognomies delineated, and to suggest to such as desire more extended study the routes of investigation which should be pursued.

There are peculiar difficulties. In the earliest documents dates are often omitted, sometimes incorrectly recorded, and in other cases the same event is by different authors assigned to various dates. The orthography of names is even more uncertain. Reports of important proceedings are frequently partial, and occasionally in legislative enactments phrases are omitted or transposed so as to obscure or modify the sense.

What, however, has been ascertained is herein affirmatively stated; what is doubtful is so represented. The most important facts, after almost incredible pains, have been authenticated.

The scale of the work will not admit of giving all the 
authorities, but in seriously controverted points depending upon a limited number of witnesses they are stated.

Comparatively few local details of the last eighty years are given. The history of Conferences, as of States, must be left to specialists. Yet such acts, however limited in origin, which affected the movements or spirit of one or more of the branches of the tree whose growth is described are recorded.

Methodism from the beginning evoked antagonisms, and until nearly a hundred years had passed was never free from controversy with conscientious opponents. It is not within the province of the historian of his own communion, and in part of his own time, to pronounce judgment upon the motives of those professing "like precious faith." But it is his duty to display their words and actions, and the utterances and deeds of those who antagonized them, so far as possible as they would present them. These, with the results of the conflict, will enable those who read to estimate the relation of events to human and divine providence-the factors in the development of every form of Christianity.

If what is called history be untrue, it is a romance far more dangerous than an avowed work of fiction. Either ignoring pertinent facts or emphasizing them unduly may give to a truthful form of words the effect of falsity.

Methodism is highly organized, and organization implies human centers of power. Hence the characteristics and work of individual men occupy a large place. The history of the body is but the history of those who have made it what it is. This is especially true of churches episcopally governed, the bishops being invested with the power of stationing and removing pastors of churches, and also being $e x$ officio presiding officers in the General and Annual Conferences. As the General Conference 


$$
8
$$




$$
\text { . }
$$

$$
\text { . }
$$


unites the legislative, judicial, and executive prerogatives in one body, it, more than the ruling assemblies of most other denominations, demands a thorough treatment.

The most potent forces which account for the numerical increase of Methodism, the mutual labors of pastors and people in the local societies, are incapable of historic description. Yet without them the visible fabric of Methodism would be as the log hut in which the fathers preached compared with the elaborate ecclesiastical structures which prosperity has made possible.

Many a minister, brilliant in intellect, the luster of whose piety gave a mellow light to the coruscations of his genius, has left no visible trace which the earthly historian can reproduce. Some of these were from other countries, attracted to America by the more rapid growth of Methodism in this free land.

Such was John Summerfield, a native of England, a star of purest ray, who for five years drew all eyes to Methodism by his preaching and platform addresses in behalf of the Missionary Society, the American Bible Society, and the American Tract Society. Yet he was but twentyseven years of age when his vital force was exhausted and his fervent spirit set free.

The succeeding pages will be scanned in vain for the biographies of many such men. The record of their impassioned discourses, their private appeals, their prayers beside those who lay on sick-beds, their words of hope, consolation, or admonition as they stood between the living and the dead, is in the books that shall be opened at the last day. ${ }^{1}$

1 It will be observed that academic and honorary titles are conspicuous by their absence. The limits would not permit their frequent recurrence; in most instances the names are so well known as to make titles superfluous; and in some cases neither the exact degree nor the name of the institution conferring it could be ascertained. 




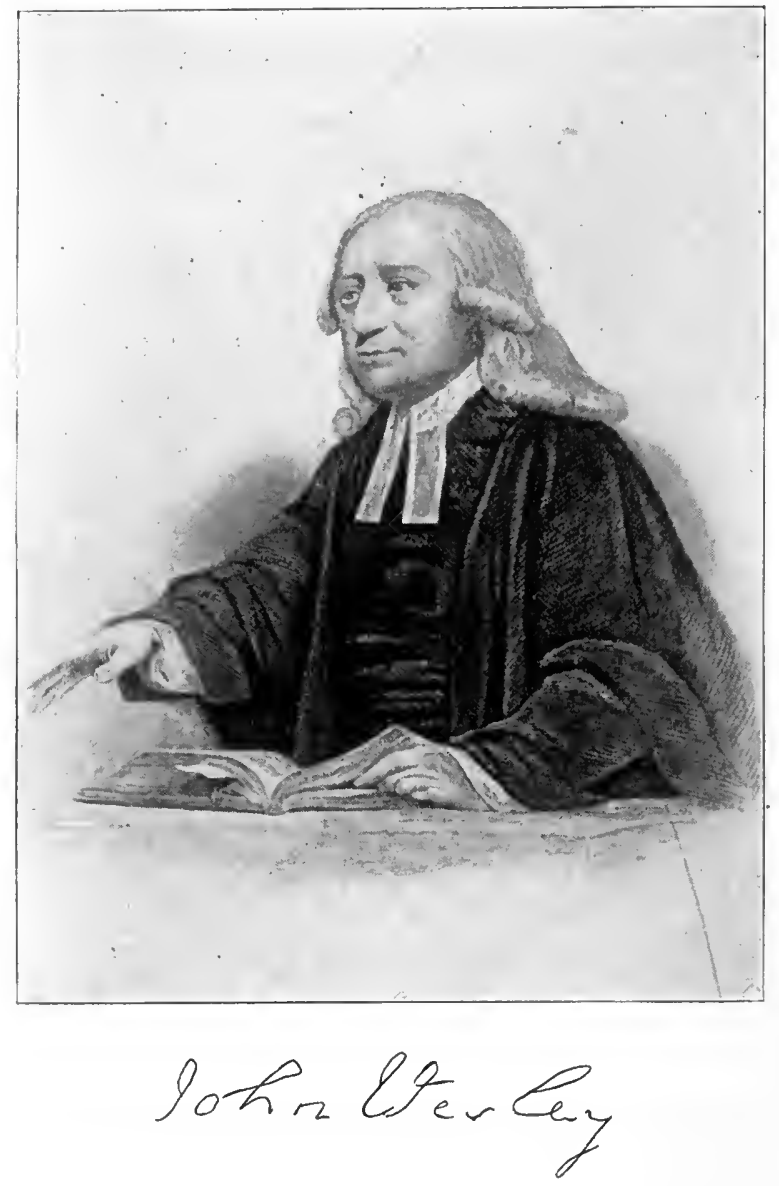




\title{
THE METHODISTS.
}

\author{
CHAPTER I. \\ THE FATHERLAND OF METHODISM.
}

Methodism did not originate in the Western Hemisphere. It was transported across the sea, planted in a fertile soil, and brought forth fruit after its own kind. Montesquieu asserts that "in the infancy of societies the chiefs of the state form the institutions; afterward the institutions form the chiefs of the state." 1

Among the founders of Methodism one name is preëminent. Others either derived their impulse from his persevering and victorious zeal, or submitted to his direction; so that it may be said, with no detriment to their fame, that without him Methodism had not been. Emerson discerned and recognized this in saying: "An institution is the lengthened shadow of one man: as monachism, of the Hermit Anthony; the Reformation, of Luther; Quakerism, of Fox; Methodism, of Wesley ; abolition, of Clarkson. Scipio, Milton called 'the height of Rome'; and all history resolves itself very easily into the biography of a few stout and earnest persons."

1 "Grandeur and Decadence of the Romans," Baker's translation, chap. i., p. $2 \mathrm{I}$. 
It is proposed, therefore, in accounting for the springing of American Methodism fully fledged from the brain and heart of Robert Strawbridge and Philip Embury, to show what formed the moral and intellectual personality of John Wesley, and how he formed Methodism.

For centuries prior to the sixteenth the state of religion and morals throughout the Christian world had steadily deteriorated, although several times during the middle ages the minds of men asserted their fundamental rights against the corruption of Rome. Little knowledge existed, and that was chiefly confined to the clergy. In this period " not one man in five hundred could have spelled his way through a psalm. Books were few and costly. Copies of the Bible, inferior in beauty and clearness to those which every cottager may now command, sold for prices which many priests could not afford to give." 1

Every archbishop of Canterbury acknowledged the papal supremacy, and received in return the pallium, the sign of authority and the pledge of submission; and all the enactments concerning transubstantiation, confession, indulgences, and the primacy of the pope, with the condemnation of the Albigenses and Waldenses, were accepted by the English church, whose ambassador was present at the Fourth Lateran Council, which sat in I 2 15, when Magna Charta was signed. All the great orders flourished in England, and the Mendicant Friars, the Franciscans, the Dominicans, the Carmelites-respectively known as Gray, Black, and White Friars-as soon as established migrated thither successively.

For the three hundred years prior to the reign of Henry VIII. England " had been the tamest part of Christendom to the papal authority, and had been accordingly dealt with. But though the Parliaments and two or three high-

1 Macaulay's “ History of England," vol. i., p. 13. 
spirited kings had given some interruptions to the cruel exactions and other illegal proceedings of the court of Rome, yet that court always gained their designs in the end." 1

It was quite common in those days for men who had committed the worst crimes to take orders; for then not only were all past misdeeds condoned, but they could not be arrested for any crime committed after holy orders were given until they had been degraded; in the meantime they were the bishop's prisoners, and protected against the civil law.

As the people, though often worse, are seldom better than the clergy, the terrible impeachment of the former by Wickliffe, in the middle of the fourteenth century, is conclusive as to the general condition.

"They haunt taverns out of measure, and stir up laymen to drunkenness, idleness, and cursed swearing, cheating, and fighting. For they will not follow earnestly in their spiritual office after Christ and his apostles, and therefore they resort to plays at tables, chess, and hazard, and roar in the streets, and sit at the taverns till they have lost their wits, and then chide and strive, and fight sometimes. And sometimes they have neither eye nor tongue nor hand nor foot to help themselves for drunkenness. By this example the ignorant people suppose that drunkenness is no sin; but he that wasteth most of poor men's goods at taverns, making himself and other men drunken, is most praised for nobleness, courtesy, freeness, and worthiness." 2

Henry, second son of Henry VII. and his queen, Elizabeth of York, was born at Greenwich in I49I. In April, I 509, he succeeded his father on the throne, and two months later wedded his brother's widow, Catherine of Aragon.

1 Burnet's " History of the Reformation in England," vol. i., bk. i., p. 9.

2 "A Book about the Clergy," by J. C. Jeaffreson, vol. i., p. 47. 
During his reign changes were made the effects of which upon the civil and ecclesiastical government of England and its dependencies, upon the visible forms of Christianity in every English-speaking country, and upon the laws, institutions, and social and individual life of their peoples, continue to this day.

Until his twenty-ninth year he was devoted to the pope and eager to prove his loyalty to the Roman Catholic Church. The Reformation was progressing rapidly on the Continent, which was speedily plunged into universal war. Cardinal Wolsey attempted the impossible double task of reforming the clergy and suppressing the religious revolution. At this stage arose the controversy between Henry VIII. and the pope concerning his relations to Catherine. His father had had doubts of the legitimacy of the marriage, and a foreign court had made objection to intermarriage with the children of Catherine; yet, as there were no male heirs, the probability of a disputed succession in the event of his death agitated the people of the realm.

In 1527 a demand for a declaration that the marriage was null and void was formally laid before the pope. The temporizing of the pontiff irritated the king, who discarded Wolsey as not being sufficiently zealous. In I 529 a Parliament was convened which took important and far-reaching steps, the end of which was probably not foreseen.

The first formal step, however, toward the separation of Henry VIII. from the Church of Rome was taken in 1531 , the year after the death of Wolsey, when the attorneygeneral filed a bill against the whole body of the clergy, as having been the favorers and abettors of Wolsey in breaking the Act of Præmunire-an act intended to check evasions of existing statutes against those appointed by papal provision to English benefices or dignities. 
The Convocation of the clergy voted a large sum of money to the king, since, if this charge were sustained, the law provided that those who had violated the Act of Præmunire should be out of the king's protection, their goods and chattels, lands and attainments, forfeited to the king, and their persons attached wherever found. Henry, however, refused to accept the money unless words were inserted in the preamble to the effect that he was the protector and head of the church and clergy of England. The latter were alarmed, but after long debate consented to yield so far as to recognize the king in these words: "Chief protector, the only and supreme lord, and as far as the law of Christ will allow, the supreme head of the English church and clergy."

In 1532 Henry VIII. wedded Anne Boleyn, and instantly was published a papal threat of excommunication. Whereupon the English Parliament, at the instigation of the king, passed an act "forbidding appeals from English ecclesiastical courts to Rome," and Archbishop Cranmer declared the marriage of Catherine null and void.

The pope's authority in England was annulled in 1534, and an act declared Henry VIII. supreme head of the church. With the sanction of the Convocation, in 1536 he prescribed the doctrines to be taught in the churches. The Scriptures and the ancient creeds were to be the standards of faith; the traditions or decrees of the church were excluded from authority; the doctrine of justification by faith was clearly expressed; four of the seven sacraments required by the Church of Rome were omitted ; purgatory was spoken of in a doubtful manner; but transubstantiation, confession to priests, and the worship of saints and images were retained.

In 1536 the pope prepared, and two years later published, a bull of deposition, in which he "deprived the king 
of his crown, laid the kingdom under an interdict, declared his issue by Anne Boleyn illegitimate, dissolved all leagues which any Catholic princes had made with him, freed his subjects from all oaths of allegiance, cut off their commerce with foreign states, and declared it lawful for any one to seize them, to make slaves of their persons, and to convert their effects to his own use." 1

But waves of innovation began to roar and beat against the church, until Henry himself was affrighted. In the year 1539, by the aid of influential opposers of the Reformation, he succeeded in securing the passage of a statute by the Commons, approved by the Lords, making it a penal offense to speak against any one of the Six Articles. The first of these affirms transubstantiation; the second that "communion in both kinds, bread and wine," is not necessary to salvation to all; third, that priests after admission to orders are forbidden by the law of God to marry; fourth, that vows of chastity are required by the law of God; fifth, that private masses ought to be continued; sixth, that auricular confession is expedient and necessary, and should be retained. Under this statute, which was enforced for eight years, many were brought to the stake and to prison.

Toward the close of his life Henry VIII. was much dissatisfied, and in proroguing Parliament in person, " after thanking them for their loving attention to him, ... he complained of their dissensions, disputes, and animosities in religion. He told them that the pulpits were become a kind of battery against each other; that one preacher called the other a heretic and Anabaptist, which was retaliated by the opprobrious appellations of papist and hypocrite; that he had permitted to his people the use of the Scrip-

1 Hume's " History of England," vol. iii., p. 213; quoted by Hume from Saunders. 
tures, not to furnish them with materials for disputing and railing, but that he might enable them to inform their consciences and instruct their families; that it grieved his heart to find how that precious gem was prostituted by being introduced into the conversation of every ale-house and tavern, and employed as a pretense for decrying the spiritual and legal pastors; and that he was sorry to observe that the Word of God, while it was the object of so much anxious speculation, had very little influence on their practice; and that though an imaginary knowledge so much abounded, charity was daily going to decay." 1

As his health failed he grew more severe. He promoted the burning of Annie Askew, "a young woman of merit as well as beauty," closely connected with the queen and many of the chief ladies at court, at the same time with three men, one of whom was a priest of his own household, because they did not agree with his views of the real presence; and the queen narrowly escaped the same fate. He spent his declining days in endeavoring to compass the death of the Duke of Norfolk, whose execution had been ordered for the morning of the 28 th of January; but the king died the previous night.

The most favorable estimate of Henry VIII. is given by Hume, who says: "A catalogue of his vices would comprehend many of the worst qualities incident to human nature: violence, cruelty, profusion, rapacity, injustice, obstinacy, arrogance, bigotry, presumption, caprice; but neither was he subject to all these vices in the most extreme degree, nor was he, at intervals, altogether destitute of virtues; he was sincere, open, gallant, liberal, and capable of at least a temporary friendship and attachment." 2

Macaulay comprehends in this passage his view of the

1 Hume's " History of England," vol. iii., p. 298.

2 Ibid., vol. iii., p. 309. 
purposes of the king with regard to the church: "Henry VIII. attempted to constitute an Anglican church differing from the Roman church on the point of supremacy, and on that point alone. .. [ [His character, position, and supporters] enabled him to bid defiance to both the extreme parties; to burn as heretics those who avowed the tenets of Luther, and hang as traitors those who owned the authority of the pope." 1

The apologists of Henry VIII. are reliable witnesses to the general corruption of the age. One says: "He was no hero, no ideal man or king. He shared fully in the coarseness and indelicacy of the age." The reformation accomplished in his reign was superficial, though it contained the germs of something better. The clergy were covetous, given to secular affairs, devoted to pleasures, many indulging in licentiousness which they scarcely took the pains to conceal; and the tendency to immorality pervaded all classes.

When Henry VIII. died, his only son, Edward, whose mother was Jane Seymour, was but ten years of age. Nominally he was king until his death at the age of fifteen and a half, and important measures marked his reign. His uncle, the Earl of Hertford, was named Protector and created Duke of Somerset. In two years his place was taken by Dudley, Earl of Warwick, created Duke of Northumberland, and two years later Somerset was beheaded under charges of treason and felony.

Both these protectors, however, carried on the Reformation. The first Book of Common Prayer was authorized in 1549 , and in 1552 the second appeared, which diverged much more widely from the Roman Catholic doctrine. These were substituted for the missal and breviary. Several bishops rebelled and were deprived of their sees.

1 Macaulay's " History of England," vol. i., p. I5. 
Just before the death of Edward VI. the council required bishops to remove the altars from all parish churches in their dioceses.

While the boy king was suffering from a mortal illness he was induced by the intrigues of the Duke of Northumberland to name Lady Jane Grey as his successor. The cause of this attempt to change the succession was that Mary, the daughter of Henry VIII. and Catherine of Aragon-who had been brought up in the Catholic faith, but after the execution of Queen Anne Boleyn had acknowledged her father as head of the church in England; confessed that her mother's marriage was unlawful ; and yielded an outward conformity to the successive changes in religion during Henry's reign, on account of which she again received her father's favor, and the succession was restored to her by act of Parliament-had, during the reign of her brother, Edward VI., steadily refused conformity to the Protestant religion.

On the death of Edward VI. Lady Jane Grey was actually proclaimed, but Mary entered London in triumph; and though she began by declaring to the people of Suffolk that she would never change the laws of Edward VI., she immediately proceeded to undo his work; put Lady Jane Grey and her husband to death on the charge of treason, liberated the imprisoned Catholic bishops, and shut up Colgate, Archbishop of York, Coverdale, Bishop of Exeter, Ridley of London, Hooper of Gloucester, and Latimer. Mary's wrath even threatened the safety of Elizabeth, her sister.

The mass, though contrary to law, was revived. Cranmer, who protested against the mass, and declared that those who asserted that he approved it made use of his name falsely, was convicted of high treason.

Mary then sent messages to Pope Julius III. informing 
him that she earnestly desired to reconcile herself and her kingdom to him, and asked that Cardinal Pole might be made legate to transact the business.

The Convocation was called at the same time with the Parliament. The Romanists offered to dispute the points controverted between the two communions. "The Protestants pushed the dispute as far as the clamor and noise of their antagonists would permit ; and they fondly imagined that they had obtained some advantage, when, in the course of the debate (on transubstantiation), they obliged the Catholics to see that according to their doctrine Christ had at his last supper held himself in his hand, and had swallowed and eaten himself." 1

In I 554 Mary married Philip II. of Spain, and blended the remorseless, inquisitorial, persecuting cruelty of the Spanish spirit with her own fanatical and bloodthirsty disposition. When Cardinal Pole arrived, invested by the pope with powers as legate, he was presented to the king and queen, and asked the Parliament to reconcile itself and the kingdom to the apostolic see. Both houses, in an address to Philip and Mary, acknowledged that they had been guilty " of the most horrible defection from the true church," and besought their Majesties that, "since they were happily unaffected with that criminal secession, they would intercede with the holy father for the absolution and forgiveness of their penitent subjects." Cardinal Pole, in the name of the pope, absolved both the kingdom and Parliament, offered them every cynosure, and received them into the church.

Cardinal Pole opposed persecution, but Mary and Philip preferred the arguments of Gardiner. Then began scenes which seem to prove that " no human depravity can equal

1 Collier, vol. ii., p. 356; quoted by Hume, " History of England," vol. iii., p. 399 . 
revenge and cruelty covered with the mantle of religion," though the French Revolution subsequently demonstrated that hatred of religion in the names of liberty, equality, and fraternity might perpetrate still darker deeds.

Systematic persecution began with the burning of John Rogers, prebendary of St. Paul's, and followed with the execution of Hooper, Bishop of Gloucester; Saunders, burned at Coventry ; Taylor, parson of Hadley ; Philpot, Archdeacon of Winchester; Farrar, Bishop of St. David's, burned in his own diocese; Ridley, Bishop of London, formerly Bishop of Worcester, burned in the same flames with Latimer at Oxford. The persecuting spirit of Mary became almost a delirium, and a proclamation was issued that whoever had any books of heresy, etc., and did not presently burn them without reading or showing them, should be esteemed rebels, and without further delay executed by martial law.

The persecution of Protestants under Mary developed a higher degree of moral courage than had of late existed in England. The lowest estimate of the number of those who suffered death for adherence to Protestantism in her reign is three hundred. A high Roman Catholic authority acknowledges that " every one knows with how great severity Mary's government proceeded against the Protestants-Cranmer, Ridley, Latimer, and many others being burned, and hundreds forced to flee for their lives to foreign countries." 1 The average morality of the kingdom during her reign sank still lower than it was during the reign of Henry VIII.

Upon the death of Mary, Elizabeth, who had narrowly escaped with her life, and had been kept in close confinement during most of Mary's reign, ascended the throne, being crowned on the I 7 th of November, I558. The

1 “A Catholic Dictionary," by William E. Addis and Thomas Arnold, M.A. 
bishops and higher clergy whom Elizabeth found on her accession were generally stanch Catholics; but Elizabeth was the daughter of Anne Boleyn, and two popes had declared her mother's marriage to Henry VIII. null and void. She was under strong personal temptation to ally herself and her kingdom with Protestantism, and there is reason also to believe that she was sincerely opposed to many of the Romish doctrines.

Men of eminence, ability, and force of character became associated with her, and reconstruction began at once. Cardinal Pole being dead, the Archbishop of York, in his capacity as chancellor, held the seals, and these were at once given to Bacon. As Mary had devoted herself to the reëstablishment of the Roman Catholic faith and worship, so with equal zeal Elizabeth bent her energies to the restoration of the Protestant faith. One of her first acts was to forbid the Bishop of Carlisle to elevate the host while saying mass, thus indicating that she did not accept the dogma of transubstantiation. On this account Archbishop Heath refused to take part in her coronation, and only one bishop was found willing to participate.

In December of the same year she inhibited all preaching "for the present." The bishops, however, were opposed to reformation. The court secured a Parliament which repealed the persecuting laws of Mary and gave the queen all power to regulate doctrine, discipline, worship, to appoint all bishops, and "to establish high commission courts with powers nearly equal to the inquisition." The second Prayer-book of Edward VI. was restored. Parliament having adopted Protestantism as the religion of England, every bishop, with one exception, seceded therefrom and refused the oath. That one, Kitchen, Bishop of Landaff, was an idle abbot under Henry VIII., Protestant under Edward, returned to Romanism under Mary, and 
took the oath of supremacy under Elizabeth, and finished as a Parliament Protestant. Isaac Disraeli, in " Curiosities of Literature," writes that " a pun spread the contumely of his name; for they said that he had always loved the Kitchen better than the church."

It was during these changes that the proverb "the Vicar of Bray will be Vicar of Bray still" originated. For the vicar referred to was a papist in the time of Henry VIII., Protestant under Edward VI., again papist under Mary, and finally a Protestant under Elizabeth. According to Fuller, when he was accused of being an inconstant changeling, he said: "Not so neither; for if I changed my religion I am sure I kept true to my principle, which is to live and die the Vicar of Bray."

The Convocation of 1563 adopted the Thirty-nine Articles, which had been prepared in the latter part of the reign of Edward VI. They distinguish the doctrines of the Church of England from those of the Roman Catholic communion by introducing the Lutheran doctrine of justification by faith alone, denying purgatory and reducing the sacraments from seven to two, and by affirming many anti-Roman principles. The pope issued a bull deposing Elizabeth. For a while Catholics who did not leave the country went to church with Protestants, taking pains not to enter or leave the building with them, expecting that the authority of the pope would be restored ; but the Council of Trent decided such attendance at Protestant worship to be sinful.

About half of the cathedral clergy, archdeacons, and heads of colleges refused the oath. All such were expelled, and the Protestants ejected under Mary were recalled to fill the vacant positions. Matthew Parker, formerly a Catholic priest, who in the time of Mary had married and thus been compelled to go into obscurity, was now made 
Archbishop of Canterbury. Elizabeth appointed bishops who would favor the Reformation, and summoned to consecrate them the ex-bishops who had been removed by Mary. All the clergy of England, except about two hundred, obeyed the fifty-two injunctions that Elizabeth issued regulating devotion, discipline, holy days, and clerical duties.

During her reign Elizabeth was constantly in conflict with the adherents of the Romish system, and as the Puritan party was continually growing stronger, she was bitterly opposed to and by them. Professor Reid, of Glasgow, observes concerning this phase of Elizabeth's character that she was "fond of splendid worship, and . . r rigorously enforced uniformity. Thus the Reformation was arrested, and the Established Church has remained substantially the same as in the year I562." 1

The personal character and moral influence of the.reign of Elizabeth have been much debated. Protestants have praised, Romanists condemned her. A judicious critic observes that recent inquiries have resulted in a less favorable view than has prevailed in England. Shakespeare, Bacon, and Spencer flourished in her reign, which was also marked by great enterprises and discoveries; but under various acts one hundred and twenty-eight priests and members of religious orders, fifty-eight laymen, and three women were put to death. Such a succession of terrible deeds, including the execution of Mary, Queen of Scots, and an attachment to the unworthy Earls of Leicester and Essex, together with the natural tendency of such transitions, was compatible with only a slight elevation, if any, in the conduct and spirit of the people.

James I. of Scotland, a character who has been the puz-

1 " Mosheim's Institutes of Ecclesiastical History," by James Murdock, D.D. ; revised and supplemental notes added by James Seaton Reid, D.D. 
zle of historians, succeeded Elizabeth. He was educated among the Presbyterians, and from the General Assembly in 1590-where he thanked God that he was king of the sincerest kirk in the world, and thus addressed the members: "I charge you, my ministers, doctors, elders, nobles, gentlemen, and barons, to stand to your purity and to exhort your people to do the same, and I forsooth as long as I brook my life shall do the same"-down to his removal to England in 1603 , he declared himself conscientiously attached to that church.

When he began his journey all religious parties in England paid court to him; the Dutch and French Protestants settled in the country waited upon him, the bishops sent their envoys, the Universities of Oxford and Cambridge appealed to him in behalf of the Establishment, and the Puritans sent him a petition signed by eight hundred of their ministers.

The same year a conference was held between the Episcopalians and the Puritans. According to Neal, the former were allowed to select nine bishops and as many dignitaries of the church; on the part of the Puritans the king selected one Scotch and four English divines. It proved a mock conference, in which the king went over entirely to the Established Church. The explanation given by Mosheim is this: "King James, who was eager to grasp supreme and unlimited power, at once judged that the Presbyterian form of church government was adverse to his designs, and the Episcopal favorable to them; because Presbyterian churches form a kind of republic, which is subject to a number of leading men all possessing equal rank and power, while Episcopal churches more nearly resemble a monarchy. The very name of a republic, synod, or council was odious to the king, and he therefore studied most earnestly to increase the power of the bishops, and publicly declared 
that without bishops the throne could not be safe." 1 But for a long time he did what he could to preserve the Genevan doctrines.

With a majority of the clergy he afterward inclined to the Arminian doctrine concerning decrees, and before his death had become a mortal enemy of the Puritan faith. In some respects he strengthened the cause of Protestantism, especially by the preparation and authorization of the translation of the Bible; but his reign promoted neither piety nor morality.

He executed Sir Walter Raleigh under circumstances which proved him destitute of the elements of true nobility. The longer he lived the more violent became his contests with Parliament. He was superstitious; in minor matters of morals, self-opinionated and autocratic, and in great questions lacked breadth and dignity; and his career closed in open hostility to the Presbyterians and with the country upon the verge of civil war.

Macaulay's estimate of the character and reign of Charles I. is discriminating: "He had received from nature a far better understanding, far stronger will, and a far keener and firmer temper than his father's. . . . It would be unjust to deny that Charles had some of the qualities of a good, and even of a great prince. . . . His taste in literature and art was excellent, his manner dignified though not gracious, his domestic life without blemish. Faithlessness was the chief cause of his disasters, and is the chief stain on his memory. $\mathrm{He}$ was, in truth, impelled by an incurable propensity to dark and crooked ways. . . There is reason to believe that he was perfidious, not only from constitution and from habit, but also on principle. $\mathrm{He}$ seems to have learned from the theologians whom he most esteemed that between him and his subjects there could be nothing of the nature

1 "Mosheim's Institutes of Ecclesiastical History," seventh edition, p. 820. 
of mutual contract; . . . and that in every promise which he made there was an implied reservation that such promise might be broken in case of necessity, and that of the necessity he was the sole judge." 1

The Commons, not sympathizing with his efforts to extend the regal power and make it superior to the laws, to subject the whole church of Great Britain and Ireland to an episcopal form of government, or to reject the institutions and doctrines of the followers of Calvin, determined to place the king in a position where he would be obliged to submit to their wishes or attack fundamental principles of the British constitution. Religiously he was a zealous Episcopalian and a decided Arminian, and "though no papist, he liked a papist much better than a Puritan."

The proceedings of Laud, to whom the execution of the designs of Charles was intrusted, as Bishop of London, and subsequently as Archbishop of Canterbury, though characterized by ability, were fierce, headlong, and inconsiderate.

The king soon decided to defy the law. He prorogued the first Parliament and on his own authority levied taxes, convoked a second Parliament and dissolved it, threw his chief opponents into prison, billeted soldiers on the people, and substituted martial for civil law. The third Parliament proving more obstinate than its predecessors, he temporized by making promises which he subsequently disregarded - as he intended to do when he made them-and attempted to make himself a despot by reducing the Parliament to a nullity. From March, I629, to April, I640, England was without a Parliament. In 1644-45 Laud was impeached by the Commons, tried by the Lords, found guilty, and beheaded. This Parliament, principally under the control of Presbyterians and Independents, abolished the form of church government by bishops, and repealed

1 Macaulay's "History of England," vol. i., p. 24. 
whatever was contrary to the principles of the Calvinists as represented by the Genevans.

After the brave attempt of John Hampden to stand for personal liberty by refusing to pay the illegal shipping tax, the best men began to flee the kingdom. During the war with Scotland the two parties-those inclined to limit the power of the crown more and more, and those " ready to lay all the laws and franchises at the feet of the kings"appeared in a distinct form, though, as is always the case, the majority of each were more or less conservative, while the enthusiasts and extremists were most conspicuous. On the king's side were the larger number of the nobles, all the opulent citizens with their dependents, the great body of the clergy, and the Unionists, all laymen of the Anglican faith. These had allies "much less decorous than themselves. The Puritan austerity drove to the king's faction all who made pleasure their business, who affected gallantry, splendor of dress, or taste in the lighter arts," and those who lived by amusing, "from the painter and comic poet down to the rope-dancer and the merry-andrew."

The English Roman Catholics to a man espoused the king's side. In defending this the Catholic writers declare that they had no alternative; they could expect some justice from the king, but none from the Parliament. The wife of Charles was a daughter of France, and of their own faith.

The opposition consisted of the small farmers, merchants, and shop-keepers, a powerful minority of the aristocracy - such as the Earls of Northumberland, Bedford, Warwick, and Essex-the whole body of Protestant nonconformists, those members of the Established Church who were Calvinists, and most of the municipal corporations.

Upon a fair view of Catholic, Protestant, and critical history of the time it is impossible to believe that the reign 
of Charles I. promoted either religion or morality. Although the first Presbyterian church was established in England in 1572, the majority of the English clergy who inclined to Presbyterian views did not withdraw from the Established Church, but were distinguished by the general title of Puritans. Persecution drove many of them to the New World and to various parts of Europe; yet the party greatly increased during the reigns of James I. and Charles I.

Episcopacy was abolished in I642, and a year later the famous Westminster Assembly was convened by Parliament, which commanded one hundred and twenty-one of the ablest theologians, with thirty lay assessors, to assist it in settling the principles, ritual, and government of the Church of England. The majority were Presbyterians; there were a few Episcopalians, some Independents, and four commissioners from the General Assembly of the Scottish church, asking the Westminster Assembly and Parliament to make a solemn league and covenant to establish a uniform religion throughout the three kingdoms.

Within two years serious differences arose between the Assembly and Parliament. The English Presbyterians proposed to establish Presbyterianism throughout England, with no toleration of dissenters. Supported by the weight of the Scottish nation, they sent petitions in the name of the lord mayor, aldermen, and Common Council of London. This divided the Commons, as the Independents and other dissenters sent up counter-petitions; and the debate in the Assembly waxed so hot that the Independents and others withdrew. Extraordinary resolutions followed, and the country divided into sects, of which Edwards, a contemporary author, mentions fifteen: Independents, Brownists, Millinaries, Antinomians, Anabaptists, Libertines, Familists, Enthusiasts, Seekers, Perfectionists, So- 
cinians, Arians, anti-Trinitarians, anti-Scripturists, and Skeptics.

Notwithstanding that Charles I. was a prisoner, he refused to consent to the proposed new forms of government. Parliament fell under the control of the army, consisting principally of dissenters, who took active part in the discussions, and allowed dissent from the then established religion, Presbyterianism. But when the Scots invaded England to rescue Charles I., the army having to divide and march in different directions, the Presbyterians seized the opportunity to enforce their doctrines and usages. Finally Parliament impeached and executed the king, but not until he had reduced the government to a despotism.

Oliver Cromwell during the Protectorate offered free toleration to all sects except papists and Episcopalians, but forbade the clergy to meddle with politics. For some years the right of ordaining parish ministers had been exclusively possessed by the Presbyterians. Cromwell appointed a board of "thirty triers," composed of Presbyterians and Independents and two or three Baptists, to examine and license preachers throughout England, and lay commissioners in every county "with full power to check scandalous, impudent, and incompetent ministers and schoolmasters"; and Parliament confirmed these ordinances.

When Cromwell died and his son Richard came into power, the Presbyterians had relinquished the hope of obtaining ecclesiastical dominion over England under that form of government. They therefore, in 1659 , formed an alliance with the Royalists to restore the king, who was quite ready to negotiate satisfactorily to the Parliament. The Presbyterians were as strenuously opposed to the views of the republicans as to the ascendancy of Episcopal forms. Charles II. ascended the throne unfettered by any 
stipulation concerning religion, and speedily established Episcopacy without toleration to dissenters. In I662 the Act of Uniformity was passed, making it criminal to dissent from the Established Episcopal Church. A few Presbyterian clergymen conformed, but more than two thousand, most of whom were Presbyterians, were expelled.

Charles II. was incapable of ruling wisely or justly. The influence of his reign was evil. He lacked genuine ambition, was essentially frivolous, indolent, impatient, and without conscience, vacillating between infidelity and popery. Morality had so degenerated that " poetry stooped to be the panderer of every low desire; ridicule, instead of putting guilt and error to the blush, turned her formidable shafts against innocence and truth."

Joseph Jefferson, in discussing the influence of the plays of Shakespeare, says that "with the exception of one shameful hiatus in the time of Charles I. and Charles II., Shakespeare has always held the supremacy among Englishspeaking peoples. But he was too polite for those times. A foul court had forced upon the people dramas so terrible and so degraded that ladies went to the play wearing masks. The stain of those dramas has never utterly been wiped out, and it remains on the stage to this day." The church contended against it but feebly. The most corrupt of the people were politicians, but "scarcely any rank or profession," says Macaulay, "escaped the infection of the prevailing immorality."

Before the inconsistent career of Charles II. was closed by death he rejected the offices of the Church of England, confessed to a Roman Catholic priest, and received extreme unction and the Lord's Supper.

In the thirty-third year of his age James II. avowed his conversion to Romanism. A few years later attempts 
were made to secure his exclusion from the succession, and he was ordered to quit the kingdom. To prevent the passage of such a bill Parliament was dissolved in 1680; but although twice "presented" as a popish recusant, in I 685 he ascended the throne. During his reign he aimed to restore the Roman Catholic religion, and to prevent Parliament from restricting either his despotic spirit or the constitution. Endeavoring meanwhile to cajole his subjects by a declaration in favor of liberty of conscience, he filled his army and council with Roman Catholics, but could not thereby deceive the dissenters. His constant innovations in religion and government finally united the people against him, and they invited the Prince of Orange to take the throne. When James, who had been ignorant of their purposes, heard of the invitation to William, he was terrified, repealed his obnoxious acts, and courted popularity; but it was then too late.

It is a singular fact in the history of those times that the Quakers, who came into existence as a community in the reign of Charles I., and the supporters of royalty among the Anglican clergy, reached from totally different premises the same conclusion - that no act of tyranny on the part of a prince can justify active resistance on the part of a subject. James II. had procured the enactment of laws ex- pressly designed to " harry Puritans," but he found no fault with the Quakers; for, taking no part in civil affairs, they neither talked politics nor engaged in conspiracies. Making William Penn his familiar friend, he was very indulgent to them, "the only redeeming quality in his career as king."

Even the Roman Catholics, whose cause he espoused, have little to say in his favor. They declare that his zeal was not according to knowledge; " moreover, the scandalous immorality of his private life damaged his advocacy; 
Episcopal Protestants could not be blamed for regarding with distrust the efforts of the married lover of Catherine Sedley to advance the interests of his religion by overriding the civil laws." 1

William, who was a Calvinist, contributed to the enactment and enforcement of penal laws against the Roman Catholics. Papists, and those reputed to be such, were forbidden to live within ten miles of Westminster, and a horse worth more than five pounds belonging to any papist could be seized. The Toleration Act provided that nothing in the act could be construed to give "ease, benefit, or advantage to any papist." The Bill of Rights declared that no papist, or any one that married a papist, should inherit the crown. A reward of a hundred pounds was offered for information leading to the conviction of a Catholic priest for saying mass or keeping school; such priest would be imprisoned for life.

The occasion for these persecuting statutes was that in every department of the public service Roman Catholics " had much more than ten times as great an amount of patronage as they would have had under an impartial system." They had been made rulers of the Church of England, and yet the laws against popery were unrepealed.

The moral influence of William and Mary was better than that of most of their predecessors. Her character was remarkably fine, and his courage, decision, conscientiousness, and adherence to purpose were admirable; but his unpopularity with his subjects, growing in part out of his foreign origin and sympathies, and from the exercise of his qualities in connection with religious controversies, counteracted their effect. Dissensions were accentuated by the fact that the primate Sancroft and seven of the bishops refused to take oaths of allegiance to the new government, on ac-

1 "A Catholic Dictionary," by William E. Addis and Thomas Arnold, M.A. 
count of which they were suspended, and afterward those who survived deprived. Some of the clergy followed their example, being known with them as nonjurors.

Political corruption was so common that though the conscience of William was strongly opposed to it and he resolved to abstain from it, and during the first year of his reign did so, he yielded to the sophism that "those who receive the filthy lucre are corrupt already; he who bribes them does not make them wicked; he finds them so, and he merely prevents evil propensities from producing evil effects." Burnet remonstrated with him. The king responded: "Nobody hates bribery more than I; but I have to do with a set of men who must be managed in this way or not at all ; I must strain a point or the country is lost."

On the death of William, in I702, Anne, daughter of James II., ascended the throne. In her time public and private morality were at a lower ebb than before, though the spirit of the people was less sanguinary than in periods not remote. From the "Tatler," the "Spectator," and the "Guardian" the general condition of manners and morals can be inferred. It was a time of double dealing in politicians and even statesmen of all parties, and of rancor and duplicity in ecclesiastics in the way of preferment in the Church of England, and of those who sought power by manipulating dissenters and nonconformists. It was also a period in which the reflex influence of war added to the prevalent demoralization, and questions of the succession and of the union of England and Scotland diminished the courage and stimulated the subtlety of the ambitious.

Superstition was revived, for Queen Anne brought back the ceremony of "touching for the king's evil," which William III. had sufficient sense to reject; and the belief in witchcraft and omens was general. Drunkenness and reveling greatly increased, and a low estimate of woman 
characterized both sexes. "Prudes" and "coquettes" were the least objectionable characters represented upon the stage, which had not recovered from the degradation of the time of the Stuarts.

The spirit of gambling was universally diffused, and, with few exceptions, the high and the low exhibited an almost total lack of refinement. The queen herself was not, even on her better side, a positive moral force, and the "good nature and generosity which procured her the name of the 'good Queen Anne' seem to have sprung as much from the indolence of her temper and the weakness of her understanding as from any active principle of benevolence." 1

It would appear that from the time of Henry VIII. everything relating to religion-except morals-had received attention. The austerity of the Puritan party produced reactions, and unquestionably tended to hypocrisy in those whose interests required them to remain in connection with the Parliament party, and who found its rigorous discipline an intolerable burden. The mass of the people, transferred from one religious system to another with no option of their own, were either submissive or indifferent. The divergence of views concerning the proper observance of Sunday promoted general disregard of the day. Dissenters of different sects knew little of toleration, less of fraternity; and while signal examples of piety and learning were found in the Established Church and among the older sects, cant and formality characterized the majority. Controversy could be enkindled in a moment, speedily became tinged with bitterness, and hurried on to violence. The greatest extremes of doctrine, discipline, and ritual were advocated with vehemence, while to gain a temporary ascendancy apparently destructive compromises were made, only to smother temporarily the flames 1 “Student's Hume" (London, John Murray, I862). 
which raged beneath. The spiritually minded and all of keen sensibility deplored the condition of social and ecclesiastical morals.

The connection between public and private morality is so intimate that it is a safe generalization that neither exists long alone. As respects many external things the reformation had been considerable; but as regards the purpose for which Christianity was founded, and to which forms and discipline are but means, and in all but a few essentials subordinate, it was superficial. 


\section{CHAPTER II.}

\section{PROGENITORS OF THE FOUNDER.}

ONE of the most recent lives of Wesley ${ }^{1}$ represents that he "was of gentle birth on both sides. The Wesleys were an ancient family settled in the west of England from the time of the Conquest. The Annesleys, his mother's family, were an equally ancient and respected stock."

George J. Stevenson, ${ }^{2}$ M.A., of London, traces the ancestors of Wesley, through the genealogical table prepared about a century ago by the descendants of the Earl of Mornington, in both England and Ireland, to a very early period, under the three names of Wesley, Westley, and Wellesley; identifying one branch of the family down to Arthur, Duke of Wellington, and another to Herbert, the only son of Walter Wesley, who received the honor of knighthood and was contemporary with Queen Elizabeth. He wedded Elizabeth, daughter of Robert Wesley, of Dangan Castle, Ireland, by which the English and Irish branches of the family were reunited. To them were born three sons: William, heir of the estates and contemporary with James I. ; Harphame, who died unmarried ; and Bartholomew, who was ordained a priest.

Concerning this genealogical tree the Epworth Wesleys do not appear to have known or cared much, for John Wesley declared when in middle life that all he or his fam-

1 "John Wesley," by J. H. Overton, rector of Epworth.

2 "The Wesley Family." 
ily knew of their ancestry went no further back " than a letter which his grandfather's father had written to her he was to marry." That letter was dated I6I9, so that Bartholomew Wesley was then single, Following John Wesley and his father, Samuel, most biographers begin with Bartholomew Wesley. Thus Southey (chapter i., American edition) says: "The founder of Methodism was emphatically of a good family, in the sense in which he himself would have used the term." Whitehead and Coke begin at the same point; "The Life and Times of Samuel Wesley" represents Bartholomew Wesley as born about the year I600; Stevenson puts it in the year 1595; and all accounts agree that he was born in Dorsetshire.

A comparison of dates makes clear that Puritanism was rapidly spreading in the national church during the period of the childhood and youth of Bartholomew Wesley, who was educated at the University of Oxford, where he pursued the study of physic and divinity. The maiden to whom was written the letter of which John Wesley speaks was the daughter of Sir Henry Colley, of Kildare, Ireland. Little is told of his family or personal history after his marriage until I640, when he was installed rector of Catherston, in his native county. He was born in the last days of the reign of Elizabeth, and before his installation passed through the reigns of James I. and Charles I., being about thirty years of age when the latter ascended the throne. The political and ecclesiastical subjects discussed and the state of his mind during the formative period can easily be inferred from contemporary history.

Ten years after his induction into the rectory of Catherston that of Charmouth was added, the two villages being about a mile apart. The trial and judicial beheading of Charles I. took place while he was in his prime, and he held these rectories during all the wars of the Common- 
wealth, the career of Oliver Cromwell as Protector, the brief period during which his son Richard reigned, and the first two years of the reign of Charles II., when, being strenuously opposed to the latter's dissolute life, perfidious character, and popish tendencies, he was one of the two thousand ministers ejected in 1662 under the Act of Uniformity.

Bartholomew Wesley continued to live in Charmouth for many years, preaching when he could, and administering medicine when occasion demanded. Throughout that western region dissenting Christians were persecuted in every possible way and were compelled to worship God secretly. In I664 one of his neighbors wrote of him: "This Wesley of Charmouth, now a nonconformist, lives by the practice of physic in that place." In a book published the same year the author calls Wesley "the puny parson of the place, and a most devoted friend to the parricides." Concerning this epithet Stevenson remarks: "All the Wesleys for three hundred years were of small stature, ranging from five feet four to five feet six inches."

Bartholomew Wesley had but one son, John, born in Devonshire in 1636 . Like his father, he was educated at Oxford, where his proficiency was marked; and at the age of twenty-two he had taken his degree of master of arts. Dr. John Owen, chaplain to Oliver Cromwell, was vice-chancellor at the university, and, observing that John Wesley was of a serious turn and attentive to his studies, gave him sympathy and assistance. Proficient in every department, he applied himself especially to the study of the oriental languages. It is probable that he was at Oxford during the entire time of Dr. Owen's administration. Oxford had suffered much from a long siege, and was compared to Jerusalem in ruins. Colleges had been turned into barracks, and halls into granaries. 
"There was little or no education of youth; poverty, desolation, and plunder-the sad effects of war-were to be seen in every corner." The most learned men among the Puritans were then there, and among the students were William Penn, Dr. South, Sir Christopher Wren, and Whitby the commentator.

Previous to his induction into the ministry John Wesley was obliged to pass an examination before Oliver Cromwell's triers, was installed four months before Cromwell died, and married the daughter of John White, one of the members of the Westminster Assembly. During the civil war he took up the sword for the party represented by a Committee of Safety based upon seven principles: that there should be no king, and no single person as chief magistrate; the army should be continued; there should be no imposition upon conscience, no house of peers; that the legislative and executive powers should be in distinct hands; and that Parliament should be elected by the people. When the wars were over and Charles ascended the throne in I660, John Wesley submitted, taking the oath of allegiance.

He was, however, brought before the Bishop of Bristol on a charge that he would not read the liturgy. Their dialogue occupies six pages of Tyerman's "Life of Wesley," and the similarity between the terseness of the founder of Methodism and that of his grandfather is extraordinary.

" What is your name?"

" 'John Wesley.'

" "By whom were you ordained, or are you ordained?"

" 'I am sent to preach the gospel.'

" "By whom were you sent?'

" 'By a church of Jesus Christ.'

"'What church is that?'

"“'The church of Christ at Melcombe.' 
" 'That factious and heretical church?'

" " May it please you, sir, I know of no faction or heresy that that church is guilty of. :. .'

" Did you not ride with your sword in the time of the Committee of Safety, and engage with them?'

" Whatever imprudence in civil matters you may be informed I am guilty of, I shall crave leave to acquaint your lordship that his Majesty having pardoned them fully, and I having suffered on account of them since the pardon, I shall put in no other plea, and waive any other answer. .. .'

" They would approve any that would come to them and close with them. I know they approved those who could not read twelve lines of English.'

" All that they did I know not; but I was examined touching gifts and graces.'

" 'I question not your gifts, Mr. Wesley. I will do you any good I can; but you will not long be suffered to preach unless you do it according to order.'

" 'I shall submit to any trial you shall please to make. I shall present your lordship with a confession of my faith, or take what other way you please to insist on.'

" "No; we are not come to that yet.'

" 'I shall desire several things may be laid together, which I look on as justifying my preaching: (I) I was devoted to the service from my infancy. (2) I was educated thereto, at school and in the university.'

" "What university were you of ?'

" 'Oxon.'

" "What house?'

" ' New Inn Hall.'

"'What age are you?'

" 'Twenty-five.'

“'No, sure, you are not!' 
" '(3) As a son of the prophets, after I had taken my degrees, I preached in the country, being approved of by judicious, able Christians, ministers and others. (4) It pleased God to seal my labor with success, in the apparent conversion of several souls.' "

This examination shows that John Wesley had not been episcopally ordained; that he was a man of gifts; was set apart by the church; that he set aside the liturgy; that he was a man of courage; that, like Paul before Agrippa, he made upon his judge a favorable impression as to his sincerity, piety, and usefulness; and that the bishop was disposed to be fair-minded.

This was not the end of his troubles. Toward the close of the year the Convocation revised the Prayer-book, and in August, I662, the use of it was made binding. There were acts by which John Wesley might have been expelled, but for reasons not ascertained his opponents in the parish took other means of securing his ejection. Two years after Charles II. was restored Mr. Wesley was committed to jail on the charge of refusing to use the Prayer-book. It was a superstitious age, and after Wesley had been in prison for some time, Sir Girrard Napper, who had been the most forward in committing him, broke his collar-bone, and fearing that this might be a judgment for his cruelty to the minister, he took measures to have him bailed. The privy council finally ordered that he should be discharged, provided he would take the oaths of supremacy and allegiance. For that purpose he was brought before a magistrate, who for some reason unknown refused to administer the oaths, and issued a warrant commanding him to appear before the judges at the next assize, two days later.

He could make little preparation, but a solicitor appeared for him. In his diary there is an account of his examina- 


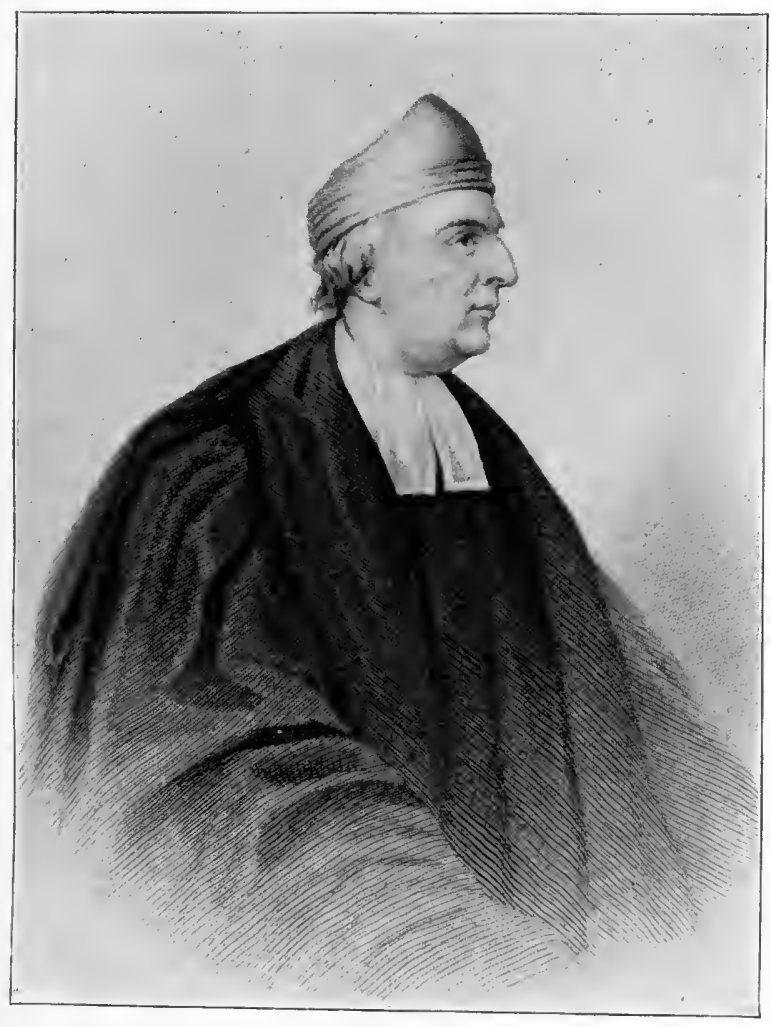

Semíurstry. 

tion and an ascription of praise to God because the aforesaid solicitor pleaded for him, "and the judge, though a man of sharp temper, spoke not an angry word." After an explanation as to why he was not ready, and inquiries by the Bishop of Bristol concerning his former examination, he was questioned as to his legal right to preach.

While the judge was consulting the Act another case was called, and John Wesley was bound over to the next term. He continued to preach until just before he was expelled from church and rectory, with a multitude of others, after the Act of Uniformity. He then delivered a farewell sermon from Acts xx. 32: "And now, brethren, I commend you to God, and the word of his grace."

Although John Wesley was the father of a numerous family, for more than a century the names of but two children were known; recently the names of five and the dates of the birth of the first four have been ascertained, Samuel being the fourth, born December 16, 1662. As the Act of Uniformity went into effect on the 24th of August, Samuel Wesley was born four months after his parents were made homeless, and when he was but nine weeks old they removed to Melcombe; but Sir Girrard Napper and seven other magistrates had control, and induced the corporation to make an order against their settlement in the town. To enforce this a fine of two pounds was to be levied upon the owner of any house in which they might be permitted to live, and five shillings per week upon themselves. Driven out by these violent proceedings, he and his family became wanderers, going from place to place, " in all of which the Presbyterians, Independents, and Baptists treated him with great kindness, and where he preached almost every day." 1

Joseph Alleine, author of that awakening and judicious

1 Tyerman's "Life and Times of Samuel Wesley, M.A." 
work, "An Alarm to Unawakened Sinners," which appeared in 1672 and is republished to this day, was imprisoned, in the heat of the hottest summer, with fifty Quakers, seventeen Baptists, and thirteen other ministers, in one room, "the ceiling so low that at night, when lying on their mattresses, the prisoners could touch the glowing tiles;" and John Wesley narrowly escaped the same fate.

A friend at length offered him a house in Preston rent free, where he dwelt, with the exception of a brief absence, until his death.

While residing at Preston he endeavored to preach regularly; but owing to the Oxford Five Mile Act, though very prudent, he was often disturbed and four times imprisoned, once for three months and once for half a year. According to Stevenson he died in Preston, and is said to have been secretly buried by night, as the Royalist party, then in power, refused his body a place in the churchyard where he had so long ministered. The general belief is that he was forty-two years of age; but from Dr. Callamy's description, written about I yo3, he died "when he had not been much longer an inhabitant here below than his blessed Master was." Accepting the latter assumption, his son Samuel was sixteen years of age when his father died. His widow survived him more than thirty years.

Bartholomew Wesley was still living, but, as Southey remarks, "the loss of this his only son brought his gray hairs in sorrow to the grave." 1

Samuel Wesley's mother, the wife of John, was the youngest daughter of John White, a Puritan divine of great learning, a perpetual fellow of New College, Oxford, and a frequent preacher there. He was prosecuted in 1630 by Archbishop Laud for preaching against Arminianism and the ceremonies of the Established Church; thirteen years

1 Southey, vol. i., p. 54, American edition. 
afterward he was chosen one of the Westminster Assembly, of which he was one of the three assessors, and was for many years rector of Trinity Church, Dorchester. In 1624 he and some of his friends projected the new colony of Massachusetts in New England, and, after surmounting numerous obstacles, secured a patent. The object was to provide an asylum for the persecuted fugitives who were not able to conform to the ceremonies and discipline of the Church of England. In defense of the project he wrote "The Planter's Plea," published in London in 1630, a work of the highest authority, referred to at length in the Massachusetts Historical Society's collections and Young's "Chronicle of Massachusetts." Dorchester, Mass., was given its name from the fact that this John White was rector of Trinity Church in Dorchester, England. Some writers represent him as having arrived there with the colony, but Edward Everett, in his "Dorchester in I630, I 776, and 1855," 1 writes: "Like Robinson in reference to Plymouth, John White never set foot upon the soil of Massachusetts, but he was the most efficient promoter of the undertaking which resulted in the settlement not merely of our ancient town, but of the colony."

He suffered in the civil wars, his house being robbed by a cavalry company under the command of Prince Rupert, who, doubtless thinking to paralyze him, stole his library. His daughter, the mother of John Wesley, was also the niece of the famous Dr. Thomas Fuller, who describes the Rev. John White as "grave without being morose," and as having " in the course of his long ministry expounded the Scriptures all over and half through again, and was so much beloved by his people that he could wind them up to what height he pleased."

In view of the honest poverty of his father, it is not re-

1 Everett's "Orations and Speeches," vol. iii., p. 306, edition of 1858 . 
markable that Samuel Wesley's early education was obtained at the free school in Dorchester. He remembered his master, Mr. Henry Dolling, with such respect that to him was dedicated his first book. Here he continued until he was fifteen, when he was sent to school in London, arriving the year that the popish plot of Titus Oates was exposed. Oates had been one of Cromwell's chaplains, then took orders in the Church of England, was twice convicted of perjury while still holding his office, became chaplain on board a man-of-war, but was dismissed for various iniquities, and went into the service of the Duke of Norfolk, who was a Roman Catholic, became one himself, and entered a Jesuit college in Spain, was expelled, and afterward cast out of a similar college in France, and finally returned to England thoroughly disgraced. He then professed to reveal a frightful plot, said to have been concocted by the procurement of the pope, to murder the king and his brother James, the Duke of York.

Awful events followed. Godfrey, who took Oates's depositions, was murdered. He was esteemed a Protestant martyr, and followed to the grave by a long procession headed by seventy Protestant clergymen in full canonicals. Oates was summoned before Parliament. All classes of Protestants felt their lives to be in danger. Leading Roman Catholics were committed to the Tower, and ordinary prisons filled with them. Men of that faith were expelled from their seats in both houses of Parliament, and a number executed.

A reaction, however, took place. Oates was whipped through the streets of London, thrown into prison for a season, brought out again, and it is claimed by an eye-witness who counted them that he "received seventeen hundred stripes in one day." When set free he resumed the place which he had held among the Baptists, who were 
obliged to reject him. Meanwhile wars were raging in Scotland. A few years later Lord Russell was executed and Algernon Sidney was condemned on Tower Hill.

Samuel Wesley was in London at this time and witnessed all these scenes. He pursued his studies first in a grammar-school, then in the academy at Stepney. In the former he advanced so rapidly that the master desired to send him direct to the university, and promised him support; but a certain dissenting congregation, out of respect for his father, offered him thirty pounds a year if he would go to the academy of the Rev. Edward Veal, who had studied at Christ Church College, Oxford, and Trinity College, Dublin, and bore the highest reputation for learning and piety. Here he remained two years, so progressing as to receive an additional bonus of ten pounds per annum. The school was broken up by the persecutions of the neighboring magistrates, and he went to an academy at Newington Green, taught by Charles Morton, who was also persecuted, and while Samuel Wesley was a student there was obliged to leave the school and conceal himself. Removing to this country, he became vice-president of Harvard College.

Samuel Wesley long afterward thus extolled him: "Mr. Morton was an ingenious and universally learned man; but his chief excellency lay in mathematics. He had many gentlemen of estate, who paid him well; but he thought more of the glory of God than of his private profit."

The students of that school had a mortal antipathy to the Episcopal order, and justified the doctrines that had led to the judicial killing of Charles I. Many of them were opposed to the monarchy, and those "who composed the bitterest and most ill-mannered sarcasms on the public prayers and liturgy of the church were caressed, hugged, encouraged, and commended by the heads of the 
dissenting party, Wesley himself sharing in the applause awarded." 1

It was at this period that he wrote numerous lampoons, principally directed against the clergy of the Church of England and its dignitaries, some of which were scurrilous. His first book was entitled "Maggots," and several of the poems are low in thought and expression, though all display marked talents.

Years afterward Samuel Wesley, while highly commending Mr. Morton for cautioning the students against writing scandalous libels, says that "some of the gravest, oldest, and most learned of dissenting ministers encouraged and pushed me on in my silly lampoons both on church and state, gave me subjects, and furnished me with matter."

While in London Samuel Wesley had the opportunity of hearing Isaac Barrow, John Bunyan, and Stephen Charnock, and others of similar rank; and before he left London for the university " had taken down hundreds of their sermons." 2

In August, I680, possessing but forty-five shillings, he walked from London to Oxford, and entered himself as a student in Exeter College. The entries in his own handwriting spell the name Westley. The evidence of energy and determination of character afforded by this step is conclusive. He had no friends upon whom he could rely. His mother, after years of persecution and suffering, had been left penniless, and was now aged and helpless. The same year, before starting for Exeter, he left the dissenters and lost their friendship. His own reasons are thus given by his son, John Wesley: "Some severe invectives being written against the dissenters, Mr. Samuel Wesley,

1 Tyerman's " Life and Times of Samuel Wesley," p. 69.

2 Ibid., p. 76. 
being a young man of considerable talents, was pitched upon to answer them. This set him on a course of reading, which soon produced an effect different from what had been intended. Instead of writing the wished-for answer he himself conceived he saw reason to change his opinions, and actually formed a resolution to renounce the dissenters and attach himself to the Established Church."

$\mathrm{He}$ resided at that time with his mother and an aged aunt, both of whom were too strongly attached to the dissenting doctrines to bear with any patience the disclosure of his change of views. He therefore arose one morning before daybreak, and, without acquainting any one with his purpose, set out for Oxford, to enter Exeter College; subsequently he implored the divine direction, " examined things over and over as calmly and impassionately as possible," and, speaking of himself, writes: "The mist cleared up, things appeared in another sort of light than I had seen them in all my life before." He gives a minute account of the processes which led him to go to Oxford-an act equivalent to a final renunciation of the dissenters.

His admission was at the lowest point. $\mathrm{He}$ was a pauper scholaris, and was obliged to pay fees, purchasing clothes and fuel by working in various ways. He remained five years at Oxford, and finished his studies without debt; having earned money by his writings and by assisting other students not so far advanced or who were indolent, he had saved seven pounds and fifteen shillings. Notwithstanding his labors as servitor and coacher, he was so well prepared for his examinations as to be created Bachelor of Arts, and enjoyed the distinction of being the only student of Exeter College who during that year successfully passed. Though not especially religious, he did considerable benevolent work in visiting prisons.

While he was in the university Charles II. died and 
James II. succeeded him. The conflicts resulting from the king's despotic conduct, and his determination to reëstablish the Roman Catholic religion, culminated, so far as Oxford University was concerned, when he commanded the fellows of Magdalen to elect Dr. Samuel Parker, Bishop of Oxford, president of this college-a man who had been a Puritan preacher under Cromwell, a bigoted High-churchman under the Restoration, and now was ready to promote the schemes of James II. and become a papist. Parker wrote many books in a strain of contempt and fury against all dissenters, and exalted the king's authority in matters of religion to such an extent as to become blasphemous, condemning the ordinary assertion that the king was under God and under Christ as " a crude and profane expression," saying that "the king was indeed under God; he was not under Christ, but above him." 1 The fellows refused; whereupon James II. came to Oxford and summoned them into his presence. Samuel Wesley was there, and heard him cry: "You have not dealt with me like gentlemen. You have been unmannerly as well as undutiful. Is this your Church of England loyalty? . . . Go home! -get you gone! I am king! I will be obeyed! Go to your chapel this instant and admit the Bishop of Oxford!" As they would not obey they were expelled, and by a mixture of force and fraud the king succeeded in accomplishing his purpose. Parker died in a few months, as he had lived, "a drunkard and a miser, unlamented and even despised by all good men."

Though disgusted by the evidences that the king was a tyrant, and determined to give him no support, a few months afterward, when the Prince of Wales was born, Samuel Wesley wrote a poem in honor of the king and of the prince. But in one year after the scene at Magdalen

1 "Burnet's History of His Own Time," p. 443, Bohn edition. 


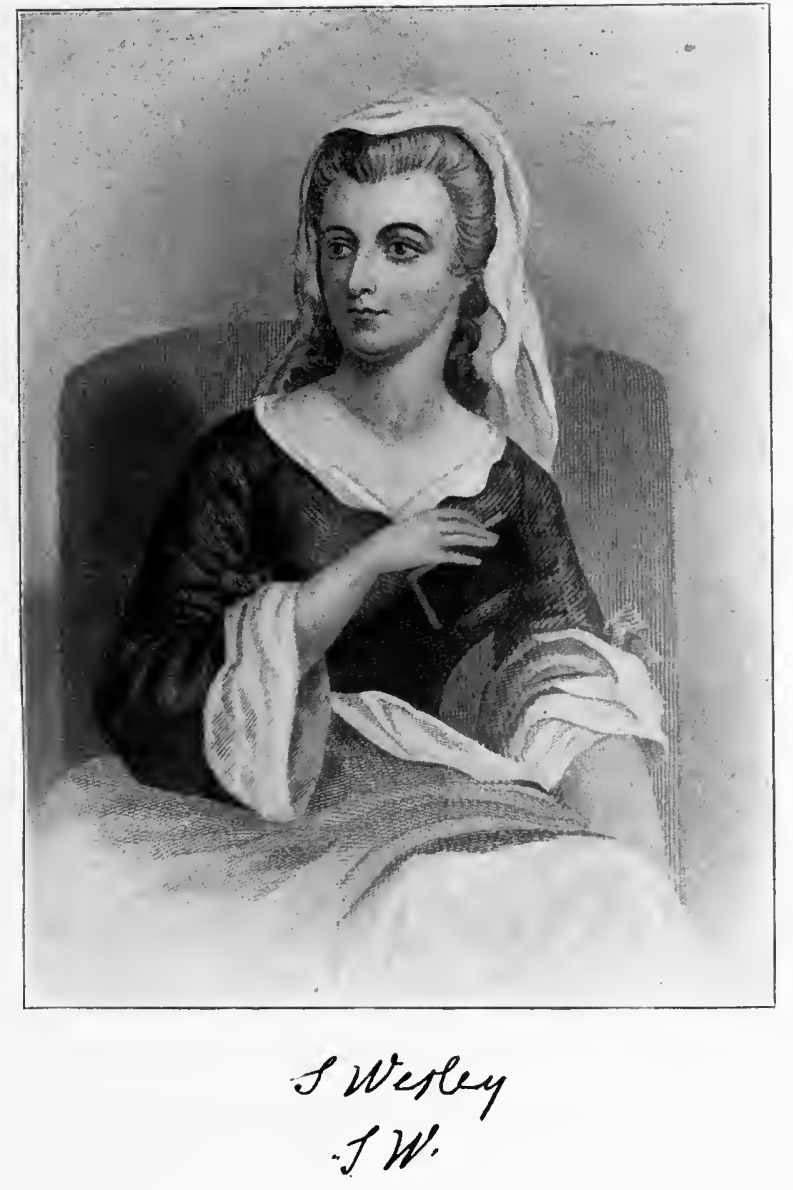


came the ignominious flight to France of James II. and the entry of William, Prince of Orange.

It was in the midst of the revolution that Samuel Wesley left the university, afterward taking M.A. both at Oxford and Cambridge. He was ordained deacon, August 7, I688, by Thomas Spratt, Bishop of Rochester; and on the $24^{\text {th }}$ of February, 1689, was ordained priest by Dr. Compton, Bishop of London. It was to him a pleasant coincidence that both these prelates were at Oxford with his father. The church in which these services were held is believed to be St. Andrew's, Holborn.

These were trying times, for twelve days before Samuel Wesley was ordained a priest Parliament declared William and Mary king and queen. In the Church of England were Stillingfleet; Tillotson, Archbishop of Canterbury; Ken, the author of "Morning and Evening Hymns"; South, in some respects the ablest intellect the church has ever had in England; Burnet; Beveridge, the oriental scholar; and Whitby, the commentator. Among the dissenters were such men as Daniel Williams, successor of Baxter, and without an equal among the Presbyterians of the time, and Matthew Henry, the expositor. Jonathan Swift, Dryden, and John Locke were writing, and Isaac Newton pursuing his discoveries.

The first gift of the church to Samuel Wesley was a curacy with an income of twenty-eight pounds per annum. For a few months he held the desirable position of naval chaplain, with a stipend, high for those times, of seventy pounds. This he resigned for another curacy at thirty pounds a year, and with his pen he earned thirty pounds additional.

Considering himself now justified in marriage, he sought as his bride Susannah, the youngest daughter and twentyfifth child of Dr. Samuel Annesley. 
Dr. Annesley was born in the year the Pilgrims sailed from Holland for the New World. Left fatherless at the age of four years, he was trained by his devout mother, and when only six years old he disclosed his intention to be a minister, and soon afterward determined to read twenty chapters of the Bible each day so long as he lived, from which habit he did not depart. He was graduated from Oxford, and from that institution received the degree of LL.D. When he was twenty-four he became a chaplain in the navy, and at twenty-eight preached the Fast-day sermon before the House of Commons. In I 652 he became minister of the Church of St. John the Apostle, in London. As his popularity increased honors were rained upon him, and in 1658 he ministered to two of the largest congregations in the city, the living of one of which yielded him seven hundred pounds.

He was, however, one of the two thousand ministers ejected by the Act of Uniformity, and endured much persecution. In I672, "when for the sake of the papists King Charles unconstitutionally suspended for a time the penal laws in matters of religion," Dr. Annesley leased a meetinghouse and gathered a large church, of which he remained pastor until his death, December 31, 1696, at the end of fifty-five years in the ministry.

In that meeting-house, in 1694 , was ordained the renowned Edmund Calamy, an event of unusual historical importance, as it was the first ordination that the dissenters had been allowed to solemnize publicly for above thirty years.

Tyerman's "Life and Times of Samuel Wesley" records a number of interesting facts in the career of Dr. Annesley, and incidents revealing his characteristics. In Williams's "Biography" it is stated that he was able to endure the coldest weather without hat, gloves, or fire; for years he 
drank nothing but water, and until his death could read without glasses the smallest print. In spirit and action he seems to have been an antetype of the true Methodist. For the last thirty years of his life he rejoiced in an uninterrupted assurance of God's forgiving love. Daniel Defoe, the author of "Robinson Crusoe," was one of his congregation, and wrote an elegy, which is, in fact, a comprehensive biography. In part it is:

His pious course with childhood he began,

And was his Maker's sooner than his own;

The heavenly book he made his only school-

In youth his study, and in age his rule.

A Moses for humility and zeal,

For innocence a true Nathanael;

Faithful as Abraham or the truer spies,

No man more honest and but few so wise.

Humility was his darling grace,

And honesty sat regent in his face.

A heavenly patience did his mind possess-

Cheerful in pain, and thankful in distress.

Dr. Annesley wedded the daughter of John White, who was a lawyer by profession, a Puritan in principles, a member of the House of Commons, chairman of the Committee for Religion, a member of the Westminster Assembly, and a radical. He delivered a speech in the House of Commons in $164 \mathrm{I}$, in which he contended "that the office of bishop and presbyter is the same; and that the offices of deacons, chancellors, vicars, surrogates, are all of human origin, and ought to be abolished, as being altogether superfluous and of no service to the church." In this speech he admits that some of the bishops were personally correct, but declares "that the bishops who are good men are all bad bishops," from which he infers "that the very office is itself a curse."

In his function as chairman of the Committee for Religion he presided at the investigation of charges against 
pastors, and in I643 published a book containing one hundred examples of scandalous clergy, the title of which is "The First Century of Scandalous, Malignant Priests." This can be consulted by visitors to the British Museum, in a volume given by George III.

Mr. White was distinguished for intellectual strength. His ecclesiastical opponents agreed with Lord Clarendon in acknowledging that " he was a grave lawyer," but considered that he was so notoriously disaffected toward the church that party feeling blinded him. His quaint epitaph in the Temple Church reads:

Here lieth a John-a burning, shining light.

His name, life, actions, were all White.

It is an interesting coincidence that the father of Samuel Wesley's mother was John White, eminent, and a member of the Westminster Assembly, and that the father of Susannah Wesley's mother was another John White, also distinguished, and a member of the Westminster Assembly.

Concerning the number of Dr. Annesley's children there is a curious anecdote, authenticated by Dr. Calamy and related by Dunton, with respect to the birth of Susannal. "How many children has Dr. Annesley?" "I believe it is two dozen, or a quarter of a hundred." George James Stevenson says: "For many years it was hard to determine which number was correct, but recent research has proved that both are; she was her father's twenty-fifth child, but she was the twenty-fourth child of her mother, Dr. Annesley's second wife.

Susannah Wesley possessed extraordinary ability and decision of character. Non-Methodist authorities, such as Southey, speak of her as " an admirable woman, of highly improved mind and a strong and masculine understanding, an obedient wife, an exemplary mother, and a fervent 
Christian." Her intellectuality and determination were displayed in the fact that, like her father and her husband, "in early youth she had chosen her path."

Much has been said justly in commendation of her, but sometimes unadvisedly, to the expressed or implied disparagement of her husband. "She examined the controversy between the dissenters and the Church of England, and satisfied herself that the dissenters were in the wrong, thus condemning her own father and grandfather." Richard Watson, in his "Life of John Wesley," remarks: "Great as were her natural and acquired talents, she must, at the age of thirteen years, have been a very imperfect judge." It is not, however, known so generally that she went much further, and reasoned herself out of evangelical Christianity into Socinianism; but from this she was reclaimed by the vigorous arguments and sound learning of her husband.

It is difficult to ascertain the extent and details of her mental training. Dr. Adam Clarke, who, through his acquaintance with John Wesley, enjoyed peculiar opportunities of ascertaining the facts, says that she appears to have had the advantage of a liberal education so far as Latin, Greek, and French enter into it. Abundant proofs exist of a thoroughly disciplined mind, extraordinary penetration, accurate knowledge on every current subject, remarkable facility in theological discussions, and excellent style as a writer. Her letters compare favorably with those of the wisest and best women in all ages, and many of them might be attributed to the wisest and best of men without discrediting their just reputation.

Her system of domestic training has elicited the admiration of all. A fact having an important bearing upon subsequent events is that Samuel Wesley's wife was throughout life a "Jacobite High-church woman, whose ecclesiastical 
creed was a matter of passionate sentiment and affection, and was cherished as warmly under Low-church William as during Queen Anne's High-church régime." 1

She believed in the divine right of kings, and in the headship of the legitimate king over the Church of England. The use of the word "Jacobite" arose from the primary manifestation of the spirit in connection with James II., who was compelled to abdicate-Jacob being the Latin form of James.

Adam Clarke says that he had from the lips of John Wesley this anecdote: "Were I," said John Wesley, " to write my own life, I should begin it before I was born, merely for the purpose of mentioning a disagreement between my father and mother. Said my father to my mother one day after family prayer, "Why did you not say "Amen" this morning to the prayer for the king?" 'Because,' said she, 'I do not believe the Prince of Orange to be the king.' 'If that be the case,' said he, 'you and I must part; for if we have two kings we must have two beds.' My mother was inflexible. My father went immediately to his study, and after a season by himself set out for London, where, being Convocation-man for the diocese of Lincoln, he remained without visiting his own house for the remainder of the year. On March 8th, in the following year (I 702) King William died, and as both my father and mother were agreed as to the legitimacy of Queen Anne's title, the cause of disagreement ceased. My father returned to Epworth, and conjugal harmony was restored."

Mr. Tyerman undertakes to show that the portion of this strange story which reflects so severely on Samuel Wesley cannot be true. They had lived together a dozen years

1 "The Churchmanship of John Wesley," by James H. Rigg, D.D. (London, Wesleyan Conference Office). 
since William and Mary's accession, and every Sunday and Friday Samuel Wesley had prayed for King William. Quoting a beautiful passage from a letter of the father to his son Samuel, he shows how deeply they loved each other: "Reverence and love your mother. Though I should be jealous of any other rival in your breast, yet I will not be of her; the more duty you pay her, and the more frequently and kindly you write to her, the more you will please your father." Tyerman assumes the absolute improbability of such a story, and, entering into details, proves that Convocation was summoned twice in the year I 70I : first, February Ioth and lasted till June 24th, when it was prorogued ; convened again December 3 Ist ; and between nine and ten weeks after, when King William died, March 8, I 702, it was again prorogued. Further, on the I 4 th and I8th of May of that same year he finds that Samuel Wesley was at Epworth attending his wife with affectionate tenderness when she became the mother of twins. $\mathrm{He}$ adduces letters written by Samuel Wesley from Epworth to Archbishop Sharpe at that time, and thus, as well as in other ways, furnishes satisfactory proof that he was not away from his family or charge for a longer period than ten or twelve weeks.

This incident, doubtless, has a foundation of truth as respects a temporary disagreement, though the extent of it is exaggerated. That its cause was a question of judgment and conscience, indicates the strength of will which characterized the parents of Wesley, and the influence of ecclesiastical and civil ideas upon their characters and actions.

An examination of Mrs. Wesley's letters, and a comparison of English and American writers, justifies Isaac Taylor's estimate: "The Wesleys' mother was the mother of Methodism in a religious and moral sense ; for her cour- 
[CHAP. ].

age, her submissiveness to authority, the high tone of her mind, its independence and its self-control, the warmth of her devotional feelings and the practical direction given to them, came up and were visibly repeated in the character and conduct of her sons.

"When Mrs. Wesley, writing to her husband concerning the irregular services she had carried on during his absence in the rectory kitchen for the benefit of her poor neighbors, said, 'Do not advise, but command me to desist,' she was bringing to its place a corner-stone of the future Methodism. In this emphatic expression of a deep compound feeling - a powerful conscientious impulse and a fixed principle of submission to rightful authority-there was condensed the very law of her son's course as the founder and legislator of a sect." 1

1 "Wesley and Methodism," by Isaac Taylor (American edition, Harper Brothers, 1860). 


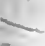




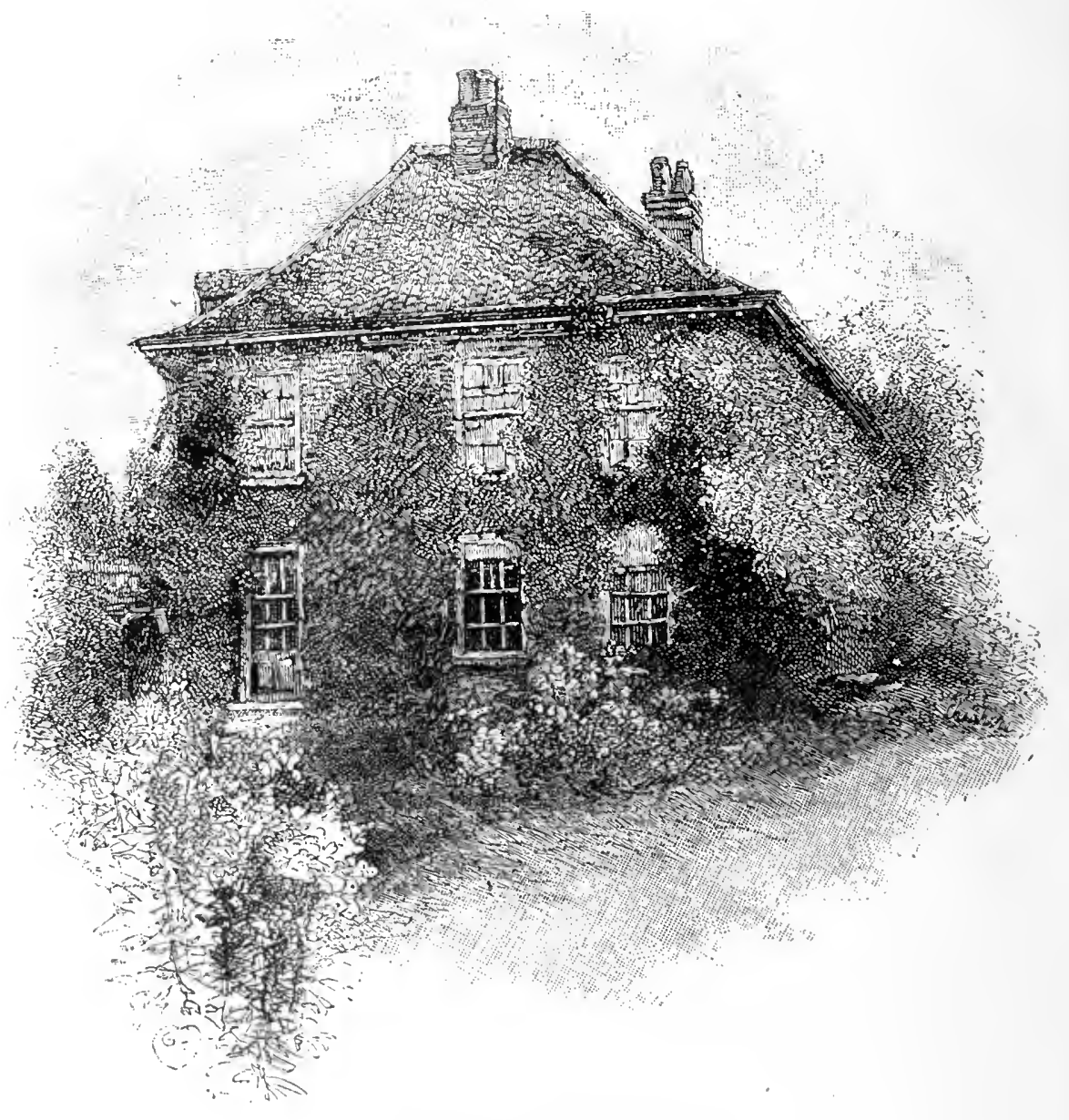

EPWORTH RECTORY. 


\section{CHAPTER III.}

THE MAN OF PROVIDENCE.

SAMUEL and Susannah Wesley were the parents of nineteen children; but when the Epworth rectory was burned in February, I 709, the parochial registers were lost, including the record of the births of their children. George James Stevenson states that after years of research eighteen out of the nineteen have been found, the years and in most cases the months of their births and the months and years of their deaths authenticated. The first was Samuel, who became an important personage; the tenth was John, who died in the year of his birth; the eleventh was Benjamin, who also died in his natal year. The fifteenth was John Benjamin, and the eighteenth, Charles. It was the love of their mother for John and Benjamin, who died so soon, that led her to name for both the next son who lived to be baptized; but for the reason assigned, no record exists concerning the place of the birth of this child. When a few hours old he was baptized "John Benjamin" by his father at Epworth; but "the second name was never used by the family, although the fact itself is preserved in documents belonging to other relatives."

In the fire which destroyed the registers of the parish of Epworth, John Wesley, then six years old, was imperiled, and his escape is one of the most extraordinary deliverances from imminent death on record. When Samuel Wesley 
settled at Epworth the inhabitants of the place generally were given to profligacy, and his denunciations of their sins led "certain lewd fellows of the baser sort" to attempt to burn the rectory. Twice they thought they had succeeded, but not till the third effort was their diabolical purpose accomplished. At midnight pieces of burning wood fell on the bed of one of the children and scorched her feet. A cry of fire from the street at that moment aroused Mr. Wesley. Discovering instantly that it was his own house, he awoke his wife, and, taking the eldest girl, burst open the nursery door and called the maid, who was sleeping there with five children. She caught the youngest, bidding the others follow. Three obeyed, but John was not awakened, and in the excitement was overlooked; but when all were thought to be safe he was heard crying in the nursery. His father ran to the stairs, but they would not bear the weight; he fell upon his knees in the hall and commended the soul of the child to God. John, awakened by the light, thought it day, and called to the maid to take him up. As no one came, he opened the curtains, and seeing flames, ran to the door, but, not being able to escape, climbed upon a chest which stood near the window, and was then seen from the yard. No ladder could be obtained, but as the house was low, one man was hoisted upon the shoulders of another, reached the window, and rescued the boy. A moment later the whole roof fell in. The father cried out to neighbors: "Let us kneel down; let us give thanks to God! He has given me all my eight children; let the house go, I am rich enough!"'

For eleven years John Wesley's chief instructor was his mother, and her system of training was afterward so highly valued by him that in 1732 he induced her, with much

1 Abridged from the graphic account in Southey's " Life of Wesley." 
difficulty, to write a full account of it. Mrs. Wesley said: "It cannot be of any service to any one to know how I, that have lived such a retired life for so many years, used to employ my time and care in bringing up my children. No one can, without renouncing the world in a most literal sense, observe my method; and there are few, if any, that would entirely devote twenty years of the prime of life in hope of saving the souls of their children; for that was my principal intention, however unskillfully managed." 1

Mrs. Wesley's chief principles were these: "At the age of one year each child was taught to fear punishment and to cry softly. Nothing for which it cried was ever to be given to a child, on the ground that to do so would be a recompense for crying, and he would certainly cry again. Children were limited to three meals a day, with nothing between meals. All were to be washed and put to bed at eight o'clock, and on no account was a servant to sit by a child until it fell asleep. As soon as they could speak, all the children were taught the Lord's Prayer, and required to repeat it every morning and every night. Six hours a day were spent at school, but with one exception none were taught to read till five years of age, and then only a single day was allowed for learning the letters of the alphabet, great and small."

The providential preservation of John led his mother to devote special pains to him. In her private meditations, under the head of "Son John," are these words: "I do

1 The Rev. J. H. Overton, present rector of Epworth, says that after seven years' residence there he can heartily indorse Mrs. Wesley's reluctance. He shows that Epworth is isolated geographically, but still more ecciesiastically, and is cut off from its own proper diocese by the rapid river Trent, often perilous to cross. On one side the parish touches Yorkshire, but is chiefly in Lancashire. There could have been few neighbors with whom the Wesleys could associate on terms of equality. They were always poor, and when John Wesley was but three years old his father was thrown into jail for debt. 
intend to be more particularly careful of the soul of this child, that Thou hast so mercifully provided for, than ever I have been, that I may do my endeavor to instill into his mind the principles of Thy true religion and virtue. Lord, give me grace to do it, sincerely and prudently, and bless my attempts with good success!"

From the beginning he would do nothing without reflecting on its fitness and propriety, but argued about everything, so that his father said: "Child, you think to carry everything by dint of argument; but you will find how little is ever done in the world by clear reason." In this particular there is a similarity between the childhood of John Wesley and that of William E. Gladstone, who was also so devout in spirit that his father admitted him to the communion-table when only eight years old. An attack of smallpox when he was between eight and nine intensified John Wesley's religious feeling, developing such patience that his mother wrote to his father that he had borne the disease like a Christian.

In the year I 7 I 4 he entered Charterhouse School, in London, where pupils were poorly fed. He suffered special privations, as the older boys had a habit of appropriating the share of animal food distributed to the younger; so that the greater part of the time bread was his only solid food. But his health was excellent, attributed by him in after years to obeying a command of his father "to run round the Charterhouse garden every morning."

According to his own testimony, here he grew less religious; he thinks that he sinned away "that washing of the Holy Ghost which he received in baptism when he was about ten years of age," and remarks concerning his Charterhouse experience that he was negligent of outward duties, and almost continually guilty of outward sins, which, to quote his own language, "I knew to be such, 
though they were not scandalous in the eye of the world. However, I still read the Scriptures and said my prayers morning and evening. And what I now hoped to be saved by was (I) not being so bad as other people, (2) having still a kindness for religion, and (3) reading the Bible, going to church, and saying my prayers."

In regard to this Tyerman utters the dictum: "John Wesley entered the Charterhouse a saint, and left it a sinner."

This remark Dr. Rigg characterizes as singularly austere." "That is to say, he entered it a saint of ten years old, and left it a sinner of seventeen. Yet the language which we have quoted from Mr. Wesley," says Dr. Rigg, "was a sentence pronounced, it must be remembered, at a time when all his judgments as to such cases were far more severe than when revised by him after many years of experience." $\mathrm{He}$ admits "that he was at this time unconverted there can be no doubt," but believesand with this an unprejudiced mind must concur-that Mr. Tyerman " uses language which can scarcely fail to convey an altogether exaggerated impression as to the character of his moral and spiritual faults and failings." The Charterhouse School at that time was a collection of youths under comparatively little restraint, full of the spirit of the age, hazing, fighting, drinking when they could; and through that school "John Wesley passed without contracting any taint of vice."

In I 7 I9 he was under the tuition of his brother Samuel, who had become head usher of Westminster School. Samuel was so much pleased with his docility and proficiency as to write to his father: "My brother Jack, I can faithfully assure you, gives you no manner of discouragement from breeding your third son a scholar. Jack is a brave boy, learning Hebrew as fast as he can."

1 "The Living Wesley," p. 55. 
When he was seventeen he entered Christ Church College, Oxford, and there remained for five years, saying his prayers publicly and privately, reading the Scriptures and other religious books, "especially comments on the New Testament;" yet, according to his own testimony, he " had not all this while so much as a notion of inward holiness; nay, went on habitually, and, for the most part, very contentedly in some or other known sin." Before the holy communion, which he was required to take three times a year, there were some intermissions and short struggles. His reputation for scholarship was high, and he indulged somewhat in poetry, selections from which, being published after his death in Dr. Whitehead's " Lives of the Wesleys," were not well received, being thought adapted to diminish the reverence in which the name of John Wesley was then held.

His mother, with much discretion, encouraged him to write verses, as this passage from a letter in 1724 shows: "I hope at your leisure you will oblige me with some more verses on any, but rather on a religious, subject." She also told him to make poetry "his diversion, and not his business." His health became impaired, and he was constantly in debt, the occasion for which embarrassment it is not easy to understand, since he received forty pounds per annum from a fund which guaranteed that sum to deserving Charterhouse pupils.

For several years his home letters contain few references to the subject of religion, and he had been four years in Oxford before he expressed a wish to become a minister of Christ.

On consulting his parents, a difference of opinion appeared, and a letter exists, written by his mother, which contains almost the only passage that shows indiscretion in that remarkable woman: "I was much pleased with it 
(your letter to your father about taking orders), and liked the proposal well; but it is an unhappiness almost peculiar to our family that your father and I seldom think alike. I approve the disposition of your mind, and I think the sooner you are a deacon the better; because it may be an inducement to greater application in the study of practical divinity. . . . Mr. Wesley differs from me, and would engage you, I believe, in critical learning, which, though incidentally of use, is in no wise preferable to the other." Later his father pressed him to enter into holy orders, and he became a divinity student.

At Oxford he wrote frequently and in the most filial spirit to his parents, and sustained an animated correspondence with his sisters.

One of the first books that John Wesley studied was that attributed to Thomas à Kempis-" The Imitation of Christ," of which he wrote to his mother, who responded dubiously. He was also much impressed by Jeremy Taylor's "Holy Living and Dying." His father placed a higher estimate upon À Kempis than did his mother, and expressed the opinion that, "making some grains of allowance, he may be read to great advantage; notwithstanding all his superstition and enthusiasm, it is almost impossible to peruse him seriously without admiring, and in some measure imitating, his heroic strains of humility, piety, and devotion." Jeremy Taylor perplexed John Wesley as to the evidence of sins forgiven, and in the course of correspondence with his mother he repudiated the views of Taylor, and settled himself that predestination logically requires the conclusion that God is the author of sin and injustice, expressing the belief that "it is a contradiction to the clearest ideas that we have of the divine nature and perfections." Speaking, many years later, of his spiritual growth, he said: "When I met with it ["The Imitation of Christ "], 
the nature and extent of inward religion, the religion of the heart, appeared to me in a stronger light than ever it had done before." Taylor's " Holy Living and Dying," he declares, led him to resolve to dedicate his life to God, " being thoroughly convinced there was no medium;" and he testifies that he sought these things from that hour. In the order of the development of John Wesley's thought concerning the true Christian life, Jeremy Taylor so changed his views that "The Imitation of Christ," which at first disaffected him, afterward seemed in most respects adapted for a rule of life.

While pursuing these studies $\mathrm{Mr}$. Wesley met a religious friend-it is not known to whom he refers-and his influence united with that of these two great works, in causing him " to begin to alter the whole form of my [his] conversation, and to set in earnest upon a new life."

The high respect that Samuel Wesley and his wife felt for each other's intellectual powers cannot be better shown than by two sentences, on the subject of settling the true doctrine of predestination. Mrs. Wesley wrote to her son: "I will tell you my thoughts of the matter; if they satisfy not, you may desire your father's direction, who is surely better qualified for a casuist than I." Whereas, in discussing the principles set forth by Thomas à Kempis, his father wrote to him to consult his mother, for "she has leisure to boult the matter to the bran."

After suitable preparation he was ordained deacon in the autumn of 1725 by Dr. Potter, then Bishop of Oxford, who is described as a man of talent and learning, and a High-churchman who spoke kindly of the first Methodists. Wesley referred to him in a sermon written in 1787 , thanking Almighty God for the counsel which the bishop had given him, to the effect that if he wished to be extensively useful he must not spend his time in contend- 


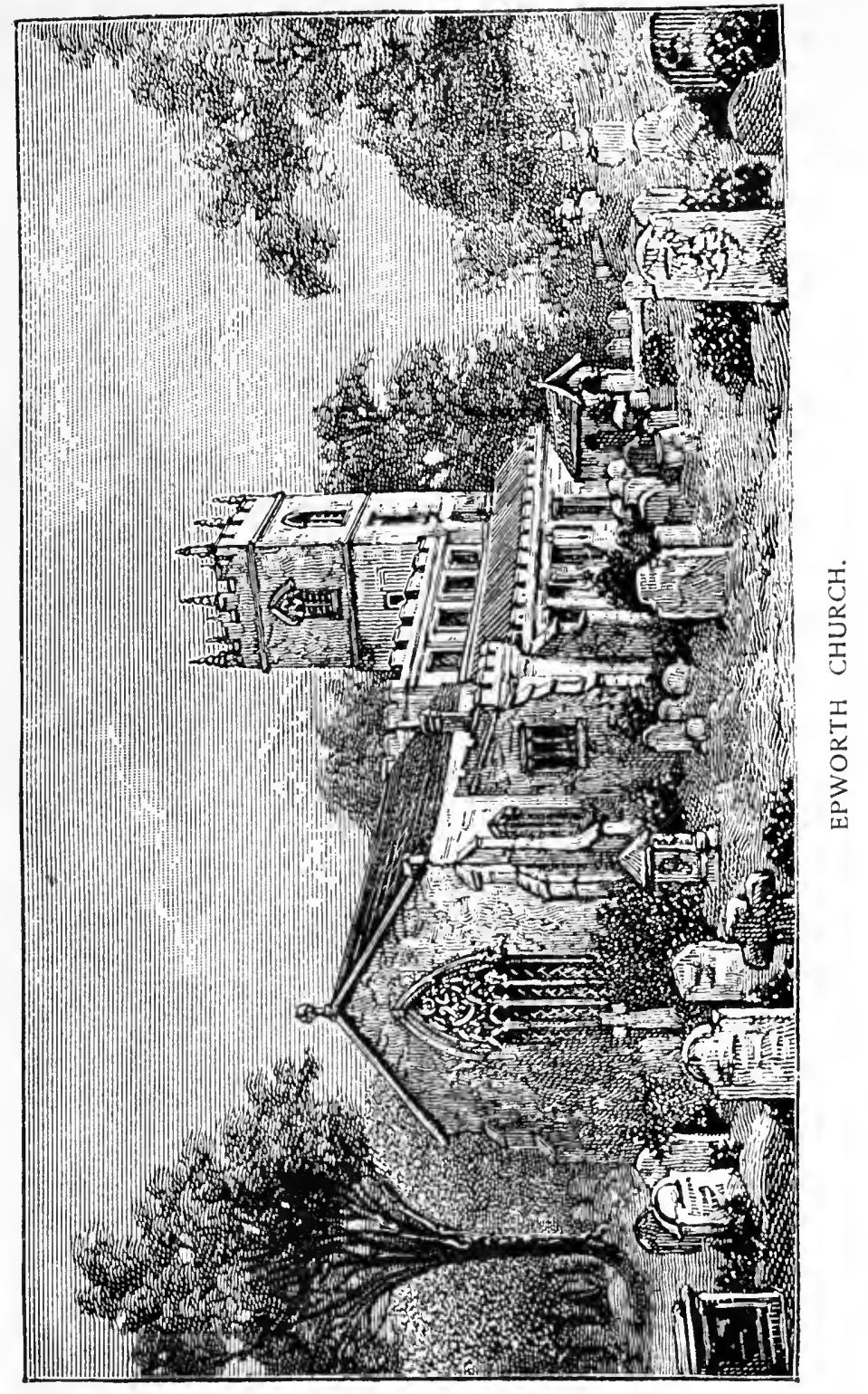




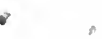


ing for or against things of a disputable nature, but in testifying against notorious vice, and in promoting essential holiness. $\mathrm{He}$ offered himself for a fellowship at Lincoln College, and although he had not become conspicuously strict in his manner of life, yet his religious principles were the subject of satire, and opponents endeavored to make him ridiculous; but owing to his unquestioned scholarship and universally recognized abilities, his brother Samuel's powerful influence, and the friendship of the rector, he was elected fellow in March, I726, to the delight of his family.

He returned to Oxford and began his work on the 2 Ist of September. He had not yet taken his master's degree, but such were his gifts and attainments that within two months he was elected Greek lecturer and moderator of the classes.

His methods of study after he entered upon his fellowship, as stated by himself, were: Mondays and Tuesdays devoted to Greek and Roman classics, historians, and poets; Wednesdays to logic and ethics; Thursdays to Hebrew and Arabic; Fridays to metaphysics and natural philosophy; Saturdays to oratory and poetry, chiefly composing; Sundays to divinity. Besides these, he studied French, and entertained himself with experiments in natural science.

He made a study of William Law's "Christian Perfection" and "Serious Call," books which taught the necessity of a change of nature, a renunciation of the world and worldly tempers, self-denial, and mortification.

This author was a scholar of renown, a fellow of Emanuel College, Cambridge, and officiated for a time as curate in London, but refused to take the oaths prescribed by the Parliament for the clergy of the Church of England on accession of George I. Obliged on this account to leave 
the pulpit, he took a position as tutor of Edward Gibbon, father of the historian. Law was a man of such ability as to affect profoundly the master mind of Samuel Johnson, and produced such an impression upon Macaulay that he expresses surprise that Johnson should have pronounced William Law no reasoner; and, referring to his controversy with Bishop Hoadley, he says that Law " in mere dialectical skill had few superiors. That he was more than once victorious over Hoadley no candid Whig will deny." Gibbon also commends him in the very highest terms, speaking of his "Serious Call" as a masterpiece. "Many of his portraits are not unworthy of the pen of La Bruyère. . . . A philosopher must allow that he exposes with equal severity and truth the strange contradiction between the faith and practice of the Christian world."

Wesley took his degree of Master of Arts February I4, I727, delivering three orations in Latin-" De Anima Brutorum," "De Julio Cæsare," and "De Amor Dei," which have not been preserved.

He formed a thoroughly ascetic scheme of life, writing to his mother that he had taken leave of leisure and intended to be busy the rest of his life, if God should give him health. Six times a week disputations were held at Lincoln College, and over these John Wesley presided. Though he had been a deeply interested student of logic, he attributes to the discharge of this function much of the power that was so useful in subsequent years. "I have since," said he, "found abundant reason to thank God for giving me this honest art, for by this, when men have held me in by what they call demonstration, I have been able many times to dash them in pieces; and in spite of all its covers, to touch the very point where the fallacy lay, and it flew open in a moment."

From August, I 727 , to November, I729, he officiated 
as his father's curate at Epworth and Wroote. While holding this position he was absent about three months, and on the $22 \mathrm{~d}$ of September, 1728 , was ordained priest at Oxford by Bishop Potter, who had ordained him deacon.

Wesley would undoubtedly have remained many years at Epworth if the rector of Lincoln College, who had rendered so many services to the Wesley family that Samuel Wesley used to say, "I can refuse him nothing," had not written a letter stating that to preserve discipline and good government "it was [at a meeting of the society of Lincoln College], in the opinion of all present, judged necessary that the junior fellows, who should be chosen moderators, shall in person attend the duties of their office, if they do not prevail with some of the fellows to officiate for them." In consequence of this appeal John Wesley returned to Oxford, November 22, I 729, and there remained for six years.

The movement at Oxford to which the term "Methodist" was finally applied began during John Wesley's absence at Epworth, and Charles appears to have been its originator. $\mathrm{He}$ attended the weekly sacrament, and induced two other students, Robert Kirkham and William Morgan, to associate with him. Later George Whitefield, James Hervey, and twelve others, whose names are given by most of Wesley's biographers, besides a few who cannot now be ascertained, affiliated with them. The extreme strictness of their conduct excited ridicule; their frankness in rebuking sin developed personal hostility; they were spoken of contemptuously as the "Holy Club," "Bible Bigots," "Bible Moths," the "Godly Club," "Supererogation Men," "Sacramentalists," "Methodists," and, as Mr. Wesley observes in his journal, were "sometimes dignified with the name of 'Enthusiasts' or the 'Reform Club." " These in I 735 were known as Oxford Methodists. The name "Methodist" appears to have occurred 
sporadically in secular history and in earlier Christianity. A sermon preached in I639 is extant, which refers to certain contemporary "Methodists."

The state of morals in Oxford and elsewhere was lower than it had ever been. The Bishop of Lichfield had said in I 724: "The Lord's day is now the devil's market-day. More lewdness, more drunkenness, more quarrels and murders, more sin, is contrived and committed on this day than on all the other days of the week together. . . . Sin, in general, is grown so hardened and rampant as that immoralities are defended, yea, justified on principle. . . Every kind of sin has found a writer to teach and vindicate it, and a bookseller and hawker to divulge and spread it." 1

An exceedingly able work ${ }^{2}$ traces the religious and moral life of England from a very early period, showing the rise, principles, and growth of the nonconformist and dissenting sects until just before the rise of Wesleyan Methodism, which, in the opinion of the author, was the darkest period. The Presbyterian congregations suddenly lapsed into Arianism, and the Presbyterian churchesfounded at the period of the ejection of the two thousand ministers, in I662, did not exist for more than fifty years. Even where the Presbyterian congregations maintained their orthodoxy their religious life was lamentable. The Baptists and Independents, though not falling into Arianism, lacked leaders, and accomplished but little in checking the general evil tendencies. The author sums up his conclusion in this sentence: "The darkest period in the religious annals of England was that prior to the preaching of Whitefield and the two Wesleys."

1 Tyerman, vol. i., p. 62 .

2 "The Inner Life of the Religious Societies of the Commonwealth," by R. Barclay (London). 
It has recently been suggested that the testimonies to the general immorality of that age were of the nature of a fanatical denunciation. This has led two authors of the English church candidly to reconsider the subject; and lest an extravagant conclusion should be adduced from the representation herein made, the result of their investigation is stated: " Throughout the whole of the eighteenth century almost all writers who had occasion to speak of the general condition of society joined in one wail of lament over the irreligion and immorality that they saw all around them. This complaint was far too universal to mean little more than a general and somewhat conventional tirade upon the widespread corruption of human nature." The authors then observe that "even if the severe judgment passed by contemporary writers upon the spiritual and moral condition of their age may be fairly qualified by some such consideration, it must certainly be allowed that religion and morality were, generally speaking, at a lower ebb than they have been at many other periods."

The life of John Wesley was a continual protest against the moral evils and the religious laxity of the time. $\mathrm{He}$ observed the Wednesday and Friday fasts, tasting no food till three in the afternoon. He walked twenty-five miles a day in hot weather as well as in cold, and frequently, with his brother, would read as they walked for a distance of ten or twelve miles.

$\mathrm{He}$ and his colleagues carried asceticism and devotion to study so far as nearly to ruin their health. He set apart an hour or two every day for prayer, partook of the holy communion weekly, soon became much more devoted, and prayed with intense feeling, visited prisons, gave away all the money he could obtain, cut off not only

1 "The English Church in the Eighteenth Century," vol. i., by C. J. Abbey and J. H. Overton. 
[CHAP. 111 .

superfluities, but many things deemed by others necessities, until by failing health, and especially by severe and frequent hemorrhages, he was brought to the gates of death.

Naturally they were much opposed. Morgan died prematurely, and Wesley was charged with being the cause of it by recommending excessive fasting. He succeeded, however, in making so plain a statement as to convince the father of Mr. Morgan that he was not blameworthy. Nevertheless Wesley's system at that time was such as, carried fully and logically to its end, would in many instances lead to such a result.

Mr. Morgan, in his weakness, had been afflicted by wandering of the mind, and Samuel Wesley thus refers to him :

Does M- weakly think his time misspent?
Of his best actions can he now repent?
Others, their sins with reason just deplore,
The guilt remaining when the pleasure's o'er;
Since the foundations of the world were laid,
Shall he for virtue first himself upbraid?
Shall he, what most men to their sins deny,
Show pain for alms, remorse for piety?
Can he the sacred Eucharist decline?
What Clement poisons, here the bread and wine?
Or does his sad disease possess him whole,
And taint alike his body and his soul?
If to renounce his graces he decree,
Oh, that he would transfer the stock to me!
Alas! enough what mortal e'er can do
For Him who made him and redeemed him too?
Zeal may to man beyond desert be showed;
No supererogation stands to God.

The condition to which they were reduced is described in graphic manner by John Wesley's physician, John Whitehead, M.D., ${ }^{1}$ and immortalized by a poem written privately

1 "Lives of the Wesleys" (London, 1793; reprinted in Boston, 1844). 
to his brother Charles by Samuel Wesley, after a visit to Oxford, under date of April 20, I 732:

One or two questions more before I end;

They much concern a brother and a friend.

Does John seem bent beyond his strength to go,

To his frail carcase literally a foe?

Lavish of health as if in haste to die,

And shorten time t' ensure eternity?

John Wesley's father died on the $25^{\text {th }}$ of April, 1735 . He was possessed of great vivacity and wit, of a powerful memory, stored with all gospel learning. $\mathrm{He}$ has been represented as of a harsh and stern character; but, says Tyerman, "nothing can be further from the truth than this;" and in proof of the statement quotes Miss Wesley, his granddaughter, as saying: "His children idolized his memory." Commenting upon this, his most elaborate biographer remarks: "They would scarce have done that if he had been ungentle and gruff. It is true he kept his children in the strictest order; but he also evinced the greatest tenderness, and thus secured both the respect and love of his numerous family. To his judicious method of instructing and managing his offspring the Methodists owe an incalculable debt of gratitude."

His personality was impressed upon all his children; in particular upon Samuel and John. As a Christian he was earnest, devout, conscientious. As a parish minister his rule was the utmost fidelity and the utmost self-sacrifice. The testimonies of John Wesley, recorded in his journal, delivered in his sermons, and written in a letter to his father, constitute a tribute of which few men are worthy. A few months before his death he wrote: "For many years you have diligently fed the flock committed to your care with the sincere milk of the Word. Many of them 
the Great Shepherd has, by your hand, delivered from the hand of the destroyer, some of whom have already entered into peace, and some remain unto this day. For myself, I doubt not but when your warfare is accomplished you will go to your grave, not with sorrow, but as a ripe shock of grain, full of years and of victories."

He recorded in his journal several years later these words concerning a visit to Epworth: "But let no one think his labor of life is lost because the fruit does not immediately appear. Near forty years did my father labor here, and he saw little fruit of all his labot. I took some pains among this people too, and my strength also seemed spent in vain; but now the fruit appeared."

Dr. John Burton, of Oxford, shortly after this event took great interest in the colonization of Georgia, and urged John Wesley to become a missionary. The origin of that commonwealth was equally romantic and philanthropic. The original proposition was to plant a new colony south of Carolina to be tilled by British and Irish laborers, "without the dangerous help of blackamoors." In those days men were hanged for thefts, and in Great Britain on the average four thousand men were annually imprisoned for debt. It was possible for a small debt that a man should be condemned to prison for life. This attracted the attention of James Oglethorpe, a member of the British Parliament, educated, vigorous, a brilliant soldier, who in 1728 planned an asylum in America where men would not be reproached or embarrassed on account of previous poverty, and slavery would be unknown.

On the 9th of June, I 732, George II. granted a charter to Oglethorpe and his associates. Parliament promoted the scheme by appropriating ten thousand pounds. Many benevolent persons contributed, and the Society for Propagating the Gospel in Foreign Parts took a deep interest in 


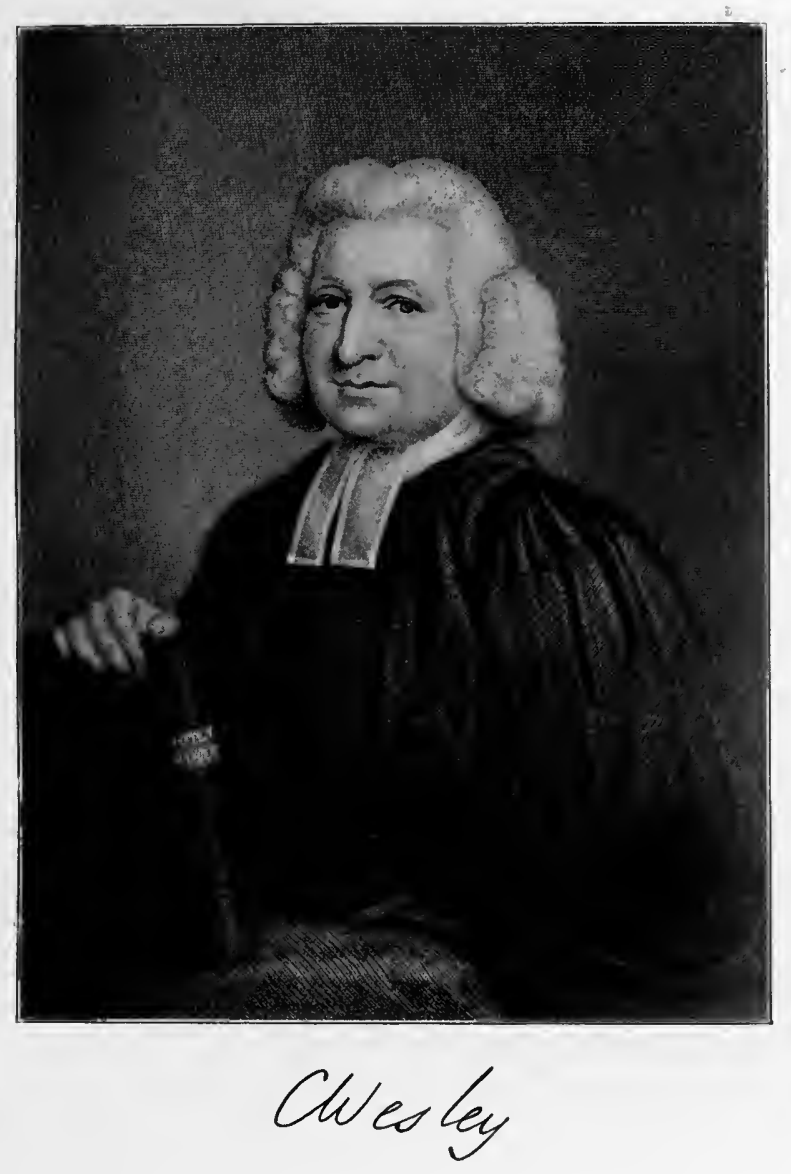



it. In November, I 732, Oglethorpe embarked with one hundred and twenty emigrants.

Thus Georgia was settled. Jews were admitted, but Roman Catholics excluded; "the purpose was a place of refuge for the distressed people of Britain and the persecuted Protestants of Europe." On the last day of October, I 733, the persecuted Moravians, being invited by the Society in England for Propagating the Gospel, emigrated to Georgia. Oglethorpe met them at Charleston, and five days later they encamped near Savannah.

Oglethorpe sailed in April, I 734, for England, and during his absence many disturbances arose. Throughout England Georgia was praised in a famous sermon in these words: "Slavery, the misfortune, if not the dishonor, of other plantations, is absolutely proscribed. . . . The name of slavery is here unheard, and every inhabitant is free from unchosen masters and oppression."

The population of Georgia prior to the arrival of John Wesley and his companions had been made up by four companies: the first of Englishmen, the second of Lutherans from Saltzburg in Germany, the third of Scotch Highlanders, and the fourth of Moravians. February 6th a new company, of three hundred emigrants, conducted by Oglethorpe, landed in Georgia ; among them certain Moravians, and John and Charles Wesley. John hoped to become not only a missionary to the English, but an apostle to the Indians. Charles was secretary to Oglethorpe. ${ }^{1}$

On the voyage the strictness of Wesley and those who sympathized with him was probably never surpassed. From four to five in the morning they prayed privately; from five till seven they read the Bible together; at seven they breakfasted; at eight had public prayers and expounded the lesson for the day; from nine to twelve John

1 Bancroft's " History of the United States," vol. iii. 
Wesley studied German and Charles wrote sermons; at noon they met for prayer, and at one dined; from dinner until four they read or gave special instruction to those willing to receive it; at four they had evening prayer and expounded the lesson; from five to six they spent in private prayer, and from six to seven each read in his own cabin to three detachments of the English passengers; at seven Wesley joined with the Moravians in their service; at eight they met in private to exhort each other, and between nine and ten retired.

A storm arose, during which the Moravians were so calm and so ready to die that Wesley concluded that he had not the faith which they possessed. The voyage consuming nearly four months, they were unable to effect a landing until February 5, I 736. Upon his arrival in Georgia he encountered a Moravian elder, Spangenberg, who cross-examined him with regard to his religious experience, with the effect of increasing Wesley's doubt of its genuineness.

Wesley was greatly disappointed in not finding a suitable opportunity to preach to the Indians; nor were the colonists generally willing to hear him. Not understanding human nature, he was easily imposed upon, and was betrayed and insulted by those whom he endeavored to benefit. He was unduly severe, unnecessarily provoking resistance; and the people would not endure his High-church views, for he made a matter of conscience of many things not prescribed in the Bible, withal revealing his inmost thoughts to every one; and thus those who became incensed had abundant material to kindle and feed the flame of prejudice against him. Daily he held early and also forenoon services, inculcated fasting of the severest kind, required something scarcely to be distinguished from confession as a preparation for communion, celebrated 
the Lord's Supper weekly, refused it to all who had not been baptized, insisted on baptism even of infants by immersion, rebaptized the children of dissenters, and absolutely refused to bury those who had not received episcopal baptism. ${ }^{1}$

Great excitement was produced by his refusing the holy communion to Belzius, one of the most godly men in the colony, the Lutheran pastor of the Saltzburgers. This is the entry on that subject in his unpublished journal: "Sunday, July I 7, I 737. I had occasion to make a very unusual trial of the temper of Mr. Belzius, pastor of the Saltzburgers, in which he behaved with such loveliness and meekness as became a disciple of Jesus Christ." In his journal for September 30, I749, he published a letter from this man, received in the preceding July, and after it writes these words: "What a truly Christian beauty and simplicity breathe in these lines! And yet this very man, when I was at Savannah, did I refuse to admit to the Lord's table because he was not baptized; that is, not baptized by a minister who had been episcopally ordained. Can any one carry High-church zeal higher than this? And how well have I since been beaten with mine own staff!"

Notwithstanding his austerity, he paid attentions, looking toward matrimony, to a young woman not at all suited to him. Whether the engagement was actually formed, and, if so, which broke it, are disputed questions. But subsequent to these attentions, and after she had become Mrs. William Williamson, she did not, in his opinion, always act consistently with a Christian profession, habitually neglecting some of the instructions which Wesley gave to the church. In accordance with his uniform course, after private reproof by letter, on the first Sunday in July, I 737, he rebuked her, and on the first Sunday in August 
[CHAP. III.

repelled her from the holy communion. The next day the recorder of Savannah issued the following warrant:

\section{Georgia, Savannah. [ss.]}

"To all constables, tithing-men, and others, whom these may concern:

"You, and each of you, are hereby required to take the body of John Wesley, clerk;

"And bring him before one of the bailiffs of the said town, to answer the complaint of William Williamson and Sophia his wife, for defaming the said Sophia, and refusing to administer to her the sacrament of the Lord's Supper, in a public congregation, without cause; by which the said William Williamson is damaged one thousand pounds sterling: and for so doing, this is your warrant, certifying what you are to do in the premises. Given under my hand and seal the 8th day of August, Anno Dom. I 737.

"Tho. Christie."

A grand jury of forty-four members sat upon the case. Of these Mr. Wesley says: "One was a Frenchman who did not understand English, one a Papist, one a professed infidel, three Baptists, sixteen or seventeen others, Dissenters, and several who had personal quarrels against me and had openly vowed revenge." A majority found the following bill :

"That John Wesley, clerk, had broken the laws of the realm, contrary to the peace of our sovereign lord the king, his crown and dignity:

"I. By speaking and writing to Mrs. Williamson, against her husband's consent.

" 2 . By repelling her from the holy communion.

" 3. By not declaring his adherence to the Church of England. 
"4. By dividing the Morning service on Sundays.

" 5. By refusing to baptize Mr. Parker's child, otherwise than by dipping, except the parents would certify it was weak and not able to bear it.

"6. By repelling William Gough from the holy communion.

"7. By refusing to read the Burial service over the body of Nathaniel Polhill.

" 8. By calling himself Ordinary of Savannah.

"9. By refusing to receive William Aglionby as a godfather only because he was not a communicant.

" Io. By refusing Jacob Matthews for the same reason; and baptizing an Indian trader's child with only two sponsors."

Commenting on the tenth specification, Mr. Wesley wrote in his journal: "This, I own, was wrong; for I ought, at all hazards, to have refused baptizing it till he had procured a third."

Twelve of the grand jurors, of whom three were constables and six tithing-men, refused to sign the presentment, giving the following reasons:

"WherEas two presentments have been made, the one of August 23d, the other of August 3Ist, by the grand jury for the town and county of Savannah, in Georgia, against John Wesley, clerk;

"We, whose names are underwritten, being members of the said grand jury, do humbly beg leave to signify our dislike of the said presentments; being, by many and divers circumstances, thoroughly persuaded in ourselves that the whole charge against Mr. Wesley is an artifice of Mr. Causton's, designed rather to blacken the character of $\mathrm{Mr}$. Wesley than to free the colony from religious tyranny, as he was pleased, in his charge to us, to term it. But as these circumstances will be too tedious to trouble your 
honors with, we shall only beg leave to give the reasons of our dissent from the particular bills.

"With regard to the first bill, we do not apprehend that Mr. Wesley acted against any law by writing or speaking to Mrs. Williamson, since it does not appear to us that the said Mr. Wesley has either spoke in private or wrote to the said Mrs. Williamson since March I2th (the day of her marriage), except one letter of July 5 th, which he wrote at the request of her uncle, as a pastor, to exhort and reprove her.

"The second we do not apprehend to be a true bill; because we humbly conceive Mr. Wesley did not assume to himself any authority contrary to law; for we understand, 'Every person intending to communicate, should signify his name to the curate at least some time the day before;' which Mrs. Williamson did not do, although $\mathrm{Mr}$. Wesley had often, in full congregation, declared he did insist on a compliance with that rubric, and had before repelled divers persons for non-compliance therewith.

"The third we do not think a true bill; because several of us have been his hearers when he has declared his adherence to the Church of England in a stronger manner than by a formal declaration: by explaining and defending the Apostles', the Nicene, and the Athanasian creeds, the Thirty-nine Articles, the whole Book of Common Prayer, and the Homilies of the said church ; and because we think a formal declaration is not required but from those who have received institution and induction.

"The fact alleged in the fourth bill we cannot apprehend to be contrary to any law in being.

"The fifth we do not think a true bill; because we conceive Mr. Wesley is justified by the rubric, viz., 'If they (the parents) certify that the child is weak, it shall suffice 
to pour water upon it;' intimating (as we humbly suppose) it shall not suffice if they do not certify.

"The sixth cannot be a true bill; because the said William Gough, being one of our members, was surprised to hear himself named without his knowledge or privity, and did publicly declare it was no grievance to him, because the said John Wesley had given him reasons with which he was satisfied.

"The seventh we do not apprehend to be a true bill; for Nathaniel Polhill was an Anabaptist, and desired in his lifetime that he might not be interred with the office of the Church of England. And further, we have good reason to believe that Mr. Wesley was at Frederica, or on his return thence, when Polhill was buried.

"As to the eighth bill we are in doubt, as not well knowing the meaning of the word 'Ordinary.' But for the ninth and tenth we think Mr. Wesley is sufficiently justified by the canons of the church, which forbid 'any person to be admitted godfather or godmother to any child before the said person has received the holy communion'; whereas William Aglionby and Jacob Matthews had never certified Mr. Wesley that they had received it."

There was a fatal legal defect in the composition of the grand jury, yet as Mr. Causton, Mrs. Williamson's uncle, was the chief magistrate, it was impossible for Mr. Wesley to secure a trial. He appeared at six or seven courts successively, but in vain; until, convinced that he could not obtain justice, he determined to go back to England, if he could find opportunity to do so, and lay the matter before General Oglethorpe.

The account in his journal of his adventures is as thrilling as narratives of the most celebrated explorers, but not more so than the delineation of his spiritual experiences.

He hoped, however, to return, as his journal for January 
22, I 738, contains this entry: "I took my leave of America (though, if it please God, not forever)." So lofty was Wesley's ideal that he considered his mission to Georgia a failure; but when George Whitefield arrived there some months after Wesley returned to England, he found reason to write in his journal: "The good that Mr. John Wesley has done in America is inexpressible. His name is very precious among the people; and he has laid a foundation that I hope neither men nor devils will ever be able to shake. Oh that I may follow him as he has followed Christ!"

On the voyage Mr. Wesley wrote: "I went to America to convert the Indians; but oh, who shall convert me? . . . It is now two years and almost four months since I left my native country in order to teach the Georgian Indians the nature of Christianity; but what have I learned myself in the meantime? Why (what I the least of all suspected), that I who went to America to convert others was never myself converted to God." This is part of a general description of Wesley's spiritual condition as he then estimated it; but many years later he inserted after the words just quoted: "I am not sure of this." At another point where he had expressed doubts as to whether he was a Christian he adds a foot-note: "I had even then the faith of a servant, though not of a son." And after declaring himself "a child of wrath" he writes this: "I believe not." 1

1 Wesley's "Works," vol. iii., p. 56, American edition. 


\section{CHAPTER IV.}

GENESIS AND GROWTH OF METHODISM.

LANDING at Deal, England, February I, 1738, John Wesley hastened to London. That he had made the acquaintance of the Moravians, and acquired the German, Spanish, and Italian tongues so that he could read and speak them, seemed to him a sufficient compensation for all his hardships. On the 4 th he preached in the Church of St. John the Evangelist from the text, "If any man be in Christ, he is a new creature," and records: "I was afterward informed that many of the best in the parish were so offended that I was not to preach there any more."

On the 7th of February he met Peter Bohler, and ever after regarded the meeting as a turning-point in his spiritual development. This devout Moravian taught him what faith is and what are its fruits. For some days his conversations with Bohler were frequent; and on the 22d of April the subject of instantaneous conversion was considered, and by the arguments of Bohler, the teachings of the Scriptures, and the testimony of certain witnesses, the eyes of John Wesley were opened to see that such conversion is possible.

Peter Bohler, nine years younger than John Wesley, was a native of Frankfort, Germany, and was educated at the University of Jena, where he afterward studied theology. He became a Moravian at sixteen, and was ordained by Zinzendorf at twenty-five. He was on his way to Carolina when he met Wesley in London. At that time he knew 
no English, and Charles Wesley gave him his first lessons. In the Moravian meetings he spoke in Latin, a learned tailor interpreting his addresses.

Bohler, after these conversations, in a letter to Zinzendorf, analyzed John Wesley, stating that he was "a goodnatured man, knew he did not properly believe on the Saviour, and was willing to be taught." $\mathrm{He}$ affirmed that of faith in Jesus "Wesley had no other idea than the generality of people had. They justify themselves, and therefore they always take it for granted that they believe already, and try to prove their faith by their works, and thus so plague and torment themselves that they are at heart very miserable." The "Methodist Magazine" for I 854 contains much of interest on this subject.

Confident of his sincerity, Bohler advised him to " preach faith until he experienced it." On the $7^{\text {th }}$ of May he spoke in two different churches, and in each was informed that he could not be allowed to occupy the pulpit again. On the 9th he was heard with the same result, and this followed wherever he appeared.

During the greater part of this time he was continually sad because he felt under condemnation.

His journal contains an epitome of his religious life, culminating in a spiritual change destined to become the soul of Methodism :

"When I met Peter Bohler again, he consented to put the dispute upon the issue which I desired, namely, Scripture and experience. I first consulted the Scripture. But when I set aside the glosses of men, and simply considered. the words of God, comparing them together, endeavoring to illustrate the obscure by the plainer passages, I found they all made against me, and was forced to retreat to my last hold, ' that experience would never agree with the literal interpretation of those Scriptures. Nor could I, there- 
fore, allow it to be true, till I found some living witnesses of it.' He replied, he could show me such at any time; if I desired it, the next day. And, accordingly, the next day he came again with three others, all of whom testified, of their own personal experience, that a true living faith in Christ is inseparable from a sense of pardon for all past, and freedom from all present, sins. They added with one mouth that this faith was the gift, the free gift, of God, and that he would surely bestow it upon every soul who earnestly and perseveringly sought it. I was now thoroughly convinced; and by the grace of God I resolved to seek it unto the end: (I) By absolutely renouncing all dependence, in whole or in part, upon my own works or righteousness; on which I had really grounded my hope of salvation, though I knew it not, from my youth up. (2) By adding to the constant use of all the other means of grace continual prayer for this very thing-justifying, saving faith; a full reliance on the blood of Christ shed for me; a trust in him as my Christ, as my sole justification, sanctification, and redemption.

"I continued thus to seek it (though with strange indifference, dullness, and coldness, and unusually frequent relapses into $\sin$ ) till Wednesday, May 24th. I think it was about five this morning that I opened my Testament on those words: "There are given unto us exceeding great and precious promises; even that ye should be partakers of the divine nature' (2 Pet. i. 4). Just as I went out I opened it again on those words: 'Thou art not far from the kingdom of God.' In the afternoon I was asked to go to St. Paul's. The anthem was: 'Out of the deep have I called unto thee, $O$ Lord. Lord, hear my voice: O let thine ears consider well the voice of my complaint. If thou, Lord, wilt be extreme to mark what is done amiss, O Lord, who may abide it? For there is mercy with thee; there- 
fore shalt thou be feared. O Israel, trust in the Lord: for with the Lord there is mercy, and with him is plenteous redemption. And he shall redeem Israel from all his sins.'

"In the evening I went very unwillingly to a society in Aldersgate Street, where one was reading Luther's preface to the Epistle to the Romans. About a quarter before nine, while he was describing the change which God works in the heart through faith in Christ, I felt my heart strangely warmed. I felt I did trust in Christ, Christ alone, for salvation; and an assurance was given me that he had taken away my sins, even mine, and saved me from the law of sin and death.

"I began to pray with all my might for those who had in more especial manner despitefully used me and persecuted me. I then testified openly to all there what I now first felt in my heart. But it was not long before the enemy suggested, 'This cannot be faith, for where is thy joy?' Then was I taught that peace and victory over sin are essential to faith in the Captain of our salvation; but that, as to the transports of joy that usually attend the beginning of it, especially in those who have mourned deeply, God sometimes giveth, sometimes withholdeth them, according to the counsels of his own will."

On the I $3^{\text {th }}$ of June, Wesley, with several companions, began a journey to Herrnhut, the chief settlement of the Moravians, by way of Rotterdam and Amsterdam to Cologne, whence they embarked on the Rhine, traveling in a boat drawn by horses four days and nights to Mayence. At Frankfort, not being provided with passports, they were not allowed to enter the city ; but, aware that Peter Bohler's father lived there, they sought his interposition and were admitted. Thence they proceeded to the old castle at Ronneburg, the abode of Count Zinzendorf, where they remained two weeks. 
While treated with kindness, Wesley was not allowed to partake of the Lord's Supper. The reasons given were these: "First, the congregation saw him to be homo perturbatus, and that his head had gained an ascendency over his heart. Second, they thought that communing with them might interfere with the plan which he had formed of doing good as a clergyman of the English church, which plan they approved." 1

On the Ist of August Wesley arrived at Herrnhut, about thirty English miles from Dresden, in Upper Lusatia, on the border of Bohemia. This settlement of Moravians had been formed in I 722. "Herrnhut," the name which they gave to it, signifies " the watch of the Lord." By 1727 the settlement had a population of five hundred, and public notice had been attracted to them in England a year or so before the arrival of John Wesley. Count Zinzendorf, who regarded Wesley as a pupil, spent much time in England, and died in Chelsea in I 760.

When Wesley arrived at the settlement there were about a hundred dwellings, an orphan house, and a chapel. Here he heard Christian David, the founder of the settlement, who five years before had guided the first missionaries to Greenland. It was his success-though a mechanic without education, never having seen a Bible until he was twenty years old, and to that time a bigoted Roman Catholic-which prepared Wesley at a later period to estimate at their proper relative value the itinerant evangelist full of zeal and spiritual power, and the student, cold, reserved, dialectical, strong in the letter, but weak in the spirit.

While here, Wesley, though much encouraged, was for a time led into a form of mystical antinomianism, and also confounded the witness of the Spirit with sancti-

1 Hutton's " Memoirs," quoted by Tyerman. 
fication. Yet he soon doubted whether the sentiments of his new friends on certain essential points were Scriptural, and was finally constrained to analyze the views and the personal claims of Count Zinzendorf with a frankness which can hardly be distinguished from severity. A painful controversy distracted the minds of those who at first affiliated. The best statement of the change in Wesley's point of view, as the result of acquaintance with the Moravians, is to be found in "John Wesley," by Julia Wedgwood: "Adherence to the church was no longer the first condition of membership in any society with which he was associated. The birthday of a Christian was already shifted from his baptism to his conversion, and in that change the partition-line of two great systems is crossed."

There had been, in various parts of London and vicinity, certain societies, small assemblies, consisting chiefly of members of the Established Church, who met in private houses, and frequently took their name from the house in which they were held. Such was the one in Aldersgate Street where Wesley had found spiritual rest. On his return from Germany Wesley went to and fro, speaking in these societies wherever he could obtain a hearing, and naturally became the most influential among them.

About this time, George Whitefield, who had been preaching in America, returned and sought a meeting with Wesley. He had already attained an extraordinary reputation, and had begun to speak in the open air. Wesley had difficulty in adapting himself to that method, and in referring to the subject said: "I could scarce reconcile myself to this strange way of preaching in the fields, to which he [Whitefield] set me the example on Sunday, having been all my life till very lately so tenacious of every point relating to decency and order that I should 
have thought the saving of souls almost a sin if it had not been done in a church."

Wesley's recent return from Georgia contributed greatly to the number of his hearers, of which he took advantage, proclaiming the gospel according to his new views with unparalleled energy and unction. Although not allowed a second time in the churches, the first message was always effective in the illumination of some hearers.

In defending himself for holding services in the open air he says: "Be pleased to observe: (I) That I was forbidden as by a general consent to preach in any church (though not by any judicial sentence) for preaching such doctrine; this was the open, avowed cause; there was at that time no other, either real or pretended, except that the people crowded so.

(2) That I had no desire or design to preach in the open air till after this oppression."

For such preaching Charles Wesley was cited to Lambeth and threatened by the Archbishop of Canterbury with excommunication. Though somewhat intimidated, encouraged by Whitefield, he preached the very next Sunday at Moorfields ${ }^{1}$ to ten thousand, and at two other points on the same day.

From this time Wesley preached almost incessantly. Every morning he read prayers and preached, reading and expounding the Scriptures also in one or more of the societies every evening; on Monday, Tuesday, Wednesday, and Friday in several contiguous places; on Saturday in the afternoon; on Sunday in the early morning, again at eleven, at two, and at five, traveling many miles between these services. His brother Charles and several others were following a similar order.

1 A district outside the wall of old London used for recreation. The ground is now occupied by Finsbury Square and adjacent streets: 
In England Wesley and Whitefield had not entered into the discussion of doctrinal opinions. But while in the colonies the latter became acquainted with Calvinistic ministers of equal learning and ability, who recommended to him the study of the Puritan divines, with the result that he embraced their doctrines with ardor. He wrote to Wesley upon the subject, who replied opposing the doctrine of election, and also affirming the doctrine of "Christian perfection," teaching that "Christians cannot, indeed, be freed from those perilous weaknesses and follies sometimes improperly termed sins of infirmity, yet that it is the privilege of all to be saved entirely from $\sin$ in its proper sense, and from committing it."

The correspondence, while revealing the intensity of the excitement among the people, and the stern earnestness of these godly men, also displays their sincerity and conscientiousness. Whitefield, in a letter to Wesley, says: "The more I examine the writings of the most experienced men, and the experiences of the most established Christians, the more I differ from your opinion about not committing sin, and your denying the doctrines of election and the final perseverance of the saints. . . God himself teaches my friends the doctrine of election. Sister $\mathrm{H}$ hath lately been convinced of it; and if I mistake not, dear and honored Mr. Wesley will hereafter be convinced also. Perhaps I may never see you again until we meet in judgment; then, if not before, you will know that sovereign, distinguishing, irresistible grace brought you to heaven."

To this Wesley responded:

"MY DEAR BRother: I thank you for yours of May 24th. The case is quite plain. There are bigots both for predestination and against it. God is sending a message to those on either side, but neither will receive it unless 
from one who is of their own opinion. Therefore for a time you are suffered to be of one opinion and I of another."

Again Whitefield wrote:

"I know not what you may think, but I do not expect to say indwelling sin is destroyed in me till I bow my head and give up the ghost. . . Besides, dear sir, what a fine conceit is it to cry up perfection and yet cry down the doctrine of final perseverance! But this and many other absurdities you will run into because you will not own election, and you will not own election because you cannot own it without believing the doctrine of reprobation. What, then, is there in reprobation so horrid? I see no blasphemy in holding that doctrine, if rightly explained. If God might have passed by all, he may pass by some. . . . If you go on thus, honored sir, how can I agree with you? It is impossible. I must speak what I know. By spring you may expect to see

$$
\begin{aligned}
& \text { "Ever, ever yours, } \\
& \text { "George Whitefield." }
\end{aligned}
$$

Finding himself opposed whenever he preached free grace, and the people helplessly divided, Wesley delivered his famous sermon entitled "Free Grace," and published it in a pamphlet of twenty-four pages, annexing a hymn by his brother entitled "Hymn of Universal Redemption."

The circumstances were these which led Wesley to take a public attitude against the doctrine of election: In one of the London societies an advocate persisted in debating it in the meetings held for growth in grace, and Charles Wesley, who was in charge, forbade him to be admitted. When his brother arrived the disputant appeared and demanded if he had been excluded for his opinion. "Which opinion?" asked Wesley. "That of election. I 
hold that a certain number are elected from eternity, and they must and shall be saved, and the rest of mankind must and shall be damned." He told Wesley that others in the society so believed, to which Wesley replied that he never questioned their opinions; all he demanded was that they should "only not trouble others by disputing about them." But the contentious brother answered: "No, but I will dispute about them. You are all wrong, and I am determined to set you right." Under these circumstances Wesley replied: "I fear your coming with this view will neither profit you nor us."

The school at Kingswood had, in a certain sense, been founded by Whitefield, who had laid the corner-stone, but immediately left the institution to the management of Wesley, who bought the ground and paid for the building, partly through the contributions of his friends, and partly from the income of his fellowship. He employed John Cennick as teacher, and authorized him to read and expound the Bible to a society which Wesley gathered in the neighborhood.

Cennick, however, publicly attacked in that society the Arminian views of Wesley. He also wrote many letters to Whitefield, and demanded of Wesley that he and his adherents be allowed to retain their membership and have the privilege of "meeting apart." This resulted in a division of the society, fifty adhering to Cennick and ninety to Wesley. Cennick and his friends declared that they were expelled for holding the doctrine of election. Wesley retorted that they knew that was not the case, as there were predestinarians in the societies in London and Bristol, nor did he " ever yet put any one out of either because he held that opinion." It was this division and the continued controversy which led Wesley to preach against the doctrine publicly. 
In I 740 Whitefield wrote to Wesley:

“ MY DEAR BROTHER: For Christ's sake, avoid all disputation. Do not oblige me to preach against you; I had rather die."

But on his return to England in $174 \mathrm{I}$ he published a pamphlet which contained a letter from Wesley, who complained against this, remarking that if Whitefield was constrained to bear his testimony on the general subject, he might have done it by issuing a treatise without calling his name in question; that he had, however, said enough of what was wholly foreign to the question to make an open, and, he feared, an irreparable breach. He then proceeded to show him how easy it would be for him to answer Whitefield, but that he would not do so. Wesley affirmed subsequently that " those who believed universal redemption had no desire to separate, but that those who held particular redemption would not hear of any accommodation, being determined to have no fellowship with men who were in such dangerous errors; so there were now two sorts of Methodists-those for particular and those for general redemption."

Into the controversy all bodies of dissenters were drawn, and in it many members and ministers of the Church of England participated. Whitefield was more bitterly attacked than Wesley, and all opponents of Methodism united in the prediction that this dispute would soon bring to an end the "fanatical schism."

Whitefield preached against the Wesleys by name in Moorfields, and when invited to the "Foundry," with Charles Wesley sitting near, he introduced the subject and protested against their teaching. He was temporarily so unpopular that his congregations during the week numbered less than three hundred. At all times, however, 
thousands heard him on Sunday. Such were his eloquence, simplicity, and fervor that his popularity fully returned. The personal estrangement between him and Wesley fortunately lasted but a short time.

From that time forward those who sympathized with Whitefield consorted, being aided by the Countess of Huntingdon, whose wealth, social standing, and liberality were such as to assist greatly in the establishment of Calvinistic Methodism. She helped to build sixty-four chapels in different parts of the kingdom, and gave away more than a hundred thousand pounds, selling her jewels and devoting the proceeds to chapel-building and other religious work.

Prior to the formal separation of Wesley and Whitefield many little societies had been formed, but, being left without superintendence, most of them dissolved. Peter Bohler recommended the formation of one in London. By January, 1739, it numbered sixty, and met in Fetter Lane in connection with the Moravian Church, with which several of its members were finally incorporated.

In the summer of 1739 a Methodist society was formed in Bristol, where were already several little societies, which now united. A similar movement took place in Kingswood; another in Bath. Wesley places the time when the first of the united societies was formed toward the close of the year I 739. "From that time he distinguishes what he sometimes designates the United Societies, and at other times the United Society, from all other religious associations with which he had been previously connected." 1

The Fetter Lane society was practically formed by Peter Bohler, who prepared its constitution. But serious differ-

1 " Centennial of Wesleyan Methodism," by Thomas Jackson, president of the Wesleyan Conference (American edition, G. Mason \& T. Lane, New York, 1839). 


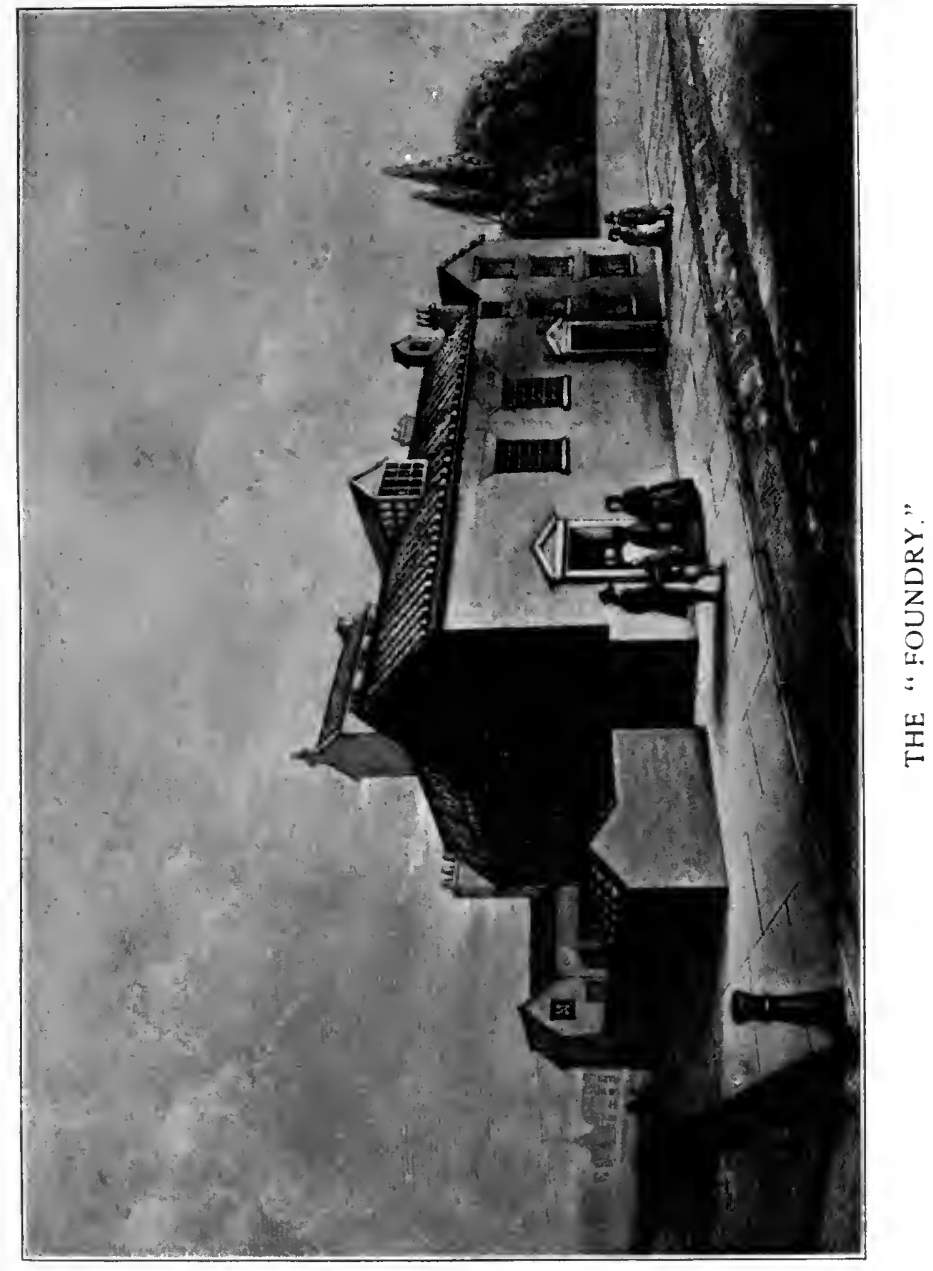




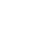


ences arose, some of the members denouncing the Christian ministry as an institution, some opposing all ordinances, and others affirming that silence was the best substitute for the means of grace. Finally, on Sunday, July 6, I 740, Wesley read to the society his objections to these errors, and, being resisted, departed, accompanied by a score of the members, followed later by fifty more, including most of the women.

Eight months previous to this Wesley had secured a building in Moorfields formerly used for the casting of cannon, and had opened it for regular public worship November II, 1739. 'Though this was eight months before he separated from the Moravians, many have spoken of it as the beginning of organized Methodism.

Wherever the Wesleys had traveled while affiliating with the Moravians they had formed " men bands " and " women bands," afterward subdivided according to whether the members were married or single. They were to meet punctually at least once a week, sing and pray, and speak in order, revealing the true state of their souls, confessing to one another their faults in word and deed and their various temptations. To each band was assigned a leader, whose duty it was to describe his own state and then call upon the rest. Wesley met all the men every Wednesday evening, and the women on Sunday. He proposed, also, that one evening in the quarter all the men, on a second all the women, should meet, and on a third men and women together. The last he called love-feasts.

Some objected on the ground that these meetings were man's invention. Wesley replied: "They are prudential helps, grounded on reason and experience, in order to apply the general rules given in Scripture according to particular circumstances." Others affirmed that the bands were "mere popery." Wesley responded with severity: "Do they not yet know that the only popish confession is the con- 
fession made by a single person to a priest? . . . Whereas that we practice is the confession of several persons conjointly, not to a priest, but to each other."

These bands did not, as many suppose, give rise to the classes. The class-meeting in Methodism preceded. Wesley was talking with several of the society in Bristol concerning the means of paying its debts, when one said: "Let every member of the society give a penny a week till all are paid." Another answered: "But many of them are poor and cannot afford to do it." Then said the proposer of this method: "Put eleven of the poorest with me, and if they can give anything, well; I will call on them weekly; and if they cannot give anything I will give for them as well as for myself. And each of you call on eleven of your neighbors weekly, receive what they give, and make up what is wanting."

In the working of this plan, which proved most efficient, the leaders reported to Wesley that they found certain persons "who did not live as they should." He called together all the leaders and instructed them to make particular inquiry into the behavior of those whom they saw weekly. This was the germ of the modern class-meeting, which in process of time incorporated all those elements of the bands which were in practice found to be useful.

As the number of societies increased it became necessary to supply them with preachers. The first lay preacher was Thomas Maxfield, his appointment being made in the absence of Wesley, who was disposed to condemn it, but afterward withdrew his opposition. The second was Thomas Richards, and the third Thomas Westell. Some of these early lay preachers displayed great ability, among them John Nelson; another, Thomas Olivers, became famous both as a preacher and as a poet of high order.

Separate places of worship were now essential, because 
these clergymen were excluded from the churches of the Establishment, and because lay preachers were in no case allowed to conduct services therein, and also on account of the great number of their converts. The first chapel erected by the Wesleys was in Bristol; but prior to its completion the "Foundry" was opened in London. Chapels rapidly followed in Leeds, Manchester, Liverpool, London, Birmingham, and the chief towns of the kingdom.

The success of the movement under the Wesleys was so wonderful that during the year I742, John, the acknowledged final authority, was employing twenty-three itinerant lay preachers and several local preachers; the distinction being that the former gave their entire time to the work, while the latter pursued ordinary business, preaching at such points as they could reach from their places of abode.

The opening of the year I 744 wore a calamitous aspect. It was a time of war. Reports were set afloat that the Methodists were in collusion with the papal Pretender, that Wesley was a Jesuit, an Anabaptist, a Quaker, and that he had been prosecuted for " unlawfully selling gin."

A proclamation was issued in London requiring all Roman Catholics to leave the city. Wesley stayed behind to show that he was not one, but was summoned before the authorities and made to take the oath of allegiance to the king, and to sign a declaration against popery. Charles Wesley was indicted because in a public prayer he had besought God to "call home his banished ones," which was interpreted to mean the House of Stuart.

Wesley's "Journal " shows that in scores of places the Methodists were mobbed while holding services in the public streets and at their own houses. In some towns rioting lasted for a week, and the sufferings of the early martyrs were paralleled. Frequently parish ministers promoted the mobs, and magistrates were not willing to pro- 
tect the Methodists. The natural passions of converted men of giant strength were roused, and it was with difficulty that the Wesleys could maintain order among their followers by beseeching them not to be overcome of evil, but to overcome evil with good.

The conduct of John Wesley was so consistent, his moral power so great, that he was worth more to his followers than a band of armed men. At Newcastle, where the mob spirit was rising, he preached in the public square from the text, "Ye shall be hated of all men for my name's sake." Tradition says that every word was uttered in a tone of command as difficult to resist as if it came from the lips of the greatest general upon the field of battle. Wesley, in his usual laconic manner, states of one such scene that he "found a great mob, and after spending an hour in taming them, exhorted them for two hours more." The ringleaders promised to make no further disturbance. The next day, however, the people, having heard a false report of a victory of the British over the French, gave themselves up to drunkenness and renewed the attack.

In Bristol, Nottingham, and throughout all Cornwall similar scenes took place. Wesley attended service in the Church of St. Ives, and heard the Methodists denounced as "enemies of the church and state, Jacobites and papists."

The announcement of his text was often sufficient to comfort the flock. When he came to a town where the society was broken up, and met the minister fleeing from a mob led by the mayor, he immediately addressed the frightened people from these words: "Enter into the rock, and hide yourselves as it were for a little moment, until the indignation be overpast."

This was the general condition; but opposition met and conquered in the Christian spirit contributed to the increase of the societies. 
On the $25^{\text {th }}$ of June, 1744, the first Methodist conference was called in London. There were present John and Charles Wesley; John Hodges, rector of Wenvo, in Wales; Henry Piers, vicar of Bexley, who had been led by Charles Wesley into the light; Samuel Taylor, vicar of Quinton; and John Meriton. Besides these there were four lay preachers-Thomas Maxfield, Thomas Richards, John Bennett, and John Downes. The participants in the conference applied themselves to determining and defining repentance, saving faith, justification, sanctification, free will, the witness of the Spirit, and other doctrines. The conclusions reached, together with the general proceedings, were recorded in the form of minutes. Some almost prophetic statements are found therein, such as: "We believe the Methodists will either be thrust out or will leaven the whole church." Practical questions of permanent importance were raised, such as: "Is it lawful to bear arms?" and "Is it lawful to use the law?" There was a Quaker element in the societies inclined to deny the first of these, and a Moravian element disposed to question the second; but after debate both were decided affirmatively. Another conference was called in Bristol in 1745 ; subsequently these were held annually.

In 1747 Wesley visited Ireland, where Thomas Williams, a lay preacher from England, a few months before had established a society which had increased until it then numbered three hundred. members. The arrival of Wesley promoted the work, and he found it necessary again to visit that country in 1748 . The Irish Roman Catholics, with their customary violence, attacked the Methodists. Grand juries "presented " Charles Wesley as a vagabond and a disturber of her Majesty's peace, and the appearance of John was the signal for the gathering of mobs.

Before 1758 he had visited every part of Ireland except 
Sligo, and in that year entered this region, where he found a colony of German origin. During the reign of Queen Anne one hundred and ten families from the Palatinate had settled in the town of Court Matress and neighboring hamlets. Being without a minister, they had become notorious for immorality and irreligion; but Methodists had effected a reformation.

Wesley delivered several discourses in a "preachinghouse" in the center of Court Matress, and was. so much pleased with the order and superior morality of this and two neighboring communities that he declared that three such towns could hardly be found elsewhere in England or Ireland, and exclaimed: "How will these poor foreigners rise up in the day of judgment against those that are round about them!" Thus, regardless of the nationality of those to whom the gospel was preached, the Word of the Lord had free course, and was glorified; until, when the twenty-first conference was held at Manchester, August 20 , I 765 , it was deemed advisable to publish the minutes, which had been regularly taken, but not given to the public. They contain the names of the preachers admitted on trial, the stations, helpers, and circuits, with all the appointments, and rules of discipline for both societies and preachers. There were at that time 25 circuits with 7 I preachers in England, 4 with 4 preachers in Scotland, 2 with 2 preachers in Wales, and 8 with 15 preachers in Ireland; making 39 circuits and 92 lay itinerants, besides the local preachers, the Wesleys, and those clergymen of the Church of England that coopperated with them.

The doctrines taught by Wesley and his itinerant and lay preachers included the fundamental principles of Christianity as held by the Reformed churches generally, but excluded ritualism and sacramentarianism, and divided from Calvinism on unconditional election, predestination, final 
perseverance of the saints, and kindred doctrines. In opposition to these it affirmed that notwithstanding human depravity a measure of free will is restored to all together with that supernatural light which "lighteth every man that cometh into the world"; and that those who have been truly converted may fall away and be finally lost.

Specific emphasis was also placed on the possibility of instantaneous conversion, and on the witness of the Spirit, which was explicitly defined and inculcated as the privilege of every believer. The doctrine of Christian perfection-not a perfection which does not admit of a continual increase, but a freedom from sin, from evil desires and evil tempers, and from pride; "the sum of which is the loving God with all our heart, mind, soul, and strength; . . . that all the thoughts, words, and actions are governed by pure love "-was constantly taught; also that it was not usually, if ever, attained at the moment of conversion, that it is attainable by faith and that only, and that its attainment is possible in this life.

The conditions for membership were few and simple, yet they contained a standard of spiritual life and conduct to which comparatively few Christians in any age have attained. The General Rules of the United Societies, stating these conditions, were issued May I, I 743, and signed by John and Charles Wesley; and few changes have been made. ${ }^{1}$ The peculiar institutions for the promotion of the Christian life and the exercise of discipline were the regular itinerant ministry in the form of circuits, involving constant change, and covering a vast extent of country by uniting in one plan regular itinerants and local preachers; the classes, with their leaders and the authority reposed in them; the bands and their leaders; the district meetings and conferences; love-feasts and watch-nights. Members

1 See Appendix I. 
of the societies were instructed to receive the holy communion at parish churches, and in their own meetings when it was administered by one of those regularly ordained ministers of the Established Church who coöperated with the Wesleys. Dissenters connected with the societies were allowed to receive the Lord's Supper at the altars of their respective religious bodies, as, during this period, both John and Charles Wesley and their coadjutors of the Church of England constantly declared that they did not cherish the purpose of forming a new sect or church. This fact accounts for various restrictions and requisitions which no church in Christendom would have thought it wise to impose, and the absence of various provisions essential to a church. Neither ministers nor members, accused of unsoundness in doctrine, defectiveness of experience, inefficiency, or immorality, had the privilege of a trial, much less of an appeal, but were excluded by the exercise of the judgment of the founder. Nor could they complain against this, since none were obliged to remain, and all had accepted his teachings with that definite understanding.

The observance of watch-night originated at Kingswood, where the depraved colliers spent the last night of the year in drunken revels and bacchanalian scenes. The converts to Methodism changed these meetings into religious festivals. Some advised John Wesley to put an end to them, to make the breach greater between the old and the new life, and to prevent occasional disorders. He took the matter under consideration and replied: "Upon weighing the thing thoroughly, and comparing it with the practice of the ancient Christians, I could see no cause to forbid it. Rather I believed it might be made of more general use; so I sent them word that I designed to watch with them on the Friday nearest the full moon, that we might have light thither and back again. I gave public notice of this 
the Sunday before, and, withal, that I intended to preach; desiring they, and they only, would meet me there who could do it without prejudice to their business or families. On Friday abundance of people came. I began preaching between eight and nine, and we continued until a little beyond noon of night, singing, praying, and praising God."

Wesley later declares: "Exceeding great are the blessings that we have found therein. It has generally been an extremely solemn season, when the Word of God sunk deep into the heart, even of those who till then knew him not." To the charge that it was only the novelty of the thing he replied: "Be it so; however, the impression then made on many souls has never since been effaced. Now, allowing that God did make use of novelty or any other indifferent circumstance in order to bring sinners to repentance, yet they are brought. And herein let us rejoice together."

During this entire period Charles Wesley was the coadjutor and counselor of the founder; a religious poet of the first order, a preacher of amazing eloquence and force, though much more variable than his brother. Many of his hymns were improvised while preaching; others were written for special occasions and by John Wesley were set to music. The enthusiasm of Methodists made them the finest singers in the kingdom.

In 1738 , before their conversion, in the technical term, they had published a book of selections, which included some original hymns; the next year two, the following year one, and in 1742 another, in which most of the hymns were by Charles Wesley. Whatever subject disturbed the public mind, his prolific muse took up, and a hymn or a poem was the result. In 1749 a collection of hymns and sacred poems in two volumes was published, with the name 
of Charles Wesley alone as the author. Many thousands singing marvelously fervent descriptions of religious experience in every stage from conviction to the highest attainments of Christian life-the whole sustained by a framework of doctrine. rigorously clear and logical in definition, expressed in vigorous English-produced an effect hardly second to that of the preaching. It was alike instructive and inspiring, afforded the materials for maintaining services in the absence of preachers, and attracted many to the meetings who would never have been drawn to hear any minister, however renowned.

An incidental benefit, the value of which it is difficult to overestimate, was that Methodists committed the hymns to memory, thus enriching their vocabularies by the language and poetic similes, and especially by the spiritual and pathetic terms with which they abounded, so that they were able to speak and pray with astonishing eloquence.

Through life Charles Wesley suffered from ill health, which, in the opinion of Dr. Whitehead, the physician of the family, was the result of the asceticism of his early days. He was of great use to his brother, especially in counteracting his natural credulity and warning him against a tendency to believe fair promises, religious words, and deferential manners. Without the characteristics of leadership, he was yet so strong in High-church feeling that on various occasions, if his views had prevailed, the growth of Methodism would have been checked, and little more than an invisible influence would have descended to future generations.

The most useful and in all respects the most extraordinary accession to Methodism was Jean Guillaume de la Fléchère, a native of Switzerland, a student of philology and philosophy, a master of French, German, Latin, Hebrew, 


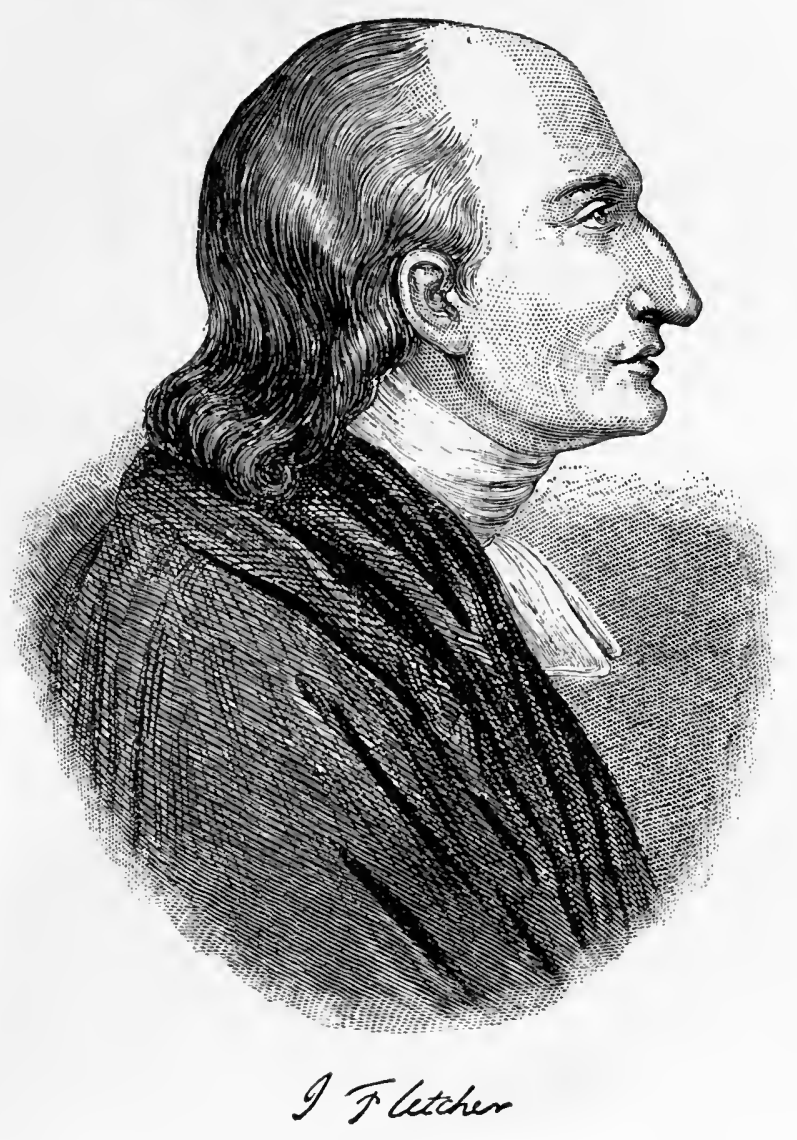


$$
\text { . }
$$ 
and Greek, educated at Geneva, and intended for the ministry, but choosing the army because he was unable to subscribe to the doctrine of predestination. At twenty years of age he enlisted with the rank of captain, under the Portuguese flag. About 1755 he united with the Methodist Society, and in two years was ordained in the Church of England, becoming in 1760 rector of Madeley, where he equaled, if he did not surpass, the brothers Wesley in zeal, fidelity, liberality, and self-denial. He affiliated with the Countess of Huntingdon, and became president of a theological seminary established by her, but resigned on account of doctrinal differences. Subsequently he espoused the cause of Mr. Wesley. This devout man became an ascetic. "He lived on vegetables, and for some time on milk and water and bread; he sat up two whole nights in every week for the purpose of praying, reading, and meditating on religious things; and on other nights never allowed himself to sleep as long as he could keep his attention to the book before him." $\mathrm{He}$ afterward acknowledged the error of this course. About the time of his ordination, determining to spend his days in England, he Anglicized his name, calling himself John Fletcher. Southey ${ }^{1}$ speaks of him as " a saintly man, carrying on the work of controversy with correspondent candor and distinguished ability." By the sweetness of his spirit he was of immense advantage to John Wesley, defending him when he could not defend himself, and exerting a much-needed influence in the direction of universal charity and caution. The testimony of Southey is not open to the charge of exaggeration: "Fletcher of Madeley was a man of whom Methodism may well be proud, as the most able of its defenders; and whom the Church of England may hold in honorable remembrance, as one

1 Southey's "Life of Wesley," vol, ii., p. 208. 
of the most pious and excellent of her sons. Fletcher in any communion would have been a saint."

At the Conference of I 766 an imperfect attempt was made to ascertain the number of members; but not until the Conference of I 767 was the task accomplished. It then appeared that there were 22,410 members in the English societies, 280 I in the Irish, 468 in the Scotch, and 232 in the Welsh. 


$$
\text { - }
$$




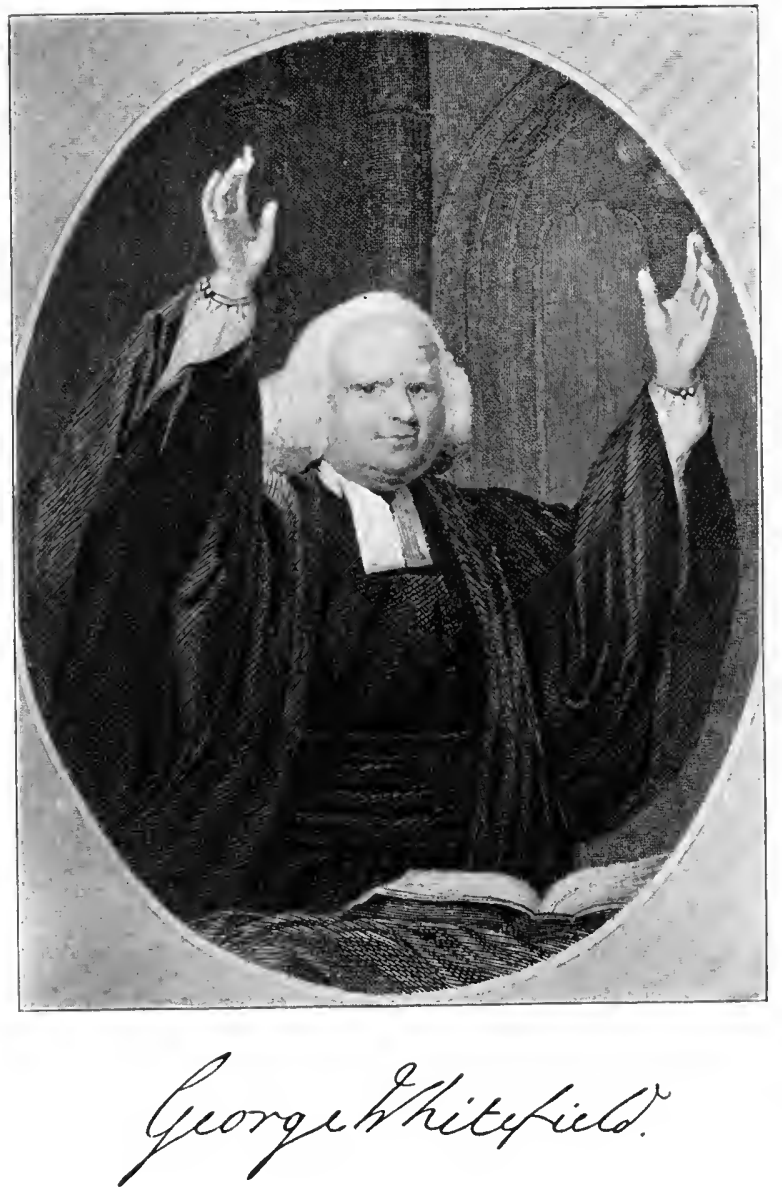




\section{CHAPTER V.}

IN THE NEW WORLD.

As in nature, the soil, the climate, and the culture, no less than the germ, control the growth of every species, so in the formation of civil and ecclesiastical institutions the characteristics, number, and spirit of a people influence development as powerfully as does the initial principle or impulse.

In September, I 739, the natal year of Methodism, George Whitefield arrived in Philadelphia, and during the succeeding year and a half produced the profoundest religious impression, laying the foundations of numerous religious organizations. The influence of Whitefield can be explained in part by the fact that, ten years after this marvelous visit to Philadelphia, that city contained only 2076 houses. Allowing an average of five persons to a family -a large estimate-such was the power of his voice that when he preached in the open air he could easily have commanded the entire adult population.

The first Protestant church in the city of Baltimore was erected during the year I 739. At this time the colony of Pennsylvania had a population of less than 50,000; Virginia not far from 70,000; New Jersey a little over 50,000, of whom nearly one tenth were slaves; and the province of New York is estimated at 65,000, with an annual rate of increase of a thousand. The settlement and development of the country progressed irregularly, being stimulated or retarded by local circumstances and political and pecuniary complications in England. 
In 1750 a census of New England showed 340,000, and of South Carolina, 64,000. The methods of disseminating intelligence throughout the country were chiefly by the few and slow mails, by special messenger, and by conversation. The first newspaper in Connecticut was established at New Haven in 1755 , and the first in North Carolina was published in December of the same year. As late as 1757 the city of New York had but 12,000 inhabitants, and Philadelphia only 1000 more. Delaware had no newspaper until I76I; the city of Providence, R. I., none until I 762. The "Georgia Gazette," the first started in that colony, and the only one for more than twelve years, issued its first number at Savannah in 1763.

In I 764 many German and French Protestants and also English and Scotch, stimulated by bounties in land offered by the legislature, migrated to South Carolina. The same year Pittsburg, Pa., was laid out, and its settlement commenced.

This epitome of the history of the country for the first six years of the seventh decade of the eighteenth century suggests the conditions found by a company of Irish Palatines who sailed from Limerick to the city of New York in I 760. A writer in the "Irish Evangelist," one hundred years later, in an animated and pathetic manner describes their departure. ${ }^{1}$ The chief figure is a young man of thoughtful look and resolute bearing, evidently the leader of the party. "He had been one of the first-fruits to Christ among his countrymen, had been the class-leader of their infant Church, and often in their humble chapel had ministered to them the Word of life. . . . His name was Philip Embury. His party consisted of his wife, Mary Switzer, to whom he was married in Rathkeale Church, on the 27 th of November, I758; two of his brothers and their 1 Stevens's "History of the Methodist Episcopal.Church," vol. i., pp. 51, 52. 
On Christimaf Day; being mondaxy y.25: th of Lecembers, ins the year 1752; the, hhonein to muy loul by a glimpuse of hito Redeerhing lons: biing an zamfest of pry reatimption in hrist. Jescus, to whom be gloy for ever \& iver. Amen.

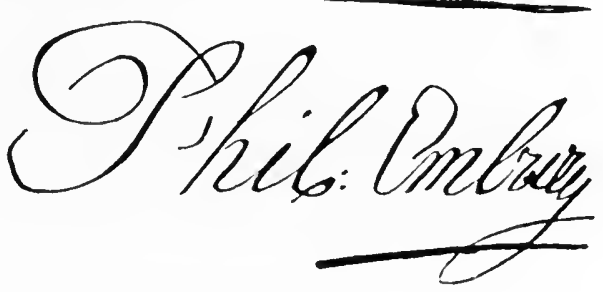

EMBURY'S ACCOUNT OF HIS CONVERSION. 

families; Peter Switzer, probably a brother of his wife; Paul Heck, and Barbara, his wife; Valer Tettler, Philip Morgan, and a family of the Dulmages." The vessel reached New York August I0, I760.

There were doubtless a few other Methodists in the United States, but none had become the nucleus of a Methodist society, or become affiliated with any, with a possible noteworthy exception. Light is thrown upon his age by an ancient record in the possession of his granddaughter, made by Samuel Embury, as follows: " My father, Philip Embury, died in August, I773, aged fortyfive years." At no place in the record can the date of Embury's birth be found, but that of his baptism is given: "Ye 29th of 7ber [September], I 728." As it was the custom in the family to baptize the children when but a few weeks old, his age at the time of his arrival in New York must have been about thirty-two years.

Before sailing for America he was a carpenter, and also served as a Wesleyan local preacher. He had a good education; his orthography was faultless, chirography remarkably clear, and punctuation accurate. The date of his conversion is preserved, and its character may be inferred from a fragment of a manuscript in his own handwriting:

"On Christmas day;-being Monday ye 25th of December in the year $175^{2}$; the Lord shone into my soul by a glimpse of his Redeeming love: being an earnest of my redemption in Christ Jesus, to whom be glory forever and ever. Amen.

$$
\text { "Phil: Embury." } 1
$$

The presumption is that he lived a consistent life and endeavored, at least by his example, to save those who had

1 "Lost Chapters Recovered from the Early History of American Methodism," by J. B. Wakeley, D.D. (New York, Wilbur B. Ketcham, 1889). 
accompanied him from the temptations to which they were exposed; but there is no evidence that he exhibited genuine Methodist zeal or conducted public religious services in the New World for at least six years. Few of those who accompanied him were Methodists, though some writers, more enthusiastic than accurate, have spoken of the arrival of "Embury and a whole ship-load of Wesleyans." The others were members of the Protestant Church in Ireland, but knew nothing of experimental religion as taught by Wesley. In I 765 another vessel landed in New York, containing five families. Some of these were related to Embury, and most of them he knew.

The account of what may be properly termed the outbreak of Methodism in New York is taken from a letter to Dr. Abel Stevens by a reliable authority, Dr. G. C. M. Roberts: "A few of them only were Wesleyans. Mrs. Barbara Heck, who had been residing in New York since I 760, visited them frequently. One of the company, Paul Ruckle, was her eldest brother. It was when visiting them on one of these occasions that she found some of the party engaged in a game of cards. There is no proof, either direct or indirect, that any of them were Wesleyans and connected with Embury. Her spirit was roused, and, doubtless emboldened by her long and intimate acquaintance with them in Ireland, she seized the cards, threw them into the fire, and then most solemnly warned them of their danger and duty. Leaving them, she went directly to the dwelling of Embury, who was her cousin. It was located upon Barrack Street, now Park Place. After narrating what she had seen and done, under the influence of the divine Spirit and with power, she appealed to him to be no longer silent, but to preach the Word forthwith. She parried his excuses, and urged him to commence at once in his own house and to his own people. He consented, 
and she went out and collected four persons, who with herself constituted his audience. After singing and prayer he preached to them and enrolled them in a class. $\mathrm{He}$ continued thereafter to meet them weekly. Embury was not among the card-players, nor in the same house with them."

Wakeley gives some particulars of Mrs. Heck's appeal. When she found Embury she exclaimed,"Brother Embury, you must preach to us, or we shall all go to hell, and God will require our blood at your hands!" Though astonished and alarmed, Embury, to quiet his conscience, inquired, "How can I preach? for I have neither a house nor a congregation." The zealous woman replied, "Preach in your own house and to your own company first." The result was that he consented to preach, and she went forth to gather a congregation.

The interesting question whether Philip Embury was engaged in the game of cards was raised many years ago. Wakeley says: "Some Methodists have admitted it, and the enemies of Methodism have said in ridicule that American Methodism originated at the card-table." He then investigates the subject and furnishes conclusive testimony that Embury was not present. The action of Mrs. Heck shows that he was the only man to whom she could appeal, and justifies Wakeley's remark that "he was a very diffident man, and his not doing was among his darkest deeds."

At this first service, held in 1766 , the month and day being unknown, those present enrolled their names in a class and promised to attend regularly at the house for religious instruction.

Begun under such circumstances, Methodism could but succeed. This small number contained latent forces sufficient to arouse a primitive community dead in trespasses and sins, and to make an impression of some kind upon any 
community; for in a thousand hamlets and towns of Great Britain and Ireland the Word of the Lord had free course, and was glorified.

Soon Embury's house could not hold all who desired to hear, and a larger room was hired, to provide for the expense of which collections were taken. In a few months fourteen or more had been genuinely converted and were formed into classes, one of men and the other of women. The instructions given by Wesley and his helpers to local preachers, and the responsibilities imposed upon such, and also upon class-leaders, show that Embury, who was both a class-leader and a licensed local preacher, understood Methodism, and knew how to organize bands, classes, and societies.

It is not surprising that in the small city, without much to excite the people, with no daily papers to absorb attention by presenting the news of the civilized and the uncivilized world, great interest should have been kindled by such a movement. Even at this late day, notwithstanding all the counter-attractions, a "revival" in a time of peace will attract larger concourses and maintain interest longer than any other public excitement. Besides, Whitefield had preached often in New York only three years before, and Wesleyan Methodism, for a time, undoubtedly derived considerable advantage from the estimate in which he was held, by the affiliation of some of his converts and the familiarity of the public with the name of Methodism, which was popularly applied to his spirit and methods.

The place where Embury preached was not far from the quarters of the British troops. Three musicians of the regiment, drawn by the singing of the Methodists, so much more spirited than the music of the Established Church or of the dissenters, attended the services, were converted, and were commissioned by Embury as "exhorters." The 
poorer part of the community furnished the majority of the converts. The neglected paupers in the almshouse received the attention of the evangelists, and heard with delight the promise of everlasting life. The superintendent of the institution invited Embury to preach there, and, besides several of "the non-criminal wards of the State," was himself added to the list of converts.

The attendance at the meetings constantly increased. Early in 1767, probably in the month of February, a stranger, in military dress and wearing a sword, appeared among them. He was obviously an officer of the royal army, and the few Methodists seem to have been disturbed, perhaps frightened, suspecting that he might have come to question them concerning the conversion of the musicians and other members of the army. But his devout conduct allayed their fears, for he conformed to their methods. At the close he introduced himself as "Captain Thomas Webb, of the king's service, and also a soldier of the cross and a spiritual son of John Wesley," and informed Embury that he had been authorized by Wesley to preach.

Webb was in the siege of Louisburg, where he lost his right eye, and at midnight, September I 2, I 759, was with those who landed at the foot of the tangled ravine below the plains of Abraham, and in the van led by Howe which scaled those heights before dawn, where he fought in the murderous battle of Quebec in the midst of the fiercest carnage, seeing scores of his companions killed, but escaping himself with a wound in his right arm. Five years after that battle he heard John Wesley preach in Bristol, and became a zealous Christian. In I 765 he joined the Methodist Society, and one day entered a Methodist congregation at Bath. The circuit preacher having failed to come, Webb, in his regimentals, advanced to the altar and began to speak, 
rousing deep feeling, especially while recounting the facts of his personal experience. The occurrence was narrated to John Wesley, who immediately licensed him to preach. Webb frequently referred to his hairbreadth escapes, and the manner in which he lost his eye has probably never been paralleled: "A ball hit him on the bone which guards the right eye, and, taking an oblique direction, burst the eyeball, and passing through his palate into his mouth, he swallowed it." The wounded were put into a boat, and all were assisted to the land except Webb. One of the men said, "He needs no help; he is dead enough." But he was just able to whisper, "No, I am not dead." It was three months before he could attend to his military duty. His escape was so narrow- "for had the ball struck him a hairbreadth higher or lower it would have taken his life" - that he felt that in a peculiar manner he owed his life to God. Of his scars he was not ashamed, and over his eyeless socket he wore a green shade. At the time of his arrival in New York he was acting barrack-master at Albany. He loved the Bible to such an extent as to study it in the original Greek, and his Greek Testament is preserved to this day in the United States. Much can be learned of his character by references in the writings of John and Charles Wesley. Some years later the former heard him, and records in his journal his opinion: "I admire the wisdom of God in still raising up various preachers, according to the various tastes of men. The captain is all life and fire; therefore, although he is not deep or regular, yet many who would not hear a better preacher flock together to hear him. And many are convinced under his preaching; some justified; a few built up in love."

Again Wesley says: "Captain Webb kindled a flame here, and it is not yet gone out. The people generally 


were much quickened. I found his preaching in the street at Winchester had been blessed greatly."

Captain Webb was equally successful with the Irish. Wesley wrote: "Captain Webb is now in Dublin; invite him to visit Limerick; he is a man of fire, and the power of God constantly accompanies his word.'

Charles Wesley does not seem to have thought as highly of him, for when John Fletcher and Captain Webb were trying to induce Joseph Benson, the preacher and commentator, to identify himself with the American work, Charles Wesley wrote to Mr. Benson: "I have barely time to say your own reasons for not going to America, and Christopher Hopper's, are unanswerable. Mr. Fletcher is only the captain's echo. The captain's impressions are no more (or very little more) to be depended upon than George Bell's. $\mathrm{He}$ is an inexperienced, honest, zealous, loving enthusiast." Nevertheless he seemed to be fond of the captain, and in a letter to Mr. Rankin two years later he writes: "My love to Captain Webb when you see him."

The "impressions" of which Charles Wesley speaks related to the coming glory of the settlements in the Western Hemisphere, and the corresponding opportunity for the effectual spread of the gospel. The world now knows that it would have been impossible for Captain Thomas Webb, or any other preacher or poet, to prophesy greater things than have come to pass. Joseph Benson, however, waited for a "more effectual call" that never came.

When Captain Webb preached he reverently laid his sword on the table or desk before him. This, as it was probably the only circumstance of the kind the people of this country had ever seen, military men, especially officers, being notoriously indifferent to practical religion, had some effect in attracting the large congregations which gathered 
to hear him. But he was a man of extraordinary eloquence, often compared to Whitefield. He was especially effective with military men, who admired his martial bearing and powerful voice, and he was the means of the conversion of many soldiers and several influential officers. One of these, who became a powerful local preacher, in an account of his conversion, says that he "thought the word of command by such an excellent officer could distinctly be heard throughout the line, from right to left." Written memorials of his discourses attach much influence to his piercing eye, which seemed to scrutinize every listener. But probably the strongest, because the most deliberate and competent, testimony to his powers is that of the first Vice-President and second President of the United States, John Adams, who describes him as "the old soldier-one of the most eloquent men I ever heard; he reaches the imagination and touches the passions very well, and expresses himself with great propriety." 1

The next step was the renting of a room on William Street, known as " the rigging loft," sixty by eighteen feet. Services were held there three times a week, Webb and Embury preaching alternately. Jesse Lee's "History of the Methodists," published in I8Io (p. 25), says: "There are a few persons still living in New York who met with the society in the rigging loft, and are pleased at the recollection of what the Lord did for them in their little society, when they were weak and ignorant in the things of religion, but were united together in Christian love and fellowship."

Captain Webb saw the necessity of permanent accommodations for the Methodists. ${ }^{2}$ He was anticipated in this design by Barbara Heck, who had " made the enterprise a

1 Stevens's "History of the Methodist Episcopal Church," vol. i., p. 60.

2 Ibid., vol. i., p. 62. 


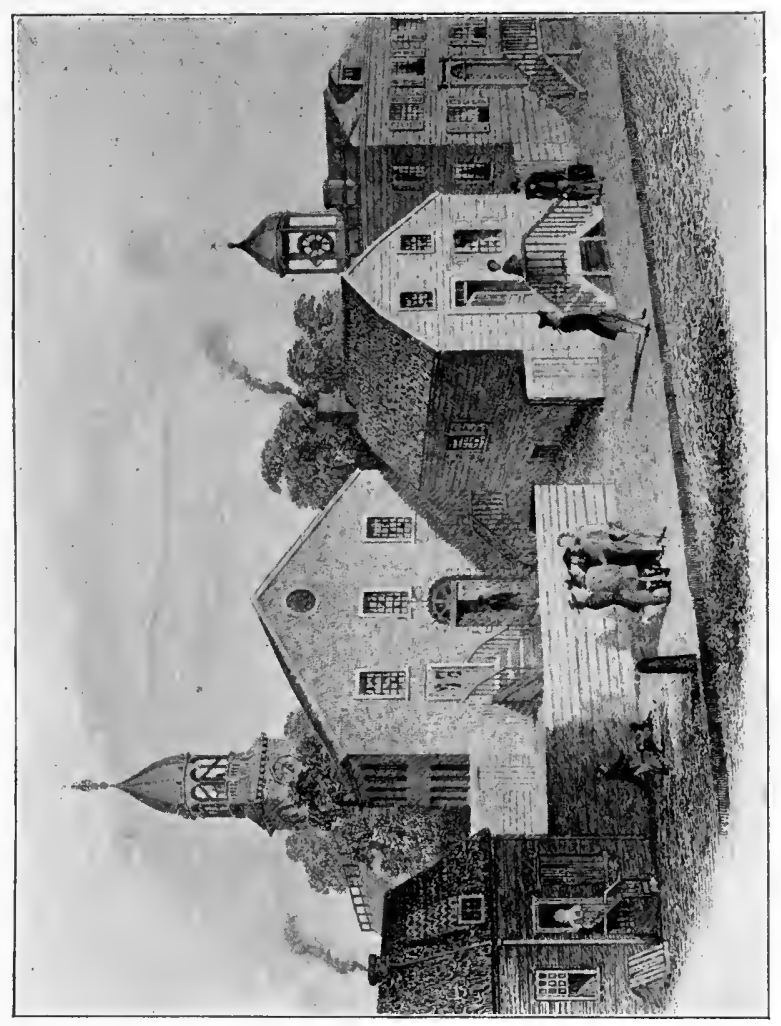

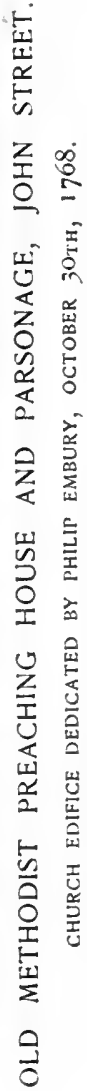


matter of prayer," and testified that she had received from the Lord, "with inexpressible sweetness and power, the answer, "I the Lord will do it.'" She also devised an economical plan for the edifice, which was approved by the society.

Wakeley ${ }^{1}$ doubts whether a house of worship would have been erected at that time without the influence of Captain Webb and the money contributed by him. Dr. Stevens expresses the opinion that it would probably not even have been attempted without his aid; he was the first subscriber, pledging thirty pounds-one third more than any other person gave-nor was his interest exhausted then, for he loaned the society two hundred pounds, and as the enterprise progressed, increased the loan to three hundred, these financial services being rendered in the year I 768. Nor was this all, for he remitted a considerable part of the interest, secured contributions from friends amounting to thirty-two pounds, and sold books for the benefit of the enterprise. Captain Webb was one of the original trustees, though to Embury belongs the glory of being "the first trustee, first treasurer, first class-leader, and first preacher."

In less than three years from its beginning Methodism in the city of New York had made an impression both wide and deep. The society leased the site in John Street in 1768 , purchasing it two years later. The first subscription paper records the results of a successful appeal to the citizens, and contains nearly two hundred and fifty names, including all classes, from the mayor and the primitive Methodists down to African slaves, known only by their Christian names. The most distinguished names in the early history of New York, founders of the great families who have flourished and still exist, the Livingstons,

1 " Lost Chapters," p. I44. 
Duanes, Delanceys, Laights, Stuyvesants, Lispenards, are there, as well as Dr. Samuel Auchmuty, rector of Trinity Church, and his assistant, the Rev. John Ogvelsvie, and the Rev. Charles Inglis, assistant to Dr. Auchmuty and also his successor. Oliver Delancey, Esq., gave six pounds ten shillings. Frederick De Peyster was among the subscribers, also Philip Livingston, one of the signers of the Declaration of Independence. Side by side with these names are those of Margaret and Rachel, two slaves hired to take care of the preacher's house. Among the subscribers are the names of thirty-five women.

The preamble of the paper, to which the signatures of those who contributed were affixed, is an important document, showing that at that time the Methodists had no idea that they would become a distinct denomination of Christians; in fact, their appeal for general support was made upon the assumption that they were not to be.

"A number of persons, desirous to worship God in spirit and truth, commonly called Methodists (under the direction of the Rev. Mr. John Wesley), whom it is evident God has been pleased to bless in their meetings in New York, thinking it would be more to the glory of God and the good of souls had they a more convenient place to meet in, where the Gospel of Jesus Christ might be preached without distinction of sects or parties; and as Mr. Philip Embury is a member and helper in the Gospel, they humbly beg the assistance of Christian friends, in order to enable them to build a small house for that purpose, not doubting but the God of all consolation will abundantly bless all such as are willing to contribute to the same."

The deed, also, to the ground upon which the first preaching-house was built, made to the Rev. Richard 
Boardman and others at the termination of the lease which they had taken when the building was erected, is one of the most important Methodist historical documents extant.

It reads: "TO HAVE AND TO HOLD the said two lots of ground, meeting-house, and premises hereinbefore mentioned and described, and hereby granted and released, with all and every the appurtenances unto the said Richard Boardman, Joseph Pilmoor, William Lupton, Thomas Webb, John Southwell, Henry Newton, and James Jarvis, their heirs and assigns, forever. NEVERTHELESS, UPON SPECIAL TRUST AND CONFIDENCE, and to the intent that they and the survivors of them, and all other trustees for the time being do and shall permit John Wesley, late of Lincoln College, in the University of Oxford, cleark, and such other persons as he, the said John Wesley, shall from time to time appoint, and at all times during his natural life, and no other person or persons, to have and enjoy the free use and benefit of the said meeting-house and premises.

"That the said John Wesley, and such other person or persons as he shall from time to time appoint, may therein preach and expound God's Holy Word; and after his, the said John Wesley, deceased, upon further trust and confidence, and to the intent that the said trustees and the survivors of them, and the trustees for the time being, do and shall permit Charles Wesley, late of Christ's Church College, Oxford, cleark, and such person or persons as he shall from time to time appoint, and at all times during his life, and no other, to have and enjoy the full use and benefit of the said meeting-house and premises for the purposes aforesaid; and after the decease of the survivors of the said John Wesley and Charles Wesley, then upon further trust and confidence, that the said Richard Boardman and the rest of the hereinbefore mentioned trustees, or the major part of them, or the survizors of them, and the major part of the 
[Chap. v.

trustees for the time being, shall, and from time to time, and FOREVER thereafter will, permit such person or persons as shall be appointed at the yearly conference of the people called Methodists in London, Bristol, Leeds, and the city of New-York aforesaid, and no others, to have and enjoy the said premises for the purposes aforesaid, provided always that the said person or persons so from time to time to be chosen as aforesaid, preach no otherdoctrine than is contained in the said John Wesley's Notes upon the New Testament and his four volumes of Sermons; and upon further trust and confidence, that as often as any of the trustees hereby appointed, or the trustees for the time being, shall die or cease to be a member of the society commonly called Methodists, the rest of the said trustees for the time being, as soon as conveniently may be, shall and may choose another trustee or trustees, in order to keep up such a number of trustees that they may in no time hereafter be less than seven nor more than nine."

The trustees bought the material and transacted business for the building in their own names and on their personal securities. Embury, skilled in carpentry, labored on the structure, constructing its pulpit with his own hands. The province being under the régime of Great Britain, dissenters were not allowed to build churches in the city of New York; the Established Church not only had the right of way, but in its behalf obstructions of various kinds were placed in the by-paths which others were attempting to traverse.

The building was of stone, sixty feet by forty-two. It was necessary to have a fireplace and chimney so as to evade the law, which prohibited the erection of "regular churches" not under the jurisdiction of the Church of England. Wakeley informs us that at first there were no stairs or breastwork to the galleries, the hearers ascending by a 


$$
\text { 党 }
$$


. 
ladder; and even the seats on the lower floor had no backs; nor were there class-rooms, lecture-room, chorister, or choir.

On the thirtieth day of October, 1768 , Embury ascended the pulpit which he had constructed, and preached the dedicatory sermon from Hosea x. I2: "Sow to yourselves in righteousness, reap in mercy; break up your fallow ground: for it is time to seek the Lord, till he come and rain righteousness upon you." Lee states that the house was sufficiently large to hold twelve or fourteen hundred. This does not agree with Stevens, who says that "within two years from its consecration we have reports of at least a thousand persons crowding it to the area in its front." It was named Wesley Chapel, and Dr. Dixon, an eminent Wesleyan, says: "This was most likely the first chapel called by his name, for most assuredly John Wesley would never allow either chapel, society, or anything else to be called after him in England so long as he lived and possessed the power to prevent it." In I 770 a parsonage was erected adjacent to the chapel. The city of New York then contained twenty thousand inhabitants.

After his retirement with full pay as captain, Webb had leisure to do what he would. Relatives of his wife residing at Jamaica, Long Island, he removed to that place, hired a house, and preached in it, and "twenty-four persons received justifying grace." He made many preaching-tours through New Jersey, and on his first visit to a town formed a class, and on the second or third organized a society. It was he who planted Methodism in Pemberton, at Trenton, the capital of the State, and Burlington. In the lastnamed he preached in the market-place and in the courthouse, and there Joseph Toy, one of the early settlers of New Jersey, was led to become a Christian and to identify himself with the Methodists. Appointed by his "spiritual father" the leader of a small class, he became first a local 
and then a traveling preacher, giving twenty-five years to the work, and becoming one of the teachers in the first college established by Methodists. If Philip Embury founded Methodism in New York, Captain Webb was no less its founder in Philadelphia. Here he preached in a sail-loft and formed a class of seven members. It was he, also, who introduced Methodism into Delaware, and he was equally successful whether preaching in Wilmington or among the farmers and fishermen on the banks of the Brandywine River. He also lifted up his commanding voice with wonderful effect in Baltimore.

His services to American Methodism were no less on the other side of the Atlantic. He constantly appealed to Wesley to send out preachers, and in 1772 returned to England, chiefly, if not wholly, to interest Wesleyans in the work of God in the colonies.

For some years it was generally supposed that the name of Barbara Heck was Hick, that she died in New York and was buried in Trinity Churchyard, and that Paul Hick, one of the early trustees of the John Street Church, was her son. Against this it was maintained that her name was not Hick, but Heck; that with her husband and sons she removed to Camden, N. Y., in 1770 or 1771 , and thence to Canada in 1774 ; that she died in 1804 , and is buried by the side of her husband in the burying-ground of the old "Blue Church in the front of Augusta"; that Paul Hick, of New York, was a nephew of Paul Heck, the husband of Barbara, and that the change of name was made in his family.

The documents submitted in the "Christian Guardian," Canada, May 25, I859, and in the "Christian Advocate," together with much other proof, determine the case beyond reasonable question. Dr. J. B. Wakeley ${ }^{1}$ supported 


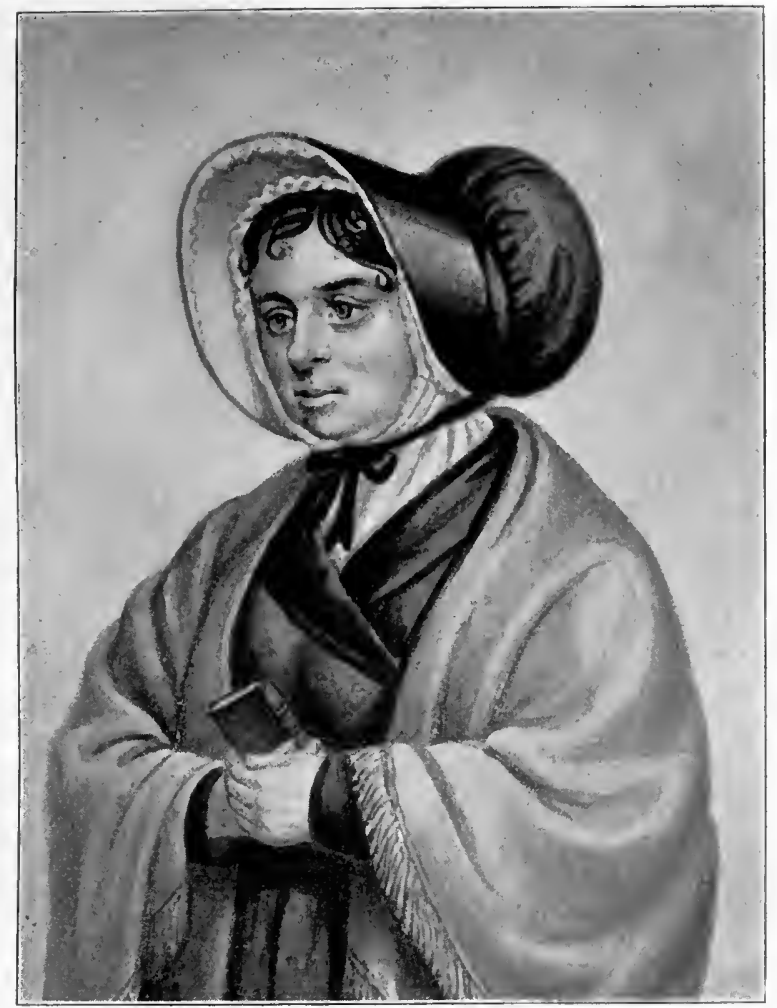

BARBARA HECK. 
the view that makes the orthography of the name Hick and that represents Mrs. Heck as being buried in Trinity Churchyard, New York; but he addressed a communication to the "Christian Advocate" which showed that he was inclined to doubt the correctness of his previous opinion. The evidence that she migrated with Philip Embury from the city of New York to Camden, N. Y., and that her name was Heck, is, as to the latter point, that the signature of Paul Heck is plainly Heck, that the Irish authorities agree that this was the spelling of the name, and that William Case, perhaps the best authority in Canadian Methodist history, wrote to Nathan Bangs in I 855 that he had visited the descendants of Paul Heck and his worthy companion at their residence in Canada. Prompted by correspondence with one of the descendants to make an independent investigation, the writer was led to the same conclusion reached by Dr. Stevens, that the name of this modern Deborah was Heck, and that she died in Canada.

While Embury and Captain Webb were preaching in New York, a religious awakening of which they had never heard was spreading in Maryland. Robert Strawbridge, a native of County Leitrim, Ireland, had migrated to North America in the hope of securing for his family a better support, and settled in Frederick County, Maryland, on Sam's Creek, then strictly a backwoods country. Five years before, the Indians passed Forts Cumberland and Frederick, plundering and murdering, and continued unchecked until within eighty miles of Baltimore, which so terrified the inhabitants that the women and children were placed on board vessels in the harbor, while the residents of the surrounding country were fleeing to Baltimore for safety. ${ }^{\text {I }}$

1 William Hamilton's " Early Methodism in Maryland, Especially in Baltimore" ("Methodist Quarterly Review," July, 1856). 
It is maintained by some that Robert Strawbridge preached the first sermon, formed the first society, and built the first preaching-house for Methodism in Maryland, and in America, at least three years before Wesley Chapel, in John Street, New York, was erected. In support of this view Bishop Asbury's "Journal" is quoted (vol. iii., p. 27): "Here Mr. Strawbridge formed the first society in Maryland-and America." This is not sufficient to settle the question, as there is a letter in Asbury's own handwriting in possession of Dr. George R. Crooks, of Drew Theological Seminary, in which Asbury states that Methodism was established in this country in about I770. This is plainly an error; and in the haste and hard work of Asbury various statements were made which are incorrect. But the most remarkable document on this point is quoted in full by Hamilton, and certified as having been written by David Evans, son of John Evans, one of Strawbridge's first converts. The attestor is Samuel Evans, son of David. "John Evans, born 30th of November, 1734, about five miles from Baltimore. When about fourteen years of age his father moved to the upper part of Baltimore County, near the neighborhood of Pipe and Sam's Creek, where he resided until his death. In his twentyfifth year he married; he had nine children, and six are now living. His parents were members of the Church of England. About the year 1764, he embraced the Methodist religion under Mr. Strawbridge." The remainder of the note consists of a statement that when the first circuit was formed in Baltimore County, Mr. Evans offered his house; it was accepted about the year I 768, and continued a preaching-house upward of forty years, during which time he was a regular class-leader. The phrase "about the year I 764 " is too vague to settle the question.

Asbury and Coke prepared the first "Discipline" in 1785 , 
in which is a short account of Methodism. After reciting the services of Philip Embury and Thomas Webb, the history proceeds: "About the same time Robert Strawbridge, a local preacher from Ireland, settled in Maryland, and, preaching there, formed some societies." But whatever was true, in the opinion of Asbury, about the first sermon, he explicitly says in another place: "The first Methodist church in New York was built in I 768 or I 769." Jesse Lee doubtless had as wide a personal acquaintance and as many opportunities for information as any one of his time. He says:" "Not long after the society was formed in New York, Robert Strawbridge, from Ireland, who had settled in Frederick County, in the State of Maryland, began to hold meetings in public, and joined a society together near Pipe Creek."

Much depends upon the date of the arrival of Strawbridge in Maryland, and this it is difficult if not impossible to determine, as he began in a section which did not admit of the prompt circulation of intelligence. Strawbridge's course in Ireland, considered in connection with his temperament, renders it improbable that he would long remain in this country without lifting up his voice. In his native land he was an itinerant, but provoked a storm of opposition and persecution which not long after his conversion compelled him to remove to the county of Sligo. There "his labors were signally blessed of God through a considerable district." He preached also in the county of Cavan. Aged Methodists yet living in Ireland recall descriptions of his oratory which they heard from the lips of their parents and grandparents.

As to the exact date of his emigration to this country, John Shillington, Esq., whom Dr. Stevens describes as the 
best Irish authority on the Methodist history and antiquities of his country, says it was not earlier than 1764 or later than I 765. The presumption of Strawbridge's priority would be strong if it were not more than counteracted by the authority of Pilmoor, Garrettson, Lee, Henry Boehm, and George Bourne. Dr. John Atkinson, in "The Beginnings of the Wesleyan Movement in America," exhaustively discusses this question, furnishing cumulative and convincing proof that American Methodism began in New York.

On Sam's Creek Strawbridge built a log chapel. It was twenty-two feet square, without windows, door, or floor, and, though long occupied, was never finished. Beneath its rude pulpit he buried two of his children. Like Captain Webb, he was a traveler, and extended his labors into eastern Delaware, Pennsylvania, and Virginia. The Sam's Creek society soon gave four or five preachers to Methodism. Strawbridge founded the first Methodism in Baltimore and Harford counties, and the first native preacher of the continent, Richard Owen, was one of his converts. Wherever he went he raised up preachers. Substantial citizens as well as the more excitable part of the community responded to his efforts. Thomas Bond, of Harford County, father of the Rev. J. W. Bond and of the noted Thomas E. Bond, M.D., was one of many who became Methodists under his rousing appeals. Some have spoken of Strawbridge as of meager talents and limited education. While he had little learning derived from the schools, he was not ignorant in any sense which would expose him to contempt or excite levity, and possessed more than usual ability in important respects.

Though little has come down to the present time concerning his personal characteristics, fortunately one witness, Freeborn Garrettson, preëminently competent to estimate his powers, has described him. Nathan Bangs, in 
his "Life of Garrettson," extracts an account of an evening which the latter spent with Strawbridge: "Mr. Strawbridge came to the house of a gentleman, near where I lived, to stay all night. I had never heard him preach, but as I had a great desire to be in company with a person who had caused so much talk in the country, I went over and sat and heard him converse till nearly midnight, and when I retired it was with these thoughts: 'I have never spent a few hours more agreeably in my life.' $\mathrm{He}$ spent most of his time in explaining Scripture and in giving interesting anecdotes." 1

The society in New York continued to prosper, and Thomas Taylor, one of the original lessees of the si:e of the Methodist preaching-house in John Street, wrote to John Wesley, on the IIth of April, I768, an important letter, in which, after describing Mr. Whitefield's first, second, and third visits, and the reaction which followed, he says: "The above appears to me to be a genuine account of the state of religion in New York ten months ago, when it pleased God to raise up Mr. Embury to employ his talent (which for several years had been hid, as it were, in a napkin) by calling sinners to repentance, and exhorting believers to let their light shine before men." After giving particulars of the work and vividly describing its reinforcement by the arrival of Captain Webb, he mentions his own arrival in the United States on the twentysixth day of the preceding October, and his forming the acquaintance of Embury and others. He states that Embury " lately has been more zealous than formerly, the consequence of which is that he is more lively in preaching, and his gifts as well as graces are much increased"; and "for six weeks past our house would not contain half the people." He then details plans for erecting a chapel, and says :

1 Bangs's "Life of Garrettson," p. 28 (New York, 1839). 
"There is another point far more material, and in which I must importune your assistance, not only in my own name, but also in the name of the whole society. We want an able and experienced preacher, one who has both gifts and graces necessary for the work." $\mathrm{He}$ commends the work accomplished by the preaching of Captain Webb and Mr. Embury, but discriminatingly adds: "Although they are both useful, and their hearts are in the work, they want many qualifications for such an undertaking; and the progress of the gospel here depends much upon the qualifications of preachers. In regard to a preacher, if possible we must have a man of wisdom, of sound faith, and a good disciplinarian; one whose heart and soul are in the work; and I doubt not but by the goodness of God such a flame will be soon kindled which would never stop until it reached the great South Sea."

Mr. Taylor informs Wesley that they could not purchase such a preacher as he described, though they might make many shifts to evade temporary inconveniences, and thus pathetically appeals to him, "Dear sir, I entreat you, for the good of thousands, use your utmost endeavors to send one over." He suggests that the preacher would do well to sail from Boston, Liverpool, or Dublin in the month of July or August, as in that case he would have fine weather and probably arrive in September.

The closing sentences of this letter exhibit a spirit which would win success and put to shame the luxurious apathy of many an idle minister: "With respect to money for the payment of the preachers' passage over: if they could not procure it we would sell our coats and shirts to procure it for them. I most earnestly beg an interest in your prayers, and trust you and many of our brethren will not forget the church in this wilderness." 1

1 Bangs's "Life of Garrettson," pp. 16-20. 
Others wrote to Wesley begging him to send preachers, among them Captain Webb and Thomas Bell, "a humble mechanic who had worked six days on the new chapel;" and by private correspondence the news of the progress of Methodism on this side of the Atlantic had been circulated among members of the English Wesleyan societies, some of whom had been contemplating crossing to identify themselves with the new country, but had hesitated, not willing to relinquish their associations. These made preparation to sail, and Robert Williams, a local preacher whose zeal was fired by the accounts, applied to John Wesley for authority to go over and preach. This was given on the express stipulation that when the regularly commissioned missionaries to be sent by Wesley should arrive, he would labor under their direction. Williams besought his friend Ashton to emigrate with him, and on hearing that he would go, sold his horse to pay his debts, and, carrying his saddle-bags on his arm, started for the ship with a loaf of bread and a bottle of milk, but no money for his passage. Ashton paid the expenses of both, and in due time they landed in Norfolk, Va.

Williams, who was primitive in his character and methods, at once began to preach. We are indebted for what is known of Mr. Williams's work in that city chiefly to Wakeley's "Lost Chapters," and to an old book found among the early remains of Methodism in New York, which appears to have been kept after the method of Boswell, Johnson's ideal biographer. Everything that transpired, great and small, was recorded, so that the reader is introduced to Mr. Williams in every possible capacity. The trustees paid for his hat- "a beaver hat"-for his cloak, for his trunk, for his physician, his barber's bill, his letter-postage, and for his horse-keeping. The bills for these necessities were sent to the trustees, and thus came to be recorded in the 
book. These accounts parallel in method those kept by the early Congregational churches of New England, where the number of glasses of liquor drunk by some of the installing councils are recorded in connection with the names of the persons who drank them.

There is extant, in Williams's handwriting, a "love-feast ticket" dated October I, I 769. It was one of the first given in this country, and, according to a tradition in the family, the figures represent the number of members of the society at that date.

\section{"Psalm I 47. I I. Oct. I. I 769.}

"The Lord taketh pleasure in them that fear him: in those that hope in his mercy.

"Hannah Dean.

"RobT. Williams.

$$
\text { "N. York." }
$$

An entry in Wesley's " Journal," under date of Friday, October I4, I 768 (vol. iv., p. 293), illustrates the catholicity of the Methodist movement, the conglomerate character of the first settlers of this country, and the fraternity which existed between evangelical Christians: "I dined with Dr. Wrangel, one of the king of Sweden's chaplains, who has spent several years in Pennsylvania [who had been engaged in preaching to Swedish Americans]. His heart seemed to be greatly united to the American Christians; and he strongly appealed for sending some of our preachers to help them, multitudes of whom are as sheep without a shepherd."

In the "Journal" of John Wesley ${ }^{1}$ the twenty-sixth conference, at Leeds, is mentioned under date of August

1 Vol. iv., p. 312, American edition. 


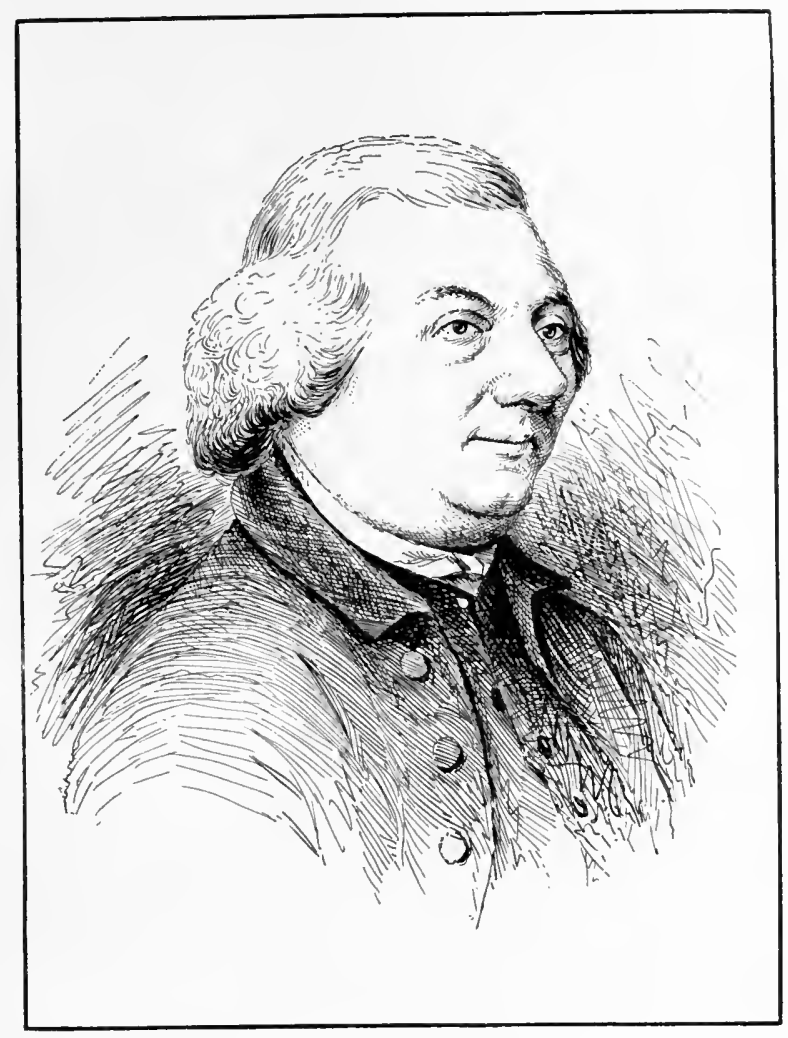

RICHARD BOARDMAN. 
Ist, and part of the record runs: "On Thursday I mentioned the case of our brethren in New York, who had built the first Methodist preaching-house in Anerica, and were in great want of money, and much more of preachers. Two of our preachers, Richard Boardman and Joseph Pilmoor, willingly offered themselves for the service; by whom we determined to send them fifty pounds, as a token of our brotherly love."

Richard Boardman was a native of Ireland, thirty-one years of age, and for six years had been employed by Wesley as a traveling preacher. Joseph Pilmoor at sixteen had been converted by the preaching of Wesley, and was educated by him at the Kingswood school ; after his admission to the conference he had traveled four years in Cornwall and Wales.

Wesley gave them twenty pounds for their passage, and within two weeks after their appointment they were ready to sail. Notwithstanding they had taken the advice of Mr. Taylor as to the time of sailing, the voyage lasted nine weeks, and it was not until October 2 Ist that they landed at the village of Gloucester Point, on the Delaware, six miles below Philadelphia.

Dr. Wrangel, the Swedish missionary, had written to Philadelphia that Wesley had appointed two missionaries, and they were welcomed by the society and Captain Webb. Pilmoor began his mission in the United States without delay, preaching from the steps of the old State House on Chestnut Street. Ten days later he addressed the following letter to Wesley:

“Philadelphia, October 31, 1789.

"REv. Sir: By the blessing of God we are safely arrived here, after a tedious passage of nine weeks. We were not a little surprised to find Captain Webb in town, 
and a society of about one hundred members, who desire to be in close connection with you. 'This is the Lord's doing ; it is marvelous in our eyes.'

"I have preached several times, and the people flock to hear in multitudes. Sunday evening I went out upon the common. I had the stage appointed for the horse-race for my pulpit, and I think between four and five thousand hearers, who heard with attention still as night. Blessed be God for field-preaching! When I began to talk of preaching at five o'clock in the morning the people thought it would not answer in America; however, I resolved to try, and I had a very good congregation." 1

Boardman, after preaching several times to increasing congregations, journeyed on horseback to New York. Passing a barrack-supposed to have been in Trenton-he inquired of a soldier if there were any Methodists there, and was answered, "Yes, we are all Methodists; that is, we would be glad to hear a Methodist preach." A Presbyterian church was secured, and the ringing of the bell at an unusual hour called together a large concourse, to whom an impressive sermon was preached, the effect of which was permanent, though attended with considerable excitement at the time, on account of the unusual circumstances.

Boardman began his mission in New York in the John Street Church. On the 4th of November he wrote to Wesley that only a third part of those who attended could obtain entrance, the rest being glad to hear from without. This letter states that the church contained "about I 700 people." This is undoubtedly a typographical error for 700 . A remarkable sentence in the letter is: "Oh, may the Most High now give his Son the heathen for his inheritance!

1 Bangs, " History of the M. E. Church," vol. i., p. 62. 
The number of blacks that attend the preaching affects me much."

Boardman usually preached four times a week; and met the society on Wednesday night. He was allowed his board, and for clothes sixty dollars a year, paid quarterly. Early in his ministry John Mann was converted, and became a preacher of wide usefulness.

A peculiar method was adopted by Boardman and Pilmoor in distributing their labors. Three times a year-in the spring, summer, and autumn-they exchanged between Philadelphia and New York, the winter term lasting five months. From both these cities in the beginning they made long excursions.

Whitefield arrived in Philadelphia the last day of November, I769, and gave his blessing to Boardman and Pilmoor. Less than one year afterward he died of asthma in Newburyport, having preached his last sermon at Exeter, N. H., where, carried away by his emotions, he prolonged his discourse through two hours. "It was the last of that series of mighty sermons which had been ringing like trumpet-blasts for thirty years over England and America." At Newburyport the people gathered about the house just as he was attempting to ascend to his chamber. Exhausted as he was, his heart went out toward them, and, pausing on the stairs, he exhorted them. "His voice, never, perhaps, surpassed in its music and pathos, flowed on till the candle which he held in his hand burned away and went out in the socket. The next morning he was not, for God had taken him." To him while time shall last must be given the credit of introducing the spirit of Methodism into the New World. Wondrously did he prepare the way for Wesley's missionaries.

Pilmoor reported to Wesley in the spring of 1770 that 
in New York the pious of most congregations came to hear them; that the religion of Jesus had become a favorite topic in that city; that the society consisted of about a hundred members besides probationers; that Boardman and himself could not go much into the country, as they had more work in the cities than they were able to perform. He called for two more brethren, assuring Wesley that " they need not be afraid of wanting the comforts of life; for the people are very hospitable and kind." $\mathrm{He}$ added that when he and Mr. Boardman came they put themselves and the brethren to great expense, but the situation was different, and now everything necessary was provided.

Robert Williams by this time had gone South and was coöperating with Strawbridge. John King came from London to America late in I 769, and his connection with the Methodists appears to have been made with the society in Philadelphia, where he declared that he had been called of God to preach the gospel. As he had no license from Wesley, nor any recommendation from the preachers in England, Lee informs us that he could not be admitted. Undaunted, however, he set up an appointment for himself in the potter's field, where members of the society heard him; and being convinced that he was sincere, able, and zealous, they induced Pilmoor to allow him to preach a trial sermon, after which he was licensed and sent to Wilmington, Del., " to exhort among a few people who were earnestly seeking the Lord."

He proceeded to Maryland, where marked success attended his labors in 1770 . In a sermon at the Forks of Gunpowder, in Baltimore County, men of decided character were converted, among them James J. Baker, who organized a class and opened his house for the entertainment of preachers and for worship. Later the third Methodist chapel in Maryland was erected upon his estate. 
One of his sons, who occupied an official position in Baltimore, was the first convert of King's ministry in that city. His first pulpit was a blacksmith's block in the street; his next, a table. That occasion being a militia training-day, a drunken crowd upset the table and threw him down; but the commander of the troops restored order, and King preached so powerfully that he was invited to speak in St. Paul's Church. Like the founder of Methodism under similar circumstances, "he improved that opportunity with such fervor as to receive no repetition of the courtesy." The record is that he used his stentorian voice to its utmost capacity; that "he made the dust to fly from the old velvet cushion." Wesley wrote to him: "Scream no more, at the peril of your soul. God now warns you by me, whom he has set over you. Speak as earnestly as you can, but do not scream. Speak with all your heart, but with a moderate voice. It was said of our Lord, ' He shall not cry;' the word properly means he shall not scream. Herein be a follower of me, as I am of Christ. I often speak loud, often vehemently, but I never scream. I never strain myself; I dare not; I know it would be a sin against God and my own soul. . . Y Your last letter was written in a very wrong spirit. If you cannot take advice from others surely you might take it from your affectionate brother."

Notwithstanding Pilmoor's statement to Wesley that he and his colleague were chiefly confined to the cities, within a year the pressing calls for help led him out into the country. In the summer of 1770 he was aiding Strawbridge, Owen, King, and Williams in Maryland.

There is no reference to America in Wesley's lists of appointments until 1770, when the names of Pilmoor, Boardman, Williams, and John King appear. Captain Webb was still in the colonies, continually appealing to 
Wesley for more preachers. In I 77 I they reported three hundred and sixteen members. Wesley, though in a sea of troubles growing out of the separation of the Calvinists from the Arminians, said to the conference: "Our brethren in America call aloud for help. Who are willing to go over to help them?" Five offered, of whom but two could be spared.

Francis Asbury was one of these, son of an English farmer and gardener, whose wife, a diligent reader, having lost her daughter, became intensely religious, training her remaining child as only a pious mother who had centered all her affection upon a son could do. When but seven years of age he was an interested reader of the Bible. At thirteen and a half he began to learn a trade. Before he was fourteen he was awakened by the conversation of a man not a Methodist, and had the opportunity of listening to the noted Calvinistic Methodists, and of reading their books, especially the sermons of Whitefield. Wherever the Methodists appeared, whether Arminian or Calvinistic, their preaching was the innocent occasion of inciting violence, which increased to such an extent as to place "the whole region in a state little short of civil war." "Broken relics of ruined furniture are still kept in Methodist families of the county [Staffordshire] as sacred mementos of those days of the fiery trial of their fathers." 1

Francis Asbury went to Wednesbury to attend their services, where he was surprised to hear prayers and sermons delivered without notes or books, and was impressed by the devotion of the people. He fell under deep conviction, and when praying with a companion in his father's barn he had an experience which he records in these words: "I believe that the Lord pardoned my sins and justified my soul."

1 Stevens. 
He began to hold meetings, led a class, then preached, but, because of diffidence, it was some months after he preached before he publicly prayed in Methodis $\imath$ meeting-houses. His intelligence, fidelity, and zeal being manifest to all, he was licensed as a local preacher, and after acting for some years in that capacity while pursuing his business, when he was between twenty-one and twentytwo years of age he consecrated himself wholly to God and his work.

He had never left his ministerial work to attend the Annual Conference during the five years that he had been a traveling preacher, but had been thinking two months before this session "that America was destined to be his field of labor."

Wesley discerned in him qualities eminently fitted for leadership. His parents, though sorrowing on account of the parting, did not oppose his going, his mother especially recognizing the hand of God. He sailed from Bristol on the $4^{\text {th }}$ of September, I 77 I, the money for his expenses having been provided by Methodists, who gave him clothes and ten pounds. He preached as often as possible on the voyage, and spent his leisure time "in prayer, retirement, and reading." 1 The books that Asbury was reading were Sellon's "Answer to Elisha Cole on the Sovereignty of God," Mr. De Renty's Life, part of Mr. Norris's Works, Mr. Edwards on "The Work of God in New England," "Pilgrim's Progress," the Bible, Mr. Wesley's " Sermons," and Fletcher's "Appeals." Richard Wright, his companion, was comparatively unknown, and had been in the ministry but one year. They reached Philadelphia, Oc-

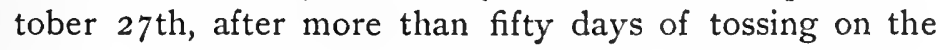
sea.

Dr. Bangs estimates that at this date there were about 1 "Asbury's Journal." 
six hundred Methodists in the colonies, and at least ten preachers besides Wesley's missionaries.

The night after Asbury's arrival in Philadelphia he attended service and listened to Pilmoor, who preached in an edifice still in existence, which was built by a German Reformed society and sold in I 770 to Miles Pennington, one of the members of the class formed by Captain Webb two years previously. Though Asbury does not speak specifically of preaching, he says: "I felt my mind opened to the people and my tongue loosed to speak." A watch-night service was held November 4th. Pilmoor preached, and "very few left the solemn place till the conclusion. Toward the end a plain man spoke, who came out of the country, and his words went with great power to the souls of the people."

That Asbury had preached several times is to be inferred from the fact that when about to set out for New York he records that he preached at Philadelphia his last sermon, November 6th, and adds that "this also was a night of power to my own and many other souls."

He preached in the court-house, in Burlington, N. J., and on the way thither met with "one P. Van Pelt," who had heard him preach in Philadelphia, and invited him to accompany him to his house on Staten Island, where he preached, reaching New York on Monday, the I2th. Here he met Richard Boardman, who was not well, and after consultation, having doubtless had an understanding to that effect with Wesley, Asbury assumed the practical control of the work; and his "Journal" recounts the exercise of the energy, decision, and method which characterized his subsequent work. He expresses regret that both he and Boardman should remain in New York; affirms that he had not yet the thing which he sought-a circulation of preachers to avoid popularity and partiality; that he ex- 


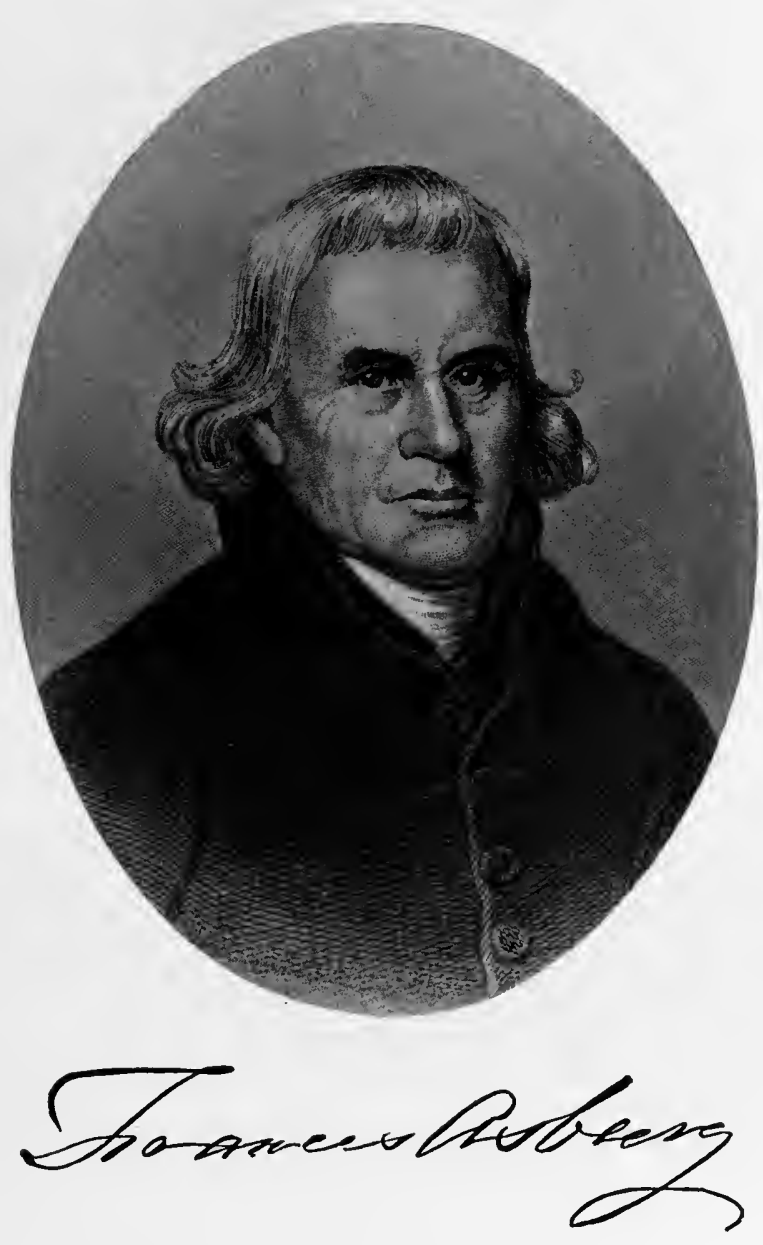



pected trouble; that the brethren seemed unwilling to leave the cities, but he would set the example; that he was determined that no man should bias him with soft words and fair speeches.

$\mathrm{He}$ went to Westchester on the 24th, tiventy miles from New York, and was permitted by the mayor to preach in the court-house, which he did morning and afternoon, conducting a meeting at West Farms in the evening.

The strong affection existing between Methodists at that early day led to singular entries in "Asbury's Journal." November 7 th, in Philadelphia, he met Peter Van Pelt for the first time. Less than two months afterward he records: "From this I went to my old friend V. P.'s, who received me with his former kindness."

From the time of his arrival in this country Francis Asbury seemed to be singularly liable to various forms of disease, and his "Journal " abounds with descriptions of numerous attacks, and of the medical treatment to which he was subjected. He traveled and preached constantly, having exciting adventures. Wherever there was a jail he visited it, preaching when permitted. Reactions from extreme Calvinism were among the principal impediments he had to encounter anong the intelligent. The Friends treated him kindly, as did many of the Presbyterians. On a certain Friday he " dined with Mr. R., who cannot keep negroes for conscience' sake."

Though courageous, occasionally a man-fearing spirit paralyzed him. Of such a case he says, "I have nothing to plead to palliate my omission of prayer," and implores the forgiveness of God. Whenever possible he preached on the occasion of executions. At Chester, $\mathrm{Pa}$., when four prisoners were to be hanged, John King preached and Asbury prayed. 
After extended tours in the Middle States he met Captain Webb and Mr. Boardman in Philadelphia. Boardman was nominally superintendent, and prepared a plan of labor covering several succeeding months: Boardman was to go east as far as Boston, Pilmoor to Virginia, Richard Wright to New York, and Asbury to remain three months in the vicinity of Philadelphia. By these means it was proposed to distribute the labors of seven preachers over as many hundred miles. Asbury methodically arranged his routes over a circuit having Philadelphia as the center, and reaching as far northward as Trenton, N. J. Three months later the plan was reconstructed by Boardman, who located himself in Philadelphia and Asbury in New York.

Scarcely an event of importance occurred without Asbury's availing himself of the occasion. He preached two or three times every day, and yet often accused himself of a lack of zeal, and blamed his spiritual condition for a want of life when his bodily strength was exhausted or weakened by disease. Sometimes he recognized the cause of his depression, as appears from this entry: "My mind was greatly depressed. Not on account of any outward, known $\sin$; but partly from the state of my body, and partly from the deep sense of the very great work in which I am employed."

In December of the same year, while in Kent County, Md., he urged Robert Williams to proceed to Virginia, and Pilmoor to penetrate as far south as possible. Among other important centers which the latter reached was Savannah, and the descendants of those whom he led to Christ are to this day in active coopperation with Methodism.

On the Ioth of October, I772, Asbury received a letter from Wesley appointing him "assistant or superintendent." Wesley's method in England was to call the cir- 
cuit preachers helpers, and the superintendents of circuits, assistants.

While he was in Kent County a minister of the Church of England demanded by what authority he preached. Asbury informed him that he was one of Mr. Wesley's preachers. Said the clergyman: "I have the sole authority over this people, and the care of their souls, and you can not and shall not preach; if you do I will proceed against you according to law." Asbury with dignity informed him that he had no respect for his assumed authority; that he came there to preach, and should do so. Said the clergyman, "You will create a schism and draw the people from their work." "Do not fairs and horse-races hinder the people?" said Asbury. Then said the clergyman, "What is the real object of your coming?" "To turn sinners to God." "Cannot I do this as well as you?" asked the parson. Asbury then solemnly declared, "I have authority from God;" and added, "I do not preach to invalidate your authority, and I do not wish to dispute with you." But he told Asbury that he had business with him, and became violently enraged. Asbury then began the meeting, and urged the people to repent. The parson remained to hear him, but at the conclusion said to those present that they did wrong in attending. Thus records Asbury: "He said I spoke against learning, whereas I only spoke to this purpose-when a man turns from all sin, he will adorn every character in life, both in church and state." 1

Numerous conversions followed his preaching, as well as that of his colleagues, and the results are well described by Asbury, who never fails to give due credit to those who had preceded him: "The Lord hath done great things for these people, notwithstanding the weakness of the in- 
struments and some little irregularities. Men who neither feared God nor regarded man-swearers, liars, cockfighters, card-players, horse-racers, drunkards, etc.-are now so changed as to become new men; and they are filled with the praises of God. This is the Lord's work; and it is marvelous in our eyes. Not unto us, O Lord, not unto us, but unto thy name be all the glory." 1

Returning from the South in company with John King, and passing among the societies which had been formed on the western shore, he crossed and recrossed the Susquehanna River, coming in Christmas week to the residence of J. Presbury. There he held the first Quarterly Conference of which there is any account. After a sermon the following propositions were considered:

"I. What are our collections? (We find them sufficient to defray our expenses.)

"2. How are our preachers stationed? (Here follow the assignments of Strawbridge, Owen, King, Webster, Rawlings, and Asbury.)

"3. Shall we be strict in our society meetings and not admit strangers? (Agreed.)

"4. Shall we drop preaching in the daytime through the week? (Not agreed to.)

" 5 . Will the people be contented without our administering the sacrament? (John King was neuter, Strawbridge pleaded much for the ordinances, and so did the people, who appeared to be much biased by him. Asbury says that he would not agree to it, but Mr. Boardman had yielded to them at a previous quarterly meeting, and that he was obliged to connive at some things for the sake of peace.)"

Other discussions related to the collections to pay the board and expenses of preachers. Asbury states that they 
examined carefully into the moral character of the preachers and exhorters, and found all what they should be, except one exhorter, and of him "they had great hopes." Strawbridge received forty dollars "quarterage," Asbury and King thirty dollars each.

Asbury now began to record his criticisms of the various preachers, and as he was candid in expressing his opinion in conversation with those concerned, the educational effect of his advice upon the infant church was of incalculable value. Of William Watters he said: "He spoke with great care, but with little depth. He may improve and make a useful preacher in time." "I heard Isaac Rawlings exhort. His exhortation was coarse and loud enough, though with some depth. I gave him a little advice, which he seemed willing to take." 1

Asbury, at the beginning of 1773 , made his headquarters in Baltimore. For some time after the first preacher lifted up his voice in Baltimore there had been no disposition on the part of people generally to open their houses for Methodist meetings or to entertain the preachers. Most of the sermons had been delivered in the markethouse, or on street corners, and the preachers had lodged at taverns or in the country, where adherents were more numerous. Matters in this respect had begun to improve when Asbury arrived, for many converts from the country had moved to the city, and the conviction had grown that Methodism was to be permanently established. Captain Patten, an Irishman, was the first citizen to open his house for the preaching of Asbury.

A sail-loft had been secured for public services, but Methodism had been without a responsible head. Asbury proceeded to " settle the classes," and to establish the order

1 Proper names in those early times were spelled variously. This man's appears as in "Asbury's Journal," and as Rollin, Rawlins, and Rollins. 
and certainty that characterized all institutions founded by John Wesley. Though some chafed under the rigor of the administration, prosperity continued until soon it was necessary to erect a church. This led to the purchase of a lot sixty by seventy-five feet, on the corner of Strawberry Alley and Fleet Street, on which a meeting-house was begun November 17, 1773. Two lots were purchased and a church commenced in Lovely Lane, April I8, 1774. According to Dr. Hamilton, ${ }^{1}$ it is uncertain which was first finished.

Asbury formed for himself a circuit including Baltimore and extending over six counties. It comprised twentyfour appointments, and he traversed it once in three weeks, preaching, exhorting, classifying, and holding quarterly meetings.

Robert Williams was the apostle of Methodism in Virginia. He opened his commission in Norfolk, where he preached with such energy and fire that he was supposed to be insane, and the people were afraid of him; but after his second sermon, their hearts became deeply touched, and they received him into their houses.

He was aided by the Rev. Devereux Jarratt, an Episcopal clergyman, who wrote an account of the revival in Sussex and Brunswick counties, in which he commended the labors of Williams and others. Jarratt, like Wesley, formed the converts into a society, and while he acknowledged the value of the labors of the Methodists to him, they have gratefully remembered and in all their histories recorded his kindness to them. Williams was equally effective in North Carolina.

The manner in which Asbury dealt with men individually must not be overlooked in an exposition of the elements which gave early Methodism its power. In the

1 In the "Methodist Quarterly Review" for 1856 . 


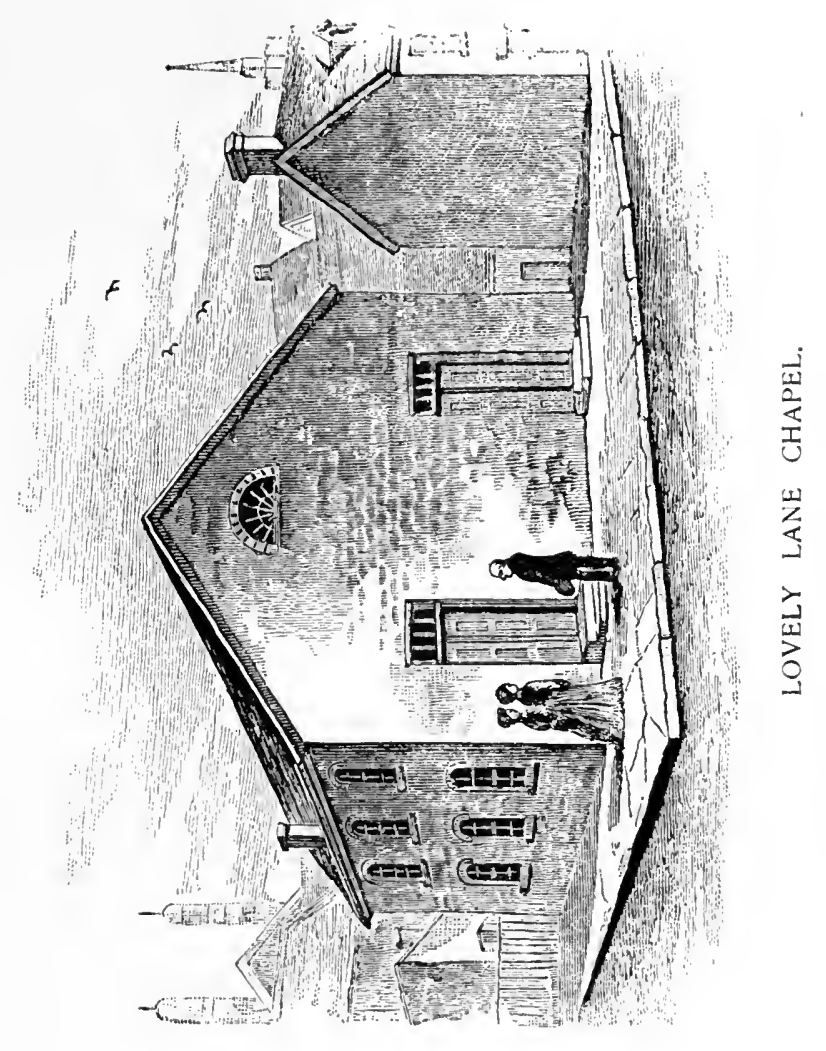




\section{-}


account of his travels through " the Jerseys," he says: "I met with W. B., a man who has a great regard for us, but seems to be too much taken up with worldly cares. But speaking faithfully and closely to him, I showed him the deceitfulness of riches in producing a spirit of independence toward God, hardness of heart, and pride in its various forms, while they promise us safety and happiness."

Following the example and precept of Wesley, Asbury went to the Established Church for the sacraments, and encouraged his converts to do likewise. Frequently the Methodists were insulted by unsympathizing clergymen. In Burlington, N. J., he went to the church in order to receive the sacrament. As he was a man of distinguished presence, and by this time well known, the parson gave a strange discourse "full of inconsistency and raillery." "Leaving him to answer for his own conduct, [Asbury] took no further notice of it, but preached at night from these words: 'The natural man receiveth not the things of the Spirit of God,' and showed first what the things of the Spirit of God are; secondly, described the natural man; and thirdly, showed how they appear to be foolishness to him, and that he cannot know them by the strength of his intellect or acquired abilities." As usual, the tirades of clerical opponents reacted in favor of those whom they endeavored to discredit.

The sky was not everywhere bright. Some of Asbury's colleagues were restless under his strong hand. Richard Wright, Joseph Pilmoor, and others had written to him in a severe tone. Asbury had explained to Wesley the necessity of discipline and of more laborers, imploring him to come himself, and Wesley seems to have contemplated a visit in order that he might understand the true state of things; for Asbury ${ }^{1}$ states that he received a letter from

$$
1 \text { "Journal," May 6, 1773, vol. i., p. } 72 .
$$


Wesley informing him that the time of his coming over to America "is not yet."

Captain Webb had gone to England in I772, after six years' labor in the United States. Wesley heard him, and the captain attended the conference at Leeds, where he urged the appointment of the best men to America.

Thomas Rankin and George Shadford were sent over. The former was a Scotchman, converted under the preaching of George Whitefield, but afterward, hearing John Wesley and Alexander Mather, became a local preacher, and in $176 \mathrm{I}$ an itinerant of rare energy and marked success. For ten years he had encountered opposition, administered Wesleyan discipline with tact and vigor, and preached with impressiveness, increasing and consolidating the societies wherever he went. Among his converts was a curate of the English church.

Mr. Wesley appointed him superintendent of the entire work of Methodism in America, and Rankin chose as his companion Shadford, who had been a soldier, whom he thus describes: "My much-esteemed friend and brother, whose uprightness, piety, and usefulness I had proved on several circuits."

There is nothing in the records of early Methodism which exhibits the sublimity of the conceptions of John Wesley concerning the work and his relation to it more dramatically than his letter to George Shadford: ${ }^{1}$

"DEAR GEORGE: The time is arrived for you to embark for America. You must go down to Bristol, where you will meet with T. Rankin, Captain Webb, and his wife.

"I let you loose, George, on the great continent of America. Publish your message in the open face of the sun, and do all the good you can. I am, dear George,

"Yours affectionately,

$$
\text { "John WESLEY." }
$$

1 Wesley's Works, vol. vii., pp. 99, 100. 


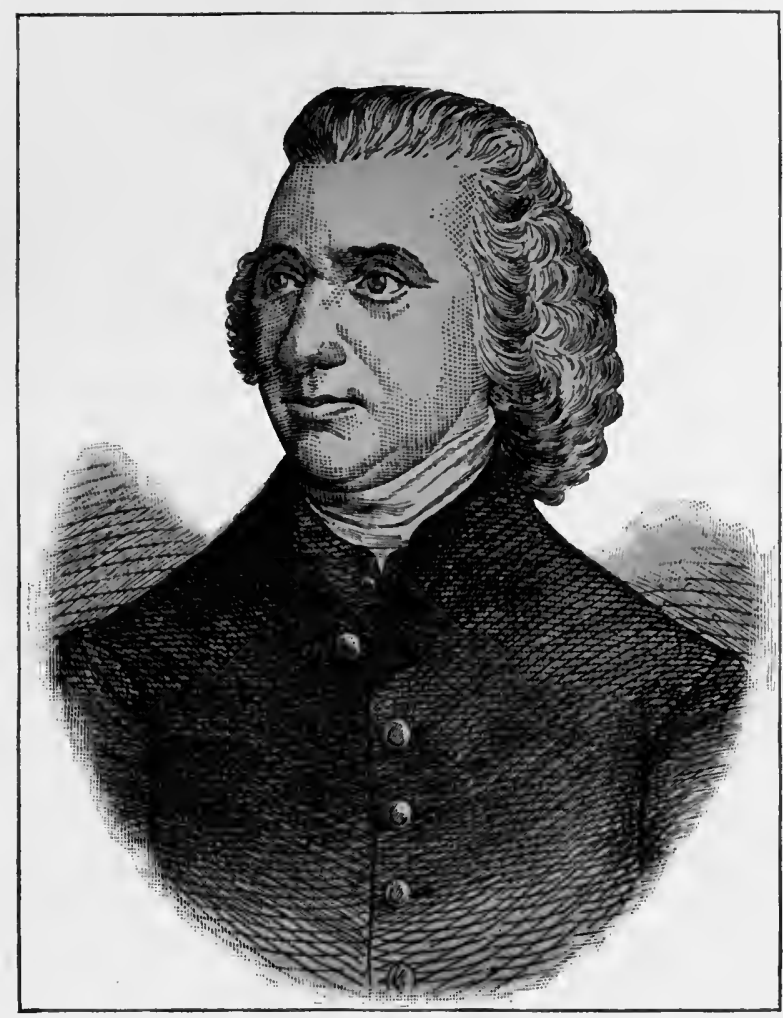

THOMAS RANKIN. 
They sailed on Good Friday, April 9, 1773, accompanied by Joseph Yearbry, an English local preacher.

These two missionaries landed in Philadelphia on the third day of June, and immediately commenced work. When Asbury, on the night after their arrival, heard Rankin from the text, "I have set before thee an open door, and no man can shut it," he wrote: "He will not be admired as a preacher; but as a disciplinarian he will fill his place." Subsequently his entries were more favorable.

Rankin and Asbury arrived in New York the I2th of June, where on the next morning the latter preached. Rankin found so many indications of trouble that he was cast down, but during the preaching of Asbury was much comforted. The text, Ruth ii. 4, "Behold, Boaz came from Bethlehem, and said unto the reapers, The Lord be with you. And they answered him, The Lord bless thee," used in the spiritualizing method then common, suggested a sermon of singular appropriateness. In the afternoon, Rankin, Asbury, Captain Webb, and Wright went to St. Paul's Church and received the sacrament. During the week they separated, Webb going to Albany and Asbury to New Rochelle, where he remained some time, preaching every day and three times on Sunday. On his return to New York on the 23d he found Rankin had been "well employed in settling matters pertaining to the society."

A revival of religion was in progress, characterized by manifestations of fervor and epidemic excitement so unusual that Rankin thought them extravagant. An issue was raised upon this point, the effects of which were far-reaching. When he came to this country, Asbury left prejudices and prepossessions behind, determining thoroughly to identify himself with the people and their institutions. Rankin's ideas of loyalty and government were exhibited in two forms: he magnified authority until those who 
[Chap. v.

thought that Asbury's hand was of iron (though in general he endeavored to prevail by conciliating and compromising wherever principle was not involved) found that of Rankin to be steel. Their differences upon the subject of revivals is well stated by Strickland: "Rankin manifested an opposition to the spirit of revivals, asserting that they tended to disgrace religion by the destruction of order. In this he was promptly met by Asbury, who, although he conceded that some enthusiasm and extravagance might occasionally exist in time of revival, yet deemed it injudicious to animadvert with severity on those exhibitions of passionate excitement which more or less accompanied deep and lasting revivals of religion." 1

While Rankin remained in New York, Shadford had spent a month in New Jersey, adding thirty-five to the societies.

1 "Life and Times of Francis Asbury," p. 100. 


\section{CHAPTER VI.}

\section{EARLY AMERICAN CONFERENCES.}

ON the IIth of July, I773, Asbury left New York for Philadelphia, Rankin meanwhile having called together the preachers for conference. Philadelphia, which was destined to become famous as the seat of the first Continental Congress, now had a privilege which even those inclined to despise the day of small things considered an honorthat of entertaining the first American Methodist conference.

Asbury's and Rankin's journals settle the date as July I 4 th ; yet, as Dr. Stevens remarks, it is surprising how many errors regarding this important event have appeared in subsequent records. Bangs in his history gives July $4^{\text {th }}$, and that was Sunday. The "Life of William Watters," the first American itinerant, assigns the date to June, without day, and Wakeley's "Lost Chapters" to July I6th.

Asbury did not appear at the conference till the second day. His arrival increased the number present to ten, which was the number in attendance upon Wesley's first conference in England, twenty-nine years before. Those present were all Europeans. ${ }^{1}$

This being the first of the conferences of which hundreds

1 Thomas Rankin, Francis Asbury, Richard Boardman, Joseph Pilmoor, Richard Wright, George Shadford, Captain Thomas Webb, John King, Abraham Whitworth, and Joseph Yearbry. 
are now held every year, the minutes constitute a document essential to those who would trace the evolution of American Methodism as an ecclesiastical organization.

"Minutes of Some Conversations between the Preachers in Connection with the Rev. Mr. John Wesley, Philadelphia, June, I773.

"The following queries were proposed to every preacher:

"I. Ought not the authority of Mr. Wesley and that Conference to extend to the preachers and people in America as well as in Great Britain and Ireland?

"Ans. Yes.

" 2. Ought not the doctrine and discipline of the Methodists, as contained in the minutes, to be the sole rule of our conduct, who labor in the connection with Mr. Wesley in America?

"Ans. Yes.

" 3. If so, does it not follow that if any preachers deviate from the Minutes we can have no fellowship with them till they change their conduct?

"Ans. Yes.

"The following rules were agreed to by all the preachers present:

"I. Every preacher who acts in connection with $\mathrm{Mr}$. Wesley and the brethren who labor in America is strictly to avoid administering the ordinances of baptism and the Lord's Supper.

" 2. All the people among whom we labor to be earnestly exhorted to attend the Church and receive the ordinances there; but in a particular manner to press the people in Maryland and Virginia to the observance of this minute.

" 3. No person or persons to be admitted into our love- 
feasts oftener than twice or thrice unless they become members; and none to be admitted to the society meetings more than thrice.

"4. None of the preachers in America to reprint any of Mr. Wesley's books without his authority (when it can be gotten) and the consent of their brethren.

" 5. Robert Williams to sell the books he has already printed, but to print no more unless under the above restrictions.

" 6. Every preacher who acts as an assistant to send an account of the work once in six months to the General Assistant.

"Question I. How are the preachers stationed?

"New York, Thomas Rankin, to change in four months.

"Philadelphia, George Shadford, to change in four months.

"New Jersey, John King, William Watters. ${ }^{1}$

"Baltimore, Francis Asbury, Robert Strawbridge," Abraham Whitworth, Joseph Yearbry.

"Norfolk, Richard Wright.

"Petersburg, Robert Williams. ${ }^{1}$

"Ques. 2. What numbers are there in the Society?

"New York................ 180

"Philadelphia .............. I 80

" New Jersey ............... 200

"Maryland ............... 500

"Virginia................. 100

I 160

"Preachers ............... Io"

At that time the Methodists in America regarded themselves as much under the direction of Wesley as did those

1 Not present. 
in Europe, relying upon him to send them preachers, and such directions as he might deem necessary. The preachers whom he sent agreed to submit to his authority, to adhere to his doctrine, and to establish the same discipline by which the Society in England was governed. The best defense of this attitude, unanswerable from every point of view, is in Lee's " History of the Methodists" (p. 47):

"We were only a religious society, and not a church; and any member of any church, who would conform to our rules and meet in a class, had liberty to continue in their own church. But as most of our society had been brought up in the Church of England (so called), and especially those of Maryland and Virginia, it was recommended to them to attend on the service of that church, and to partake of the ordinances at the hands of the ministers; for at that time the church people were established by law in Maryland and Virginia, and the ministers were supported by a tax on the people. In many places for a hundred miles together there was no one to baptize a child except a minister of the Established Church."

The rule relating to Robert Williams may be considered "the initial step in the establishment of one of the great institutions of Methodism." 1 Lee states that Williams had reprinted, in small pamphlets, many of Wesley's books and sermons, and had circulated them to the great advantage of the movement, distributing them in advance, so that preachers were invited by those who had read them to preach where they had never been heard. Lee further states: "It now became necessary for all the preachers to be united in the same cause of printing and selling our books, so that the profits arising therefrom might be divided among them or applied to some charitable purpose." This harmonized with the method on the other side of the

1 The Methodist Book Concern. 
Atlantic, where Wesley had the exclusive control of publications in the interest of Methodism, appropriating the income thereof to its support and extension.

Those who suppose that in early Methodism human nature was extinguished by divine grace, to be undeceived need only to read "Asbury's Journal," which records that in this conference there were debates "relative to the conduct of some who had manifested a desire to abide in the cities and live like gentlemen, and that when three years out of four had been already spent in the city. Money had been wasted, improper leaders appointed, many of our rules broken."

The number of members above given includes only those who were classified. The preachers had been unable to apply Wesley's method on account of the resistance of the laymen, and some preachers sympathized with them. Almost all that had been accomplished was the result of the strenuous efforts and persuasion of Asbury. Rankin reported to Wesley that nowhere was the discipline properly attended to, except in Philadelphia and New York, and even there it was declining.

Rankin remained a few days in Philadelphia, having the assistance of Pilmoor, and then proceeded to New York, where he was aided at different times by Pilmoor and Boardman. Being General Assistant, and having the care of all the societies in America, while nominally stationed in New York, he was frequently away, always, however, securing the superintendence of the work in his absence. His diary shows that he met with extraordinary success and constantly communed with God. George Shadford was equally zealous and marvelously effective in preaching, and formed a most tender affection for Asbury, compared by a writer in the "Methodist Magazine" for 1816 to the love of David and Jonathan. At the end of 
his first year in America, Shadford had added about two hundred to the society.

Asbury continued the work in the same spirit of selfdenial and incessant labor which had characterized him from the time he arrived in the country. In Baltimore he became intimate with the Rev. Mr. Otterbein and the Rev. Mr. Swoop, pastor of the Lutheran Church; to these he expounded the plan of Methodism, and they decided to imitate Methodist methods as closely as possible.

Wright toiled faithfully in Virginia, and Williams wrought untiringly in that colony and North Carolina. Jarratt, the clergyman of the Church of England, continued to fraternize with Methodists, and was in a sense an American Fletcher, acting upon Methodist principles and imbued with its spirit, without relinquishing his parish. Among the converts made by these preachers were some who attained genuine distinction by usefulness and gained renown by eloquence.

When Asbury, returning from the conference to Baltimore, met Strawbridge, he explained to him the new and peculiar rule concerning the administration of the sacraments, and its special application to Maryland and Virginia. But Strawbridge, who had previously contended for the right of the people to the sacraments, and had administered them before Boardman or Pilmoor, Asbury or Rankin, had arrived in the country, would not comply; and Asbury always stated that the rule was adopted with the understanding that " no brother in our connection shall be permitted to administer the ordinances at this time except Mr. Strawbridge, and he under the particular direction of the assistant." He hoped that Strawbridge, at the first Quarterly Conference, would recognize the effort he had made to conciliate him, and submit to the rule as specially modified in his favor; but "he appeared to be inflexible, 


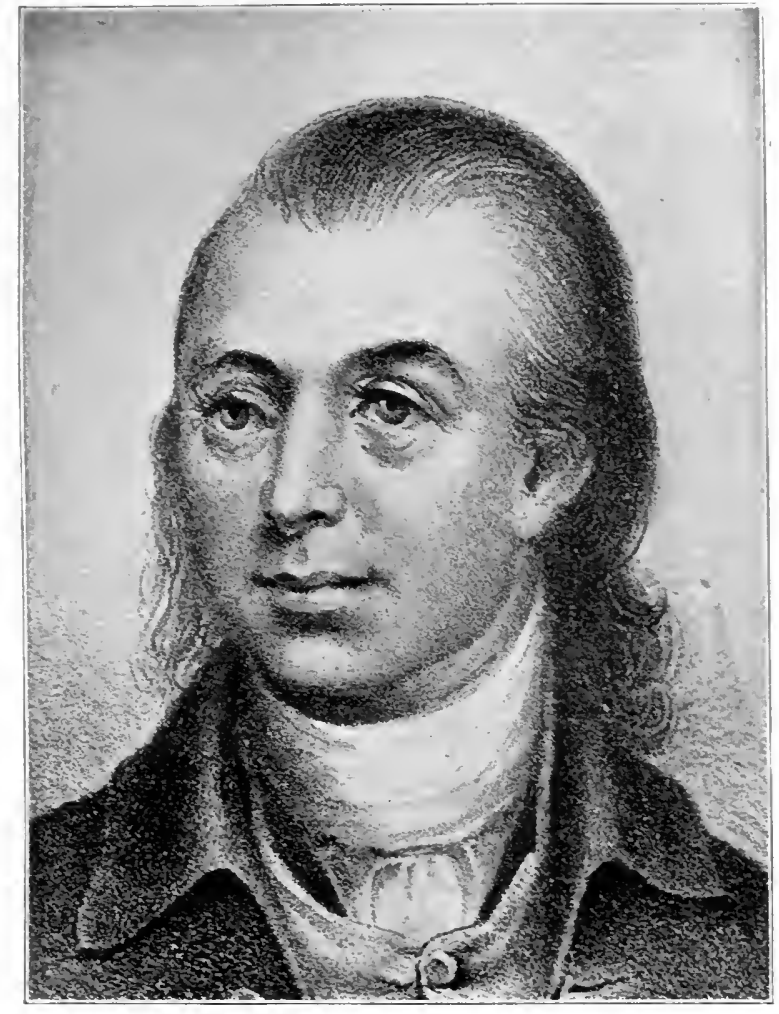

ROBERT STRAWBRIDGE. 

and would not administer the ordinances under our direction at all. ${ }^{1}$ Many things were said on the subject, and a few of the people took part with him."

Dissatisfaction was plainly and even warmly expressed. Asbury, obliged to exert his influence against the uncompromising spirit and rigid methods of Rankin, and the independent and insubordinate spirit of Strawbridge and those who sympathized with him, was adversely criticised by both extremes, until he was compelled to write, "My hand appeared still to be against every man."

Awakenings, conversions, numberless individual inquiries concerning the new way everywhere spoken against, resulting in widespread revivals and the opening of " effectual doors," rewarded the efforts of the small but devoted band that flung their banners to the breeze and turned not back during the rest of the year 1773 and the ensuing spring.

The second Annual Conference was held in Philadelphia, May 25, 1774. At the first but one question was asked concerning the ministers: "How are the preachers stationed?" and one concerning the members in the Society. At the second conference six were asked: "1. Who are admitted this year? 2. Who are admitted on trial? 3. Who are assistants this year?" The fourth is important: "Are there any objections to any of the preachers?" The record is, "They were examined one by one." According to these minutes, two that were stationed in 1773 are to be regarded as having been on trial-Joseph Yearbry and Abraham Whitworth. Under the first question appear two names new to the record, Philip Gatch and Philip Ebert, and the seven admitted on trial are also new. All not classified as "assistants" were known as "helpers." The trhole number of preachers stationed was $I 7$, and the 1 "Asbury's Journal," vol. i., p. 83. 
number of members, 2073. Asbury was stationed in New York and Rankin in Philadelphia, to change in three inonths, and all preachers at the end of six months. The only business recorded related to the salaries of preachers, which were fixed at six pounds per quarter and their traveling expenses (Pennsylvania currency, about sixtyfour dollars a year); but each preacher " received into full connection " was to have the use and property of his horse, which any of the circuits might furnish. A general Easter collection was ordered for sinking debts on chapels and relieving the preachers in want; and it was provided that "wherever Thomas Rankin spends his time he is to be assisted by those circuits."

Four new circuits had been formed. While Robert Williams is mentioned among the assistants, the minutes do not assign him a station, nor does the name of Robert Strawbridge appear.

Of this conference Asbury records: "The overbearing spirit of a certain person [Rankin] had excited my fears. My judgment was stubbornly opposed for a while, but at last submitted to; but it is my duty to bear all things with a meek and patient spirit. Our conference was attended with great power, and, all things considered, with great harmony."

Richard Wright, who had come over with Asbury, though efficient at intervals, had been a comparative failure in this country. Possessed of some gifts, he was spoiled by flattery, and then became unpopular because of the pride and self-seeking which were the natural results of such treatment. Asbury was inclined to sympathize with him, and noted in his "Journal," "the unfaithfulness of some who first spoil a man and then condemn him."

The conference agreed to send Wright back to England; but before he went Asbury visited him, and "found 


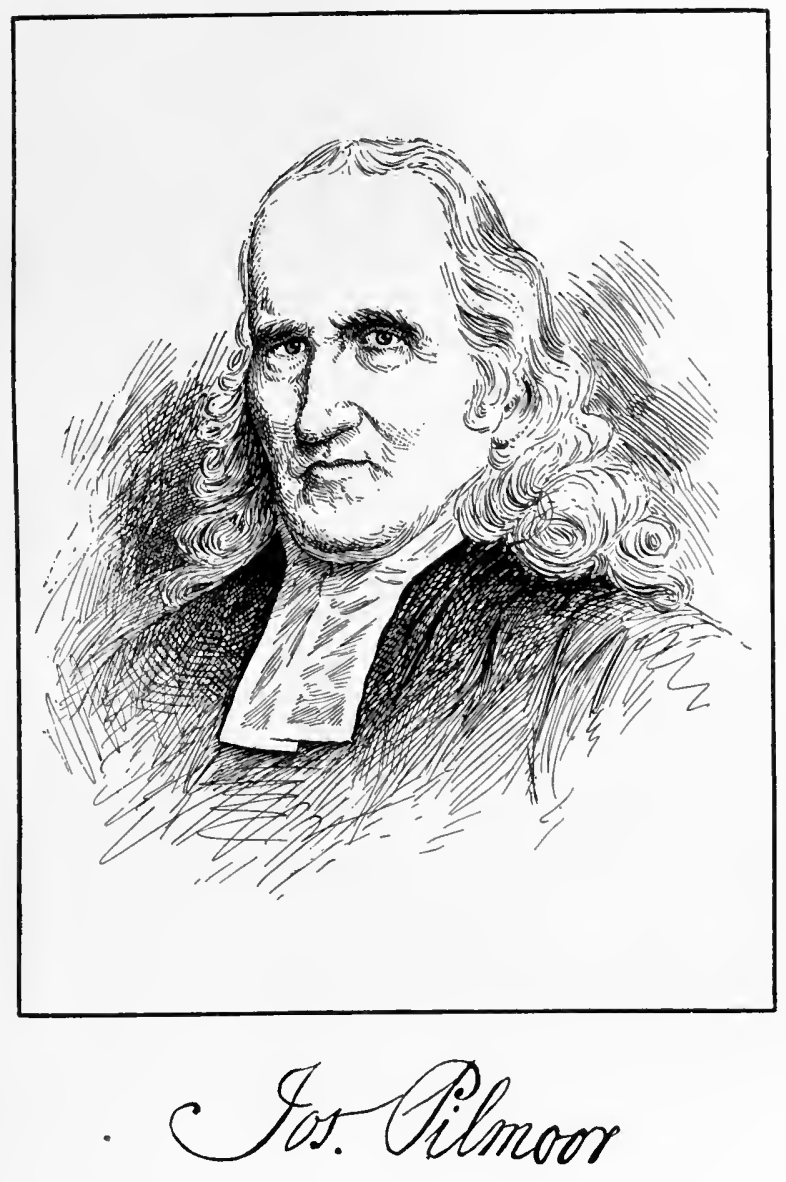



he had no taste for spiritual subjects." Referring to this, he writes, "Lord, keep me from all superfluity of dress, and from preaching empty stuff to please the hearer instead of changing the heart! Thus has he fulfilled as a hireling his day." After his return to England he continued in the service of Wesley but three years, his subsequent career being unknown.

The names of Boardman and Pilmoor had not appeared in the list of those stationed for I 773, though they remained in the country nearly six months, preaching where they had opportunity and assisting at the principal centers. They were, however, Englishmen of the English, and the dark shadows of the coming events of the Revolution excited their apprehensions. On January 2, I 774, " after commending the Americans to God," they sailed for England.

Boardman immediately resumed work in Ireland, and continued therein until I780, when he was appointed to London as an associate of Charles Wesley, Dr. Thomas Coke, and others. The next year he returned to Ireland and traveled upon the Limerick circuit, and in the following was appointed to Cork, where he was highly esteemed, and the people were anxious for his coming. His first sermon was from the text, "Though he slay me, yet will I trust in him." He was unable to preach in the evening; but, though there were symptoms of approaching apoplexy, his physician neglected the case, and about nine o'clock the same day he died. Wesley, speaking of his sudden death, says, "It seems he might have been eminently useful ; but good is the will of the Lord."

Pilmoor desisted from traveling in 1774 . In 1776 he was appointed to London, and afterward, in succession, to the Norwich circuit, Edinburgh, Dublin, Nottingham, Edinburgh again, and York. In 1785 his name disap- 
peared from the English minutes. He returned to America later, took orders in the Protestant Episcopal Church, and was settled in Philadelphia. In $\mathrm{I} 8 \mathrm{O} 2$ there was a division in the parish of Trinity Church, New York, one hundred and twenty-two desiring him as assistant minister. Their petition being disregarded, they seceded and organized a church on Ann Street, over which he was settled. Subsequently he removed to Philadelphia, and was rector of St. Paul's Church. He possessed superior abilities, and Methodistic fervor characterized him until death. The University of Pennsylvania conferred upon him the degree of Doctor in Divinity.

William Watters, born in Baltimore County, Maryland, the son of strict members of the English church, was the first native itinerant preacher. He often heard Strawbridge, King, and Williams; was strongly impressed, lost interest in youthful amusements and society, passed days in great distress of mind; but in May, I77 I, in the house where he was born, his sorrow fled, his prayers were turned into praise, and his experience was epitomized by himself in these words: "I could now, for the first time, call Jesus Christ Lord by the Holy Ghost given unto me." The reading of Wesley's sermons, in one of the pamphlets published by Williams, deepened his convictions. $\mathrm{He}$ adopted and definitely preached the doctrine of Christian perfection, popularly known as "entire sanctification," taught by Wesley, and professed the corresponding experience. Those who knew him best were most impressed with his sincerity, and he was the instrument of the conversion of two of his brothers, both of whom became preachers. Though not present at the first conference, he was among those stationed by it.

Philip Gatch, the second native Methodist preacher reported in the minutes, was a strong character, prone to 
reflect upon religious questions, familiar with the writings of different sects and of the Established Church, in which he was born. Perigeau, a preacher raised up by Robert Strawbridge, preached the first Methodist sermon he ever heard, and "left a want in the heart of Gatch that for six weeks filled him with misery which other preachers did not alleviate." But on the 26th of April, I772, he was emancipated from the spirit of condemnation. His father had threatened to drive him from home, and his elder brother sympathized with the proscription, but was converted, as were the parents, most of the other children, and several collateral members of the family. Gatch was a most valuable addition, and the head of a family still conspicuous in the United States. Such was his ability that John McLean, justice of the Supreme Court of the United States, who knew him well, thought himself well employed in writing his life.

Both Strawbridge and Williams appear to have located. Lindsay, one of those received on trial, was an Irishman, who remained in this country only three years. Dromgoole was likewise an Irishman, who had publicly renounced popery in 1770 , in his native country.

The chief characteristic of the year 1774 was the marvelous success of Asbury in gathering into the societies important families, from whose position and wealth Methodism, in the vicinity of Baltimore, gained material advantages, the value of which was enhanced by their spirituality and strict adherence to Methodist doctrine and discipline. The most conspicuous of these was Henry Dorsey Gough, who was in the enjoyment of a fortune of more than three hundred thousand dollars. His wife was a daughter of Governor Ridgeley, and his country residence, known as Perry Hall, about twelve miles from Baltimore, was "one of the most conspicuous and elegant in Amer- 
ica." His wife was deeply stirred by Methodist preaching, but he denounced it as superstition and forbade her to hear it again; but he was disquieted, and sought relief in wine and gay and irreligious companions. It was proposed that for sport they should hear Asbury. But he possessed a power to solemnize an assembly surpassed only by Wesley, and as they were departing, one of his friends said to Gough, "What nonsense!" "No," replied he, " it is the truth; the truth as it is in Jesus." Entering his house, he said to his wife, "I will never again hinder you from hearing the Methodists." His seriousness increased until he was upon the verge of suicide. Visiting one of his plantations, he heard the voice of prayer and praise in a cabin, and found that a slave from a neighboring plantation was engaged in prayer with his own negroes, "and offering fervent thanksgivings for the blessings of their depressed lot." He was moved to the depths, and cried out: "Alas, $O$ Lord, I have my thousands and tens of thousands, and yet, ungrateful wretch that I am, I never thanked thee as this poor slave does, who has scarcely clothes to put on or food to satisfy his hunger." A few days later he left the dinner-table and went to his room, determined to find peace if possible. Receiving the assurance of forgiveness, he returned to his family and guests, exclaiming, "I have found the Methodists' blessing! I have found the Methodists' God!"

As his establishment comprised one hundred persons, he erected a chapel near his residence. It was the first American Methodist church possessing a bell, and every morning and evening his household and slaves were summoned to family worship. Twice a month the circuit preachers visited it, and local preachers every Sunday.

During this year Abraham Whitworth, the first conspicuous apostate among American Methodists, fell into in- 
temperance and other vices. He had been sent to Kent circuit, and after his lapse Gatch was directed to take his place. His triumphs there were extraordinary; though persecuted, often with violence, every event seemed to contribute to his success. Men who became preachers of unusual ability were converted under his appeals. Kain, a clergyman of the Church of England, and one of his chief opponents, was in the habit of encountering Methodist preachers, demanding their authority, and arrogantly catechising them concerning their qualifications. When he accosted Gatch, the latter informed him that he was about to preach and he could judge for himself. Gatch knew much of the Prayer-book by heart and quoted it frequently to confirm his position; Kain was embarrassed, but at the close, under great excitement, endeavored to read the interview with Nicodemus to prove that baptism by water was necessary and not the new birth. He condemned extempore prayer, and denounced Gatch for not using a written form. The latter rose and gave his experience, declaring that, though he had been baptized in infancy, until the time of his conversion he had never felt the regenerating influence of the Holy Spirit. He adduced various Scripture instances of extempore prayer, and remarked that " when Peter was sinking he did not go ashore to get a prayer-book, but cried out, 'Save, Lord, or I perish!' ",

Portentous complications long existing were about to culminate. Thus far the colonies had had no direct political connection with one another. New Hampshire, New Jersey, Virginia, the two Carolinas, and Georgia were under provincial governments, based on commissions issued to governors appointed by the crown, and limited by the accompanying instructions. Maryland, Pennsylvania, and Delaware were under proprietors, to whom 
had been granted the subordinate powers of legislation and government, and by whom the governor was appointed. Massachusetts, Rhode Island, and Connecticut were chartered governments, the charters being similar, in many respects, to the commissions issued to the provincial governors.

Because of a universal sympathy, community of interest arose between the colonies when Parliament struck a blow at the chartered governments; for, notwithstanding existing dissimilarities, the attempt to alter the charter of Massachusetts alarmed the other colonies, since, if Parliament had that right, none possessed any constitutional guarantees which could not be altered or taken away by its caprice. An act passed in 1774, for the better regulating of the government of the province of Massachusetts Bay, radically changed the executive power, and reconstructed the judiciary in order to subdue the people more completely to the crown. As early as 1754, twenty-five commissioners had assembled from seven States, and a plan of union was adopted, principally the work of Benjamin Franklin. All agreed that an act of Parliament was necessary to authorize it; but it was rejected by every colonial assembly before which it was brought, for they considered that it implied too much of prerogative; and it was rejected in England on the ground that it was too democratic. $^{1}$

The Stamp Act, passed a year before Philip Embury began to preach, led several of the colonies to deny the right of taxation by Parliament, and when, in 1766 , it was repealed, the news caused general satisfaction, which was manifested by fireworks, festivals, and the ringing of bells. But in the act of repeal the government reasserted its right

1 Curtis's " Origin and History of the Constitution of the United States," vol. i., pp. 8-10 (Harper Brothers). 
to tax the colonies, and in 1767 imposed a duty on paper, glass, painters' colors, and teas imported into the colonies. The chief merchants of Boston, Salem, Connecticut, and New York agreed, in I 768, not to purchase or import, during the whole of the next year, any kind of goods or merchandise from Great Britain except a few specified articles. Boston was practically transformed into a garrisoned town because of the large number of British soldiers stationed there to protect the revenue officers in the collection of duties.

The advance mutterings of a distant but swiftly approaching storm were in the air during the whole of 1773 . For two years, when the colonial assemblies met they began business by denouncing the acts of the British ministry; promptly the governors would prorogue them, leaving the people destitute of respect for the government and hostile to the governor personally. But now, before the governors could find an excuse for putting an end to the session, the assemblies constituted " committees of correspondence," to arrange for and maintain concert of action among the colonies. Opposition to taxation had been so effective that in I 772, while the collection of revenue on tea produced about eighty pounds net, it cost more than two hundred thousand to collect it. Then came the scheme by which, although the East India Company was given a drawback of the entire amount of the duty, the people, while yielding the principle and paying the tax, were to get tea at a lower price than any other people, and at less cost than before the duty was imposed. But the colonies would not be bribed. Popular indignation meetings were held in New York and Philadelphia, the captains were ordered to take the tea back, and many of them obeyed. In Charleston, S. C., it was stored in cellars, where it spoiled; in Boston, after long discussion, it was, on December 16 th, thrown 
into the sea. Thus the whole continent, excluding Canada and the French and Spanish possessions, was in a state of excitement.

The arrogance and oppressions of the mother country constantly increased until, less than four weeks after the adjournment of the first American Methodist conference, Benjamin Franklin, then in England as the political agent of Pennsylvania, Massachusetts, and Georgia, wrote an official letter to the Massachusetts Assembly, dated July 7 , I773, recommending the assembling of a general congress of the colonies. That body, styling itself "delegates appointed by the good people of these colonies," convened in Philadelphia, September 5, I774. The Congress did not propose revolution, but regarded itself as the guardian of the rights and liberties of the colonies, and adopted a declaration of rights, in which were summed up the hardships suffered since the year I 763 , and the claim was made of a free and exclusive power of legislation independent of parliamentary jurisdiction in all cases of taxation and internal polity, subject only to the negative of the crown. The declaration also maintained that the colonies were entitled to all the rights, liberties, and immunities of free and natural-born subjects within the realm of England, the right to trial by jury of the vicinage, and to assemble peaceably to consider causes of complaint and to petition the king. They resolved that, after September IO, I 775, they would refuse to export to Great Britain, Ireland, and the West Indies any merchandise or commodity unless their grievances were redressed; and after December I, I 774, they would import nothing into British America from the United Kingdom, or from any other place where the goods, wares, or merchandise had previously been exported from Great Britain or Ireland, and that no such goods, wares, or merchandise should be used. 
Meanwhile the English government steadily pursued the policy of coercion. The petition from Congress to the king was referred to the House of Commons, and by a large majority that body refused to hear it. The trade of England was restricted, the colonists were forbidden to fish on the banks of Newfoundland, and similar embargoes were laid on the Middle and Southern colonies.

The various wars with the Indians and French in which the colonies had been engaged had trained them for battle, and at this time defenses against apprehended hostilities were everywhere being prepared.

The battle of Lexington took place on the I 9 th of April, I 775 ; it was the signal of war, and throughout the country magazines and arsenals were seized by the people. An army of twenty thousand men, volunteers, soon appeared in the vicinity of Boston, and Ethan Allen and Benedict Arnold a little later captured Ticonderoga and Crown Point.

The third Methodist conference, like its predecessors, was held in Philadelphia on the I 7 th of May. At the same time in the same city the second Continental Congress was convened, having organized on the Ioth of May; it continued in session until August Ist, when it adjourned until the $5^{\text {th }}$ of September.

An increase that would have been surprising in any case, but in the distracted condition of the public mind was astonishing, and seemed to the conference a demonstration that God was with them, was noted in the Society, which now had 3148 members, of whom 200 were in New York, 190 in Philadelphia, 300 in New Jersey, and the large remainder, nearly 2500 , south of Philadelphia. Methodism was progressing much more rapidly in Baltimore than elsewhere, there being 840 members in the city and suburbs, and 800 in Brunswick County, Virginia. Nineteen ministers were stationed, among them Robert 
Strawbridge. Contrary to his own judgment, Francis Asbury was appointed to Norfolk, Va. Thomas Rankin, the General Assistant, was instructed to "travel through the connection till the month of September, and then take a quarter in New York." All the preachers in New Jersey were required to change in three months; certain others at the end of six months, and those in Brunswick and Hanover, Va., " as the assistant thinks proper."

The conference ordered throughout the connection a general fast, for the prosperity of the work and for the peace of America, to be observed on Tuesday, the I8th of July.

While the second Continental Congress was sitting, Howe, Burgoyne, and Clinton, with a large force of British troops, arrived on the continent, and on the $I 7$ th of June was fought the battle of Bunker Hill. Immediately after this event an application was made to Congress by the Provincial Assembly of Massachusetts, desiring direction and aid. They informed the Congress that they had raised a force of 13,600 men, and had made proposals to other New England colonies to furnish men in the same proportions; and ventured to suggest that, as they had been compelled to do this, an American army should forthwith be raised for the common cause. The city and county of New York also asked the advice of Congress concerning the course to take with regard to British troops expected in that quarter. Whereupon the Congress at once resolved itself into a committee of the whole to consider the state of America.

It took measures to adopt the regiments that had been raised by the New England provinces as the nucleus of a general army, and added thereto other forces raised for defense, and thus formed the body known to history as the American Continental Army. On the I 5 th of June George 
Washington was unanimously chosen commander-in-chief of these forces.

The centers of the Methodist movement were iNew York, Philadelphia, Baltimore, seaports on Chesapeake Bay, and Norfolk, together with the interior of Virginia, New Jersey, and portions of Pennsylvania and Delaware not remote from the sea-coast. In this condition of actual war, the intense dislike to England, the foreign relations of Methodism, and the fact that the most influential traveling preachers were Englishmen and that the connection acknowledged the authority of John Wesley, exposed them and the societies to a prejudice speedily transformed into hostility whenever they faithfully preached against the immorality which ever accompanies war, and when, as most believed it to be their duty to do, they condemned the prevalence of the warspirit.

No Methodist preacher, especially no European, arose in America during the whole of the year I 775 without immediately dividing the congregation, large or small, into the sympathetic and the suspicious; and the opposition which Methodist preaching on purely moral or doctrinal grounds had everywhere excited was liable at any moment to be transformed into partisan fury or patriotic indignation, according to the temperament of those who perceived, or thought they perceived, any expressed or implied question of the rightfulness of the attitude of the colonies. 


\section{CHAPTER VII.}

\section{IN THE THROES OF REVOLUTION.}

AT the most critical juncture in the political and religious situation of the New World, a still more serious complication was caused by the hostility of John Wesley to the measures taken by the colonists in their struggle against the exactions and impositions of the British government. This was the more offensive to the people of America because, while the struggle was confined wholly to the realm of discussion and diplomacy, he had appeared to sympathize with them rather than with the ministers of the crown and the acts of Parliament.

In the year 1768 he wrote "Free Thoughts on the Present State of Public Affairs," in which he discussed local and current questions. Speaking of the colonies, he said: "I do not defend the measures which have been taken with regard to America; I doubt whether any man can defend them either on the foot of law, equity, or prudence."

To the astonishment of all, the opposition of a large number, and the gratification of every Tory on both sides of the Atlantic, there was issued in 1775 "A Calm Address to our American Colonies, by the Rev. Mr. John Wesley, M.A." The doctrine of this "Address" was that the Americans were the descendants of men who either had no votes or had resigned them by emigration; they therefore possessed exactly what their ancestors left them-not a vote in making laws and choosing legislators, but the happiness of being protected by laws and the duty of 
obeying them. Wesley undertook to show that the late acts of Parliament were the occasion, but not a just cause of the outbreak, and said: "Forty years ago, when my brother was in Boston, it was the general language there, "We must shake off the yoke; we shall never be a free people till we shake off the English yoke." "

Dr. Samuel Johnson had issued, just before this publication, a pamphlet entitled "Taxation no Tyranny," an answer to the resolutions and address of the American colonies. Wesley's "Calm Address" was little more than an abridgment of this essay; and, as he made no reference to Dr. Johnson, he was "at once pounced upon as a plagiarist and a renegade of the worst description." "Wesley was now one of the most conspicuous men in England, and perhaps no ecclesiastical personage of the realm swayed a wider influence over the masses on questions involving religious interests. Hence the publication of his 'Calm Address' produced an unparalleled sensation." 1

The controversy waxed bitter, and the titles of the pamphlets, the details, and the replies, though intended to be sarcastic and cutting, seem trivial, when they are not mere vulgar abuse, at the present day. One was "A Cool Reply to "A Calm Address" "; another, "A Wolf in Sheep's Clothing ; or, An Old Jesuit Unmasked "; and the youthful Toplady, Wesley's most virulent foe, author of " Rock of Ages," seized his opportunity and wrote a tract entitled "An Old Fox Tarred and Feathered." In this he charged that Wesley's "Calm Address," as to both matter and expression, was " a bundle of Lilliputian shafts picked and stolen out of Dr. Johnson's pincushion." 2

1 Tyerman's "The Life and Times of John Wesley," vol. iii., pp. 186, 187.

2 For full discussion of the subject and references to other pamphlets, see Tyerman's "The Life and Times of John Wesley," vol. iji. 
Meanwhile Dr. Johnson wrote to Wesley, thanking him for the addition of "your important suffrage to my argument on the American question. To have gained such a man as yourself may justly confirm me in my own opinion. What effect my paper has upon the public I know not; but I have no reason to be discouraged. The lecturer was surely in the right who, though he saw his audience slinking away, refused to quit the chair while Plato stayed." 1

The first in the field and the ablest of Wesley's critics was Caleb Evans, a Baptist minister, and, by the testimony of one who had no sympathy with the American cause, " a man of good sense, a diligent student, a faithful pastor, and extensively useful, but a rampant advocate of what was called liberty." In a pamphlet he charged Wesley with having suddenly changed his opinions; with having at the late election advised the Bristol Methodists to vote for the American candidate; and further, with having but a short time before recommended a book entitled "An Argument in Defense of the Exclusive Right Claimed by the Colonies to Tax Themselves."

Wesley denied that he had seen the book; but Evans proved that William Pine, Wesley's own printer, and the Rev. James Roquet, his friend, were both prepared to attest on oath that Wesley had recommended that book to them. Evans was by this testimony convinced that Wesley had deliberately falsified, and in a new edition of his tract directed attention to "the shameful versatility and disingenuity of this artful man."

Thomas Olivers, one of Wesley's converts, came forward early in 1776 with "A Defense of the Rev. John Wesley" on the ground of pressure of business and advancing years, on account of which he had forgotten that he had recommended the book or even seen it. Olivers said that he 
preached and exhorted twenty or thirty times a week and often more, answered thirty or forty letters, prepared something in whole or in part for the press, and a large variety of tracts on different subjects passed through his hands; it was not, therefore, strange that his memory should often fail. But Wesley's native frankness was his best vindicator; for on the I 2 th of November, I 775, he had written to the Rev. Mr. Roquet this letter:

"DEAR JAMES: I will now simply tell you the thing as it is. As I was returning from the Leeds Conference, one gave me the tract which you refer to, part of which I read on my journey. The spirit of it I observed to be admirably good, and I then thought the arguments conclusive. In consequence of which, I suppose (though I do not remember it), I recommended it both to you and others; but I had so entirely forgotten it that even when it was brought to me the other day I could not recollect that I had seen it.

$$
\begin{aligned}
& \text { "I am, etc., } \\
& \text { "JohN WesLey." }
\end{aligned}
$$

Several Methodist writers honestly and benevolently attempt to relieve the memory of John Wesley from the charge of hostility to the cause of the colonists during the Revolutionary struggle. But we are reluctantly compelled to demonstrate that the method which they adopt is without historical support, and capable of absolute disproof.

This is the case as presented by Stevens:

"Wesley's error in this publication [the "Calm Address"] afforded him a signal advantage at last-the opportunity in the same year of frankly correcting himself, and of acknowledging the right of the colonies in their stern quarrel. . . . 
"The day of Lexington and Concord struck Europe with surprise, and gave a new and stern argument on the question to thoughtful Englishmen. Wesley saw its significance at once. Waiting but one day after the arrival of the news, he wrote to Lord North and the Earl of Dartmouth, severally, an emphatic letter.

"'I am,' he said, 'a High-churchman, the son of a High-churchman, bred up from my childhood in the highest notions of passive obedience and non-resistance; and yet, in spite of my long-rooted prejudices, I cannot avoid thinking these, an oppressed people, asked for nothing more than their legal rights, and that in the most modest and inoffensive manner that the nature of the thing would allow. But waiving this, I ask, Is it common sense to use force toward the Americans? Whatever has been affirmed, these men will not be frightened, and they will not be conquered easily. Some of our valiant officers say that "two thousand men will clear America of these rebels." No, nor twenty thousand, be they rebels or not, nor perhaps treble that number. They are strong; they are valiant; they are one and all enthusiasts, enthusiasts for liberty, calm, deliberate enthusiasts. In a short time they will understand discipline as well as their assailants. But you are informed "they are divided among themselves." So was poor Rehoboam informed concerning the ten tribes; so was Philip informed concerning the people of the Netherlands. No; they are terribly united; they think they are contending for their wives, children, and liberty. Their supplies are at hand, ours are three thousand miles off. Are we able to conquer the Americans suppose they are left to themselves? We are not sure of this, nor are we sure that all our neighbors will stand stock-still." " 1

1 Stevens's "History of the Methodist Episcopal Church," vol. 1., pp. 283 , $28_{4}$. 
The assumption upon which this theory rests is that Wesley had written the "Calm Address" before the battle of Lexington, and that the intelligence of it caused him to change his opinions and write these letters to Lord North and the Earl of Dartmouth; whereas he wrote the letter to Lord North while he still sympathized with the colonies, and was aftercuard convinced by Dr. Johnson's pamphlet that their cause was not well founded. ${ }^{1}$ Yet the exhibition of this letter to George Bancroft, who had properly represented Mr. Wesley's state of mind upon this subject, led that historian to modify his views, which Stevens thus recognizes:

"I am happy to acknowledge, in behalf of the Methodist community, their obligations to Mr. Bancroft, who, when this important document was brought under his notice, had the candor to qualify by it his former allusions to Wesley, though in order to do so it was necessary to cancel one or more of his stereotype plates. He inserts a large extract from the letter in the sixth edition of his seventh volume. The Methodist denomination will congratulate itself that its venerated founder is thus, almost for the first time in civil history, fairly represented in respect to this question, and that this justice has been accorded in a work which, by its remarkable merits, will be as immortal as its theme." ${ }^{2}$

The solemn predictions of that portion of Wesley's letter to Lord North quoted by Stevens were fulfilled, and there is much in the remainder which exhibits extraordinary foresight.

Until a short time after the Leeds Conference, August I, I 775, he was of the same way of thinking; but in a few

1 Wesley's famous letter to Lord North was written at Armagh, June 15, 1775 .

"History of the Methodist Episcopal Church," vol. i., p. 284. 
[Chap. vil.

weeks Dr. Johnson published "Taxation no Tyranny," which caused him to reverse the direction of his impulsive current, and he at once threw out this firebrand.

To determine beyond future question the cause, the date, and the consequences of his change, the following indisputable testimony is adduced.

Wesley published in the autumn of 1775 a second edition of the "Calm Address." Concerning this he writes to his brother Charles:

"October 19, 1775.

"It takes time to set people's heads right; but we must despair of nothing. I have cast my bread upon the waters, and should have been content though there had been no present fruit. Some hours this morning I devote to 'Americanus.' What is material I shall endeavor to answer. It is well if I can give as good account of everything else as of my change of judgment. I find a danger now of a new kind-a danger of losing my love for the Americans; I mean, for their miserable leaders. . . ."1

And again :

“London, October 28, 1775.

"I am just putting into the press a new edition of the 'Address,' corrected, in which my change is acconnted for and two of the questions fully answered." ${ }_{2}$

The new edition contained "A Preliminary Address to the Reader," in which Wesley says:

"I was of a different judgment on this head till I read a tract entitled 'Taxation no Tyranny.' But as soon as I received more light myself $I$ judged it to be my duty to impart it to others. I therefore extracted the chief arguments from that treatise, and added an application to those

I Wesley's "Works," vol. vi., p. $676 . \quad 2$ Ibid., vol. vi., p. 677. 
whom it most concerns. I was well aware of the treatment this would bring upon myself; but let it be, so I may in any degree serve my king and country." This settles the case that, instead of changing from the support of the government to advocacy of the colonies, he changed from sympathy with the colonies to advocacy of the government.

Late in the same year Wesley addressed this letter to "Lloyd's Evening Post":

"SIR: I have been seriously asked, From what motive did you publish your 'Calm Address to the American Colonies'?

"I seriously answer, Not to get money. Had that been my motive, I should have swelled it into a shilling pamphlet and have entered it at Stationers' Hall.

"Not to get preferment for myself or my brother's children. I am a little too old to gape after it myself; and if my brother or I sought it for them, we have only to show them to the world.

"Not to please any man living, high or low. I know mankind too well. I know they that love you for political service love you less than their dinner; and they that hate you hate you worse than the devil.

"Least of all did I write with a view to inflame any; just the contrary. I contributed my mite toward putting out the flame which rages all over the land. This I have more opportunity of observing than any other man in England. I see with pain to what a height this already rises in every part of the nation. And I see many pouring oil into the flame by crying out, 'How unjustly, how cruelly, the king is using the poor Americans, who are only contending for their liberty and for their legal privileges!'

"Now there is no possible way to put out this flame, or hinder its rising higher and higher, but to show that the 
Americans are not used either cruelly or unjustly; that they are not injured at all, seeing they are not contending for liberty - this they had even in its full extent, both civil and religious; neither for any legal privileges, for they enjoy all that their charters grant. But what they contend for is the illegal privilege of being exempt from parliamentary taxation-a privilege this which no charter ever gave to any American colony yet; which no charter can give, unless it be confirmed both by king, lords, and commons; which, in fact, our colonies never had; which they never claimed till the present reign; and probably they would not have claimed it now had they not been incited thereto by letters from England. . . .

"This being the real state of the question, without any coloring or aggravation, what impartial man can either blame the king or commend the Americans?

"With this view-to quench the fire by laying the blame where it was due-the 'Calm Address' was written. ...

"John Wesley."

Under date of December 9, I 776, his "Journal " contains this entry: "In answer to a very angry letter, lately published in 'The Gazetteer,' I published the following: ${ }^{1}$

" To the Rev. Mr. Caleb Evans.

" "REv. SIR: You affirm (I) that I once "doubted whether the measures taken with respect to America could be defended either on the foot of law, equity, or prudence." I did doubt of these five years, nay, indeed, five months ago. "You affirm (2) that I "declared" (last year) "the Americans were an oppressed, injured people." I do not remember that I did; but very possibly I might.

1 Wesley's "Works," vol. iv., p. 445. 
" "You affirm (3) that I then "strongly recommended an argument for the exclusive right of the colonies to tax themselves." I believe I did; but I am now of another mind. . . .

$$
\begin{aligned}
& \text { "Your humble servant, } \\
& \text { "“John Wesley." }
\end{aligned}
$$

In the same year he published a long pamphlet entitled "Some Observations on Liberty," in which he compared John Hancock to a felon, contended against every proposition by which the colonists supported their cause, and called upon them to lay down their arms. The American editor of John Wesley's works, the celebrated and accomplished John Emory, is compelled to insert as a foot-note to this tract, "As a political publication it cannot fail to meet the strong and decided disapprobation of Americans; and we insert it here, with a few others alike foreign to our own views, solely to fulfill our promise of a complete edition of his works." 1

It is an error to suppose that this change reflects in any degree adversely upon John Wesley. He was absolutely honest, but his training and mode of thought made it impossible for him to sympathize with the colonists from. the moment they determined upon revolution, and his horror of war intensified his feelings.

It is necessary to elucidate this subject that the distrust felt toward the Methodists may be explained, and the honor due Asbury and those who stood with him may be intelligently conferred.

Asbury regarded the change with discriminating charity, for, on receiving a letter from Wesley, he made this comprehensive entry:

"I also received an affectionate letter from Mr. Wesley, 1 Wesley's "Works," American edition, vol. vi., pp. 300-321, 
and am truly sorry that the venerable man ever dipped into the politics of America. My desire is to live in love and peace with all men; to do them no harm, but all the good I can. However, it discovers Mr. Wesley's conscientious attachment to the government under which he lives. Had he been a subject of America, no doubt but he would have been as zealous an advocate of the American cause. But some inconsiderate persons have taken occasion to censure the Methodists in America on account of $\mathrm{Mr}$. Wesley's political sentiments." 1

American Methodism had fully entered upon a period of external persecution and internal difficulty, and the correspondence of Asbury and Rankin had convinced Wesley that they were unable to agree. He wrote to the latter, March I, I 775 :

"Dear Tommy: As soon as possible you must come to a full and clear explanation both with Brother Asbury and with Jemmy Dempster. But I advise Brother Asbury to return to England the first opportunity."

On April 2 Ist of the same year he wrote: "Brother Asbury has sent me a few lines, and I thank him for them. But I do not advise him to go to Antigua. Let him come home without delay." 2

And May I9th: "I doubt not but Brother Asbury and you will part friends; I hope I shall see him at the conference. He is quite an upright man. I apprehend he will go through his work more cheerfully when he is within a little distance from me." 3

This shows that Rankin had prejudiced Wesley against Asbury.

1 "Asbury's Journal," vol. i., pp. I76, 177.

2 Wesley's "Works," vol. vii., p. 8.

3 Ibid., vol. vii., p. 9 . 
Having been informed that Asbury remained in the work, Wesley wrote to Rankin, August I3, I 775: "I am not sorry that Brother Asbury stays with you another year. In that time it will be seen what God will do with North America, and you will easily judge whether our preachers are called to remain any longer therein."

Among the important spiritual results of the year were those which attended the preaching of George Shadford and his colleagues in Virginia. At that time many of the planters were little better than heathen, and the country was given up to dissipation. Shadford's pathetic eloquence moved all classes. The chief dancing-master came to hear him clad in scarlet on the week-days, and on Sunday in green, and was so affected that he relinquished a large and profitable school and began to teach ordinary English branches. When Shadford asked his name, a friend said that he was called Madcap. Shadford responded, "A very proper name for a dancing-master;" but afterward he found this was only a nickname, his real name being Metcalf. This man became one of the most devoted members of the connection, lived for six or seven years a useful life, and "died a great witness for God."

His progress checked by a flood, Shadford applied to a planter for entertainment, and was kindly received. After partaking of refreshment, he inquired if the country were well inhabited, and on being told that it was, proposed to the planter to invite his neighbors that he might preach to them. Shadford's description of the results is concise and quaint: "He sent out and we had many hearers, but they were as wild boars. After I had reproved them they behaved very well during the preaching. When I conversed with the planter and his wife, I found them entirely ignorant of themselves and of God; I labored to convince them both, but it seemed to little purpose." It was not 
long, however, before they were spiritually illuminated. From this circumstance the place became a local appointment, and later a church was erected there. In two or three years it numbered 70 persons, and on the whole circuit in that year 1800 members were added.

The Conference of 1776 was held in Baltimore, and the reports exhibited an increase of 1773 members, the total being $492 \mathrm{r}$. The number of preachers had increased in similar ratio, being at this time 24,9 of whom were admitted on trial.

Among them was Freeborn Garrettson, who, having been long under conviction of sin and a devout attendant at church, began to hear the Methodist preachers, and, after months of mental perturbation, was converted while on horseback. His own words contain one of the clearest delineations in religious biography of final surrender of the soul to God, and that reconstruction of mind and heart which became the basis of the life-work of the Methodists. ${ }^{1}$ Yet the next morning after his conversion he was beset with temptations which he attributes to the devil; but a careful consideration of his early experience shows that those temptations were the results in their intellectual form of the struggle between his new and old views, and the entire change of his relations in life, which he saw to be the logical consequence of his experience. His perturbation increased; for, although plainly called to preach and willing to act as a local supply, he could not consent to become a traveling preacher. At last he was almost weary of life; but after newly consecrating himself to God, and declaring that if God would manifest his will he would submit, he threw himself upon the bed and immediately fell asleep. He then dreamed that the devil appeared before him and at that minute a good angel came and said,

1 Bangs's " Life of Garrettson," p. 36. 

"Will you go and preach the gospel?" He declined on the ground that he was unworthy; whereupon the devil seized him, and he saw that there was but one way of escape, and that a narrow one. The good angei again asked him if he would preach, and he consented. Awaking in a rapture, he resolved to go; yet after he set out he was so tortured that he was " ready to desire that his horse might throw him and put an end to his life, or maim him so that he might not be able to go on." These struggles continued until the Conference of 1776 , when he was duly received on trial and fully established in a career which was like the path of the just-a shining light, increasing more and more unto the perfect day.

Asbury was unable to reach the conference at Baltimore; but on the 27 th of May, when informed by Rankin that he was appointed to Baltimore, he cheerfully submitted, though he feared that the climate would be injurious to him.

In less than three weeks after the conference adjourned, the motion was made in the Continental Congress to declare the colonies free and independent; and on the $4^{\text {th }}$ of July the immortal Declaration of Independence was adopted, after which loyalty to the British crown became a crime. Prayers for the king were forbidden on penalty of imprisonment. No man, at least in the vicinity of active operations, could travel without a passport, and none could be obtained by those who refused to take the test-oaths, which varied in different colonies, some requiring the taking up of arms in favor of national independence if called upon to do so by the authorities.

Early in the summer Asbury had repaired to Baltimore, where he was received by Mr. Gough. In one of his excursions he was arrested for preaching the gospel and fined five pounds. Though his health was very poor, his daily 
work was as follows: "To read about a hundred pages a day; usually to pray in public five times a day and to lecture in prayer-meeting every evening."

The Cherokee Indians had begun to break out, and on the 3 Ist of July his mind was disturbed by the reports of slaughters. English ships were coasting to and fro, watching for some advantages; but " what," asked he, "can they expect to accomplish without an army of two or three hundred thousand men? and even then there would be but little prospect of their success."

Mr. Gough accompanied Asbury to the warm sulphur springs, where the latter remained six weeks. He thought himself, in this visit, still in the way of duty, and after a week's stay wrote: "There is a manifest check to the frightful tide of immorality, and the prejudices of many people are in a great degree removed, so that I hope that my visit to this place will be for the benefit of the souls of some as well as for the benefit of my own body." While there Asbury met members of other denominations, and records: "My spirit has been much united to the faithful people of God of every denomination." The house in which he stayed was not the most agreeable. "The size of it was twenty feet by sixteen, and there were seven beds and sixteen persons therein, and some noisy children." The parson there had encouraged the gentlemen to oppose him. When he departed he says: "I this day turn my back on the springs as the best and the worst place that I ever was ingood for health but most injurious to religion."

He received information on the $2 \mathrm{~d}$ of April, 1777 , that some of his brethren had determined to leave the country, and he wrote to George Shadford that as long as he could stay and preach without injuring his conscience it appeared to be his duty to abide with the flock.

The Conference of 1777 was held May 2oth, at a preach- 


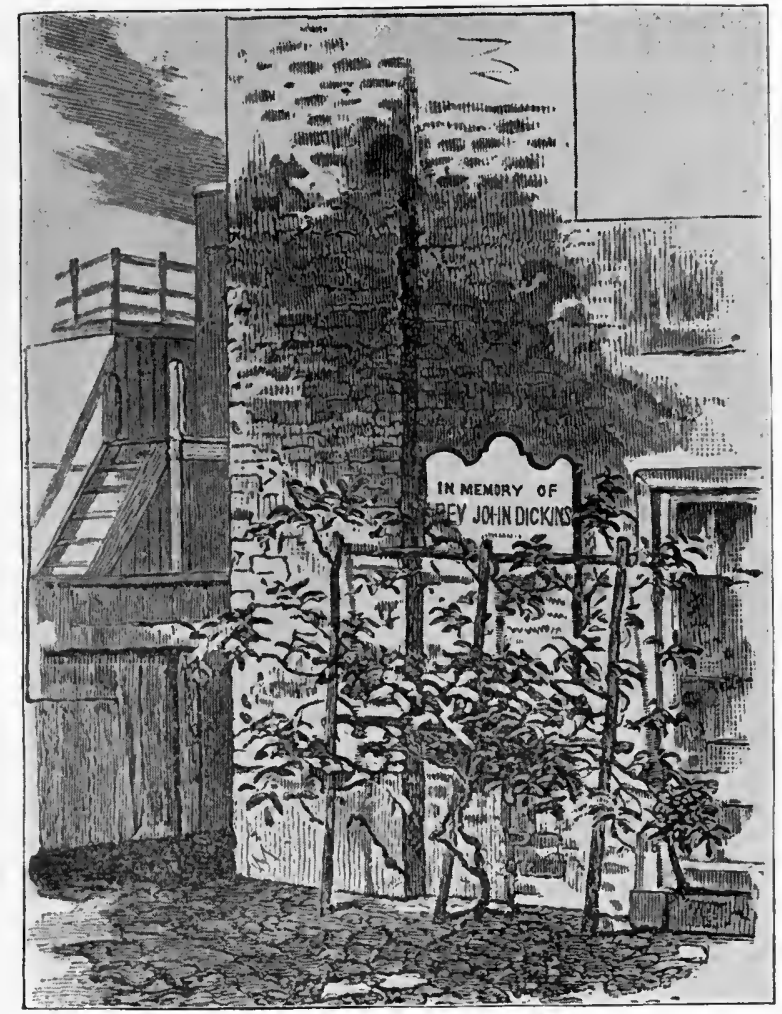

MEMORIAL TABLET OF JOHN DICKINS. 

ing-place near Deer Creek, in Harford County, Maryland, and, notwithstanding the troublous times, there had been an increase of 2047 in the membership, the total being 6968 , and an increase of preachers from 24 to 36 . Fourteen had been admitted on trial, the first of the list being Caleb B. Pedicord, a man of unusual sweetness of spirit and efficiency in conversions and every form of spiritual influence. Another was John Dickins, of high intellectual ability. New York appears in the list of stations, but without a minister, as it was inaccessible by reason of the occupation of the city by the British army. Another fastday was appointed. The preachers resolved not to take any steps to detach themselves from the work of God for the ensuing year, and in view of the fact that the preaching of funeral sermons had been carried so far as to become contemptible, they determined to inform every society that they would not preach any funeral sermons except for those "that we have reason to think died in the fear and favor of God."

Twenty preachers were present at this conference; and the business was conducted with harmony, peace, and love. The brethren who intended to return to Europe agreed to remain until the way was quite open. The conference closed, however, in deepest distress. Asbury remarks that it was such a parting as he never saw before, the American preachers thinking that they should not see the faces of their English fellow-laborers any more; for these men could not take the oaths required, and therefore were liable at any moment to arrest, and thus would be prevented from performing the work of the ministry.

Soon after the conference Asbury was invited by the vestrymen of Garrettson Church to become its pastor; but declined the call, justly regarding himself as providentially occupied. 
On the 2 Ist of July Asbury heard Rankin preach his last sermon in America, and remarks that his own mind was " a little dejected, and he felt some desire to return to England, but was willing to commit his way to the Lord," and should do nothing that would separate him from his brethren, adding: "I hope to live and die a Methodist."

In the autumn of 1775 Robert Williams died, and Asbury preached his funeral sermon, characterizing him in terms which give his name a place of honor in the history of this country and of Christianity: "He has been a very useful, laborious man, and the Lord gave him many seals to his ministry. Perhaps no one in America has been an instrument of awakening so many souls as God has awakened by him." 1

Unable to take the test-oaths or to sympathize with the colonies, Rankin left the country. In an autobiographical narrative ${ }^{2}$ he says: "The British being in possession of Philadelphia, I left Maryland in September, and through divers dangers got safe into that city in the month of November. I spent the winter there, and left the capes of Delaware on the 17 th of March, I 778, and arrived safe at the Cove of Cork on the I 5 th of April."

Martin Rodda, another English preacher, having been so indiscreet as to distribute copies of the king's proclamation, was obliged to escape to the coast by the help of slaves, but reached Philadelphia and took refuge in the British fleet. In October, I 777, Shadford informed Asbury that Rankin and Rodda had left the continent. This, however, must refer to their retiring into the British lines, after which Shadford had no communication with them and supposed that they had departed to England. 
After the departure of Rodda and Rankin, only Shadford of the English preachers remained with Asbury. Early in I 778 Asbury was staying with his friend, Thomas White, who was a devout and consistent member of the English church, a distinguished citizen, and Chief Justice of the Common Pleas. His wife, of the same communion, was of the type of Susanna Wesley, training her family and giving special Bible instruction to her slaves. The first time she heard Methodist preaching she recognized its predominant spiritual quality, and found in its fervency a response to the longings of her own ardent nature. Inducing her husband to accompany her with the children to one of their appointments, he was so favorably affected by what he heard that he invited the preachers to his residence, where services were held regularly till the erection of "White's Chapel."

While here Shadford urged upon Asbury to consider whether it was not their duty to return home. They agreed to spend a day together in fasting and prayer for the settlement of this question; but their impressions at its close were very dissimilar. Said Asbury, "My convictions are as clear and strong as ever that it is my duty to remain." Shadford said, "My work in America is done; I feel with as much certainty that it is my duty to return now as I felt it to be my duty to come hither four years ago." Then said Asbury, "One of us must be in error." "Not necessarily so," was the reply; "I may have a call to go and you to stay." 1

Asbury, referring to the departure of George Shadford and Samuel Spraggs, " says:"I am under some heaviness of mind. But it is no wonder: three thousand miles from home; my friends have left me; I am considered by

1 "Bishop Asbury," by Frederick W. Briggs, M.A. (London, third edition, p. I I9). 
some as an enemy of the country, every day liable to be seized by violence and abused. However, all this is but a trifle to suffer for Christ and the salvation of souls. Lord, stand by me!" 1

Shadford said subsequently: "I believe we both obeyed the call of Providence. We saw we must part, though we loved as David and Jonathan: and, indeed, these times made us love one another in a peculiar manner. Oh, how glad were we to meet and pour our griefs into each other's bosom!" 2

Although provided with a passport, Shadford was attacked on the highway and his life threatened; but he returned in safety to England. There he was very useful, highly honored, and lived to old age, when, though blind, he led a class of one hundred persons. At evening-time it was light, for in his last years he was happily married, and his blindness was cured by a surgical operation. "You will have the pleasure," said the surgeon, "of seeing to use your knife and fork again." "Doctor," replied the veteran, "I shall have a greater pleasure-that of seeing to read my Bible." 3

This good man " excelled any of Wesley's other American missionaries in immediate usefulness." 4

Methodists were now almost universally under the suspicion of being Tories. In Maryland the test-oaths required a pledge to take up arms if called upon to do so by the authorities, and this was against Asbury's conscience as a preacher of the gospel. He therefore retired to Delaware, making his home with Judge White. In March, I778, he wrote: "Blessed be God! his providence hath cast my lot in a quiet, agreeable family, where I can make

1 "Asbury's Journal," vol. i., p. 268.

2 Stevens's "History of the Methodist Episcopal Church," vol. i., p. 340.

3 Ibid., vol. i., p. 342. 
the best improvement of my time in study and devotion. I intend to abide here for a season till the storm is abated. The grace of God is a sufficient support while I bear the reproach of men and am rewarded evil for all the good which I have done and desire to do for mankind. I am strongly persuaded that divine Providence will bring about a change before long." 1

Judge White was arrested on the 2d of April, and Mrs. White, the children, and Asbury were left in great alarm. Regarding himself as to some extent the cause of his host's arrest, Asbury determined to depart as soon as possible. He traveled over a lonesome and crooked road, but late at night found a shelter where he thought he might remain, comforting himself by reflecting that his trials were like those of the saints of olden times who wandered in deserts, in mountains, in dens and caves of the earth, but recognizing the fact that their afflictions far exceeded his. The next day he spent much of his time reading the Bible and the Greek Testament; but a report reached him that it would be better for him to depart. In the morning he started, but had to hide in a swamp till about sunset, when he took refuge with a friend.

While in this neighborhood news came that Joseph Hartley had been arrested in Queen Anne County, Maryland, on the preceding Sunday. This depressed him; but, called on to visit a man in distress of mind, and being successful in leading him to trust in the Lord, he encouraged himself by the thought that Providence might have sent him there for that purpose.

He was hidden among these strangers for a month, when he ventured back to the mansion of Judge White. The latter had been seized on the charge of being a Methodist and presumptively a Tory, but after five weeks' detention

1 "Asbury's Journal," vol. i., p. 269. 
was acquitted. With him Asbury spent many months; but, after a brief period of almost absolute concealment, he began correspondence with Methodists, moved about among the societies near at hand, and sometimes preached.

In the same State, and at no great distance, he gained the friendship of Judge Barrett, and of a far more distinguished man, Richard Bassett, a renowned lawyer of Delaware, a member of the convention which framed the Constitution of the United States, a Senator in the first Congress, and a judge of the United States Court for the district including Pennsylvania, New Jersey, and Delaware. $^{1}$

The governor of Delaware, who was not a Methodist nor even a religious man, came to regard Asbury and the Methodists with such favor that he wrote to the governor of Maryland in behalf of the suffering Methodists in that State, leading to their release from prison. Lednum states that a letter which Asbury wrote to Rankin in 1777 (in which he imparted his belief that the Americans would become a free and independent nation, and declared that he was too much knit in affection to many of them to leave them, and that Methodist preachers had a great work to do under God in this country) had fallen into the hands of the authorities in America, and had produced a decided change in their feelings toward Asbury.

It was while Asbury was concealed at Judge White's that Bassett met him. Being on a professional journey, he called there to spend the night, and as he opened the door caught a glimpse of Asbury and some other preachers, and said to Mrs. White, "Who are those men dressed in sable garments and keeping themselves aside?" She replied, "They are some of the best men in the world; they are Methodist preachers." Bassett, disturbed by this

1 Cooper's "Discourse on the Life of Asbury." 
information, replied, "Then I cannot stay here to-night." Said Mrs. White, "You must stay ; they cannot hurt you."

At the table Bassett was delighted with Asbury's conversation, and invited him to call in case he visited Dover. On his return home he told his wife of this meeting and what he had done; whereat she was greatly troubled, and he could appease her only by saying, "It is not likely that he will come." But a while later, looking out of his window, he saw the Methodist approaching. "That evening Asbury charmed by his conversation a large circle at the tea-table till late into the night."

After Judge White had publicly avowed his connection with the Methodists he visited Judge Bassett. It was reported about the streets of Dover that a Methodist was there, and a crowd, who thought all Methodists Tories, surrounded the house to seize him. Bassett, who was a militia officer, with drawn sword met them at the door and shouted, "He is no more a Tory than you are. You shall have him only by passing over my dead body." 1

The Conference of I 778 was held at Leesburg, Va., May I 9 th, and its records show a decline in members of 873 and in preachers stationed of 7 . Important changes had transpired in all parts of the country where Methodism existed. Six new circuits were added at this conference in Virginia, and the Carolina circuit in North Carolina was divided into three, named respectively Roanoke, Tar River, and New Hope; but on account of the war five of the old circuits were wholly omitted from the minutes; these were New York, Philadelphia, Chester, Frederick, and Norfolk.

Asbury was a firm believer that evil pursues those who obstruct the Word of God. In harmony with this view, under date of May I6, I 778, he entered in his "Journal" 
these words: "It may be observed that two of our preachers have been apprehended rather than do violence to conscience; and the men by whom they were both taken were dangerously wounded within a few weeks after they had laid hands upon them." 1

He often felt his loneliness: "I saw myself pent up in a corner; my body in a manner worn out; my English brethren gone, so that I had no one to consult." He thus prayed: "Lord, must I pine away and quench the light of Israel?" 2

Throughout the year I 778 his "Journal" tells of constant work. The entry for December I 8 th is : "For twenty months before these troublesome times fully came I foresaw the probability of them, and was much stirred up to rely upon God and prepare for the worst." ${ }^{3}$ January 2, I779, he says, "Upon mature reflection, I do not repent my late voluntary retirement in the State of Delaware." 4

A significant entry occurs for April 4, I779: "Lord's day.-I breakfasted with a Presbyterian minister, and endeavored to answer some objections which he started; but could not attempt a vindication of those amongst us who had dipped deep in politics." 5

Two conferences were held this year; the first for the Northern stations, at the house of Judge White, on the 28 th of April. All the preachers were present, and Caleb Pedicord was the only probationer received into full membership at this conference. Several important entries are made, and for the first time appears the question, "Who desist from traveling?" under which are recorded two names. "Who of the preachers are willing to take the stations this conference shall place them in?" Sixteen signatures were appended to this. No helper was to make

1 "Asbury's Journal," vol. i., p. 277.

2 Ibid., vol. i., p. 287 .

3 Ibid., vol. i., p. 296.
4 Ibid., vol. i., p. 298.

5 Ibid., vol. i., p. 308 . 
any alteration in the circuit or appoint preachers to any new place without consulting the assistant. It was stated that the Delaware Conference was held for the convenience of the preachers in the Northern stations, that all might have an opportunity of meeting, and that it was considered as preparatory to the conference in Virginia. They agreed to guard against a separation from the church, directly or indirectly, to meet the children once a fortnight, and to examine parents with regard to their conduct toward their children.

But the questions which were to exert the most farreaching influence over American Methodism were the twelfth and thirteenth. ${ }^{1}$

"Ques. I2. Ought not Brother Asbury to act as General Assistant in America?

"He ought: first, on account of his age; second, because originally appointed by $\mathrm{Mr}$. Wesley; third, being joined with Messrs. Rankin and Shadford by express order from Mr. Wesley.

"Ques. I3. How far shall his power extend?

"On hearing every preacher for and against what is in debate, the right of determination shall rest with him, according to the minutes."

Twenty days later, May I8, I779, at Fluvanna, in the Broken Back Church, another conference was held for the Southern stations, at which seven preachers were admitted on trial. Extensive revivals had taken place in all parts of the connection not directly affected by the war, and a table of the members in the society showed 8577 , an increase of 2482 over the last year, and of the preachers, 49 . No statistics are given of New York. Philadelphia is credited with 89 members, the whole State of New Jersey with I40, and Pennsylvania, exclusive of Philadelphia, with

1 "Minutes of Conferences," vol. i., p. Io. 
90; Delaware with 795, Baltimore circuit with 900, and Virginia and North Carolina included nearly all the remainder.

The conference made short work of those who differed from one of its prudential regulations. "In what light shall we view those preachers who receive money by subscription? Ans. As excluded from the Methodist connection."

During I 779 troubles arose from a desire and determination among the people of the South to have the ordinances administered to them. This question had arisen in I 777 under the presidency of Rankin, and was postponed until the Conference of I 778, at which William Watters, the oldest American preacher, presided. The same question was discussed and "laid over until the next conference."

It was well understood by Asbury and Watters that the Southern brethren were determined to have the sacraments. Their arguments were strong: the war separated them from Wesley; most of the clergymen of the Church of England had fled the country, and the few that were left, with one or two exceptions, were without the spirit, and had thrown off in large part the semblance, of piety. The people generally were destitute of the Lord's Supper, and there was no one to baptize the children.

Watters endeavored at the conference at Fluvanna to dissuade the people from taking the matter into their own hands. After a considerable discussion they appointed from the oldest brethren a committee to ordain ministers. A change was made at this conference concerning the length of time that preachers should remain upon trial. Hitherto the practice had been to take a preacher upon trial for one year only, and then admit him into full membership; but the conference decided that the preachers who had been upon trial one year should remain upon trial until the next conference. 
The committee thus chosen ordained themselves and proceeded to ordain and set apart other ministers for the same purpose-that they might administer the holy ordinances to the church of Christ. 1 They went forth to their circuits as formerly, "and administered the sacraments wherever they went, provided the people were willing to partake with them." The leaders were zealous, and the greater part very devout; and most of the preachers in the South, and the larger part of the members, sympathized with the plan. However, "some of the old Methodists would not commune with them, but steadily adhered to their former customs." 2

Under the new plan the preachers were very successful in the South; many conversions took place, and a general spirit of liveliness and unction accompanied the work. But the preachers north of Virginia took a decided stand against the step, seeing in it danger of a separation, and the result was " that both parties trembled for the ark of God and shuddered at the thought of dividing the church of Christ." For a considerable period there seemed little ground to hope that they would ever recede from that plan. ${ }^{3}$

During Asbury's retirement he made the acquaintance and gained the friendship of the Rev. Dr. M'Gaw, an influential clergyman of the Church of England, through whom, in Dover, the capital of Delaware, Asbury was introduced to a number of families who subsequently became Methodists. Dr. M'Gaw soon afterward became rector of St. Paul's Church in Philadelphia, and so zealously espoused the cause of the Methodists that in 1779 "Forrest Chapel," the first Methodist chapel in the State, was erected in Dover through his efforts. ${ }^{4}$

The ninth Annual Conference was held in Baltimore,

1 Lee's " History of the Methodists," p. 69. 2 Ibid, p. 7o. 3 Ibid.

" It was afterward called "Thomas Chapel." 
April 24, 1780, and shows a decline in membership of 73, a gain in Philadelphia of 1 , a loss in Baltimore of 20 , and in ministers of 7 .

The important business transacted showed that the society was slowly developing into a denomination. A form of deed for the preaching-house was printed, and provisions made for the appointment of trustees. It was ordered that every traveling preacher should take a license at every conference; that Brother Asbury, on behalf of the conference, should sign these; that no local preacher or exhorter should presume to speak in public without a note of authority once every quarter (if required) from the assistant; that the preachers should speak before prayer to every person, one by one, in families where they lodged, " if time will permit, or give a family exhortation after reading a chapter."

Certain questions with the answers are so important that they must be given in full :

"Ques. 12. Shall we continue in close connection with the church, and press our people to a closer communion with her?

"Yes."

"Ques. 20. Does this whole conference disapprove the step our brethren have taken in Virginia?

"Yes.

"Ques. 21. Do we look upon them no longer as Methodists in connection with Mr. Wesley and us till they come back ? 1

"Agreed.

"Ques. 22. Shall Brothers Asbury, Garrettson, and Watters attend the Virginia Conference, and inform them of our proceedings in this, and receive their answer?

1 This refers to a partial separation which took place in Virginia on account of the ordinances. 
"Yes."

"Ques. 26. What must be the conditions of our union with our Virginia brethren?

"To suspend all their administrations for one year, and all meet together in Baltimore."

"Ques. I6. Ought not this conference to require those traveling preachers who hold slaves to give promises to set them free?

"Yes.

"Ques. I7. Does this conference acknowledge that slavery is contrary to the laws of God, man, and nature, and hurtful to society; contrary to the dictates of conscience and pure religion, and doing that which we would not that others should do to us and ours? Do we pass our disapprobation on all our friends who keep slaves, and advise their freedom?

"Yes."

"Ques. 23. Do we disapprove of the practice of distilling grain into liquor? Shall we disown our friends who will not renounce the practice?

"Yes."

A few days after the adjournment of the conference a deed was executed for ground on which to erect a chapel, which was speedily constructed sufficiently to admit of occupation for religious services, though it remained unfinished until two generations had passed away. It was forty-two by forty-eight feet, built of brick, two stories high, and had a vestry-room connected with it. In November of the same year, a floor having been laid and rough seats arranged, the first quarterly meeting was held in it, and a thousand people attended. It was built about a mile from Frederica, by Judge Barrett, and hence known as "Barrett's Chapel."

While it was being erected, a gentleman of the neigh- 
borhood wished to know what use was to be made of it. Being told that it was a place of worship for the Methodists, he said, "It is unnecessary to build such a house, for by the time the war is over, a corn-crib will hold them all." Its erection caused much opposition.

In the spring of 1780 , probably in the month of April, Asbury emerged from his retirement, which had lasted two years and one month, and, after meeting with the preachers in conference at Baltimore, made a tour through Virginia for the purpose of settling the difficulties concerning the ordinances. He had previously written to the leaders of the movement, and conceded that strong grounds existed for their views, and acknowledged that they were governed by high moral and spiritual considerations. It is clear that the Virginia preachers were for turning out of the society all who would not submit to their administration; that Asbury had been endeavoring to unite the Protestant Episcopal minister and the Methodists, but the dissenters exclaimed: "We don't want your unconverted ministers; the people will not receive them." 1 He then records a purpose to "turn out shortly among them." In pursuance of this plan he tarried with Mr. Gough at Perry Hall, preparing conditions for a partial reconciliation, in hopes of bringing about a real one. Describing his state of mind, he says, "I go with a heavy heart, and fear the violence of a party of positive men." Journeying southward with Freeborn Garrettson, they stayed at a hotel about forty miles from Baltimore. Garrettson talked with the landlord on the subject of religion, and prayed with him at night and in the morning, for he would not consent to call his family together. A high eulogium is pronounced upon Garrettson by Asbury: "Brother Garrettson will let no person escape a relig- 
ious lecture that comes in his way. Sure he is faithful, but what am I?" 1

When seventy miles on their way they were entertained by Mr. Arnold, of whom Asbury says: "We found the plague was begun; the good man Arnold was warm for the ordinances." At various points on the route he met the people, and says that they were full of the ordinances; and at last reached Mannakin-town, where the Virginia Conference had agreed to meet. Notwithstanding the embarrassing circumstances, Asbury "conducted himself with a cheerful freedom, but found that there was a suppression in heart and practice." He spoke to his countryman, John Dickins, and found him opposed to continuance in union with the Episcopal Church. Watters and Garrettson concurred, but all with whom they conversed were inflexible. The conference having assembled, Asbury, Watters, and Garrettson, afterward joined by Dromgoole, did not enter until specially invited. Asbury, being permitted to speak, read Wesley's "Thoughts against a Separation," showed his letters of instruction from Wesley, set before them the sentiments of the Delaware and Baltimore conferences, read the epistles that had passed between them, his letter to Gatch, and the answer of Dickins. After this discussion the preachers seemed still more estranged, and Asbury, Garrettson, Watters, and Dromgoole withdrew to deliberate on the condition offered, which was a suspension for one year of the measures which they had taken, that correspondence might be had with Wesley. For an hour the advocates of ordination deliberated, and answered that they could not submit to the terms of union.

Asbury says, "I then prepared to leave the house and go to a near neighbor's to lodge, under the heaviest cloud I ever felt in America." 2 He returned on Wednes-

1 “Asbury's Journal," vol, i., p. 366.

2 rbid., vol, i., p. 367 . 
day, the Ioth, to take leave of the conference, intending to start immediately for the North, and found " they were brought to an agreement while I had been praying, as with a broken heart, in the house we went to lodge at; and Brothers Watters and Garrettson had been praying upstairs where the conference sat." Well did Asbury conclude that "the hand of God has been greatly seen in all this," and adds: "There might have been twenty promising preachers and three thousand people seriously affected by this separation." 1

The Conference of I 78I began at Choptank, in the State of Delaware, April I6th, and adjourned to Baltimore on the 24th of the same month. Here thirty-nine of the preachers agreed to " preach the old Methodist doctrine, and strictly enforce the discipline, as contained in the 'Notes,' 'Sermons,' and 'Minutes' published by Mr. Wesley, so far as they respect both preachers and people, ... . and to discountenance a separation among either."

This conference began to talk about precedents, and asked about meeting at Choptank before going to Baltimore, to examine those who could not go to the latter place, and to provide supplies for circuits where the Lord is more immediately pouring out his Spirit. "Is there any precedent for this in the economy of Methodism?" To which the recorded answer is: "Yes; Mr. Wesley generally holds a conference in Ireland for the same purposes."

The rules passed were that no assistant should take a local preacher to travel in a circuit in the intervals of conference without consulting Asbury or the assistant near him; that no one, without similar consultation, should restore preaching to a house whence it was removed by his predecessor; that those applying to be received upon

1 "Asbury's Journal," vol. i., p. 367 . 
probation should be examined by the preachers; the first question to be asked being " whether they had been turned out"- -shows that many had been expelled.

The greatest revival of religion had been on the southern shore of Maryland and in some parts of Delaware. A large increase had been made in New Jersey and Pennsylvania, in fact throughout the entire connection, the sum of the members being 10,539, a gain of 2035, and the number of preachers 54, a gain of 12 . The Rev. Mr. Jarratt attended the conference, delivered several discourses, gave the preachers the benefit of his counsel, and administered baptism and the Lord's Supper. The probationary system was introduced, whereby candidates for reception into the society were tested and instructed for three months, and a rule was formed for settling financial disputes among the members.

Many of the members were drafted during that year, and when the militia were called out entered the army. The effects are sententiously described by Jesse Lee, who had personal knowledge of them: 1 "Some of them lost their lives, and some made shipwreck of the faith, and but few returned home with as much religion as they formerly possessed. Some of the Methodists were bound under conscience not to fight, and no threatenings could compel them to bear arms or hire a man to take their places. In consequence of this, some of them were ruhipped, some were fined, and some imprisoned; others were sent home, and many were much persecuted."

Numerous battles were fought in Virginia, and the general alarm often prevented the people from assembling; and when they met the conversation was principally upon the times and their disturbances. Before a meeting commenced the inquiry would be, "What is the news of the day?"

1 Lee's " History of the Methodists," p. 77. 
and this subject was resumed as soon as the exercises closed. One would say, "My son is killed;" another, "My husband is wounded," or "taken a prisoner," or "sick and likely to die." There being no papers or mails, all such information had to be given in conversation.

Notwithstanding this, in some parts of Virginia there were extensive revivals. Toward the close of the year the capture of Lord Cornwallis and his British army at Yorktown inspired hope that the war would soon end.

The tenth Annual Conference was held at Ellis's Preaching-house in Sussex County, Virginia, April I7, I782, and adjourned to Baltimore May 2 Ist. It had become necessary to have two conferences, one in the South and another in the North, the latter being of longer standing and composed of the older preachers; therefore, says Lee, ${ }^{1}$ "it was allowed greater privileges than that in the South, especially in making rules and forming regulations for the societies. Accordingly, when anything was agreed to in the Virginia Conference and afterward disapproved of in the Baltimore Conference, it was dropped; but if any rule was fixed and determined on at the latter, the preachers in the South were under the necessity of abiding by it."

It was determined at the Conference of $I 782$ to have two conferences in each year, and, to guard against disorderly preachers, a certificate was given to each containing the proviso that "the authority which this gives is limited to the next conference." A similar caution was attached to the certificates of local preachers. It was also decided that no member should move to another part of the country without a certificate from the assistant preacher.

Relatively to the future of Methodism the most important question was this: "Do the brethren in conference

1 Lee's "History of the Methodists," p. 78, 
unanimously choose Brother Asbury to act according to Mr. Wesley's original appointment and preside over the American conference and the whole work?

"Ans. Yes."

Times of meeting of the next year were fixed, and a special resolution was passed of acknowledgment to the Rev. Mr. Jarratt for his kind and friendly services to the preachers and people from the first entrance of the Methodists into Virginia; and the preachers in the South were advised to consult him in the absence of Brother Asbury and follow his advice. Arrangements were made for every assistant preacher or one of his helpers to travel with Asbury through his circuit. There were now I I,785 members, exclusive of the unreported number in $\mathrm{New}$ York.

Pursuant to the previous appointment, the eleventh Annual Conference assembled on the 6th of May, I 783, at Ellis's Preaching-house, and subsequently adjourned to Baltimore. There had been an increase of 23 in the number of ministers and 1955 members. Fourteen ministers were received on trial, among them Jesse Lee, forever afterward to be famous in Methodism.

A rule was passed extending to local preachers who held slaves contrary to laws which authorize their freedom in any of the United States.

For the first time the phrase "United States" appears in the minutes; for in April, I783, Congress issued a proclamation declaring the cessation of arms on land and sea, and enjoined its observance.

While the conference was in session in Baltimore, the whole country was infused with the spirit of jubilation; and, instead of providing for four fast-days, as had been done for some years, an inspiring question was answered: "How many days of thanksgiving shall we have for our 
public peace, temporal and spiritual prosperity, and for the glorious work of God?

"Ans. The first Thursdays in July and October."

Two fast-days also were provided-the first Fridays in January and April.

Nearly all the Methodist preachers were unmarried, and no direct provision had been made for the support of families. But now the question appears: "How many preachers' wives are to be provided for?" and the names of eleven are given, and the amount of money necessary assessed upon the different circuits, the sum appropriated being two hundred and sixty pounds sterling.

There was an important question relating to temperance : "Should our converts be permitted to make spirituous liquors, sell and drink them in drams?

"Ans. By no means; we think it wrong in its nature and consequences, and desire all our preachers to teach the people by precept and example to put away this evil."

Asbury, on receiving the news of peace, wrote in his "Journal": "I had various exercises of mind on the occasion: it may cause great changes to take place amongst us; some for the better, and some for the worse. It may make against the work of God; our preachers will be far more likely to settle in the world, and our people, by getting into trade and acquiring wealth, may drink into its spirit."

While no statistics are reported from New York, the name of that city as well as Norfolk, Va., reappears in the minutes, Samuel Spraggs and John Dickins being stationed at New York. The former was admitted on trial at the second conference, May 25, I 774; in 1778 his name disappears from the minutes, and does not reappear until I 783. For five consecutive years he was acting as pastor in New York. We are indebted for conclusive proof on this point to the researches of Dr. J. B. Wakeley, who learned by the old book of John Street Church that Mr. 
Spraggs was the preacher. The entries as given from February 26 , I 779 , reveal Revolutionary prices. The wood allowed him in 1782 for the single room which he occupied cost $£ 21$ 13s. 6d. sterling. His salary was $£ 137$ a year, and was paid regularly from May, 1778 , to June IO, 1783 , during the whole of which time the city of New York was under British martial law. When the British arrived, Daniel Ruff, the pastor, left the city, and John Mann preached gratuitously until Samuel Spraggs came. In I 783, when Mr. Spraggs and Mr. Dickins were appointed, the trustees settled finally with the former, having paid him $\$ 1302.50$, which, according to the book, was raised by public and class collections.

Wakeley accounts for the size of the collections by stating that most of the churches were converted into barracks, while the services were regularly held in Wesley Chapel. The congregations must have been very large, British officers as well as soldiers attending. The preacher was paid a larger salary than the people were able to pay before the war or after peace was proclaimed. The old book also gives an account of the money raised through the class collections as distinguished from that raised in the public collections, and this was so large as to show that the classes must have been well attended. Furthermore, in the expenditures evidence appears that the preacher's house was kept in order, the sexton's salary paid, and money appropriated for love-feasts and other peculiarities of Methodism.

Shortly after John Dickins arrived, Samuel Spraggs withdrew from the Methodists and joined the Church of England, becoming pastor of the ancient church in Elizabeth, N. Y. There he died, and " in that venerable church is a tablet erected to his memory." 1

Notwithstanding the large attendance, the membership

1 " Lost Chapters Recovered from the Early History of American Methodism," by J. B. Wakeley, D.D., chaps. xxix., xxx. 
had declined from 200 to 60 . Concerning Mr. Dickins, Mr. Asbury records, April 5th: "This day I prevailed with Brother Dickins to go to New York, where I expect him to be far more useful than in his present station."

Already persons claiming to be Methodists, and asking to be recognized as preachers, began to come from Europe, so that the Conference of $\mathrm{I} / 83$ found it necessary to protect itself, and did so under Question I2: "How shall we conduct ourselves toward any European Methodists, should they come to this continent?

"Ans. We will not receive them without. a letter of recommendation which we have no reason to doubt the truth of."

When the Conference of 1783 adjourned, Asbury resumed his travels. Very extraordinary opportunities opened before the preachers.

Certain modern writers upon Methodism have spoken slightingly of Jesse Lee's History, but without just cause. Considering the time when it was written, the peculiar character of the movement, the disturbed condition of the country during the greater part of the time comprehended in the history, and that Lee was first in the field, his history is worthy the name of a multum-in-parvo, containing many passages admirable in their freshness, clearness, and condensation, and made interesting by a quaintness of expression peculiar to the writer, and true to the genius of Methodism by the devout spirit everywhere exhibited and the topographical element frequently introduced.

The following account of the wonderful opportunities offered the preachers after the close of the Conference of 1783 is a fair illustration of the condensation and simplicity of his style:

"The Revolutionary War being now closed, and a gen- 
eral peace established, we could go into all parts of the country without fear; and we soon began to enlarge our borders, and to preach in many places where we had not been before. We soon saw the fruit of our labors in the new circuits and in various parts of the country, even in old places where we had preached in former years with but little success.

"One thing in particular that opened the way for the spreading of the gospel by our preachers was this: during the war, which had continued seven or eight years, many of the members of our societies had, through fear, necessity, or choice, moved into the back settlements and into new parts of the country; and as soon as the national peace was settled, and the way was open, they solicited us to come among them; and by their earnest and frequent petitions, both verbal and written, we were prevailed on and encouraged to go among them; and they were ready to receive us with open hands and willing hearts, and to cry out, 'Blessed is he that cometh in the name of the Lord." "1

The conference which began at Ellis's Preaching-house in Virginia, April 30, I 784, and ended at Baltimore, May 28 th, showed a wide distribution of the work and an increase of 1248 in the number of members. A rule was made determining who should attend the conferences-the assistants and those to be received into full connection. Previously notice had been given by Asbury and leading assistants to individuals orally or by correspondence. The greater strictness in administration concerning preachers must account for the slight increase (I) in the number. Twelve preachers were admitted on trial and four had desisted from traveling. A question was introduced, ever since repeated, and regarded as of great importance: "What preachers have died this year?" The names of

1 Lee's " History of the Methodists," pp. 84, 85. 
two, Henry Metcalf and William Wright, are recorded, but no reference is made to their characters. Seven new circuits were recorded-four in Virginia and three in North Juniata, Trenton, and Long Island. Many of the new societies were adapted to serve as nuclei of large churches.

Wesley had sent a letter in October, I783, which produced a profound impression on the connection.

“ Bristol, October $3,1783$.

"I. Let all of you be determined to abide by the Methodist doctrine and discipline, published in the four volumes of 'Sermons,' and the 'Notes upon the New Testament,' together with the large 'Minutes of Conference.'

" 2. Beware of preachers coming from Great Britain or Ireland without a full recommendation from me. Three of our traveling preachers here eagerly desired to go to America; but I could not approve of it by any means, because I am not satisfied that they thoroughly like either our discipline or our doctrine; I think they differ from our judgment in one or both. Therefore, if these or any others come without my recommendation, take care how you receive them.

" 3. Neither should you receive any preachers, however recommended, who will not be subject to the American conference and cheerfully conform to the minutes both of the American and English conferences.

"4. I do not wish our American brethren to receive any who make any difficulty on receiving Francis Asbury as the General Assistant.

"Undoubtedly the greatest danger to the work of God in America is likely to arise either from preachers coming from Europe, or from such as will arise from among yourselves, speaking perverse things, or bringing in among you new doctrines, particularly Calvinian. You should guard 
against this with all possible care, for it is far easier to keep them out than to thrust them out.

"I commend you all to the grace of God, and am "Your affectionate friend and brother, "JoHN WESLEY." 1

A rule was enacted embodying the principles stated in the foregoing letter.

To erect new chapels and pay debts a yearly subscription was to be made all through the circuits, and the preachers were instructed to "insist upon every member that is not supported by charity to give something." Preachers were warned to avoid superfluity in dress themselves, and speak frequently and faithfully against it. Converts who buy and sell slaves are to be expelled, if they buy with no other design than to hold them as slaves, if they have been previously warned. On no consideration should they be permitted to sell. Local preachers who, in the States where the laws permit it, will not emancipate their slaves, are to be borne with in Virginia another year, but suspended in Maryland, Delaware, Pennsylvania, and New Jersey. Singing was to be reformed by the "preachers who had any knowledge in the notes improving it, learning to sing true themselves and keeping close to Mr. Wesley's tunes and hymns."

The stern attitude of the conference toward traveling preachers on the subject of slavery is revealed by Question 22: "What shall be done with our traveling preachers who now are, or hereafter shall be, possessed of slaves, and refuse to emancipate them where the law permits?

"Ans. Employ them no more."

Three conferences were appointed for the next year. Prior to $\mathrm{I} 784$ the minutes had been taken but were 1 Bangs's " History of the Methodist Episcopal Church," vol. i., pp. I48, 149. 
kept in manuscript, not being printed until I795; but after I 784 the minutes were annually published.

Thomas Ware was present at this conference, and many years later wrote: ${ }^{1}$ "It was the first I attended. There was quite a number of preachers present. Although there were but few on whose heads time had begun to snow, yet several of them appeared to be wayworn and weather-beaten into premature old age. ... I doubt whether there has ever been a conference among us in which an equal number could be found in proportion to the whole so dead to the world and so gifted and enterprising as were present at that of I $784 . "$

The distribution of the members, compared with the subsequent growth of the denomination, was peculiar. The whole number of members reported was 14,988; of these about eleven percent. were north of Mason and Dixon's line and eighty-nine percent. south of it.

At this conference, with the wisdom which characterized Francis Asbury's appointments, the thirty-seven assistants were stationed at strategic points. Endowed by nature with a broad and comprehensive mind, he was able to consider a movement, a position, or a man with reference not only to local and transient, but to permanent and general, relations.

The Juniata circuit appears in the minutes. It covered a large region in the Tuscarora Mountains. Methodists had been scattered through that country from the earliest times. A local preacher named Crider had settled near the present town of Huntington, and founded a society. Robert Pennington had migrated from Delaware and settled in Center County, where he built a log chapel among the mountains, known seventy-five years afterward as "Father Pennington's Church." 2

\footnotetext{
1 "Sketches of Life and Travels of Thomas Ware."

2 Stevens's " History of the Methodist Episcopal Church."
} 

Wilson Lee, who joined the conference in 1784 , was sent to the Alleghany circuit, situated among the mountains of that name; its limits were not fixed, and during the year $\mathrm{I} 784$ he crossed and recrossed those lofty ranges many times.

William Glendenning, one of the preachers, had been devising a plan to lay Asbury aside, or at least to abridge his powers. Asbury records this fact, and also that "Mr. Wesley's letter settled the point, and all was happy." 1

As soon as the conference adjourned Asbury, as usual, began his travels. On the first day of July he began to ascend the Alleghany Mountains, following the route that Braddock took. The population was sparse, and on halting for the night he was obliged to occupy a bed with two other persons. He averaged thirty miles a day, preaching as he went. After traversing that region he turned toward Philadelphia, reaching the quarterly meeting on the 2 ist of July, still preaching almost daily. On Sunday, the I 5 th of August, he was so weak as to have to lie down the greater part of the day on the floor, but arose at the appointed time and preached to a thousand persons; rode the next day twenty miles to Burlington, and the next to Trenton, delivering sermons at both places.

Visiting the city of New York, he was much pleased, and records what he saw with unusual enthusiasm: "At New York we found the people alive to God; there are about one hundred in society, and, with those in Philadelphia, to my mind appear more like Methodists than I have ever yet seen them." This improvement was to be traced chiefly to the ability, system, and fidelity of John Dickins.

The strength of the convictions produced by the early Methodists, and their absorption in their work, cannot be

$$
1 \text { "Asbury's Journal," vol. i., p. } 473 .
$$


better illustrated than by an entry made by Asbury during this tour in Maryland: "Here B. T., who was a great churchman, after hearing Freeborn Garrettson a second time, was seized with conviction on his way home, and fell down in the road, and spent a great part of the night crying to God for mercy. It was suggested to him that his house was on fire. His answer was, 'It is better for me to lose my house than my soul.'"

Having crossed into Virginia, Asbury in five succeeding days rode one hundred miles, spent five hours in public discourses and ten in family and public prayer, and read two hundred pages in Young's works. On Sunday, the 7 th, he rode twelve miles to Snow Hill, Md., where the judge himself opened the court-house, and a large congregation of different denominations attended. Asbury's theme was "The Certainty, Universality, and Justice of God's Proceedings at the Day of Judgment." After seven days more of travel he reached Barrett's Chapel. 


\section{CHAPTER VIII.}

\section{BLENDED ROMANCE AND REALITY.}

METHODISM had now for eighteen years run like a fire to and fro in this continent, here through dry stubble, there almost quenched in swamps and along watercourses, again kindled at distant points by wind-blown sparks, until the land was dotted with societies, none of which dared to call themselves churches, and whose members were without the sacraments except as they received them from clergymen of the Church of England, who in many instances regarded them with indifference or contempt. Eighty-three called themselves preachers; none dared to style himself a minister. The term " pastor" was not in use among Methodists, nor were those now familiar words "deacon" and "elder" heard except in ecclesiastical controversies. A large proportion of the members had not been baptized.

The doctrines which these men preached were the same that those who had brought Methodism to this country had heard from Wesley and the few clergymen who sympathized with him, and his lay helpers; the experience to which they testified was the direct result of a firm belief in these doctrines; the spirit they manifested was the compound result of their belief in certain principles, and of the Holy Ghost, who produced His special fruits, which reflection and mere belief cannot originate or sus- 
tain: "love, joy, peace, long-suffering, gentleness, goodness, faith, meekness, temperance."

Methodists, lay and clerical, who had experienced what they professed hated evil and loved good with the same intensity; hence they were equally powerful in preaching against sin, guiding those who "would see Jesus," and quickening and edifying believers.

In endeavoring to understand the method and spirit of Methodism and their effects, we may follow one of these as he goes forth from a conference to his "appointment." $\mathrm{He}$ is without money or friends, and does not expect to find either church, society, choir, or salary, but has been told that at a certain point seventy-five miles on the way Brother B-lives. After journeying until his horse and himself are weary and famished, he asks a mildmannered man, whose house is by the roadside, where he attends church, and is met with cordiality and invited to share the frugal meal of the family. Seated at the table, having made his calling known, he may be asked to invoke the divine blessing; if so, he does it with an unction never before heard by his host, using an ordinary meal as a symbol of the bread that cometh down from above. If not asked he volunteers, and even greater fervor may characterize him under these circumstances. The dinner over, he begins to speak individually to the family on the subject of their souls' salvation. Some listen from mere curiosity; perhaps only one shows genuine interest; but he seeks an opportunity to pray, and before the prayer is ended all feel that a strange, even an awful, visitor has come among them.

Imagination predominates in new countries. Intelligence from the outer world seldom reaches the people; sermons are few and far between, often dull and sometimes frivolous. But here is a man who affirms what he knows, 
and feels as one might be expected to feel if what he preaches is true. He sings a hymn which expresses the feelings of the one or more affected by the truth, and as the plaintive strain rises on the air those who have any appreciation of music gather about; some that were disposed to ridicule him are impressed, and the children are fascinated.

If these results follow he is asked to come again. Such may be the influence of his words and songs that the host offers the use of his house for a service; the neighbors are notified, and it would be strange if two or three were not convicted and converted that very night. These are at once formed into a class, the most intelligent invested with the responsibility of leadership, and instructions given him.

$\mathrm{He}$ inquires the way to the residence of the brother to whom he is to report. His host replies that he has heard of him, that he is a good man, who has peculiar ideas of religion and will not have any profane swearers about his farm, which is thirty miles distant. Whereupon the preacher informs him that the views which he has been teaching there are those held by Brother $\mathrm{B}$ -

Counting B_'s house the center and this the circumference of his circuit, the preacher is filled with joy. His cordial reception he accepts as a seal to his ministry. God is with him. Had he, however, been driven away, had he been beaten with many stripes, he would have been equally convinced that God was with him, and would have proceeded on his pilgrimage singing and giving thanks that he was permitted to partake of the afflictions of Christ, and a score of times before his weary body found rest that night he would repeat to himself, "Blessed are ye when men shall revile you, and persecute you, and shall say all manner of evil against you falsely, for my sake."

When he arrives at Brother B-'s the people are assembled, the preacher welcomed, and his.opening discourse 
on some such passage as "I seek not yours, but you," is followed by a stirring account of the grace of God, which was magnified the night before, when he, a weary, lonely stranger, who had to say to the people as Peter said to the lame beggar, "Silver and gold have I none; but such as I have give I thee," was permitted to unfold to their astonished gaze the pearl of great price.

Such joyful news quickens the faith and enlarges the hope of every one present. He has also a message for those who have been attracted by curiosity. "Behold," he exclaims, "the Lamb of God, that taketh away the sin of the world!" But if there be a single scoffer he may exclaim, "Behold, ye despisers, and wonder, and perish : for I work a work in your days, a work which ye shall in no wise believe, though a man declare it unto you."

In less than four weeks in his circuit of sixty miles in diameter he has preached fifty sermons, formed ten classes, made hundreds of visits, and erected family altars in more than fifty houses. He writes to the nearest assistant, giving an account of the wonderful work of God and asking for a visit.

It is remarkable that among the twelve apostles of our Lord there was no similarity, except that of a common human nature; and at least as many as twelve distinct types can be traced among the eighty-three preachers who had assembled in the Conference of 1784 . Five of these are worthy of special characterization.

Benjamin Abbott was born in New Jersey. In his boyhood he was apprenticed in Philadelphia, but immediately fell into bad company, indulging in card-playing, cock-fighting, and other evil habits, so that his master and he separated before his time had expired. He then went to New Jersey and worked on a farm owned by one of his brothers. He married, and, receiving a small amount of 
money from his father's estate, rented a farm, which he cultivated. He worked hard and earned a comfortable support, but lived in open rebellion against God, drinking, fighting, swearing, and gambling.

$\mathrm{He}$ continued in a life of sin, though often, in meetings which he attended, alarmed by the Spirit of God, until the fortieth year of his life. His wife was a member of the Presbyterian Church, and in the habit of prayer. He respected her highly, but she did not profess to have any internal religious experience. Abbott subsequently said that till he met the Methodists he "had never heard either a man or a woman say that they had a pardoning love of God in their souls, or knew their sins were forgiven."

Like Joseph, Abbott was a dreamer, and frequently had visions in which he saw himself dead and doomed. For a while he would reform, but his impressions would wear off and he would return to his former practices.

Reports of a Methodist preacher's expected coming to the town attracted his attention; he went to hear him, and was deeply convicted of sin. Abbott's own words concerning this event are graphic:

"But I knew not the way to Christ for refuge, being ignorant of the nature both of conviction and conversion. But, blessed be God, he still gave me light, so that the work was deepened in my soul day by day. The preacher came to preach in our neighborhood, and I went to hear him again; it being a new thing in the place brought many together to hear him. Some were Presbyterians, some Baptists, and others without any professions of religion. He took his text and preached with power; the Word reached my heart in such a powerful manner that it shook every joint in my body; tears flowed in abundance, and I cried out for mercy, of which the people took notice, 
and many others were melted into tears. When the sermon was over the people flocked around the preacher and began to dispute with him about principles of religion. I said that there never was such preaching as this, but the people said, 'Abbott is going mad.' " 1

Thoughts of suicide often came to him. At night in a lonely wood he determined upon the act, but while searching for a suitable place he was deterred by an inward voice, which said, "This torment is nothing compared to hell." He drove home in greatest anxiety, imagining the tempter directly behind him. While listening to a Methodist preacher he became excited and cried, "Save, Lord, or I perish!" Then shame overcame him, and he felt that his neighbors despised him. At the close, however, he would have spoken to the preacher, but the latter was surrounded by a crowd disputing points of doctrine. That evening he established family prayer, greatly pleasing his wife. The next day he drove twelve miles to a Methodist meeting, and asked the preacher to baptize him, hoping this would banish his distress, for he had as yet no idea of justification by faith. In answer to a question he said to the preacher, "I am nothing but a poor, wretched, condemned sinner." The preacher comforted him with the promises of the gospel, told him that he was the one for whom Christ died or he would not have awakened him, and commanded him to believe.

In the night he woke from a troubled dream, and seemed to see the Lord Jesus with extended arms saying, "I died for you." In his journal he describes the effect: "The Scriptures were wonderfully opened to my understanding. . . . My heart felt as light as a bird, being relieved of that load of guilt which before had weighed down

1 " Experience and Gospel Labors of the Rev. Benjamin Abbott," by John F firth (Philadelphia, 1825). 
my spirits, and my body felt as active as when I was eighteen, so that the outward and inward man were both animated."

He explained the Scriptures to the family, and spent the day in telling all what God had done for him. The effect was thrilling. Some laughed, others cried, and a report was spread that he was "raving mad." A minister tried to deliver him from "the strong delusions of the devil," and Abbott began to think he might be right, but turned a little out of the road, knelt down in the wood, and prayed that if he was deceived God would undeceive him; and God said to him, "Why do you doubt? Is not Christ sufficient? Is he not able? Have you not felt his blood applied?"

Some time afterward he dreamed that he saw the preacher under whom he was awakened drunk and playing cards, his garments torn and defiled. He awoke and found it only a dream, but in three weeks learned that this man, having fallen into gross sins, had been expelled from the Connection. This was the first expulsion from the Methodist ministry. Abbott was sorely tempted, but while praying this passage of Scripture came to him, "Cursed is he that putteth his trust in the arm of flesh."

He now began to study the Bible. His wife closely watched him, and after some months she was genuinely converted under the preaching of Philip Gatch, and cried out, " Now I know what you told me is true, for the Lord hath pardoned my sins!"

The accounts of the results of Abbott's preaching are almost incredible. He obtained impressions and coined astonishing sentences as he preached. Once he cried out, "For aught I know there may be a murderer in this congregation." A man arose to leave the house, but fell, crying out that it was he, for he had killed a man fifteen years before. 
Multitudes that had heard Abbott swear and had seen him fight would now come to hear him preach. He was equally powerful in preaching to the whites, the Indians, and the negroes. Hundreds fell unconscious under his preaching. It was a common thing for scoffers, as he looked at them and denounced their iniquities, to fall prostrate.

His fame crossed the Atlantic, and philosophers and medical men in England discussed the question of his sanity. Southey ${ }^{1}$ says: "Benjamin Abbott not only threw his hearers into fits, but often fainted himself through the vehemence of his own prayers and preachments."

One day he went to a funeral where hundreds were collected. A clergyman of the English church read the liturgy, and then preached "a short, easy, smooth, soft sermon." A terrible thunder-storm was gathering, and huge clouds met over the house, which caused all the people to crowd into it, upstairs and down, to screen themselves from the storm. The minister asked Abbott if he would say something to the people. He rose upon one of the benches, and almost as soon as he began tremendous claps of thunder, exceeding anything that the people had ever heard, succeeded one another with appalling rapidity, and incessantly lightning flashed through the house in a terrifying manner. Abbott preached upon the judgment; setting before the people "the awful coming of Christ in all his splendor, with all the armies of heaven, to judge the world and to take vengeance on the ungodly." This storm continued above an hour, during the whole of which time he was appealing to the people, who screamed and clung to one another in mortal terror. Many were converted, and fourteen years afterward there were in that vicinity twelve witnesses of unimpeachable character who testified that their awakening was due to that sermon. 
On one occasion the daughter of a Quaker was earnestly crying for purity of heart. Her father came into the room and reminded $\mathrm{Mr}$. Abbott that the Lord is not in the earthquake nor in the whirlwind, but in the still, small voice. He replied, "Do you know what the earthquake means? It is the mighty thunder of God's voice from Mount Sinai; it is the divine law to drive us to Christ. And the whirlwind is the power of conviction, like the rushing of a mighty wind, tearing away every false hope, and stripping us of every plea, but, ' Give me Christ or else I die!',"

Southey ${ }^{1}$ devotes three pages to Benjamin Abbott; and with reference to his reply to the Quaker, Samuel Taylor Coleridge says: "And pertinently; though it would perhaps have been a reply better suited to the reprover had Abbott said, 'True, friend! but yet it was by God's ordinance that the earthquake and the whirlwind should go before the still, small voice.'"

Benjamin Abbott was an enthusiast, but neither a fanatic nor a lunatic. Considered in connection with his early life, the circumstances of his conversion, his temperament, and the view he took of the perils of the unsaved, of divine providence, the life of the apostles, and the power of the Holy Ghost, there appears a logical consistency between his methods and themes and the effects he sought to produce. While he believed that the power which prostrated men was the direct operation of God, he distinguished between those physical effects and the moral transformation produced.by the Spirit in conviction, conversion, and sanctification. In the midst of the uproar he would cry, "Saul also was among the prophets, but what became of Saul? Break off your iniquities by repentance!"

Abbott arrived at Judge White's house, where he met

1 "Life of Wesley," vol. ii. 
Asbury and a score of other preachers. They were astonished at his simplicity and power. His sermon in the chapel was overwhelming. Some sank to the floor, others fled from the place. Asbury sent him to the house of a neighboring gentleman for lodging during the night; but there while at family prayers three persons fell as dead under the singing of the hymn, one being the hostess herself, and under the prayer several others were prostrated; and the host himself, who had become a backslider, was restored. Three hours had passed before their mingled prayers and praises ceased.

John Dickins was in several particulars an entire contrast to this man: a good scholar in English, Latin, Greek, Hebrew, and mathematics; sensible; conscientious; a marvelous disciplinarian, uniting firmness with discrimination; a systematic expounder of the Word of God, yet with extraordinary cumulative unction in its application; an ecclesiastical legislator who without the loss of spirituality apprehended the relation of a religious community to the development of the New World.

Caleb B. Pedicord, who entered the ministry in 1773 , is introduced by Lednum to his readers thus:1 "Those who have seen Mr. Pedicord have testified to the beauty of his person, and this casket contained a jewel of the finest polish." He was a quiet, pathetic preacher, and probably converted under the preaching of Robert Strawbridge, as he was a native of Maryland. His life was spent in that State, Delaware, New Jersey, and vicinity. Early in his ministry he was "baptized unto Christ in blood," for soon after he began to preach he was assaulted on the highway in Dorchester County, Maryland, and beaten till the blood flowed. He found shelter in a neighboring house, and while his wounds were being washed a brother of the man

1 Stevens, vol. ii., p. 201. 
who had beaten him came in, and, learning the facts, mounted his horse, overtook his brother, and chastised him so severely that he promised never to molest another itinerant. Pedicord bore to his grave the scars received on that occasion.

Quiet as he was, he was able to encourage the thunderer, Abbott, whom he found thoroughly discouraged in $178 \mathrm{I}$ on a new circuit. Abbott's account so distressed him that he could not eat his breakfast, but retired to pray. In a few moments he returned and exclaimed, "This people will yet hunger and thirst for the Word of God," a prediction that was fulfilled in a few months by an amazing revival. Whether he sang or preached, his voice was probably never surpassed in influence over the hearer.

He was riding one evening to an appointment in Mount Holly, and not supposing that any one was within hearing, was singing:

I cannot, I cannot forbear

These passionate longings for home;

$\mathrm{Oh}$, when shall my spirit be there?

$\mathrm{Oh}$, when will the messenger come?

Thomas Ware, a young man who had served in the Revolutionary army, was wandering in an adjacent forest, and "was deeply touched not only with the melody of his voice, which was among the best he ever heard, but with the words, especially the last couplet." " After he ceased," says Ware, "I went out and followed him a great distance, hoping he would begin again. $\mathrm{He}$, however, stopped at the house of a Methodist and dismounted. I then concluded he must be a Methodist preacher and would probably preach that evening." That evening Ware heard him and entered into light.

He soon began to speak in public. Pedicord perceived the characteristics which made Ware afterward one 
of the most successful of preachers for fifty years, a founder of the dénomination from New Jersey to Tennessee, from Massachusetts to the Carolinas, and by his pen one of the best contributors to its early history. ${ }^{1}$

Pedicord wrote to Ware from Delaware, summoning him to the ministry. No history of American Methodism can be complete without this letter:

"He who claims all souls as his own and wills them to be saved does sometimes, from the common walks of life, choose men who have learned of him to be lowly in heart, and bids them go and invite the world to the great supper. The Lord is at this time carrying on a great and glorious work, chiefly by young men like yourself. Oh, come and share in the happy toil and in the great reward! Mark me! though seven winters have now passed over me, and much of the way has been dreary enough, yet God has been with me and kept me in the way, and often whispered, 'Thou art mine, and all I have is thine.' He has, moreover, given me sons, and daughters too, born not of the flesh but of God; and who can estimate the joy I have in one destined, I hope, to fill my place in the itinerant ranks when I am gone! Who then will say that mine was not a happy lot? 'Tis well you have made haste; much more than I can express have I wished you in the ranks before mine eyes have closed in death on all below. When Asbury pressed me to become an itinerant I said, ' God has called me to preach, and woe unto me if I preach not;' but I had no conviction that he had called me to itinerate. 'No conviction, my son,' said he to me sternly, 'that you should follow the direction of Him who commissioned you to preach? Has the charge given to the disciples, "Go and evangelize the world," been revoked? Is the world evangelized?' He said no more. I looked at

I Stevens's "History of the Methodist Episcopal Church," vol. ii. 
the world; it was not evangelized. The world must be evangelized; it should long since have been so, had all who professed to be ministers of Christ been such as were the first gospel preachers and professors; for who can contend with him who is Lord of lords and King of kings when they that are with him in the character of ministers and members are called and chosen and faithful? Here the drama ends not; but the time, we think, is near-even at the door. Nothing can kill the itinerant spirit which Wesley has inspired. It has lived through the Revolutionary War, and will live through all future time. Christendom will become more enlightened, will feel a divine impulse, and a way will be cast up on which itinerants may swiftly move, and in sufficient numbers to teach all nations the commands of God."

Pedicord was constantly subject to dejection. Once he concluded that he was not called to preach, and was about to return home, but happened to meet an aged colored woman, who told him that what he had said on a former occasion had been the means of awakening her and of bringing her to God. This dissipated his fears and doubts, for said he, "I thought it was better to gain one soul to Christ than to acquire all the riches of the world."

Jesse Lee was converted in Virginia in 1773 under the preaching of Robert Williams. His parents had opened their house for preaching, and they and their children were converted. Two of the sons became ministers. Jesse Lee developed untiring zeal, traveling on foot day and night to reach the various meetings of the extensive circuit. He was familiar with the extraordinary scenes that took place on the Brunswick circuit under the preaching of George Shadford, where "it was quite common for sinners to be seized with a trembling and shaking, and from that to fall down on the floor as if they were dead; and many have been 
convulsed from head to foot, while others have retained the use of their tongues so as to pray for mercy while they were lying helpless on the ground or floor. The Christians, too, were sometimes so overcome with the presence and love of God as not to be able to stand on their feet." 1

$\mathrm{He}$ continued to increase in fervor, as that general revival advanced, until $I 777$, when he removed to North Carolina. Previously, being very diffident, he had declined to speak in public, but there among strangers he gained more courage, and was soon appointed class-leader, then exhorter, and in 1779 preached his first sermon.

In 1780 he was drafted into the Revolutionary army. Then occurred a singular struggle. As a Christian and a preacher of the gospel he could not reconcile himself to kill one of his fellow-creatures or to bear arms. He determined, however, to go and to trust in the Lord. $\mathrm{He}$ was two weeks on the journey to the camp, and on the evening that he came in sight of it he prayed God to take his case in hand and support him in the test of his conscience. He was ordered on parade. The sergeant offered him a gun; he refused it. The lieutenant brought another; he would not take it. The lieutenant reported him to the colonel, and again presented the gun, but Lee refused to touch it. He was therefore delivered to the guard. The colonel remonstrated with him, but, being unable to move him, he was considered to be a fanatic or a lunatic, and left to himself. He began immediately to pray with the guard, and such was the influence of his praying and preaching that the people gathered around him to the number of hundreds. Soldiers brought straw, overcoats, and blankets for his bedding. He slept a few hours and then rose and began to sing. An innkeeper in the neighborhood heard him praying early in the morning, and besought him

1 Lee's " History of the Methodists," p. 53. 
to preach. He stood upon a bench and preached near the tent of the commanding officer. Great was the excitement, and before he finished officers as well as men were bathed in tears. Gentlemen went about to make a collection of money for him, at which Lee ran among the people begging them to desist.

The colonel had a long talk with him, and wished him to say what he could do, as they did not desire to oppress him. He replied that he was a friend to his country, and was ready to do anything he could for it except fighting. He was asked if he would be willing to drive the baggagewagon. He said he would. Then the colonel told him that their chief cook was a Methodist, and he could drive the wagon when upon the march, and might ride and eat with him; to this Lee agreed, whereupon he was released from guard. He remained in the army for four months, doing this work, and preaching whenever he could obtain an opportunity.

$\mathrm{He}$ was not ready, however, to become an itinerant preacher, but visited the Conference of 1782 , at the close of which Asbury inquired if he was willing to take a circuit. He declined, but intimated that he was at a loss what to do; that he feared that he was incompetent and would hurt the cause. Asbury, perceiving a number of the preachers standing in the yard, raised his voice and cried, "I am going to enlist Brother Lee!" Familiar with Lee's career in the army, one of them said, "What bounty do you give?" and Asbury replied, "Grace here and glory hereafter will be given him if he is faithful."

The influence of his preaching was equally great upon himself and upon the people. They would weep until he could not be heard, and at times he would weep and be utterly unable to speak. On such an occasion he said, "I found that love had tears as well as grief." 
He became one of the most versatile orators and conversers, alike at home in pathos, humor, and wit. Ware says that he preached with more ease than any other man he knew. In repartee he was never surpassed, and his moral courage, as exhibited in the army, was unbounded.

In their respective types these were the most eminent of the early Methodist preachers. With all their diversity there was a remarkable unity in doctrine, spirit, and experience; and, if there was variety in method, there was no mistaking a Methodist preacher or a Methodist for a communicant of any other denomination. When members of other bodies associated frequently with Methodists, caught their spirit and expressed their experiences in similar language, if they were mistaken for Methodists it was because the characteristics of the latter had obscured those of the communions in which they were trained.

Preachers of such marked types impressed upon the more plastic of their converts their own peculiarities; but in every revival, and almost in every class-meeting, some Christian arose who could never be an imitator, and unhampered by conventionalism or unchecked except in a general way by rules and rites formed under the operation of its semi-military discipline, or by the strong hand of its administrators. The ebullitions of zeal and peculiarities of expression of such Methodists gave to each local society, and to at least one local preacher on every circuit, a power of attraction which kept every community in a state of expectancy of something new and startling. Some of these eccentric characters were among the best men connected with the movement.

As they grew older their idiosyncrasies became less distinct, their exuberance of expression was chastened, 
but their zeal remained, and having begun as collectors of materials for wiser workmen they themselves became master builders.

The demonstrations which followed the preaching of Abbott, took place under that of Williams, were seen, in fact, wherever a genuine Methodist preached, for a time caused much controversy. By many, perhaps by most, Methodists they were supposed to be direct results of the power of the Holy Spirit, and manifest proofs of His presence and approval of the work. By a few their absence was construed into evidence of the disfavor of God and believed to be the result of backsliding. Some stigmatized those demonstrations as wild fanaticism, and others denounced them as hypocrisy.

Some constructed a theory to explain them on the hypothesis that they followed only exciting preachers like Abbott; but this was a baseless assumption. They occurred under the preaching of John Wesley, argumentative, precise, and logical, rarely losing his self-possession, not given to tears, before they appeared under George Whitefield. They also took place under the reading of the logical and metaphysical discourses of Jonathan Edwards. They defied the denunciations, threatenings, and appeals of Thomas Rankin, who abominated them as disorder. Another remarkable fact was that skeptics and opponents were as liable as others to succumb, so that it became dangerous for such in the pursuit of their inquiries to draw near to those who were engaging in prayer or to approach too near the fervent preacher.

By their recognition as proper, license was given to the fanatic and the impostor. The latter might seek to win the confidence of preachers and people by the loudness of his cries, the vehemence of his gestures, or his seeming unconsciousness; the former might mistake the condition 
into which he passed for the power of God, the seal of the divine approbation, and the evidence that he had passed from darkness in to light.

To those who search for an explanation of these phenomena, the fact that they have occurred under all forms of religion, true and false, is in importance second only to the fact that many of the subjects underwent no moral change, and that many who experienced the most radical moral changes were not subject to such seizures.

The psychological key to the problem is that concentrated attention, accompanied by strong religious emotion, produces a powerful impression upon the nervous system, the result being an agitation of the nerves throughout the body, the effects of which differ according to the constitution of the subject. In one relief is found in floods of tears, in another in hysterical laughter, in a third by unconsciousness, in a fourth by a partial loss of muscular action, with marked effects upon the operations of the mind; in yet another complete catalepsy may be produced, every muscle becoming rigid and so remaining for hours, while no impression can be made by ordinary means upon either the senses or the mind; in still another involuntary motions may be constantly made, lasting for hours together; while some temperaments can bear religious or any other kind of emotion without outward excitement and with no indication except an unusual calmness. These differences of susceptibility are seen outside the sphere of religion, and even among members of the same family.

It is also a law that the perception of the effects of emotion and proximity to those who are under the power thereof will produce upon many effects similar to those manifested before them, so that they will weep when others weep even though in no way related to the cause 
of grief. Thus great panics arise, and mental and moral epidemics. Thus crowds are transformed into murdercus mobs, guilty of deeds from which every individual when alone would have shrunk. Thus, in wild alarm, armies have been stampeded before forces which they could have overthrown without difficulty had they made a stand. It is not, however, so generally known that any special form of manifestation may become epidemic if believed to have a divine or even a naturally necessary origin, and be indefinitely repeated. This explains the permanence of different types, such as the Jumpers in Wales, Jerkers in the Southwestern States, the quaking from which the Friends received the name now generally applied to them, and, in a modified form, the tones of different denominations, many of whose members, without being aware of it, never speak upon the subject of religion except with the inflections and intonations which were common in the earlier and more susceptible period of the history of the body.

Wise administrators would not suppress tears under the preaching of the gospel, even in excess, lest the direction of the consciousness of the individual to his own state should divert his attention from the Word of God. In like manner, should such extraordinary results seem to follow the preaching of the gospel, only in extreme cases would it be wise to check them arbitrarily, since private instruction and an infusion of calmness into the manner of the minister would be adequate to preserve decorum and check fanaticism and make the rôle of the impostor more difficult.

The system of discipline adopted by the Methodists rested upon both a Scriptural and a philosophical basis. Converts were received on probation, and regular meetings were held for examination and instruction; consistency of conduct was required; exhorters and local preachers 
were licensed; where outward excitement predominated over inward spiritual grace, the subjects thereof were reproved, and if any became so boisterous as to defeat the end for which the services were held they were removed. Of such, when not suspected of imposture, Wesley was accustomed to write, "Oh, honest heart, but poor head!" and of those who plainly gave themselves up to rhapsodies as to a kind of luxury he said, "They are froth without substance."

Various factors were involved in producing the effects of Methodist preaching and methods: the personal influence of the preachers, exerted through their testimony, example, conversation, oratory, and discipline; the contact of the members in social life and in the almost continuous meetings; the hymns and prayers, and the reflex action of all upon each and of each upon all; the power of truth relative to the moral condition and needs of the hearer, and the tremendous concentrated effect of fixed ideas as the work spread and assemblies increased until they became vast open-air congresses; and under peculiarly favorable circumstances a new power was developed, resembling, in germs, the influence of smaller meetings, but so magnified as to seem almost a different force.

Beyond and above all this was the might of the Holy Spirit. Without His aid great results might have followed, a powerful organization have been formed, many reformations of outer life effected. But profound modifications of character, amazing developments of courage, and the almost ceaseless flow, through a long life, of religious joy approaching ecstasy, triumphing over the infirmities of the body, dissipating dejection, and often exhibited most overwhelmingly when mere human elements would have been wholly ineffectual to sustain it; and the preservation and growth of the fruits of the Spirit, and 
their correspondence with the plain teachings of God's Word, constitute proof of the divine origin of the movement as conclusive as that furnished when holy men of old spake not of themselves, but as they were moved by the Holy Ghost.

There were not wanting those who constructed finely woven theories to explain the results of Methodist preaching upon natural principles, and there were others who denied that these principles had any influence. Both were in error; the former by predicating of nature effects that it never did or could produce, the latter by denying to nature the vast power which really exists to create influences which seem to many to be supernatural. Had there been no influence beyond unassisted nature neither Christianity nor Methodism as a spiritual system could have become permanent. The Scriptures uniformly represent all the affections peculiar to the Christian life as fruits of the Spirit, teaching that spiritual regeneration is necessary to entering the kingdom of God. Certain truths are revealed and certain effects predicated through the operation of the Holy Spirit. All true Christians know that for a considerable period they reflected upon the letter of spiritual truth with little or no feeling. Many had been instructed in the principles of religion and might have written essays or prepared discourses on the most spiritual doctrines, but were without deep emotions. At intervals they were self-condemned and occasionally yearned for union with God, but as a rule they had no religious feeling - at least, none higher than admiration and esteem for the principles of truth in which they had been instructed. There came, however, a period when the deepest emotions of penitence filled their souls. This was succeeded by joyous hope and a strong and lasting inclination of their hearts toward the truth. 
None ever attained these fruits of the Spirit who sought them in the firm belief that they are simply natural results of reflection; nor can any one, acting upon the idea that all that is necessary is for him to think and converse, and right feelings will arise in his soul, succeed in attaining the experience of the Christian. If men did not need spiritual influences they would require only truth and examples for imitation ; their feelings would spontaneously follow and concur with their views of truth. The teaching of the Holy Spirit is that $\mathrm{He}$, and $\mathrm{He}$ alone, reestablishes and maintains the connection between the views and the feelings, so that the heart loves and cleaves to what the judgment approves.

Wherever the truth is preached the Holy Spirit strives to affect human hearts, and if those who listen yield, all the emotions which God approves and desires to produce spring up. If, however, the Spirit is quenched, there remain only the simple intellectual processes of thought, without radical changes of character. In that condition all natural effects may be produced. The man whose will does not submit to the will of God may become the subject of epidemic feeling and sink under what he believes to be the power of God.

Wesley and his followers were charged with teaching that the mind has an inward feeling which enables it to perceive the ordinary influences of God's Spirit so as to discern from whence they come. The Rev. Dr. Rutherforth, a distinguished clergyman of the Church of England, wrote a treatise in 1763 , one of the chapters of which was entitled "An Examination of the Doctrines of the Methodists Concerning Inward Feelings." Wesley saw it first in I 768 and immediately answered it. As few writers on the more extraordinary phenomena of Methodism appear to have read this elaborate discussion, and as it is one of the best 
examples of the clear distinctions which Wesley made and insisted upon, it is important to introduce certain passages:

"You state the question thus: 'Have we any reason to believe that the mind has an inward feeling which will enable it to perceive the ordinary influences of God's Spirit so as to discern from whence they come?' (p. I5):

"I answer: (I) The fruit of His ordinary influences are love, joy, peace, long-suffering, gentleness, meekness. (2) Whoever has these, inwardly feels them, and if he understands his Bible he discerns from whence they come. Observe, what he inwardly feels is these fruits themselves; whence they come he learns from the Bible. . . .

" 5. Mr. W. indeed 'endeavors to explain away the doctrine of the Methodists concerning inward feelings' (p. 25). That is, I plainly tell what I mean by those expressions. My words run thus: 'By feeling I mean being inwardly conscious of; by the operations of the Spirit I do not mean the manner in which He operates, but the graces which He operates, in a Christian.' And again: 'We believe that love, joy, peace, are inwardly felt or they have no being, and that men are satisfied they have grace, first by feeling these and afterward by their outward actions.' . . .

"6. But you will pin it upon me, whether I will or no, and that by three passages of my own writings: (I) 'Lucy Godshall felt the love of God in an unusual manner.' She did. I mean in an unusual degree. And what will you make of this? (2) "When he examined some of his disciples, and they related their "feeling the blood of Christ running upon their arms, or going down their throats, or poured like water upon their breast and heart," did he tell them that these circumstances were all the dreams of a heated imagination?' I did; I told them that these three circumstances, and several others of the same kind, 
were mere dreams, though some of those which they then related might be otherwise. I will tell you more: I was so disgusted at them for those dreams that I expelled them out of the society.

"The third passage is this: "We do speak of grace (meaning thereby the power of God, which worketh in us both to will and to do of his good pleasure) that it is as perceptible to the heart, while it confirms, refreshes, purifies, and sheds the love of God abroad therein, as sensible objects are to the senses' (p. 27). I do speak thus; and I mean thereby that the comfort which God administers, not His power distinct from it, the love and purity which He works, not His act of working distinguished from it, are as clearly discernible by the soul as outward objects by the senses. And I never so much as dreamed that any one could find any other meaning in the words." 1

In this early period of American Methodism the consummate wisdom of Francis Asbury, fully equal to that displayed by John Wesley, in distributing men of different gifts in suitable succession, was exhibited. After a few months under the influence of an evangelist of quenchless zeal a sound administrator was placed over the society, and the evangelist sent to a people where backsliding had occurred because the enemy had sown tares. No general ever stationed his troops with greater skill than Asbury displayed in the adjustment of ministerial supplies to the infant societies. He knew whom to trust, and, ceaselessly moving among the people, made changes without regard to the limitation of time, composed feuds by authority and counsels, rekindled dying interest or quenched the flames of fanaticism, extricated a brother from the consequences of his own imprudence or delivered a society from the control of an indiscreet administrator.

1 Wesley's "Works," vol. vii., pp. 498-500. 



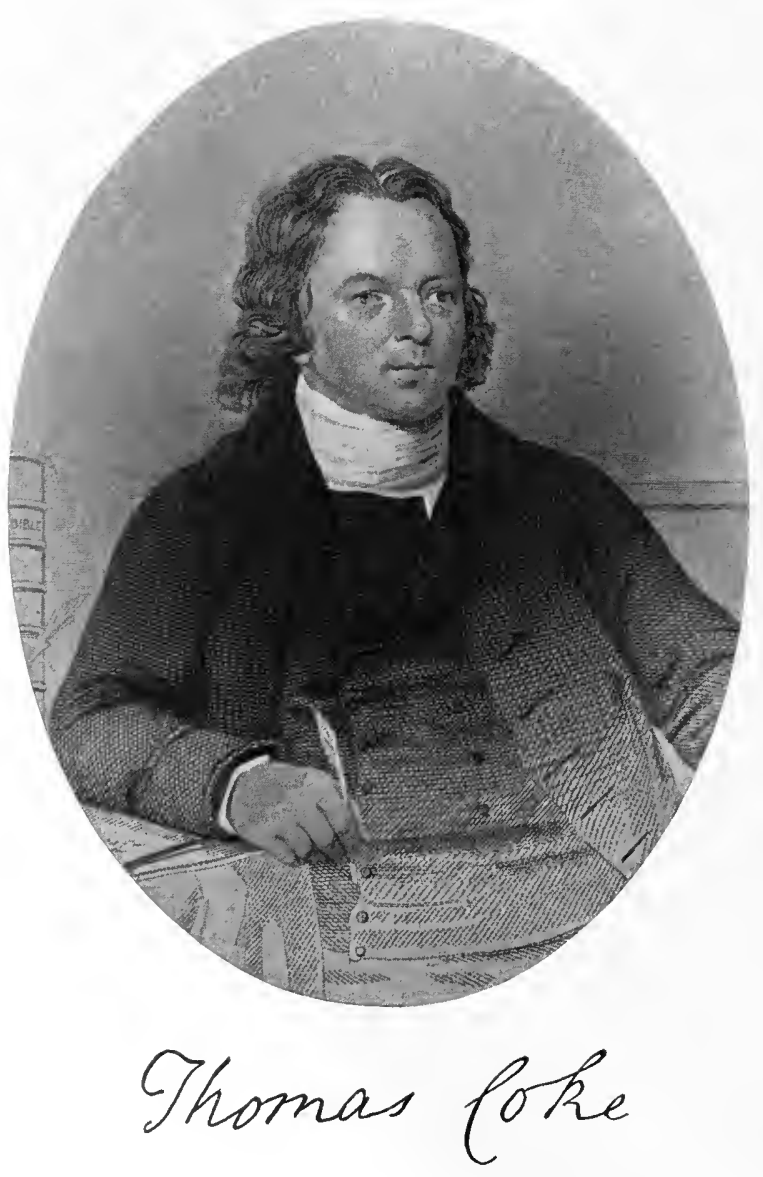




\section{CHAPTER IX.}

\section{ORGANIZATION OF THE METHODIST EPISCOPAL CHURCH.}

Thomas CoKe, LL.D., accompanied by Richard Whatcoat and Thomas Vasey, sailed on the I 8th of September, 1784, from Bristol, England, for New York.

Coke may with propriety be styled Wesley's minister plenipotentiary to American Methodism. He was a native of South Wales, an only child, and while an infant was bereaved of his father, an eminent surgeon who had several times filled the office of chief magistrate of his town. He was somewhat frivolous while a youth, but was not immoral and observed the outward forms of religion. When but sixteen he was entered a "gentleman commoner" at Jesus College in Oxford University, and was shocked by the looseness of life and the skepticism which prevailed at that seat of learning, but "by slow and imperceptible degrees he became a captive to those snares of infidelity which he had at first surveyed with detestation and horror." 1

He pursued a career of dissipation and folly, but was preserved from gross sins. From infidelity he was rescued by a powerful sermon preached by one who confessed to him that he did not believe the doctrines he had been defending. Such base inconsistency disgusted Coke and

1 Drew's "Life of Coke," (American edition, 1818). 
opened his eyes to the terrible consequences of rejecting the Word of God. He turned to the Dissertations of Bishop Sherlock, by reading which he was made a Christian in theory; and a treatise on "Regeneration" by Dr. Witherspoon kindled within him an intense desire to become a spiritual disciple.

At twenty-one he was chosen a common councilman for the borough of Brecon, a position which his father had held; and at twenty-five was elected chief magistrate, discharging the duties of that office with the highest repute for impartiality and fidelity. He intended to enter holy orders, but desired them rather as a means to promotion than as an opportunity for earnest work in the church of Christ.

The degree of Doctor of Civil Law was conferred upon him by Oxford, after an examination of his qualifications, on the I 7 th of June, I775. After several years he was appointed curate at South Petherton, and became an earnest preacher, displaying such power of eloquence that the church could not contain the crowds who sought to enter. He applied to the vestry for a gallery to be erected at the cost of the parish, but the request was refused. Having a fortune of his own, without further consultation he hired tradesmen and built the gallery at his own expense. ${ }^{1}$

At South Petherton he met Thomas Maxfield, a preacher sent out by Wesley, but who was ordained by the Bishop of Londonderry, who used this remarkable language: "Sir, I ordain you to assist that good man [Wesley], that he may not work himself to death."

The reputation of Coke having reached Maxfield, he sought an acquaintance, and explained to the young curate the necessity and nature of conversion, and gave him Alleine's "Alarm to the Unconverted," with the usual consequences. Coke, after becoming the subject of genuine

1 Drew's "Life of Coke," p. 16. 
regeneration, threw away his notes, and a new unction attended his word, so that on the occasion of his first extemporaneous sermon three were awakened. He delivered evening lectures in the villages, and introduced the singing of hymns into the church. Neighboring clergymen were offended at his violation of order and at the drawing away of their hearers. A charge was made against him and formally presented to Bishop Ross, who said that all he could do was to suspend him, which would make him a martyr, and therefore he thought it not best to do it. An accusation was then laid before the Bishop of Bath and Wells, but he confined himself to admonition. Finally the rector of the parish was besought to dismiss him, which he did. To consummate their triumph his enemies actually caused the parish bells "to chime him out of the doors." Coke stood in the street near the church, and when the service closed began to preach. A mob gathered, but two young persons of the best society supported him.

While the fame of these exciting events was spreading, John Wesley appeared not far from South Petherton. His "Journal" of August I 8, I 776, says: "I preached at Taunton, and afterward went with Mr. Brown to Kingston. Here I found a clergyman, Dr. Coke, late a gentleman commoner of Jesus College in Oxford, who came twenty miles on purpose to meet me. I had much conversation with him, and an union then began which I trust shall never end." 1

A year later Wesley writes: "I went forward to Taunton with Dr. Coke, who, being dismissed from his curacy, is determined to bid adieu to his honorable name and cast in his lot with us." 2

1 Drew's "Life of Coke," p. 29.

2 Wesley's "Works," vol. iv., p. 477. 
Coke now became one of the most attractive preachers in England, which is attributed by his biographer, the shrewd and metaphysical Samuel Drew, to his earnestness, activity, piety, unconquerable desire to do good, the melody of his voice, his engaging smile, the clerical character which he sustained, and "the peculiar unction with which God was pleased to attend his word."

Wesley appointed him to superintend the affairs of the London circuit in 1780 . Toward the close of the same year Wesley appointed him to visit the societies in Ireland alternately with himself once in every two years, leaving him free to take such journeys in England as prudence might direct.

After Coke left South Petherton a great change took place there in public opinion of him. His opponents everywhere met mournful countenances; " the poor had lost their benefactor, the people their pastor, the sick their comforter, and the wicked the only person that kept them in awe." On his revisiting the place his opponents were the first to chastise their own error. "Well," said they, "we chimed him out, and now we will atone for our folly by ringing him in."

There were in the United Kingdom three hundred and fifty-nine Methodist chapels by the year I 784. Soon after the erection of chapels began Wesley published a "model deed" by which they were to be held. This placed them in the hands of trustees "for the time being," under the restriction that Wesley and such others as he might from time to time appoint were to have free use of the premises to preach therein God's holy Word. If he died the same right was secured to his brother, and if his brother's decease occurred before that of William Grimshaw the same prerogatives were to belong to the latter. But after the three mentioned clergymen these prerogatives were transferred to "the Yearly Conference of the people called Methodists." 
In these deeds the proviso was introduced that the said persons appointed by the conference preach no other doctrines than those contained in Wesley's "Notes on the New Testament" and his four volumes of "Sermons." 1

The deed of John Street Church in the city of New York was drawn up on this model.

But in none of these deeds was "the Yearly Conference of the people called Methodists" defined, nor was there any declaration of the names of those who were then members of the said conference, nor any provision whereby the succession and identity thereof were to be continued. To supply these deficiencies Wesley carefully prepared a "Deed of Declaration," which was " executed on the 28th of February, I784, and enrolled in the High Court of Chancery." By this deed the legal conference is declared to consist of one hundred preachers, whose names and addresses are given. They and their successors are required forever to assemble once a year. The act of the majority is decreed to be the act of the whole. They are to have the power to fill vacancies. No act shall be valid unless forty be present. The conference shall never sit less than five days nor more than three weeks. Penalties for absence are provided, the power to expel recognized, conditions of admission stipulated, and everything necessary for the continuance of the conference, with final provision that if it "should ever be reduced under the number of forty members and so continue for three years successively, or if the members should decline or neglect to meet together annually during the space of three years, the conference of the people called Methodists should be extinguished, and all its powers, privileges, and advantages shall cease." The sixteenth and final provision was that "nothing in the deed should extinguish or lessen the life-

1 "Minutes of British Conference," vol. i., p. 41. 
estate of the said John Wesley or Charles Wesley, or either of them, in any of the chapels in which they now have or may have any estate or interest, power or authority, whatsoever."

Thomas Coke, himself a lawyer, had a prominent part in the preparation of the deed. He desired Mr. Clulow, a solicitor of Chancery Lane, to draw a statement of the case of the chapels as they then were, and "to present it to that very eminent counselor, Mr. Maddox, for his opinion." Maddox replied that the law would not recognize the conference in the state in which it stood at that time, and consequently that there was no central point which might preserve the connection from splitting into a thousand pieces after the death of Mr. Wesley. Dr. Coke read this opinion to the conference in 1783 . As soon as that conference was ended Wesley authorized Coke to draw up, with the assistance of Clulow, all the leading parts of a proposed Deed of Declaration.

Coke differed from Wesley upon the question of limiting the number of the preachers to one hundred, and believed that every preacher in full connection should be a member of the conference.

Had the American colonies failed to achieve their independence, for many years-perhaps till now-the government of all the Methodist chapels, remaining in connection with the societies established by Wesley, would be invested in the Yearly Conference, to which would, no doubt, be sent representatives from all parts of the British dominion.

Toward the close of the Revolutionary War Francis Asbury kept John Wesley advised of the progress of events in the United States, and especially dwelt upon the need of the sacraments; thousands of the members had not partaken of the holy communion for years, some indeed never, and their children generally were unbaptized. 


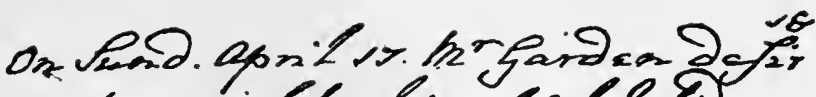

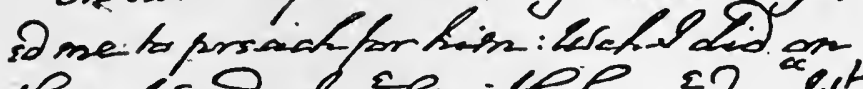

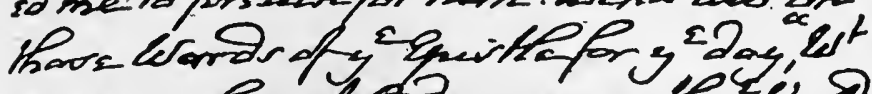

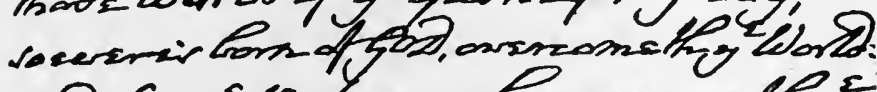

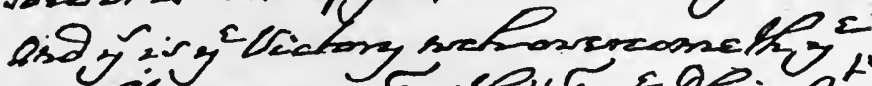

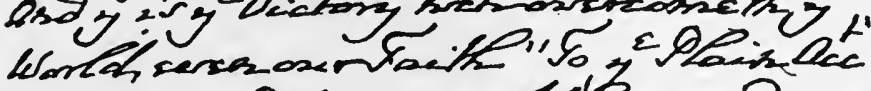

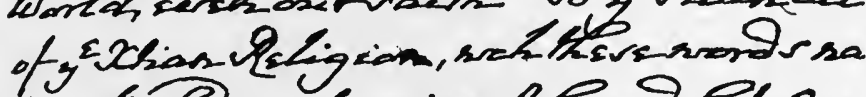

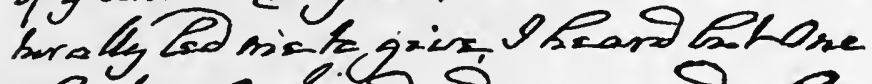

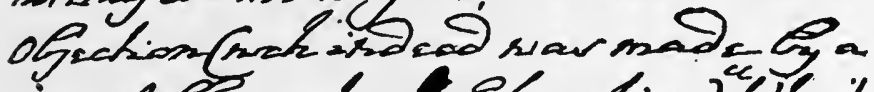

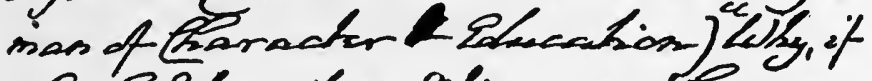

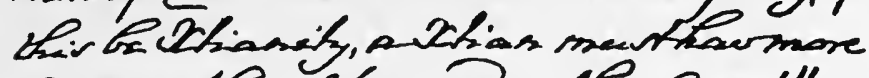

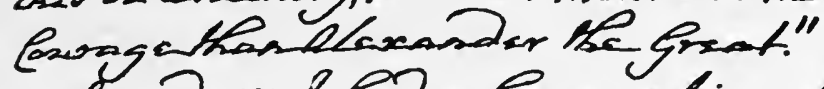

mond. v8. Ifad - Gaversuation of

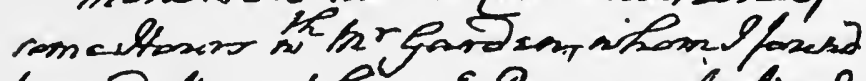

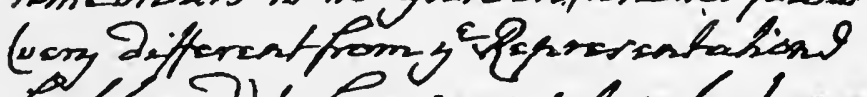
had hrand) to Ren mannotomly of

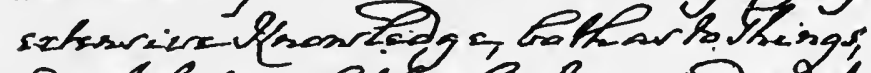

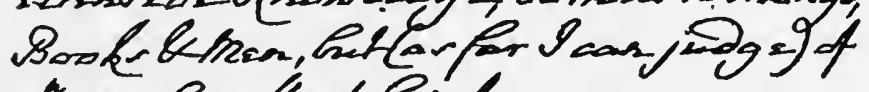
Docallant pisint.

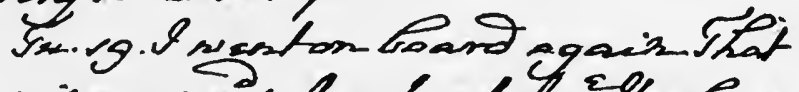

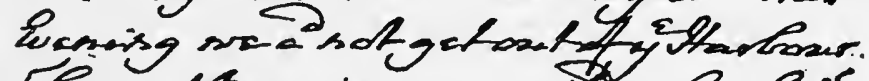

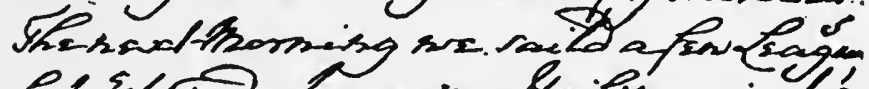

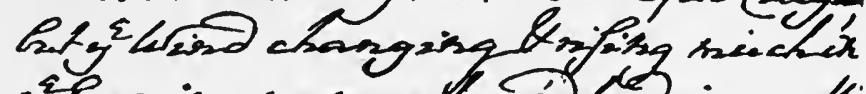

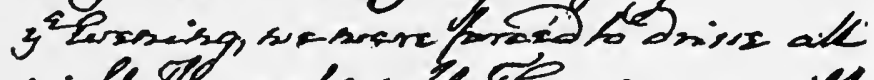

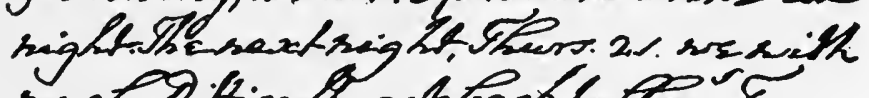

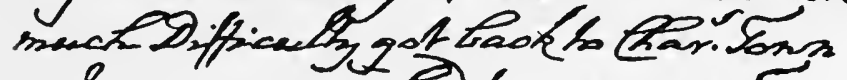

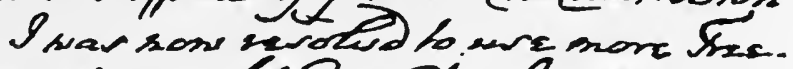

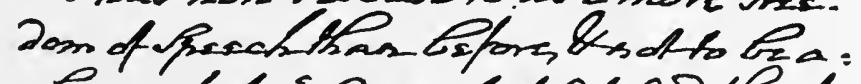

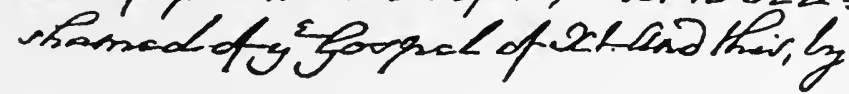

FACSIMILE OF PAGE OF WESLEY'S JOURNAL. 
.

$$
\text { . }
$$


He concluded, after protracted reflection, that these societies should be organized into a church under an episcopal form of government, and resolved to confer upon his preachers in the United States authority to ordain deacons and presbyters or elders, to administer the sacraments, and also to ordain superintendents from among the elders.

No single act or series of acts performed by John Wesley exposed him to such animadversion, or occasioned so much discussion, as the preparation which he made for this momentous change in American Methodism.

The documents extant upon this subject demonstrate the conduct of Wesley to be in perfect accord with his principles, often avowed during more than forty years, and never retracted.

What then did Wesley do, and what did he intend to accomplish?

In February, I 784, John Wesley invited Coke into his private chamber, and after some general conversation addressed him in nearly the following manner:

"As the Revolution in America had separated the United States from the mother country forever, and the Episcopal establishment was utterly abolished, the societies had been represented to him in a most deplorable condition. That an appeal had also been made to him through Mr. Asbury, in which he was requested to provide for them some mode of church government suited to their exigencies; and that, having long and seriously revolved the subject in his thoughts, he intended to adopt the plan which he was now about to unfold. That, as he had invariably endeavored in every step he had taken to keep as closely to the Bible as possible, so on the present occasion he hoped he was not about to deviate from it. That, keeping his eye upon the conduct of the primitive churches in the ages of unadulterated Christianity, he had much ad- 
mired the mode of ordaining bishops which the church of Alexandria had practiced. That, to preserve its purity, that church would never suffer the interference of a foreign bishop in any of their ordinations; but that the presbyters of that venerable apostolic church, on the death of a bishop, exercised the right of ordaining another from their own body, by the laying on of their own hands, and that this practice continued among them for two hundred years, till the days of Dionysius. And finally, that, being himself a presbyter, he wished Dr. Coke to accept ordination from his hands, and to proceed in that character to the continent of America, to superintend the societies in the United States." 1

Drew would neither have represented his own composition as a quotation, nor failed to credit this passage to Wesley had it been derived from him; hence it must be Coke's own words.

$\mathrm{He}$ was startled by a measure so unprecedented in modern days, and expressed doubts as to the validity of Wesley's authority. In the course of two months, however, he wrote the latter that his objections were silenced; and at the next conference, held in Leeds, I 784, Wesley stated his intentions to the preachers, which he records in his "Journal" as follows: "Being now clear in my own mind, I took a step which I had long weighed in my mind, and appointed Mr. Whatcoat and Mr. Vasey to go and serve the desolate sheep in America. Thursday, 2d, I added to them three more, which I verily believe will be much to the glory of God."

When the conference ended Wesley went to Bristol, and Coke to London, to make arrangements for his departure ; but he received a letter from Wesley requesting him to

1 Drew's " Life of Coke," pp. 63, 64. 
come at once to Bristol to receive greater powers, and to bring with him Mr. Creighton, a regularly ordained minister, who had long assisted Wesley in London and elsewhere.

At Bristol, Wesley, assisted by Coke and the Rev. James Creighton, ordained Richard Whatcoat and Thomas Vasey presbyters for America, and ordained Coke a superintendent, giving him under his hand and seal this certificate, of which the original, in Wesley's handwriting, is extant:

"To all to whom these presents shall come, John Wesley, late fellow of Lincoln College in Oxford, presbyter of the Church of England, sendeth greeting.

"Whereas many of the people in the Southern provinces of North America, who desire to continue under my care, and still adhere to the doctrines and discipline of the Church of England, are greatly distressed for want of ministers to administer the sacraments of baptism and the Lord's Supper according to the usage of the said church; and whereas there does not appear to be any other way of supplying them with ministers;

"Know all men, that I, John Wesley, think myself to be providentially called, at this time, to set apart some persons for the work of the ministry in America. And, therefore, under the protection of Almighty God, and with a single eye to his glory, I have this day set apart as a superintendent, by the imposition of my hands and prayer (being assisted by other ordained ministers), Thomas Coke, Doctor of Civil Law, a presbyter of the Church of England, and a man whom I judge to be well qualified for that great work. And I do hereby recommend him to all whom it may concern, as a fit person to preside over the flock of Christ. In testimony whereof, I have hereunto set my 
hand and seal, this second day of September, in the year of our Lord one thousand seven hundred and eighty-four. "JOHN WESLEY." 1

He then wrote a letter intended to explain the grounds on which he had taken this step, which letter he instructed Coke to print and circulate among the societies upon his arrival in America.

\section{"To Dr. Coke, Mr. Asbury, and our brethren in North America.}

"By a very uncommon train of providences many of the provinces of North America are totally disjoined from the mother country and erected into independent States. The English government has no authority over them, either civil or ecclesiastical, any more than over the states of Holland. A civil authority is exercised over them, partly by the Congress, partly by the provincial assemblies. But no one either exercises or claims any ecclesiastical authority at all. In this peculiar situation some thousands of the inhabitants of these States desire my advice, and in compliance with their desire I have drawn up a little sketch.

"Lord King's account of the primitive church convinced me many years ago that bishops and presbyters are the same order, and consequently have the same right to ordain. For many years I have been importuned, from time to time, to exercise this right by ordaining part of our traveling preachers. But I have still refused; not only for peace' sake, but because I was determined as little as possible to violate the established order of the national church to which I belonged.

1 Drew's "Life of Coke," p. 66. Facsimile of this was exhibited at the first Ecumenical Conference, in London, I88r. 
"But the case is widely different between England and North America. Here there are bishops who have a legal jurisdiction. In America there are none, neither any parish minister. So that for some hundreds of miles together there-is none either to baptize or to administer the Lord's Supper. Here, therefore, my scruples are at an end ; and I conceive myself at full liberty, as I violate no order and invade no man's right by appointing and sending laborers into the harvest.

"I have accordingly appointed Dr. Coke and Mr. Fran. cis Asbury to be joint superintendents over our brethren in North America; as also Richard Whatcoat and Thomas Vasey to act as elders among them, by baptizing and administering the Lord's Supper. And I have prepared a liturgy, little differing from that of the Church of England (I think the best constituted national church in the world), which I advise all the traveling preachers to use on the Lord's day in all the congregations, reading the Litany only on Wednesdays and Fridays, and praying extempore on all other days. I also advise the elders to administer the Supper of the Lord on every Lord's day.

"If any.one will point out a more rational and Scriptural way of feeding and guiding these poor sheep in the wilderness, I will gladly embrace it. At present I cannot see any better method than that I have taken.

"It has indeed been proposed to desire the English bishops to ordain part of our preachers for America. But to this I object: I. I desired the Bishop of London to ordain one, but could not prevail. 2. If they consented, we know the slowness of their proceedings; but the matter admits of no delay. 3. If they would ordain them now, they would expect to govern them. And how grievously would this entangle us! 4. As our American brethren are now totally disentangled, both from the state and the 
English hierarchy, we dare not entangle them again, either with the one or the other. They are now at full liberty simply to follow the Scriptures and the primitive church. And we judge it best that they should stand fast in that liberty wherewith God has so strangely made them free.

"John WESLEY." 1

Bearing these credentials, Coke and his companions sailed for the United States.

Thirty-eight years before the ordination of Coke Wesley wrote :

"Monday, 2oth, I 746, January, I set out for Bristol. On the road I read over Lord King's account of the primitive church. In spite of the vehement prejudice of my education, I was ready to believe that this was a fair and impartial draft; but if so, it would follow that bishops and presbyters are (essentially) of one order, and that originally every Christian congregation was a church independent of all others!"'2

Ten years after this entry Wesley wrote to the Rev. Mr. Clarke: "As to my own judgment, I still believe "the episcopal form of church government to be Scriptural and apostolic.' I mean, well agreeing with the practice and writings of the apostles. But that it is prescribed in Scripture I do not believe. This opinion, which I once zealously espoused, I have been heartily ashamed of ever since I read Bishop Stillingfleet's 'Irenicon.' I think he has unanswerably proved that 'neither Christ nor his apostles prescribe any particular form of church government; and that the plea of divine right for diocesan episcopacy was never heard of in the primitive Church." " 3

1 Wesley's “Works," vol. vii., pp. 311, 312.

2 Ibid., vol. iii., p. 363 .

s Ibid., vol. vii., p. 284 . 
A similar reference to Bishop Stillingfleet was made in a letter, dated April I 8, i 76 I. ${ }^{1}$

Wesley was thoroughly acquainted with the primitive church, and constantly attempted to reproduce it.

The best statement of his position is: "Wesley did not pretend to ordain bishops in the modern sense, but only according to his view of primitive episcopacy, . . . founded upon the principle of bishops and presbyters being of the same degree, a more extended office only being assigned to the former, as in the primitive church. For, though nothing can be more obvious than that the primitive pastors are called bishops or presbyters indiscriminately in the New Testament, yet at an early period those presbyters were, by way of distinction, denominated bishops, who presided in the meetings of presbyters, and were finally invested with the government of several churches, with their respective presbyteries; so that two offices were then, as in this case, grafted upon the same order." 2

The allegation that Wesley was mentally enfeebled by extreme age is unfounded.

Canon Overton's last chapter is entitled "Old Age and Death," for which title he thus apologizes: "In ordinary cases it would be rather late to date the commencement of a man's old age from his eighty-second year; but in this case we rather owe him an apology for venturing to call him an old man so soon. He was still a youth, both in mind and body." 3 And though utterly opposed to Wesley's action, he has the candor to say, "It has been said that John Wesley's mental powers were failing when he began to 'set apart' his preachers; and Charles Wesley himself has countenanced the idea by exclaiming, "'Twas

1 Wesley's "Works," vol. vii., p. 30r.

2 Watson's "Life of Wesley," p. 247.

3 Overton's "John Wesley," p. 193. 
age that made the breach, not he!' But there really appear to be no traces of mental decay in any other respects." 1

The simple fact is that for more than forty years Wesley held the views upon which he now acted. He had not, however, applied them in England, for almost, perhaps

- quite to the last, he hoped that English Methodism would be recognized by the Church of England, in a manner compatible with its continued existence and growth, as a revival of pure Christianity.

The voyage of Coke and his companions was tempestuous, but their course on shipboard resembled that of Wesley in his journey to Georgia many years before. They set apart a given hour for morning prayers, which the sailors attended, and on successive Sundays discourses were preached, which were listened to with earnest attention.

They landed in New York on the $3 \mathrm{~d}$ of November, and repaired to the residence of a trustee of the John Street Church. John Dickins, the pastor, who had been strenuous in demanding the right to administer the sacraments, was delighted with the purpose of their coming. The same night and for several successive days Coke preached, and then went to Philadelphia, where he was invited to preach in the English churches, receiving calls, among others from Dr. White, afterward bishop of the Protestant Episcopal Church, and also from the governor of the State, whom Coke describes as a "gentlemanly friend to literature, toleration, and to vital Christianity," and " an acquaintance of Wesley, and an admirer of the writings of Fletcher of Madeley.'

In Delaware Coke was the guest of Judge Bassett, who, though not a member of the Methodist Society, was erect-

1 Overton's "John Wesley," p. 206. 
ing a chapel at his own expense. On Sunday, the 14th, at Judge Bassett's, he met Freeborn Garrettson, and repaired to a chapel in the midst of a forest, finding a great concourse of people, to whom he preached, afterward administering the "Supper of the Lord" to more than five hundred. It was a Quarterly Meeting, and fifteen preachers were present.

Drew's description of what occurred after the sermon is this: "Scarcely, however, had he finished his sermon before he perceived a plainly dressed, robust, but venerablelooking man moving through the congregation and making his way to the pulpit; on ascending the pulpit, he clasped the doctor in his arms, and, without making himself known by words, accosted him with the holy salutation of primitive Christianity. This venerable man was Mr. Asbury." 1

These were Asbury's impressions of the interview: "Having had no opportunity of conversing with them before public worship, I was greatly surprised to see Brother Whatcoat assist by taking the cup in the administration of the sacrament. I was shocked when first informed of the intention of these my brethren in coming to this country ; it may be of God. My answer then was, if the preachers unanimously choose me, I shall not act in the capacity I have hitherto done by Mr. Wesley's appointment. The design of organizing the Methodists into an Independent Episcopal Church was opened to the preachers present, and it was agreed to call a general conference, to meet at Baltimore the ensuing Christmas." 2

Freeborn Garrettson was sent "like an arrow over North and South," with instructions to send messengers to right and left, and gather all the preachers in Baltimore on Christmas eve. Asbury drew up for Coke a route of about a thousand miles, to be traversed in the six weeks interven. 1 " Life of Coke." 2 "Asbury's Journal," vol. i., p. 484 . 
ing, "appropriated an excellent horse to him, and gave him his black, Harry by name." The full name of this brother of African descent was Harry Hosier. Asbury had found him serviceable to himself in many ways, and specially useful by his addresses to those of his own race.

At this their first interview Coke and Asbury agreed to unite their endeavors to establish " a school or college."

Coke traveled from Barrett's Chapel to the residence of Judge White, preaching every day. He utilized "Harry" as a preacher, and writes that he "really believes him one of the best preachers in the world." In this opinion he agreed with Dr. Benjamin Rush, who said, "that, making allowance for his illiteracy (he was unable to read), he was the greatest orator in America."

Thomas Ware remarks of Coke that he "was the best speaker in a private circle or on the conference floor he ever heard, but his voice was too weak to command with ease a very large audience. Scholarly men were delighted with him, and said that he spoke the purest English they ever heard."

Asbury continued his journeys over the Western Shore of Maryland, accompanied by Whatcoat and Vasey. At Abingdon they met Coke, and also William Black, the founder of Methodism in Nova Scotia, who was looking for ministerial help for that province. They arrived at Perry Hall on the I Ith of December, with the exception of Whatcoat, who came three days later. On Friday, the 24th of December, I784, the guests of Perry Hall rode into Baltimore. ${ }^{1}$

Garrettson had been so successful in notifying the preachers of the coming conference and its purpose that

1 Discrepancies concerning the date of this important event are numerous. Bangs and Wakeley say the 25th, Lee the $27 \mathrm{th}$, and Asbury, Coke, and Whatcoat the $24^{\text {th }}$. 


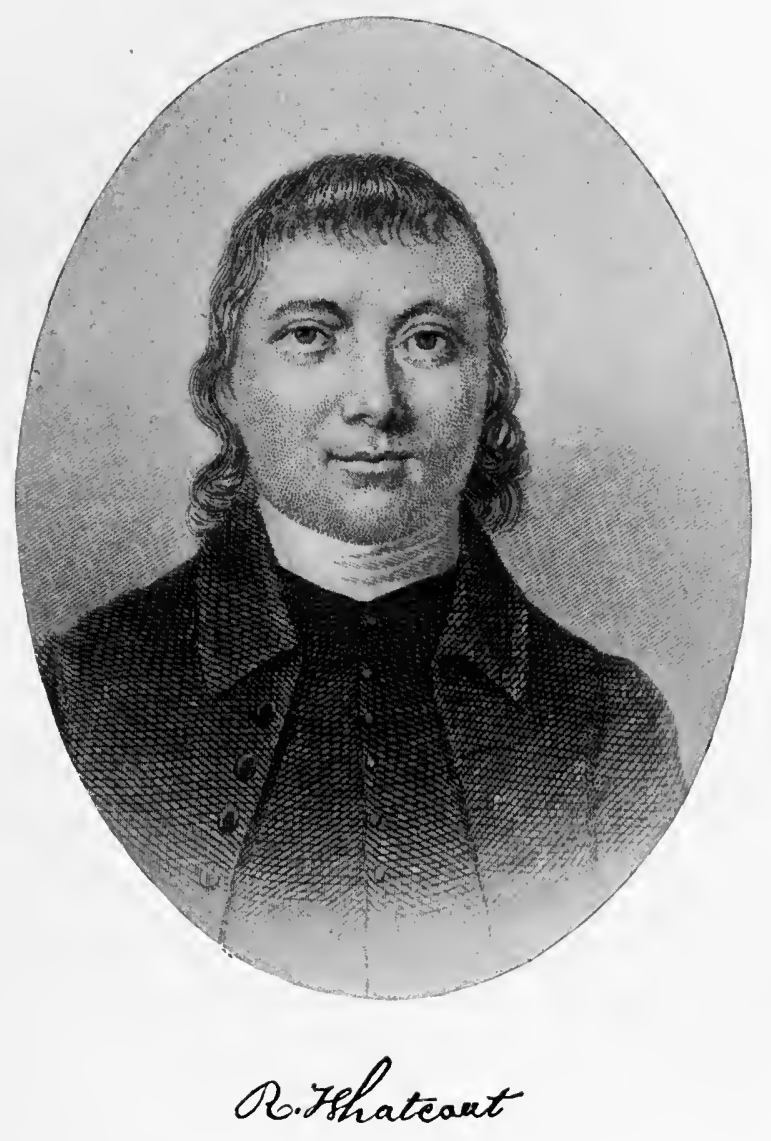



sixty were present. Wesley's letter having been solemnly read, Asbury records: "It was agreed to form ourselves into an Episcopal Church, and to have superintendents, elders, and deacons."

Lee says that, though Asbury was appointed a superintendent by Wesley, "he would not submit to be ordained unless he could be voted in by the conference; when it was put to vote he was unanimously chosen." Thomas Coke was also unanimously elected a superintendent.

Whatcoat's account is: "We agreed to form a Methodist Episcopal Church, in which the liturgy (as presented by the Rev. John Wesley) should be read, and the sacraments be administered by a superintendent, elders, and deacons, who shall be ordained by a presbytery, using the Episcopal form, as prescribed in the Rev. Mr. Wesley's prayer-book. Persons to be ordained are to be named by the superintendent, elected by the conference, and ordained by the imposition of the hand of the superintendent and elders; the superintendent has a negative voice." 1

Asbury was ordained deacon by Coke, assisted by Vasey and Whatcoat, on the second day of the conference. On Sunday he was ordained an elder, and on Monday consecrated superintendent. At his request Philip William Otterbein, of the German church, assisted in the ordination.

The discourse preached by Coke on the occasion of the ordination of Asbury kindled the most lively emotions among the Methodists present, and deeply impressed the multitude. Several deacons were ordained on Friday, and on Sunday, the $2 \mathrm{~d}$ of January, twelve or thirteen elders.

The first Discipline of the Methodist Episcopal Church was adopted by this conference. "This was substantially the same with the Large Minutes, the principal alterations

1 Italics Whatcoat's. Phœbus's "Memoirs of Whatcoat," p. 2 I. 
being only such as were necessary to adapt it to the state of things in America." 1

The second and other important questions are here printed in full :

"Ques. 2. What can be done in order to the future union of the Methodists?

"Ans. During the life of the Rev. Mr. Wesley, we acknowledge ourselves his sons in the gospel, ready in matters belonging to church government to obey his commands. And we do engage, after his death, to do everything that we judge consistent with the cause of religion in America and the political interests of these States to preserve and promote our union with the Methodists in Europe.

"Ques. 3. As the ecclesiastical as well as civil affairs of these United States have passed through a very considerable change by the Revolution, what plan of church government shall we hereafter pursue?

"Ans. We will form ourselves into an Episcopal Church, under the direction of superintendents, elders, deacons, and helpers, according to the forms of ordination annexed to our liturgy, and the Form of Discipline set forth in these minutes."

"Ques. 23. May our ministers or traveling preachers drink spirituous liquors?

"Ans. By no means, unless it be medicinally."

"Ques. 26. What is the office of a superintendent?

"Ans. To ordain superintendents, elders, and deacons; to preside as a moderator in our conferences; to fix the appointments of the preachers for the several circuits, and, in the intervals of the conference, to change, receive, or suspend preachers, as necessity may require; and to receive appeals from the preachers and people, and decide them.

1 Robert Emory's " History of the Discipline," p. 25. 
"Ques. 27. To whom is the superintendent amenable for his conduct?

"Ans. To the conference, who have power to expel him for improper, conduct if they see it necessary.

"Ques. 28. If the superintendent ceases from traveling at large among the people, shall he still exercise his office in any degree?

"Ans. If he ceases from traveling without the consent of the conference he shall not thereafter exercise any ministerial function whatsoever in our church.

"Ques. 29. If by death, expulsion, or otherwise, there be no superintendent remaining in our church, what shall we do?

"Ans. The conference shall elect a superintendent, and the elders, or any three of them, shall ordain him according to. our liturgy.

"Ques. 30. What is the office of an elder?

"Ans. To administer the sacraments of baptism and the Lord's Supper, and to perform all the other rites prescribed by our liturgy.

"Ques. 3 I. What is the office of a deacon?

"Ans. To baptize in the absence of an elder, to assist the elder in the administration of the Lord's Supper, to marry, bury the dead, and read the Liturgy to the people as prescribed, except what relates to the administration of the Lord's Supper."

"N.B. to Ques. 33. No helper, or even deacon, shall, on any pretense, at any time whatsoever, administer the Lord's Supper."

"Ques. 35. How are we to proceed with those elders or deacons who cease from traveling?

"Ans. Unless they have the permission of the conference, declared under the hand of a superintendent, they are on no account to exercise any of the peculiar functions 
of those offices among us. And if they do they are to be expelled immediately.

"Ques. 36. What method shall we take to prevent improper persons from preaching among us as traveling preachers?

"Ans. Let no person be employed as a traveling preacher unless his name be printed in the minutes of the conference preceding, or a certificate be given him under the hand of one or other of the superintendents, or, in their absence, of three assistants, as is hereafter provided. And for this purpose let the minutes of the conference be always printed."

The answer to question 42 comprised an elaborate plan to " extirpate the abomination of slavery." It required each member, within twelve months after notice given to him by the assistants (which notice the assistants were required to give immediately), to execute legally and record an instrument "setting free every slave between the ages of forty and forty-five immediately, or at the furthest when they reach the age of forty-five; every slave between twenty-five and forty immediately, or at the furthest at the expiration of five years ; and every one between the ages of twenty and twenty-five immediately, or at the furthest when they arrive at the age of thirty; and every slave under the age of twenty as soon as they arrive at the age of twenty-five": and it also ordered that every infant, born after the afore-mentioned rules are complied with, should immediately be emancipated.

Assistants were required to keep a journal containing names and ages of all slaves, and the dates of instruments of manumission, with the name of the court book and folio in which these were recorded, "which journal shall be handed down in each circuit to the succeeding assistants." 
This plan further provided that, as these rules formed a new term of communion, all who would not conform should have liberty quietly to withdraw within twelve months after the notice; but if they neither complied nor withdrew they were to be excluded; and any member who withdrew voluntarily or was excluded should never partake of the Supper of the Lord until he obeyed. Nor should any slave-holder be admitted into the Society or to the Lord's Supper until he had complied with these rules.

Two remarkable postscripts, however, were added:

"N.B. These rules are to affect the members of our Suciety no further than as they are consistent with the laws of the States in which they reside.

"And, respecting our brethren in Virginia that are concerned, and after due consideration of their peculiar circumstances, we allow them two years from the notice given, to consider the expedience of compliance or non-compliance with these rules."

"Ques. 43. What shall be done with those who buy or sell slaves, or give them away?

"Ans. They are immediately to be expelled, unless they buy them on purpose to free them."

"Ques. 45. Is there any direction to be given concerning the administration of baptism?

"Ans. Let every adult person, and the parents of every child to be baptized, have their choice either of immersion or sprinkling, and let the elder or deacon conduct himself accordingly."

"Ques. 65. What shall we do with those members of our Society who willfully and repeatedly neglect to meet their class?

"Ans. (I) Let the assistant or one of his helpers visit them, wherever it is practicable, and explain to them the consequence if they continue to neglect, namely, exclusion. 
(2) If they do not amend let the assistant exclude them in the Society, informing it that they are laid aside for a breach of our rules of Discipline, and not for immoral conduct."

These were the principal provisions added to the minutes to adapt them to the enlarged work of a church as distinguished from a society, and to the situation in the United States.

It should be observed that the new church was established on a liturgical basis. "The Sunday Service of the Methodists in North America," sent over by Wesley, was adopted by the conference which formed the church, and ordered to be read. It included a form of public prayer, the form and manner of making and ordaining superintendents and elders and deacons, and the twenty-four Articles of Religion. In pursuance of this order, the liturgy was used in the principal churches in city and country, and gowns and bands were used by superintendents and elders.

Methodists who had been reared in the Church of England were inclined to the use of the Prayer-book, but a large majority of the members, consisting of those who had had no education in liturgical forms, exhibited dislike for them. "For some time," says Lee, " the preachers generally read prayers on the Lord's day, and in some cases the preachers read part of the morning service on Wednesdays and Fridays; but some who had been long accustomed to pray extempore were unwilling to adopt this new plan, being fully satisfied that they could pray better and with more devotion while their eyes were shut than they could with their eyes open. After a few years the Prayer-book was laid aside, and has never been used since in public worship." 1

1 Lee's " History of the Methodists," p. 107. 
Extra services on the Sabbath, especially love-feasts, frequently consumed time needed for the liturgy, so that it gradually fell into disuse. Wesley's Sunday service, though mentioned occasionally in successive Disciplines until I 792, is not officially referred to after that date. 1

He reduced the Thirty-nine Articles of the Church of England to twenty-four, and this concerning the rulers of the United States of America was added by the Christmas conference: "The President, the Congress, the General Assemblies, the Governors, and the Councils of State, as the Delegates of the People, are the Rulers of the United States of America, according to the division of power made to them by the Constitution of the United States, and by the Constitutions of their respective States. And the said States are a sovereign and independent Nation, and ought not to be subject to any foreign jurisdiction."

Wesley omitted the $3 \mathrm{~d}, 8 \mathrm{th}, \mathrm{I} 3 \mathrm{th}, \mathrm{I} 5 \mathrm{th}, \mathrm{I} 7 \mathrm{th}$, I 8 th, 20 th, 2 Ist, 23d, 26th, 29th, 33d, 34th, and 37 th articles of the Church of England. Some of the others were merely changed in phraseology or in unimportant points, but others to such an extent as to convey a meaning radically different ; for instance, in the 12 th article justification is substituted for baptism. Bishop Harris observes: "By these omissions and changes all traces of Calvinism, Romanism, and ritualism were eliminated. The Articles of Religion are therefore specially and strictly Arminian in all points which distinguish evangelical Arminianism from Calvinism." 2 It has often been reinarked that they contain no statement of the doctrines which Wesley emphasized, notably that of the witness of the Spirit and that of Christian perfection. The American Methodists, however, from the beginning, expressly adopted the "Minutes" and

1 Emory's “" History of the Discipline," p. 8o.

2 "People's Cyclopedia," "Methodism" (Hunt \& Eaton). 
Wesley's "Notes on the New Testament" as standards, and repeatedly acknowledged them during the lifetime of Wesley and on all suitable occasions since his death.

Freeborn Garrettson and James O. Cromwell were ordained as missionaries to Nova Scotia, and Jeremiah Lambert was ordained for Antigua, in the West Indies.

The organization of the church met with universal approval among Methodists, and was regarded favorably by the general public, although some communicants of the English church withdrew their sympathy and attendance, and "Jarratt could not sacrifice his churchly prejudices for the new and providential order of things."

During the conference Coke preached every day at noon, and some of the other preachers morning and evening. 


\section{CHAPTER X.}

FROM THE ORDINATION OF ASBURY TO THE DEATH OF WESLEY.

THE first Sunday after the adjournment of the conference Asbury read prayers, preached, baptized children, and ordained Henry Willis deacon, and two days later elder. Asbury writes: "Nothing could have better pleased our old church folks than the late step we have taken in administering the ordinances. To the catholic Presbyterians it also gives satisfaction, but the Baptists are discontented." This entry relates to members of those bodies who had affiliated with the Methodists. So long as the Methodists did not administer the ordinances, neither the mode nor the subjects of baptism was a living question.

Asbury pursued his journey to Charleston, S. C., where on Sunday, the $27_{\text {th }}$ of February, I 785 , he heard Jesse Lee preach the first Methodist sermon delivered in that place with the view of establishing regular preaching. So hopeful was the aspect of affairs that Willis was stationed there, and soon formed a society.

Coke traveled incessantly. At Abingdon, Md., he gave orders that the materials for the erection of the college which the late conference had decided to establish at that place be procured at once. He spent ten days in Philadelphia, and in New York three weeks, preaching, superintending the 
publication of his sermons, and collecting money for the new missions in Nova Scotia. Later he traversed Delaware. In Baltimore he induced the people to subscribe five hundred pounds sterling to build a new church. Having a considerable private fortune, he was able to relieve the needy and to assist enterprises which he established or desired to promote. His liberality, however, surpassed his available means, and his "Journal" states that when he arrived at Portsmouth, Va., on the I $5^{\text {th }}$ of March, he had less than a dollar.

At Kingston, N. C., Asbury was entertained by the governor of the State; here he met Coke and held a conference. The Rev. Devereux Jarratt owned twenty-four negroes, and was much exercised by the rule against slavery. In fact, all through Virginia disputes arose over this rule. Coke and a certain colonel had a discussion upon the topic, and the latter uttered threats against the preachers. James O'Kelly on the next day delivered a powerful speech, which made the people very angry.

Coke's account of this incident is graphic. While he was preaching against slave-holding several retired to combine to flog him. Asbury congratulates himself that "they came off with whole bones."

In another place a mob came with staves and clubs to meet him. Many of the members of the Society, however, emancipated their slaves; one fifteen, and another twentyone. Coke remarks: "These are great sacrifices, for the slaves are worth, I suppose, upon an average, thirty or forty pounds sterling each, perhaps more." When he reached North Carolina he said, "I am now done with my testimony for a time, the laws of this State forbidding any to emancipate the negroes."

To each preacher was given a petition, for his own and other signatures, entreating the General Assembly of Vir- 
ginia to pass a law for the immediate or gradual emancipation of the slaves. Coke and Asbury, by appointment, waited on General Washington at Mount Vernon. Coke thus describes the visit: "He received us very politely, and was very open to access. $\mathrm{He}$ is quite the plain country gentleman. After dinner we desired a private interview, and opened to him the grand business on which we came, presenting to him our petition for the emancipation of the negroes, and entreating his signature, if the eminence of his station did not render it inexpedient for him to sign any petition. He informed us that he was of our sentiments, and had signified his thoughts on the subject to most of the great men of the State; that he did not think it proper to sign the petition, but if the Assembly took it into consideration would signify his sentiments to the Assembly by a letter. He asked us to spend the evening and lodge at his house, but our engagements at Annapolis the following day would not admit of it." 1

The conference assembled in Baltimore on June ist. Coke preached at noon on "Ministerial Faithfulness," and, as he was to sail for Europe the next day, they sat till midnight. Early the next morning he delivered a farewell discourse on "St. Paul's Awful Exhortation to the Elders of the Church at Ephesus."

Asbury, the next Sunday after adjournment of the conference, preached a sermon at Abingdon on the occasion of the laying of the corner-stone of Cokesbury College, after which he resumed his journeys, but was for several months extremely ill. In part because of his health, and in large part because they thought the dignity of a bishop required it, his friends induced him to purchase a carriage ; but he thought it ostentatious, and bought a "secondhand sulky," leaving the carriage to be sold.

1 "Coke's Journal," p. 45. 
In England Coke met with an unpleasant reception from Wesley. Charles Wesley had charged him with speaking evil of the constitution of his country, and with misrepresenting the sentiments of John and Charles Wesley, and he acknowledged that in one of his sermons in Baltimore he had used imprudently severe language. John Wesley was entirely satisfied, and said to his brother, "I believe Dr. Coke is as free from ambition as from covetousness, and has done nothing wrongly that I know, but he has spoken wrongly, which he retracted the moment I spoke to him about it. If you cannot or will not help me yourself, do not hinder those who can and will."

Coke sailed for Nova Scotia on the 24th of September, I 786, accompanied by three preachers whom Wesley had commissioned to reinforce Garrettson and his colleagues. The voyage was of unparalleled severity; they were blown hundreds of miles out of their course, and landed on the island of Antigua, in the West Indies, remaining there until February IO, I 787 . On that date Coke sailed for Charleston, S. C., where he met Asbury, and dedicated the new Methodist chapel, which accommodated fifteen hundred. In this they held the first conference ever convened in South Carolina. The church had but forty white members, yet they had built an edifice worth a thousand pounds sterling. The conference ended, Asbury and Coke rode on horseback at the rate of three hundred miles a week, preaching every day. In regions where Coke had been persecuted for his antislavery sentiments he was received in peace, some of his most violent opponents having become members of the Society.

The conferences held in I 786 showed nearly 20,000 members and I 7 ministers. There were about 60 chapels, but the congregations were often far beyond their capacity. Huge barns were thrown open for the preachers, but even 
those would not accommodate the multitudes. It has been estimated that there were then more than 200,000 habitual attendants upon Methodist worship.

In Mecklenburg County, Virginia, Coke preached to about four thousand, which he describes as the largest congregation he had seen in America, "though there was no town within a great many miles."

A conference had been appointed for Abingdon, Md., July 24th. But to accommodate Coke its place and date had been changed, and on the Ist of May it assembled at Baltimore, where took place an extraordinary discussion, indicating the independence of the early ministers of the church, and their opposition to the exercise of doubtful or illegal episcopal power. Coke was complained of by the preachers "because he had taken upon himself a right which they never gave him, of altering the time and place of holding our conference, after it had been settled and fixed on at the previous conference." 1 Another complaint was also brought against him for writing to some of the preachers improper letters, calculated to stir up strife and contention. Lee states that the preachers were pretty generally united against him, that he acknowledged his faults, begged pardon, and promised not to meddle with their affairs when he was out of the United States.

Coke's version of the settlement is: "We mutually yielded and mutually submitted, and the silken cords of love and affection were tied to the horns of the altar for ever and ever." Asbury disposed of it in a single sentence: "We had some warm and close debates in conference, but all ended in love and peace."

The following certificate, witnessed by three of the preachers, reveals the gravity of the issue:

1 Lee's "History of the Methodists," p. 125. 
"I do solemnly engage by this instrument that I never will, by virtue of my office as superintendent of the Methodist Church, exercise any government whatever in said Methodist Church during my absence from the United States. And I do also engage, that I will exercise no privilege in the said church when present in the United States, except that of ordaining according to the regulations and law already existing or hereafter to be made in the said church, and that of presiding when present in conference, and, lastly, that of traveling at large. Given under my hand, the second day of May, in the year I 787 .

"Thomas CokE."

On this basis the conference agreed to overlook everything that had been done contrary to its judgment, provided the condition should be expressed in the minutes, which was done in these words:

"Ques. Who are the superintendents of our church for the United States?

"Ans. Thomas Coke (when present in the States) and Francis Asbury."

Asbury preached, organized, and administered the sacraments through Long Island, returning later to New York; and after traveling thousands of miles through the Middle and Southern States, the closing days of 1787 found him at Lancaster, Va.

The complete report of the state of the denomination at the close of the year showed I 33 ministers and 21,949 white and 3893 colored members; 35 preachers had been admitted on trial. Six conferences were appointed for the coming year.

The relations of the American Methodists to Wesley were adjusted in a way which at first was offensive to the founder of Methodism. At the Baltimore Conference it 
was proposed that Garrettson be elected and ordained as "superintendent over the societies in Nova Scotia and the West Indies." This proposition was made in compliance with the express wishes of Wesley and Coke, and was desired by most of the preachers in Nova Scotia; but the arrangement was not made. Bangs, who obtained his information direct from Garrettson, ${ }^{1}$ represents that Garrettson objected to be ordained until he should have visited the brethren in Nova Scotia for one year, that Coke was satisfied with this, and there the business ended; but, for some unexplained reason, Garrettson was appointed presiding elder on the Eastern Shore of Maryland.

Wesley had also proposed that Whatcoat should be appointed joint superintendent with Asbury, but most of the preachers declined to consent to it, on two grounds: "First, that Richard Whatcoat was not qualified to take charge of the connection; second, that they were apprehensive that if Whatcoat were ordained Wesley would likely recall Asbury, and he would return to England." 2 Coke, however, contended that when the church was formed, in 1784 , the conference had voted that "during the life of the Rev. Mr. Wesley we acknowledge ourselves his sons in the gospel, ready in matters belonging to church government to obey his commands." To this many of the members of the conference replied that they were not at the conference when that engagement was entered into, and did not consider themselves bound by it. Others affirmed that, though they were ready at that time, they did not now feel so; that "they had made the engagement of their own accord, and among themselves, and they believed they had a right to depart therefrom when they pleased, seeing it was not a contract made with Mr. Wesley, or any

1 " History of the Methodist Episcopal Church," vol. i., p. 258.

2 Lee, p. 126. 
other person, but an agreement among themselves. It was further argued that Wesley, while in England, could not tell whether a man was qualified to govern us as well as we, who were present and were to be governed. We believed, also, that if Mr. Wesley was here he would be of the same opinion with us." They then agreed to leave that statement out of the minutes, which was done.

Without doubt the conference was right in concluding that it had never engaged to submit its church officers to Wesley's judgment. These words are in the form for the " ordination of superintendents," prepared by Wesley, and recommended in the Prayer-book of I784: "After the gospel and the sermon are ended the elected person shall be presented by two elders under the superintendent, saying," etc. "This," says Bishop Emory," "indisputably proves that Wesley himself contemplated the election of our superintendents, and not that they were to be appointed by him." Asbury had refused to act in that capacity unless the preachers unanimously chose him. The letter of Wesley to Coke, produced by the latter for his justification, bears date of London, September 6, i 786 :

"DEAR Sir: I desire that you would appoint a General Conference of all our preachers in the United States, to meet at Baltimore on May I, I 787 ; and that Mr. Richard Whatcoat may be appointed superintendent with Mr. Francis Asbury."

Since Coke contended that this was an appointment, if the conference had yielded they might have been equally required by the same authority to submit to the recall of Asbury. As this did not spring from any disaffection toward Wesley, the conference wrote a long, loving letter, 


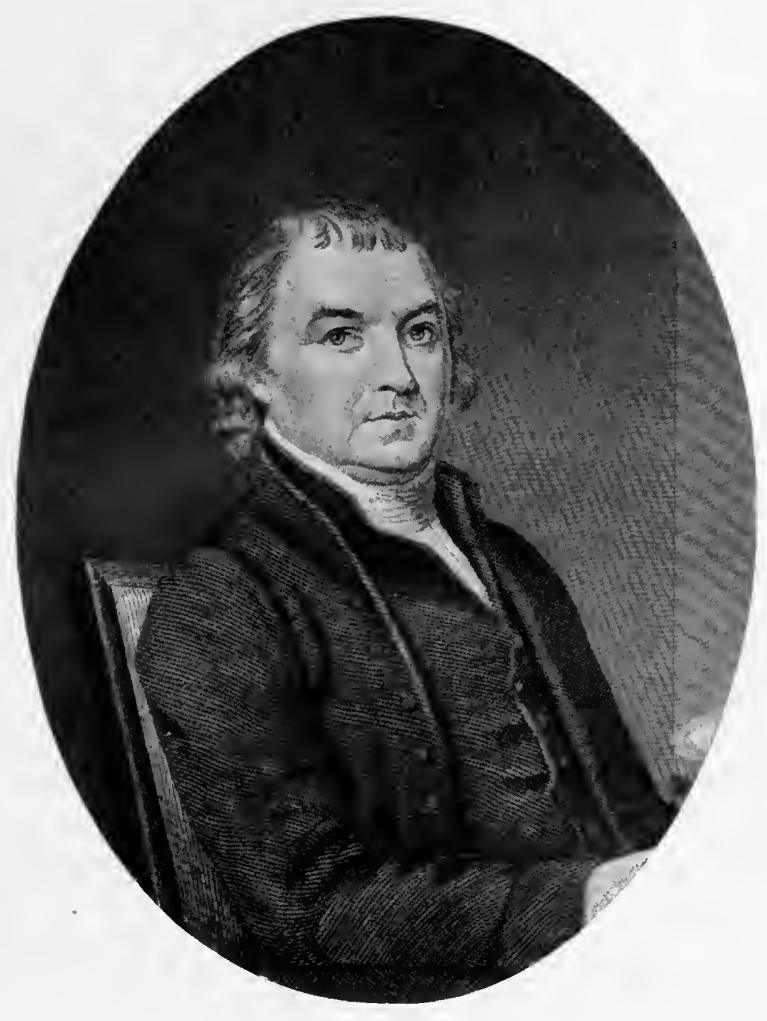

WM. MCKENDREE. 


\section{.}


requesting him to come to America and visit his spiritual children.

After traveling northwest from Georgia, over the mountains and through the primeval forest, a part of the way determining his course by compass, Asbury descended into the valley of the Mississippi, preaching and meeting the ministers as he went. He reached Uniontown, Pa., on the $22 \mathrm{~d}$ of July, and here held a conference, where the first Methodist ordination beyond the Alleghanies is supposed to have been performed. Asbury and Whatcoat, the one a bishop, the other an elder, appeared in sacerdotal robes, and the morning service was read, as abridged by Wesley. The candidate was Michael Leard, famous for being able to repeat nearly the whole of the Old Testament and large portions of the New.

Forty-eight preachers were admitted on trial in 1788 , among them William McKendree and Valentine Cook. This year the church mourned the loss by death of four ministers.

The word "superintendent" was omitted from the first question, which in the minutes for I 788 reads: "Ques. Who are the bishops of our church for the United States?" Wesley misunderstood the spirit of the change, but when it was fully explained as signifying only what he meant by the word "superintendent," and that it was adopted to agree with the term "Episcopal" in the title of the church, he defended the action against the severe criticisms of his brother Charles and others, and in every possible way expressed his regard for his American brethren.

The first conference ever held in the city of New York assembled Tuesday, September 30, I 788, and continued until the following Saturday.

Garrettson was appointed presiding elder of the districts north of the city of New York, including all the circuits from 
New Rochelle to Lake Champlain. No material alterations were made in the Discipline in this year.

Asbury was in Virginia and North Carolina in January, I 789, passing into South Carolina on the 3d of February. On the 2oth of that month he prepared his plan for the coming conference, and a special entry is significant: "I made out a registry of all the preachers on the continent who bear the name of Methodists." The conference over, Asbury left Charleston, and on the night of the 26th was joined by Coke, who had landed at Charleston about three hours after the former's departure. During Coke's absence from the United States he had been constantly engaged in England and the West Indies, and had sailed from Jamaica to Charleston. En route to Georgia they found congregations everywhere; and in that State 20I I Methodists, the increase the preceding year being 784 .

The conference agreed to erect a college in Georgia, and the leading members, spoken of by Coke as "our principal friends," engaged to purchase at least two thousand acres of good land for its support; in one congregation I 2,500 pounds of tobacco were subscribed for the purpose; this, it was estimated, would produce, clear of expenses, about one hundred pounds sterling. $\mathrm{He}$ also states that the conference most humbly entreated Wesley to permit them to name it Wesley College, as a memorial of his affection for Georgia and of its great respect for him. They then returned to Charleston.

By the 2oth of April they were holding the North Carolina Conference, at which nineteen preachers assembled, some of whom, to attend it, had crossed the Alleghany Mountains. The increase in that State had been 74I, and the whole number of members was 6779 . This conference included some of the appointments in the State of Kentucky, from which had been received a letter asking that a college 
might be erected, and offering to give or purchase three or four thousand acres of good land to support it. The conference sent word: "If they will provide five thousand acres of fertile ground, and settle it on such trustees as we shall mention, under the direction of the conference, we will undertake to build a college for that part of our connection within ten years."

Crossing into Virginia, they held the conference in Petersburg. Coke was astonished at the treatment he received in Halifax County; there they had persecuted him, and now "almost all the great people of the county came in their chariots and other carriages to hear me, and behaved with great propriety. There were not less than five colonels in the congregation."

Coke saw an illustration in Annapolis, Md., of the kind of religious excitement which so disturbed the spirit of Thomas Rankin. He was not unfavorably affected, for, referring to the current charges of fanaticism, he observes: "Whether there be 'wild-fire' in it or not, I do most ardently wish that there were such a work at this time in England." At the conference in Baltimore he preached to two thousand who remained till two o'clock in the morning in prayer and in praising God for the conversion of sinners. From that city they went to Cokesbury, and found that "God was working among the students." Asbury says: "One, however, we expelled."

At the first conference in New Jersey, though great efforts had been made to awaken the people, there had been a decrease of 795 . Coke remarks that this sometimes happens where the ministers have been most faithful.

The second conference was held in New York on the 28th of June. At the first a comprehensive plan had been formed for "the extension of the work of God along the Hudson River." Garrettson was commissioned to execute 
it, with the aid of the preachers who had offered themselves for trial. There were then no Methodist societies farther north than Westchester. He requested the young men to meet him when the conference adjourned, and directed them where to begin, and how to form their circuits; informing them that he should proceed up the North River to the extreme parts of the work, visiting towns and cities on the way, and on his return should hold their Quarterly Meetings. Immediately afterward he began a tour through the northern part of the State of New York and Vermont. At every point he met difficulties. The scattered congregations of Lutherans and Dutch Reformed on the sides of the Hudson were feeble. In Vermont and western Massachusetts, though the country was regularly divided into parishes, each of which had generally a settled pastor, the doctrines taught were Calvinistic, and experimental religion was at a low ebb. The laity were as forward as the ministry to attack the Arminians, and as soon as a Methodist preacher finished his discourse he had to encounter "a spirit of opposition as irksome to an ingenuous mind as it is unprofitable to a hardened heart." 1 Nevertheless Garrettson visited New Rochelle, North Castle, Bedford, Peekskill, and Rhinebeck, preaching everywhere. Such was his personal dignity that he commanded respect, and such his zeal that he passed through this vast district every three months, traveling about a thousand miles, and preaching upward of one hundred sermons. The reports of his success at this conference were highly encouraging.

For several years Jesse Lee had entertained the design of introducing Methodism into New England, as at Cheraw, in the South, he had met a traveling merchant from the Eastern States, whose accounts caused him to think it his duty to pioneer the denomination into that part of the

1 Bangs's "Life of Garrettson," p. 173. 
country. Asbury considered the scheme premature, if not extravagant, but Lee always adhered to it.

Charles Wesley had preached in Boston on his way from Georgia to England in 1736 , but Methodism, in the signification of the word as used in this work, had not then arisen. Boardman had also preached in New England in I 772, and some of Garrettson's preachers on the Hudson had crossed the boundary line before Lee. William Black, of Nova Scotia, in his travels to and fro had preached occasional sermons in New England, and about two years before Lee was appointed to Connecticut, Cornelius Cook had preached in Norwalk, but without permanent results. Garrettson, on his return from Nova Scotia, passing through Boston in 1787 , found three persons who had been members of Boardman's society, which, however, in the absence of pastoral supervision, had disintegrated. Garrettson preached several sermons in private houses.

Lee began a circuit at Norwalk, Conn., on the I $7^{\text {th }}$ of June, I789. No house could be procured. Every person was afraid that he might complicate himself if he gave any aid to the movement. Mr. Lee says: "I then went into the street, and began to sing, and then prayed, and preached to a decent congregation." Four days later he preached in the city of New Haven to as many as could crowd into the court-house. Being denied a private house to preach in, he asked for the use of an old deserted building, but was refused. He then proposed to preach in a neighboring orchard, but was repulsed, and finally stood under an apple-tree on the highway. He notified the people that he would return in two weeks, and if any would open their houses he would be glad, but if none were willing the meeting would be at the same place.

At Fairfield the schoolmaster and four women came to hear Lee, but as he sang the number increased to forty. In 
New Haven the president of Yale College and many of the students attended. At Danbury, one day, he preached twice at the court-house. In New Haven on his second visit the state-house bell was rung, and the people assembled; but influential men procured him the opportunity of preaching in the Congregational chapel. Among his hearers was the pastor of that church, and Dr. Edwards, son of the great Jonathan, the former president of Princeton College. When he had finished, though several told him they were much pleased with the discourse, no man invited him home. Lee says: "I went back to the tavern, retired into a room, went to prayer, and felt the Lord precious to my soul. I believed the Lord had sent me there. If so, I was sure to find favor in the eyes of some of the people. In a little time David Beacher came, asked me to go home with him, and said he would be willing to entertain me when I came to town again. I went with him, and his wife was very kind." David "Beacher" was an honest blacksmith, the father of Lyman Beecher. Had Lyman Beecher's mother not been removed by death shortly after his birth, on account of which he was adopted and brought up elsewhere, by his uncle, Lot Benton, it is not a violent stretch of imagination to fancy that the boy, then not quite sixteen years of age, might have fallen under the strangely magnetic influence of Lee, whom youths generally found irresistible.

After forming an extensive circuit in Connecticut, Lee entered Rhode Island, preaching and making appointments as he went.

The minutes of 1789 introduce a new question:

"Ques. Who are the persons that exercise episcopal office in the Methodist Church in Europe and America?

"Ans. John Wesley, Thomas Coke, Francis Asbury." 
The second also differs from any preceding question, though containing no new fact.

"Ques. Who have been elected by the unanimous suffrages of the General Conference to superintend the Methodist connection in America?

"Ans. Thomas Coke, Francis Asbury."

This conference adopted a scheme, presented by the bishops, of an institution to be known as the "Council." The ground of the action was the necessity of some method of general legislation, and the supposed impossibility of holding a General Conference. The purpose was strenuously opposed, and there was much debate; but it finally prevailed by a large majority. The Council was to be composed of the bishops and presiding elders. Nine should be required for a quorum, and should there be less than that number present the bishops were to fill vacancies by summoning such elders as they thought best. The Council should have authority to mature everything considered expedient " to preserve the general union, to make and keep an external form of worship similar in all societies, to preserve the essentials of Methodist doctrine and discipline pure and uncorrupted, to correct all abuses and disorders," and everything " necessary for the good of the church, and for promoting and improving the colleges and plan of general education." Nothing should be considered as a resolution of the Council unless assented to unanimously, and nothing so assented to should be binding in any district until it was agreed upon by a majority of the conference held for that district. The first Council was to be held at Cokesbury on the first day of December, and subsequently the bishops were to have authority to summon the Council to meet at such times and places as they judged expedient. 
Those in attendance at the first session were Asbury and eleven conspicuous elders, the most influential being O'Kelly, Dickins, and Garrettson.

After transacting much business, they resolved that " every resolution of the first Council shall be put to vote in each conference, and shall not be adopted unless it obtains a majority of the different conferences. But every resolution received by a majority of the several conferences shall be received by every member of each conference." The last resolution ordered that another Council should be convened at Baltimore on the first day of December, I 790.

In the conference that sat in New York in the year I 789, Asbury presented the following proposition: "Whether it would not be proper for us, as a church, to present a congratulatory address to General Washington, who has lately been inaugurated President of the United States, in which should be embodied our approbation of the Constitution, and professing our allegiance to the government." The conference approved and warmly recommended the measure, and appointed Coke and Asbury to draw up the paper. After consideration it was concluded that, though Coke was senior bishop, yet, not being an American citizen, it would not be proper for him to present the address. John Dickins and Thomas Morrell were delegated to wait on President Washington with a copy, and to request him to appoint a time to receive the bishops, one of whom was to read it to him and receive his answer. They did so, and as Morrell was personally acquainted with him, he was asked to submit a copy, and request Washington's reception of the original by the hands of the bishops. The President appointed the fourth succeeding day at twelve o'clock, and at the hour Bishops Coke and Asbury were present, accompanied by Dickins and Morrell. The latter, in a letter to the Rev. Ezekiel Cooper from his residence, August 26, 
1827, says that Asbury read the address in an impressive manner, the President read his reply with fluency and animation, they exchanged their respective documents, and after sitting a few minutes the visitors retired.

The following is the address of the bishops of the Methodist Episcopal Church :

\section{"To the President of the United States.}

"SIR: We, the bishops of the Methodist Episcopal Church, humbly beg leave, in the name of our Society collectively in these United States, to express to you the warm feeling of our hearts, and our sincere congratulations on your appointment to the Presidentship of these States. We are conscious, from the signal proofs you have already given, that you are a friend of mankind; and, under this established idea, place as full confidence in your wisdom and integrity for the preservation of those civil and religious liberties which have been transmitted to us by the providence of God and the glorious Revolution, as we believe ought to be reposed in man.

"We have received the most grateful satisfaction from the humble and entire dependence on the great Governor of the universe which you have repeatedly expressed, acknowledging him the source of every blessing, and particularly of the most excellent Constitution of these States, which is at present the admiration of the world, and may in future become its great exemplar for imitation; and hence we enjoy a holy expectation that you will always prove a faithful and impartial patron of genuine, vital religion, the grand end of our creation and present probationary existence. And we promise you our fervent prayers to the throne of grace, that God Almighty may endue you with all the graces and gifts of his Holy Spirit, that he may enable you to fill up your important station to his glory, 
the good of his church, the happiness and prosperity of the United States, and the welfare of mankind.

"Signed, in behalf of the Methodist Episcopal Church,

"Thomas CoKe,

"Francis ASBURy.

“ NEW YoRK, May 29, 1789."

The reply of President Washington was as follows:

"To the Bishops of the Methodist Episcopal Church in the United States of America.

"Gentlemen: I return to you individually, and through you to your Society collectively in the United States, my thanks for the demonstration of affection, and the expressions of joy offered, in their behalf, on my late appointment. It shall be my endeavor to manifest the purity of my inclinations for promoting the happiness of mankind, as well as the sincerity of my desires to contribute whatever may be in my power toward the civil and religious liberties of the American people. In pursuing this line of conduct, I hope, by the assistance of divine Providence, not altogether to disappoint the confidence which you have been pleased to repose in me.

"It always affords me satisfaction when I find a concurrence of sentiment and practice between all conscientious men, in acknowledgments of homage to the great Governor of the universe, and in professions of support to a just civil government. After mentioning that I trust the people of every denomination who demean themselves as good citizens will have occasion to be convinced that I shall always strive to prove a faithful and impartial patron of genuine, vital religion, I must assure you in particular that I take in the kindest part the promise you make of presenting your prayers at the throne of grace for me, and that I like- 
wise implore the divine benediction on yourselves and your religious community.

"GEORGE WASHINGTON." 1

A few days after the address and the response were inserted in the public papers, some of the ministers and members of other churches appeared dissatisfied that the Methodists should take the lead, and the other denominations successively followed the example. The papers took up the question of Coke's signing the address as bishop, and High-churchmen printed such inquiries as "Who is he?" "How came he to be a bishop?" "Who consecrated him?" Severe strictures were made on the impropriety of a British subject's signing a paper approving the government of the United States. They charged him with duplicity, and with being an enemy to the independence of America, and alleged that he had written an inflammatory epistle to the people of Great Britain, condemning the efforts of the Americans to obtain independence.

The minutes of 1790 show that 67 were ordained elders and 57 deacons, besides which 47 preachers were received on trial, and 57,63 I lay members added, of whom about one fourth were classified as colored ; and the whole number of preachers was 227. Fourteen conferences were held in Charleston, S. C., Georgia, Kentucky, Holston, Tenn., North Carolina, others in Virginia, Maryland, Pennsylvania, New Jersey, and the last for the year in the city of New York on the 4th of October. Twenty new circuits and stations were formed, and among them were three in the South, six in the West, three in Connecticut-New Haven, Hartford, and Litchfield-and one in Massachusetts, at Boston.

The first sermon preached by the Methodists in the city 1 Bangs's " History of Methodism," vol. i., p. 284 . 
of Middletown was on the seventh day of December, I 789 , and the first in Wilbraham, Mass., May $3 \mathrm{~d}$ of the same year. The introduction of Methodism into Boston and vicinity is described by Jesse Lee, who has the undisputed honor of its permanent establishment. He observes: "In the course of the preceding summer Mr. Freeborn Garrettson had visited that town [Boston] and preached. I made them a visit in July. On one occasion I went out on the Common, and, standing on a table, began to sing with only a few persons present. But, having prayed and begun to preach, the number increased so that there were two or three thousand attentive hearers. The number was still more greatly increased the next Sabbath day at the same place at six o'clock in the afternoon."

Lee furnishes interesting details of the opening of the work. The first Methodist sermon in Salem was preached July I 2, I 790, in Newburyport three days later, in Danvers

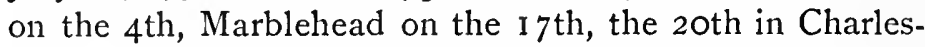
town. On the I 4 th of December the first sermon in Lynn was preached. Notwithstanding the multitude to whom Lee preached on the Common in Boston, he found it hard to procure a place for service, and "the Word took but little hold on the minds of the hearers," whereas in Lynn as soon as he began he produced a powerful effect on the hearers, who flocked to hear by hundreds. Therefore it soon appeared that Lynn was the place that should be attended to in preference to any other.

Some time after Lee had begun his work in New England, Garrettson, accompanied by the famous Black Harry, entered Connecticut at Sharon, and preached under the trees to a thousand people. At Litchfield he was permitted to preach in the Episcopal church and in the Presbyterian meeting-house. But after two or three days he reached the interior of New England, and found himself surrounded 
by the flames of doctrinal discussion, which Lee and his colleagues had aroused. At Worcester he went from one end of the town to the other, and could get no one to open the court-house and gather the inhabitants. The next day he rode forty-eight miles to Boston. His "Journal " contains a passage showing the state of things in that city with regard to negroes: "I boarded Harry with the master mason for the Africans, and I took my own lodgings with a gentleman who had been a Methodist in England, but had, I fear, fallen from the spirit of Methodism." Before leaving that part of the country he preached in Providence, where he was well received by the churches, by Christians in particular, and by a venerable pastor named Snow. But in Hartford he was mobbed. In his first sermon he encountered " as ill-behaved an audience as I have ever seen in New England, and the next night some of what are called 'the gentry' behaved so ill that I was under the necessity of breaking up the meeting, declining to preach by candle-light "; but he preached the next day in the state-house. ${ }^{1}$

Thomas Ware, who had been traveling in Tennessee, was taken by Bishop Asbury to North Carolina in the spring of I789. Everywhere Ware, by his wisdom, eloquence, and piety, commanded respect and won adherents to his cause and friends to himself.

The conversion of General Bryan, a lawyer of distinction, and a professed deist, produced in a day an effect which could hardly have been compassed in a year of ordinary religious work. At the Quarterly Meeting in I790, to which he had been drawn by the persuasions of his wife, the preaching, with occasional intervals, continued for several hours. "The whole assembly were from time to time bowed down like the slender reed before the passing breeze; but none of them had as yet lost their elasticity. Many 
hearts seemed bruised, but none broken. The last that spoke melted his auditors on these affecting words: "Which none of the princes of this world knew : for had they known it, they would not have crucified the Lord of glory.' " Under this discourse General Bryan wept, and many wondered to see him volunteer in taking the collection, at the close of which, after asking the privilege of addressing the people, he spoke in the following strain:

"FELLOW-CITIZENS: I have sometimes trembled before the majesty of courts. But where am I now? and what? An advocate? Yes! Before a judge weak and erring like myself? No, but before the Judge eternal! To plead the cause of truth against myself, and against many of you, who, like myself, have crucified the Lord of glory! Had I known it, I would not have done so wickedly, nor would you, nor you [pointing to two of his deistical fraternity]. You see my tears; they are tears of penitential grief for myself and for you; for we have denied the Lord that bought us with his own blood.

"Ye dear heralds of the gospel! I am an advocate for Christ. You have convinced me. You say, when the Eternal would save the world he chose a way known only to himself. None of the princes of this world knew it, and they could not until it was told them, and then they would not believe! So neither would I until you melted me into the belief. Some may doubt it, but I know God has sent you, and your God and people shall be mine."

"During this speech," adds Ware, "the people were silent as death, save now and then a sob or shriek; but now a loud cry arose, and continued with many until the going down of the sun; and the slain of the Lord were many." 1

1 "Memoir of Thomas Ware," pp. 166, 167. 
A rule is found in the minutes of 1790 , establishing Sunday-schools :

"Ques. What can be done in order to instruct poor children (white and black) to read?

"Ans. Let us labor, as the heart and soul of one man, to establish Sunday-schools in or near the place of public worship."

The rule provided that the teachers should be appointed by bishops, elders, deacons, or preachers, that they must teach gratuitously, and that the school should open at six in the morning, and continue till ten, and at two in the afternoon, and continue till six, "where it does not interfere with the public worship." The Council was also instructed to "compile a proper school-book to teach them learning and piety." As the schools were established in several places, and the greater part of the scholars were "black children whose parents were backward about sending them," ${ }^{1}$ the masters became discouraged, and, having no pay and little promise of doing good, the work in this form was soon suspended. So far as can be ascertained, the first of the kind in the New World was established by Francis Asbury, in I 786, at the house of Thomas Crenshaw, in Hanover County, Virginia, and the first recognition of Sunday-schools by an American church was given by this vote in the Conference of 1790 .

The increase of members in I790, though great, was partly owing to a difference in the time of taking the accounts. Says Lee: "Last year it was closed in May. This year in October, which extended the time to one year and five months. Had the numbers been taken in May, as they were the last year, the increase would not have been so large; but there was a most blessed work of God in different parts of the country." 2

I Lee's " History of the Methodists," p. 163.

2 Ibid. 
The name of John Dickins, who had been stationed at Philadelphia in I 789, his appellation being " book steward," a term in use among the Wesleyans in England, appears by itself in the minutes of 1790 , under the designation of "superintendent of the printing and book business." In I 789 Philip Cox also was left without a circuit, as "book steward at large."

The second Council convened on December I, I 790, and, after having considered thirty-one subjects, adjourned, to meet in two years.

Coke, after traveling through Great Britain and Ireland, and making a visit to the West Indies, accompanied by Hackett, one of his missionaries, had sailed from Jamaica to the United States, and arrived at Charleston, February 23, I 791. As he was known to be on the way, the conference then in session expected him; and as the members had remained one day longer than their business required, hoping for his arrival although the vessel was wrecked, they had the privilege of meeting, and Coke records his pleasure at spending the day with them "in many solemn and useful conversations."

Coke and Asbury took separate routes to the Georgia Conference, and after it adjourned proceeded to the North Carolina Conference, continuing together till they arrived at Port Royal, where, on the 29th of April, they received intelligence of the death of John Wesley, which had occurred March 2, I79I.

At one period it might have been important to present a catalogue of Wesley's literary works, to furnish evidence of his scholastic attainments, to defend him from the charges of enemies, to demonstrate the extent of his influence; but his fame may be trusted safely to Macaulay, Lecky, Green, and every modern church historian of rank, who have placed him upon a pedestal apart, agreeing with one 


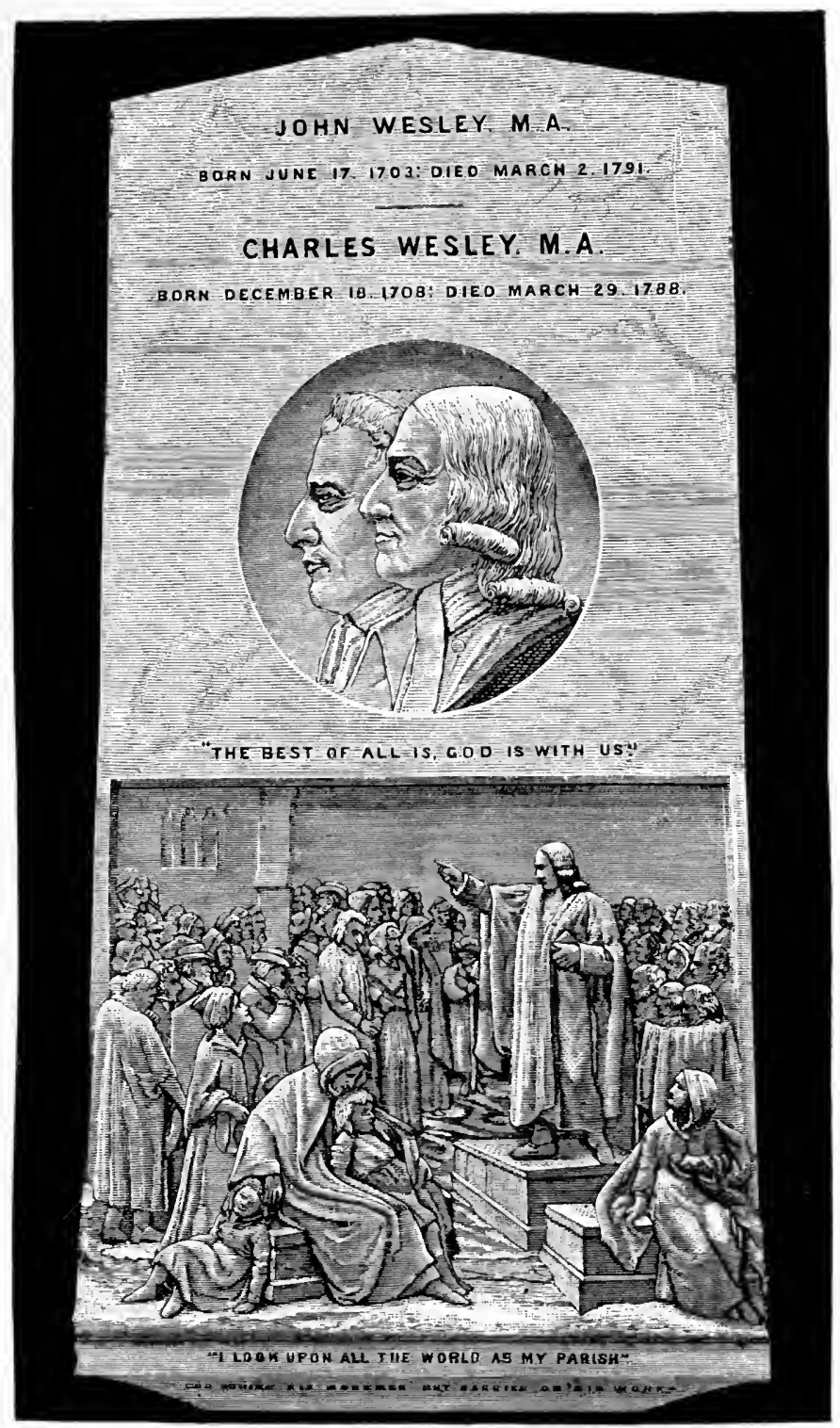

MEMORIAL TABLET IN WESTMINSTER ABBEY. 
of the most recent of them, Dr. Philip Schaff, that he was "the most apostolic man since the apostolic age."

A remarkable testimonial to him, in view of the fact that Wesley's least partial biographer is Southey, is found in a letter written by the latter to Wilberforce, in which he says: "He was the most influential mind of the century-the man who will have produced the greatest effects centuries, or perhaps millenniums, hence, if the present race of men should continue so long." 1

Wesley sympathized with every movement having in view the welfare of the human race. The last letter he ever wrote was addressed to Wilberforce, who had brought before the Parliament the question of the abolition of slavery. It bears date of London, February 24, I 79I, and shows that age had not diminished the vigor of his style.

"My DEAR SIR: Unless the Divine Power has raised you up to be as Athanasius, contra mundum, I see not how you can get through your glorious enterprise in opposing that execrable villainy which is the scandal of religion, of England, and of human nature. Unless God has raised you up for this very thing, you will be worn out by the opposition of men and devils; but if God be for you, who can be against you?"

Wesley exerted a powerful influence over John Howard, the philanthropist, and says of him: "I had the pleasure of a conversation with Mr. Howard, I think one of the greatest men in Europe. Nothing but the mighty power of God can enable him to go through his difficult and dangerous employments."

Howard, writing to Alexander Knox, Esq., refers to Wesley in these words: "I was encouraged by him to go

1 " Wilberforce Correspondence," vol. ii., p. $3^{88 .}$ 
on vigorously with my own designs. I saw in him how much a single man might achieve by zeal and perseverance, and $I$ thought, Why may not I do as much in my way as Mr. Wesley has done in his, if I am only as assiduous and persevering? and I determined I would pursue my work with more alacrity than ever."

One quality of John Wesley was that of never forgetting a friend, and always manifesting his friendship when that friend was in need. In England was a barber named William Shent, who in old age fell into sin and embarrassment. His friends forsook him. Whereupon Wesley wrote to the Methodist Society a letter which illustrates his intensity, frankness, irresistible logic, eloquence, and pathos:

"London, January II, 1779.

"I have a few questions which I desire may be proposed to the Society at Keighley:

"Who was the occasion of the Methodist preacher's first setting foot in Leeds? William Shent.

"Who received John Nelson into his house at his first coming thither? William Shent.

"Who was it that invited me, and received me when I came? William Shent.

"Who was it that stood by me while I preached in the street, with stones flying on every side? William Shent.

"Who was it that bore the storm of persecution for the whole town, and stemmed it at the peril of his life? William Shent.

"Whose word did God bless for many years in an eminent manner? William Shent's.

"By whom were many children now in Paradise begotten in the Lord, and many now alive? William Shent.

"Who is he that is ready now to be broken up and turned into the street? William Shent. 
"And does nobody care for this? William Shent fell into sin and was publicly expelled the Society; but must he be also starved? Must he, with his gray hairs and all his children, be without a place to lay his head? Can you suffer this? Oh, tell it not in Gath! Where is gratitude? Where is compassion? Where is Christianity? Where is humanity? Where is concern for the cause of God? Who is a wise man among you? Who is concerned for the gospel? Who has put on bowels of mercy? Let him arise and exert himself in this matter. You here all arise as one man and roll away the reproach. Let us set him on his feet once more. It may save both him and his family. But what we do, let it be done quickly.

"I am, dear brethren, your affectionate brother, "JOHN WESLEY."

Wesley's fame as a preacher was somewhat obscured by the extraordinary power of Whitefield, whose dramatic eloquence attracted all classes. Yet the severity and overwhelming religious power of Wesley were such that men who would not submit to the claims of God as expounded by him did not dare to hear him. He attracted even larger congregations than Whitefield, and produced a more powerful and permanent impression: Rigg, in "The Living Wesley," compares the two justly: "Wesley was not a pictorial or dramatic preacher like his great preaching contemporary, Whitefield; but whereas Whitefield, powerful preacher as he was, was yet more popular than powerful, Wesley, popular preacher as he was, was yet more powerful, in comparison with his fellows, than he was popular."

No preacher since the days when Paul reasoned of righteousness, temperance, and judgment to come, equaled him, on extraordinary occasions, in moral power, of which many instances are given by Southey. 
A striking description, because of the man who wrote it and the fact that he did so with no thought of publication, is in a letter written to Wesley by John Whitelamb, who was Samuel Wesley's amanuensis. He had been a fellow-student of Wesley's at Oxford, and interested in Methodism before it took on its permanent type. He had married Wesley's sister Mary, but she died in I 735. Afterward he became a rector in the Church of England, and did not sympathize with Methodism; but hearing Wesley preach at Epworth, standing on his father's tombstone, subsequently wrote him the following letter:

"DEAR BRother: I saw you at Epworth on Tuesday evening. Fain would I have spoken to you, but that I am quite at a loss how to address you or behave. Your way of thinking is so extraordinary that your presence creates an awe, as though you were an inhabitant of another world. God grant that you and your followers may have entire liberty of conscience; will you not allow others the same? I cannot think as you do; but I retain the highest veneration and affection for you. The sight of you moves me strangely. My heart overflows with gratitude. I cannot refrain from tears when I think, This is the man who at Oxford was more than a father to me! This is he whom I have there heard expound or dispute publicly, and preach at St. Mary's with such applause!"1

Later their former intimacy was in some degree renewed, for in 1742 Wesley preached in Mr. Whitelamb's church morning and afternoon at the latter's request; and at six in the evening, having already delivered three sermons, he preached in Epworth churchyard for nearly three

1 "Methodist Magazine," I778, edited by John Wesley (London). 
hours, the people constraining him to remain and lead them to Christ.

The same awe-inspiring influence and overwhelming personal force characterized him sometimes even in dealing with his brother Charles, who on one occasion attempted to dissuade him from doing what he thought (perhaps mistakenly) his duty. In answer he exclaimed, "Brother, when I devoted to God my ease, my time, my life, did I except my reputation? No."

So far as is known, the last letter from Wesley to the United States was written only twenty-nine days before his death, to the Rev. Ezekiel Cooper:

"Near London, February I, I79I.

"My DEAR Brother: Those that desire to write or say anything to me have no time to lose; for time has shaken me by the hand, and death is not far behind. But I have reason to be thankful for the time that is past; I felt few of the infirmities of age for fourscore and six years. It was not till a year and a half ago that my strength and my sight failed. And still I am enabled to scrawl a little and to creep, though I cannot run. Probably I should not be able to do so much did not many of you assist me by your prayers. I have given a distinct account of the work of God which has been wrought in Britain and Ireland for more than half a century. We want some of you to give us a connected relation of what our Lord has been doing in America, from the time that Richard Boardman accepted the invitation and left his country to serve you. See that you never give place to one thought of separating from your brethren in Europe. Lose no opportunity of declaring to all men that the Methodists are one people in all the world, and that it is their full determination so to continue: 
Though mountains rise, and oceans roll, To sever us in vain.

To the care of our common Lord I commit you; and am

"Your affectionate friend and brother, "John Wesley."

Probably the best estimate of Wesley's character and career is in "Asbury's Journal," under date of Friday, April 29, I79I :

"The solemn news reached my ears that the public papers had announced the death of that dear man of God, John Wesley, who died in his own house in London in the eighty-eighth year of his age, after preaching the gospel sixty-four years. When we consider his plain and nervous writings, his uncommon talent for sermonizing and journalizing; that he had such a steady flow of animal spirits, so much of the spirit of government in him; his knowledge as an observer, his attainments as a scholar, his experience as a Christian-I conclude, his equal is not to be found among all the sons he hath brought up, nor his superior among all the sons of Adam he may have left behind."

The great length of John Wesley's life was of incalculable advantage to Methodism and to spiritual Christianity; for it perpetuated the organization, and admitted of all possible experiments, the rejection of failures, and the improvement of methods worthy of permanent adoption. This was done under an autocratic authority inspired by one desire, the promotion of Christ's kingdom ; an authority which lost no influence by confessions of error or change, and was superior to opposition by reason of his financial grasp upon the property of the connection and his control of appointments.

Except that which would arise on the death of the 



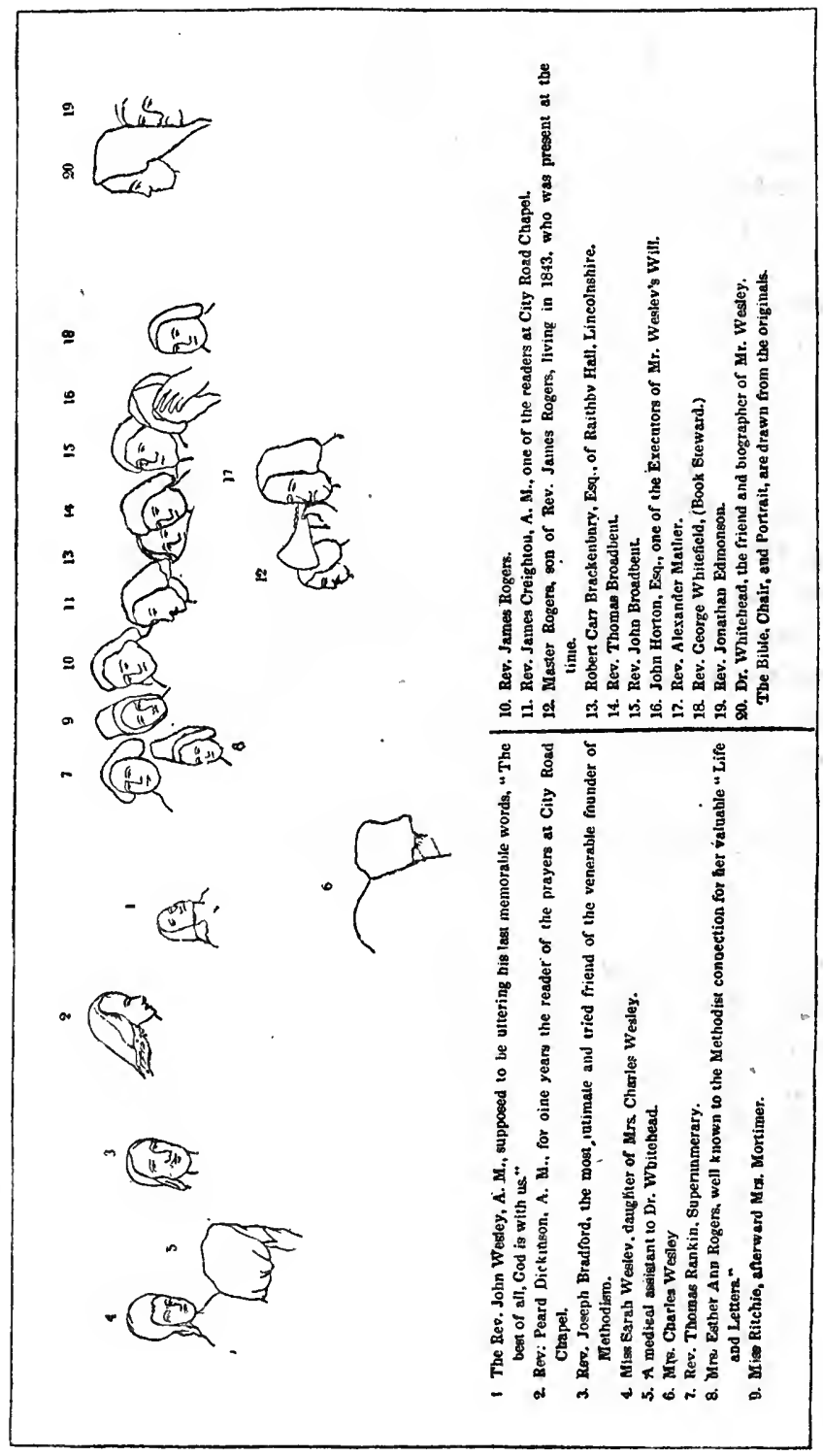




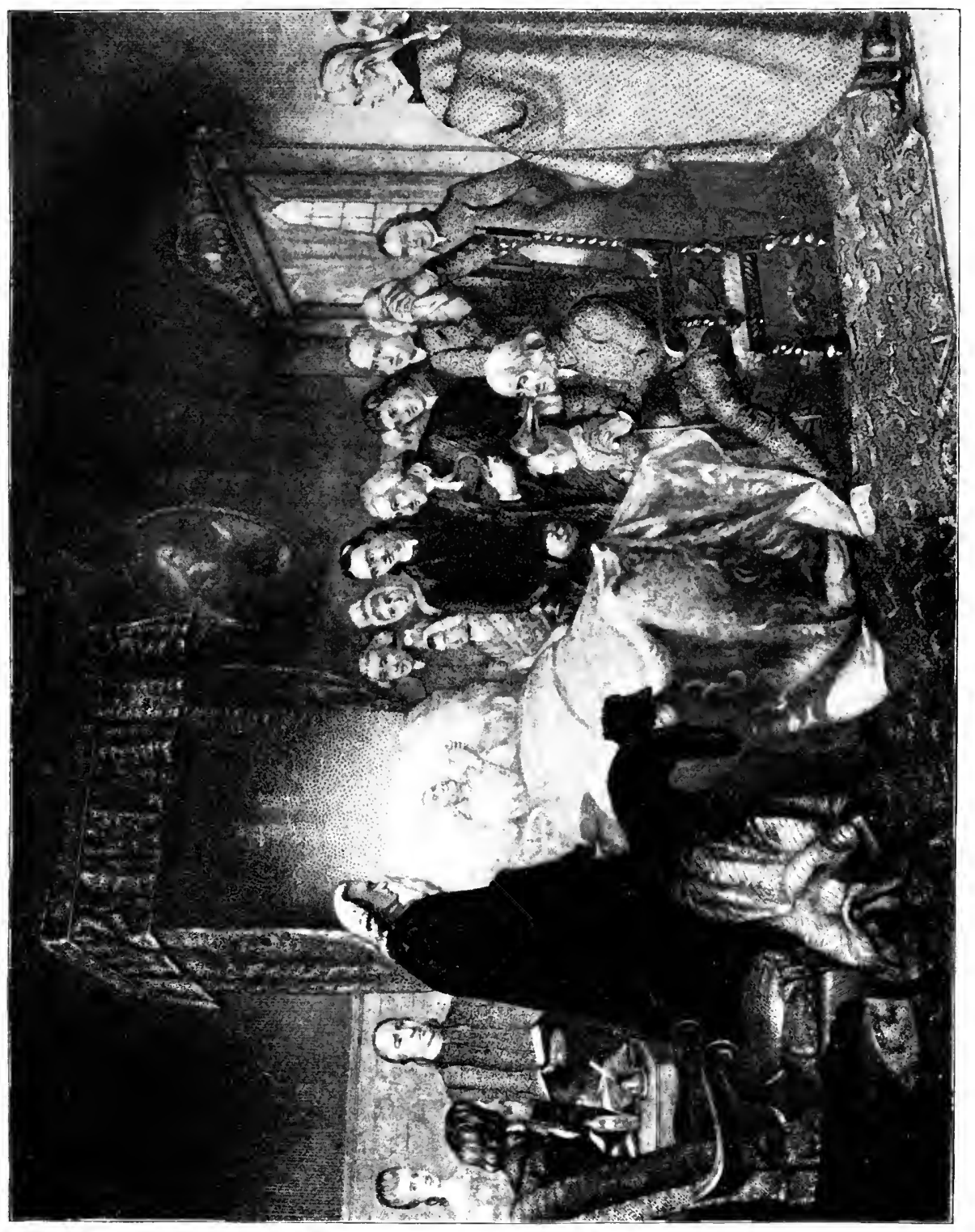

至 

founder, all crises in the movement had been met and successfully passed; and the best preparation of which he was capable, with the aid of trusted personal and legal counsel, had been made by the passage of an act of Parliament constituting and perpetuating a body which should hold the property, maintain the institutions, the doctrines, and the conference, and periodically distribute the ministers when the ruler of Methodism should be no more.

The honors showered upon him during his old age contributed much to the preservation and increase of the respect shown to Methodism, and to its general recognition as an important factor in modern civilization. When, after having long been spoken of by men chary of compliments and unsympathetic with religious enthusiasm as "the noblest old man in England," it was announced that he had gone hence forever, the controversies which had accompanied his earlier career, and had been revived and intensified by his ordination of Coke and Whatcoat and the establishment of an independent church in the United States, subsided; and all who wrote or spoke of him, except incorrigible bigots, found it easy to say nothing but good of the dead. Irritation caused by Wesley's interference in the affairs of this country had already passed away, and to be a "follower of Wesley" was no longer a sign of contention.

Although disturbances arose among the Methodists of England, the parliamentary deed which secured the property, and the Legal Hundred who held the power, maintained the body intact. Those controversies did not affect Methodism in this country.

Not less than the long life of Wesley and the fact of his death did the manner of his departure contribute to the religious growth of his own people, and of all who were favorably affected toward him. On the $25^{\text {th }}$ of February 
he grew very ill; but on the 27 th seemed better, and repeated one of his brother's hymns:

\section{Till glad I lay this body down, \\ Thy service, Lord, attend; \\ And oh, my life of mercy crown \\ With a triumphant end!}

On the next day he repeated to himself, "There is no way into the holiest but by the blood of Jesus." On the morning of March Ist he asked for a pen, but was unable to write. A friend offered to write for him, and said, "Tell me what you wish to say." "Nothing," he replied, "but that God is with us," and began to sing, "I'll praise my Maker while I've breath." He made some remarks about what should be done after his death, took each one by the hand, and said, "Farewell! farewell!" $\mathrm{He}$ asked that his sermon on "The Love of God to Fallen Men" " might be scattered abroad and given to everybody." His last word was "Farewell," and without a groan or sigh he was gone. The account of the closing scenes, which took place in the presence of eleven ${ }^{1}$ friends, including his physician, filled Methodists throughout the world with praise; and since that day multitudes have approached death with confidence, inspired by the recollection of the manner of his departure and a personal experience of his declaration, "The best of all is, God is with us." Of John Wesley more than of any other minister of the gospel since the death of St. Johnwith the possible exception of Martin Luther-it may be said assuredly, "He, being dead, yet speaketh."

1 "It is not possible to ascertain who and how many of Wesley's friends were present at the moment of Wesley's death. Tyerman gives the number as eleven and names them in his description of the scene. Yet all those shown in the illustration were with him during some part of his last hours." 


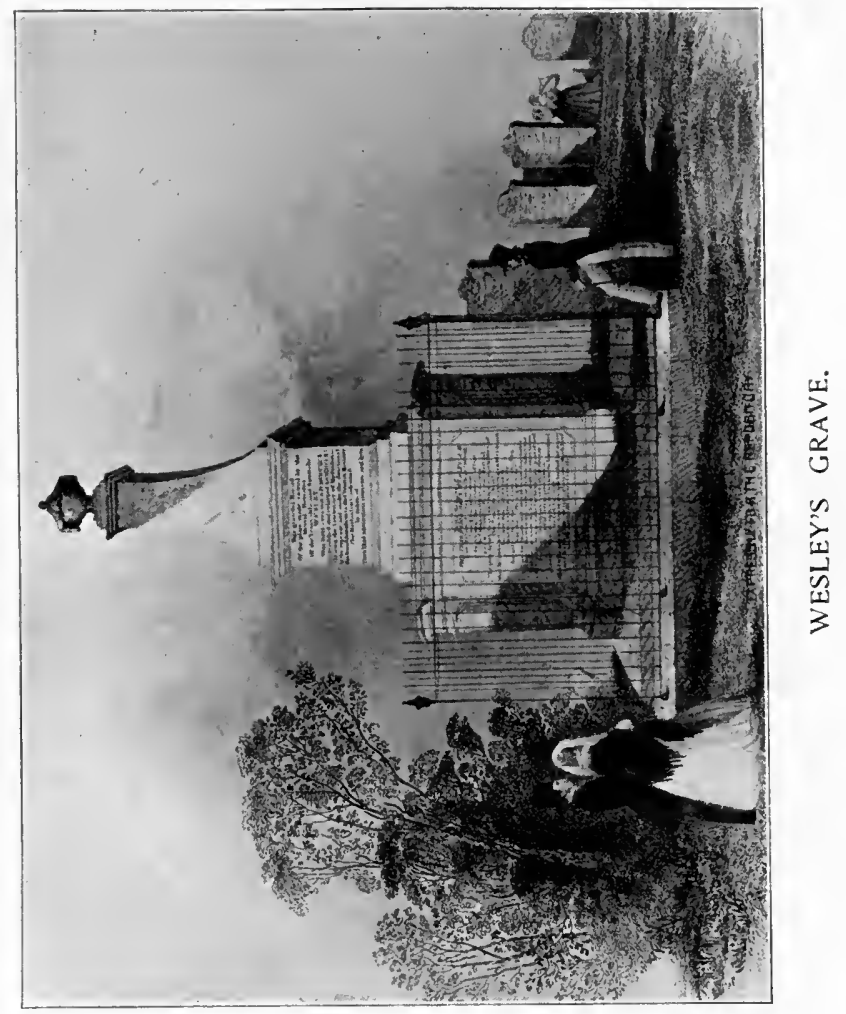




$$
\text { - }
$$




\section{CHAPTER XI.}

OUT OF THE OLD CENTURY INTO THE NEW.

CoKE sailed for London on the I4th of May, I 791 .

General protest compelled the bishops to consent to indefinite postponement of the Council; thus it was tacitly abolished, and none too soon, for it had "brought on such opposition in the minds of the preachers and people that it was hard to reconcile them one to another."

The General Conference assembled November I, I 792, in Baltimore. No official record is extant; but Lee was present, and has preserved in his "History" a synopsis of the proceedings.

James O'Kelly, of Virginia, proposed a radical change, to the effect that "after the bishop appoints the preachers at conference to their several circuits, if any one think himself injured by the appointment, he shall have liberty to appeal to the conference and state his objections; and if the conference approve his objections, the bishop shall appoint him to another circuit."

O'Kelly became a Methodist preacher in 1778 , was ordained in 1784 , and sent to a region in which he had attained popularity, and where for the eight years preceding this conference he had continued as presiding elder. He had come into note as a representative of the preachers against the authority and life-tenure of the superintendents, and was supported in his propositions by Freeborn Garrettson, Richard Ivey, Hope Hull, and others of equal 
weight. The chief debaters on the other side were Henry Willis, Jesse Lee, Thomas Morrell, Joseph Everett, and Nelson Reed.

Lee and Ware state that the arguments for and against the proposition were weighty, and handled in a masterly way.

Asbury's account of the matter is :

"Some individuals among the preachers having their jealousies about my influence in the conference, I gave the matter wholly up to them and to Dr. Coke, who presided. Meantime I sent them the following letter:

" "MY DEAR BRETHREN: Let my absence give you no pain; Dr. Coke presides. I am happily excused from assisting to make laws by which myself am to be governed; I have only to obey and execute. I am happy in the consideration that I never stationed a brother through enmity or as a punishment. I have acted for the glory of God, the good of the people, and to promote the usefulness of the preachers. Are you sure that if you please yourselves the people will be as fully satisfied? They often say, "Let us have such a brother;" and sometimes, "We will not have such a brother; we will sooner pay him to stay at home." Perhaps I must say, "His appeal forced him upon you." I am one; ye are many. I am as willing to serve you as ever. I want not to sit in any man's way. I scorn to solicit votes. I am a very trembling, poor creature to hear praise or dispraise. Speak your minds freely; but remember you are only making laws for the present time. It may be that, as in other things so in this, a future day may give you further light. I am,

$$
\text { " "Yours, etc., }
$$

Ware says that when the proposition was broached he did not see anything objectionable in it; but when it came 
to be debated, he disliked the spirit of those who advocated it, and wondered at their severity against what they had formerly defended. "Some of them said that it was a shame for a man to accept of such a lordship, much more to claim it. . . . One said that 'to be denied such an appeal was an insult to his understanding, and a species of tyranny to which others might submit, . . . but he could not.'"

O'Kelly's opponents replied that such assertions were reflections upon Wesley, who founded the plan and executed it until his death, and that to allow the appeal would make the itinerancy impracticable.

Ware thus concluded an interesting report of the debate: "Hearing all that was said on both sides, I was finally convinced that the motion for such an appeal ought not to carry." 1

On the final vote O'Kelly's proposition was defeated by a large majority.

The next morning a letter was received from him and others, informing the conference that, because an appeal from the decision of a superintendent in the making of appointments was not to be allowed, they could no longer sit with the body. Garrettson and two others were appointed to treat with him. He remained in the city, and had an interview with Bishop Coke, raising many objections against him and against the conference; the committee could not prevail, and he and the preachers whom he was able to persuade set off for Virginia.

The conference revised the Form of Discipline, but made no alterations affecting the essentials of doctrine and discipline. It was decided to convene another General Conference in four years, and that all traveling preachers who should at that time be in full connection should be entitled

1 "Memoir of Rev. Thomas Ware," pp. 221, 222. 
to a seat. Provision was made for the formation of districts, which was committed to the judgment of the bishops, who also were to appoint the time of holding district conferences. In the event of the death of bishops, or of their inability to travel through the districts, they should be regulated in every respect by the conference or presiding elders, ordination excepted. A rule was made for the trial of bishops, and the office of presiding elder was defined and made legal. For several years prior to this such officers had been appointed by the bishop, though some doubted his power to make such appointments.

The first rule limiting by time the tenure of a particular class of ministers was enacted at this conference; it provided that the bishops should not have power to appoint an elder to preside in the same district more than four successive years.

When the conference adjourned, Asbury hastened to the center of conflict in Virginia. O'Kelly had already induced William McKendree and several other preachers to decline to go to their appointments. By wise management Asbury effected a temporary compromise, which included a proposition to give O'Kelly, whose health was impaired, forty pounds per annum, the amount which he received as a presiding elder, provided he would forbear to excite divisions. He accepted the offer, and for some time received the appropriation, but afterward relinquished it.

The contests between the Republicans and Federalists were strenuous and exciting. The Republicans prevailed, and O'Kelly formed a church with the title of Republican Methodists. One traveling and several local preachers agreed with him, and they held conference after conference, promising great privileges to lay members. In some places they led away whole societies, and in others threw the church into confusion. Some meeting-houses they seized, 
and others the Methodists left in order to avoid contention. As the feud increased, O'Kelly became violent, and denounced Methodist ordination as spurious; yet himself proceeded to ordain others, and also to preach heretical doctrines. The church divided upon the name, and some proposed to call themselves the Christian Church; others objected, holding that this would imply that there were no Christians but of their own party. Finally several of his preachers seceded, and in less than ten years they became so divided and subdivided that it was hard to find two of one opinion. ${ }^{1}$

A similar division grew out of the personal interests of William Hammett, who had been minister of the Wesleyan connection in England, and more recently a preacher in the West Indies, and who came to this country early in $179 \mathrm{I}$. After preaching in Charleston, S. C., New York, and Baltimore, he returned to Charleston and left the Methodists, drawing off a large number of the Society and a few of the preachers, who took the name of Primitive Methodists, but their success was of short duration.

Among Hammett's adherents was William Meredith, who built a large meeting-house in Wilmington, N. C., and collected a numerous society of colored people, exerting an excellent influence over them. Difficulties arising between Hammett and himself, they separated. Meredith continued to prosper, and when his meeting-house was burned he erected one still larger, and at his death bequeathed to the Methodist Episcopal Church the meeting-house, a residence, and, so far as he could influence their choice, the members of his society.

Nineteen conferences were held in 1793 , and twelve extensive circuits with indefinite boundaries (one being entitled the Province of Maine) were added.

1 Lee's " History of the Methodists," pp. 202, 203. 
Bishop Asbury traveled as though determined to compass the entire territory included within the United States. At one place in South Carolina a gentleman refused to receive him "for love, money, or hospitality's sake," and he was compelled to apply at the negro quarters. Soon afterward he was in Kentucky selecting sites for schools, and encountering serious opposition owing to the wild state of the country. The brethren were obliged to travel armed, and formed a company of fourteen or fifteen for defense against their chief foes, the Indians.

The success of Methodism in New England occasioned systematic demonstrations of hostility. Magistrates in Connecticut would not recognize the preachers as regular ministers. George Roberts was fined for uniting two Methodists in marriage, and various members of the Society were thrown into prison. Gangs of "lewd fellows of the baser sort," with the implied sanction of the better class, often disturbed their meetings. Little was gained by their opponents in oral debate; for almost all the Methodist preachers were competent to defend themselves. Thomas Ware was even more successful in logical argument than Jesse Lee, although making no use of satire, which was so effective a weapon in the hands of the latter. Hope Hull was so persuasively eloquent that few could resist him.

Nathan Williams, A.M., a Congregational minister, who had gladly received the Methodist preachers, foreseeing the formation of a new denomination, which he honestly deprecated, delivered and published a sermon against them. It was accompanied by a letter from Dr. Huntington, of Coventry, Conn.

This pamphlet was issued with " the unanimous approbation of the Congregational Association, and at their cordial request." 
Mr. Williams denounced the pretension of a divine call to the ministry, claiming that it is tempting Heaven to give the pretender over to delusion. Dr. Huntington alleged that "the modern teachers are men of Machiavellian principles, and do without any scruples make use of truth and deceit promiscuously, as they judge will most promote the interest of their party." He describes John Wesley as " a flaming enthusiast, given to wild singularities," pointing out classes and class-meetings as among these.

Roberts replied with striking ability and power of sarcasm, and had an advantage in the tendency of the popular mind, which was against the compulsory support of the church by taxation. Just before he delivered his reply, a Baptist in the vicinity had been imprisoned for refusing to pay the parish minister's rate on the ground that he could not approve his creed.

Methodist preachers soon began to avoid discussion whenever possible, finding that the primary object of their ministry, the conversion of souls, could be more effectually promoted by their lives and labors than by controversy, though for years it was necessary, on certain occasions, to vindicate their doctrines against misrepresentation, and their characters against false charges, not only in New England, but in all parts of the United States. Mr. Williams, on further acquaintance, perceiving only good effects from their labors, "before he died welcomed his Methodist brethren to hold prayer-meetings in his own house."

Thomas Paine, who, during the War of the Revolution, had rendered to this country valuable services, was publishing his deistical works, which were widely circulated, and received by many with avidity. When Asbury preached in the woods at the town of Bennington, Vt., he found a large congregation, made up of deists and various sorts of unbelievers. 
The secession of O'Kelly reached its height in 1795 , and, combined with other impediments, caused a decrease of 4673 members among the whites, which, augmented by a decrease of 1644 among the colored, made a net loss of nearly 6500 . There was, however, an increase of 32 preachers.

Soon after Daniel Boone settled in Kentucky, Methodist local preachers followed, and a few years later Barnabas McHenry, who, by intellect, piety, and labor, made rapid progress, and was appointed presiding elder in four years after he entered the ministry, which occurred before he was quite twenty. He became a master of the English language, a theologian, a proficient student of the Greek New Testament, with sufficient knowledge of Hebrew and Latin to enable him to consult authorities with facility. Although suffering from disease induced by hardship, no minister of the State, of whatever denomination, maintained higher intellectual or moral rank. Indeed, "the adventures and hairbreadth escapes of McHenry, Lee, Kobler, Cook, Ogden, Burke, Garrett, and others would furnish a modern Tasso with matter for an epic." 1

Cokesbury College was burned on December 7, 1795 . The building was of brick, three stories in height, one hundred and eight feet in length, and forty feet in breadth. Intended to provide for the education of the sons of ministers, for orphans, and for Methodist people generally, it seems to have failed for a variety of reasons. In 1789 it had thirty students, ten partly supported by charity, and some maintained, clothed, and educated gratuitously ; Bishop Asbury was greatly encouraged by a revival among the students in that year. By 1792 the number had increased to seventy, and young gentlemen of good social position from the Southern States went to Cokesbury to complete their 1 Stevens's "History of the Metlodist Episcopal Church," vol. iii., p. 296. 
studies. The college was incorporated January 26, I 794, and authorized to confer degrees and enjoy other privileges and prerogatives guaranteed to regular colleges; but the New York Conference resolved, in view of its embarrassed condition, that nothing but an English free day-school should be kept there, and the number of professors was reduced to two.

A bout twelve o'clock on the night of the calamity the students were roused by the cry of "Fire!" The conflagration could not be extinguished, and the building was destroyed, with the library, philosophical apparatus, and important papers. The governor offered a reward of one thousand dollars for the supposed incendiaries, but could obtain no information sufficient to justify arrests.

Asbury's record was characteristic: "We have now a second and confirmed account that Cokesbury College is consumed to ashes, a sacrifice of ten thousand pounds sterling in about ten years! . . . Its enemies may rejoice, and its friends need not mourn. Would any man give me ten thousand per year to do and suffer again what I have done for that house, I would not do it. The Lord called neither Mr. Whitefield nor the Methodists to build colleges. I wished only for schools; Dr. Coke wanted a college. I feel distressed at the loss of the library."

The second regular General Conference assembled in Baltimore on the 2oth of October, I 796, one hundred and twenty ministers in attendance. An address was received from the British Conference. It reaffirmed the cardinal principles of Methodism, and exhorted the people in America called Methodists to increased fidelity and zeal, concluding:

"We consider you a branch of the same root from which we sprang, and of which we can never think but with 
inexpressible gratitude. . . We are, dearly beloved brethren,

"Your truly affectionate brethren in Christ Jesus, "The ENGLish Conference.

"Signed by order and in behalf of the conference.

"Thomas Taylor, President,

"Samuel Bradburn, Secretary."

Various important rules were enacted, among them a Deed of Settlement for the security of preaching-houses and all premises appertaining thereto; also a requirement that every traveling deacon should exercise his office for two years before be:ng eligible to that of elder, except in the case of missions, when the Yearly Conferences might elect the elders sooner if expedient; an addressand a system of regulations concerning the education of youth in seminaries were adopted, and ordered to be printed in the minutes.

A rule declaring that the student shall be "indulged with nothing that the world calls play" has been made a subject of ridicule, but only by those ignorant of what was intended. It was "worldly" games-cards, theaters, dancing, and every species of play technically so called-to which objection was made. Tradition says that these students leaped, ran, wrestled, and exhibited without restraint those natural impulses for healthful exercises in a sportive mood, and were allowed in all their so-called recreations the privileges of conversation, jovial laughter, and every form of pleasing social intercourse. If health, clearness of mind, rapid progress in learning, a situation favorable for forming habits of morality, and a well-grounded religious character be considered the ends sought by the instruction of youth, the system was almost perfect. Wherever it was applied, the proficiency and health of the students was a matter of common remark. 
The "Chartered Fund" was to be supported by voluntary contributions, the principal being funded under the direction of trustees, and the interest applied, according to certain regulations, for the relief of "distressed traveling preachers, their families, worn-out preachers, and the widows and orphans of preachers." A pathetic description of the sufferings, premature death, and dire distress of those in "age and feebleness extreme," and of widows and orphans, is made the basis of an earnest appeal, which was strengthened by the fact that many of the most efficient had been " obliged to retire from the general work because they saw nothing before them for their wives and children, if they continued itinerants, but misery and ruin."

Additional stringent rules were made against slavery.

The conference explained that Methodists were " not prohibited from marrying persons not of the Society," provided such "have the form and are seeking the power of godliness." If they wedded those who did not come up to this description it would be necessary to expel them. In a doubtful case the member of the Society must be "put back upon trial."

The regulations concerning the sale and use of spirituous liquors are:

"Ques. What directions shall be given concerning the sale and use of spirituous liquors?

"Ans. If any member of our Society retail or give spirituous liquors, and anything disorderly be transacted under his roof on this account, the preacher who has the oversight of the circuit shall proceed against him as in the case of other immoralities; and the person accused shall be cleared, censured, suspended, or excluded, according to his conduct, as on other charges of immorality."

This does not prohibit the retailing or giving of spirituous liquors, or subject the member to penalty or inquiry, 
unless something disorderly is transacted "under his roof" on account of the effects of the liquor. The conference adds this note: "Far be it from us to wish or endeavor to intrude upon the private religious or civil liberty of any of our people; but the retailing of spirituous liquors, and giving drams to customers when they call at the stores, are such prevalent customs at present, and are productive of so many evils, that we judge it our indispensable duty to form a regulation against them. The cause of God, which we prefer to every other consideration under heaven, absolutely requires us to step forth with humble boldness in this respect."

It was ordered that another bishop should be elected and ordained. After this decision was reached a difficulty arose concerning the manner of choosing or electing a man to be ordained a bishop, and before the point was settled Coke begged that the business should be laid over until the afternoon, which was done. "When we met in the afternoon," continues Lee, "the doctor offered himself to us if we saw cause to take him, and promised to serve us in the best manner he could, and to be entirely at the disposal of his American brethren, and to live or die among them.". 1 The conference agreed to this proposition, and concluded two bishops would be sufficient if he remained. Coke then presented the following instrument:

"I offer myself to my American brethren entirely to their service, all I am and have, with my talents and labors in every respect, without any mental reservation whatsoever, to labor among them, and to assist Bishop Asbury; not to station the preachers at any time when he is present, but to exercise all the episcopal duties when I hold a conference in his absence and by his consent; and to 1 " History of the Methodists," p. 247. 
visit the West Indies and France when there is an opening, and I can be spared.

$$
\text { "Signed, }
$$

"Thomas CoKe.

"Conference Room, Baltimore,

"October 27, 1796."

In this year there was a loss of 2627 members; for three years there had been an annual decline, amounting in all to nearly $\mathrm{I}, 000$ members. The losses were mostly in the Middle States, where prevailed the divisive spirit of which O'Kelly was the chief center. The number of preachers admitted on trial was ten less than the number lost from the traveling connection. Nine had died, twentyeight located, two had withdrawn, and one had been expelled.

On the 6th of February, I 797, Coke embarked for England. Asbury traveled to and fro, but on account of illness was obliged to rest four months in the year. Accompanied by Lee, he went as far north as Maine in April, I 798, returning South in October. He urged Lee to return and assist him in the South: "You and every man who thinks properly will find that it will never do to divide the North from the South. Methodism is union all over: union in exchange of preachers, union in exchange of sentiments, union in exchange of interest. We must draw resources from the center to the circumference."

In 1797 there was an addition of about 2000 members; 39 young preachers were admitted on trial, 43 of the traveling preachers located, 2 were expelled, and 2 died.

Unable to attend the conference in New England, Asbury wrote Lee a mournful letter "respecting the sufferings of his body," asking him to travel with him, or in case of necessity to take his appointments in the South. The conference by vote chose Lee to preside and to station the 
preachers, and at the close gave him a certificate signifying their approbation of the bishop's plan for their traveling together.

Wherever Asbury went he gave up the presidency to the presiding elders, and in his addresses to the conferences deplored the weakness of the episcopacy.

There was an increase of 1506 members in 1798 . The death of John Dickins, of the yellow fever, in Philadelphia, in the fifty-second year of his age, was declared in the minutes to be "more sensibly felt than that of any other preacher who has died since American Methodism arose." His services cannot be overestimated. It was he who proposed the title of "The Methodist Episcopal Church." Four years before Coke's arrival he had suggested to Asbury the plan of a Methodist academic institution. He was born and educated in London, was a master of Latin and Greek, and was especially learned in mathematics. He founded the Methodist Book Concern, and " his skill and fidelity as editor, inspector, and corrector of the press were exceedingly great." Ezekiel Cooper was appointed editor and general book-steward, to fill the vacancy caused by the death of Dickins.

Methodism was established in Augusta, Ga., in 1799, and Tobias Gibson preached at Natchez, on the Mississippi, being the first Methodist preacher that went into that wilderness. Although so ill as to be unable to take a circuit, and making the tour for the benefit of his health, he was the means of the conversion of many settlers and of the establishment of a society.

The total number of members in 1799 was 61,35 I, of whom, as before, about one in five were colored. The number of traveling preachers was 272 . There were three deaths among the ministers, the most noteworthy being that of Hezekiah Calvin Wooster, who commenced his ministry 


$$
\text { i }
$$




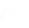


in Massachusetts in 1793 , later spending two years upon circuits in New Jersey and New York, and in Canada toiling three years, preaching almost daily.

The year I 800 was very prosperous, and in every part of the country there was a gain except in Pennsylvania, where was a decrease of 122.

The third regular General Conference assembled in Baltimore on the 6th of May, I 9 being present.

Asbury had informed preachers in different parts of the connection that on account of mental weariness and physical feebleness he intended to resign his position as superintendent of the Methodist connection, and would take his seat in the conference on a level with the elders; and he had written his resignation with the intention to deliver it as soon as the conference met. He was therefore asked to state what he had determined to do. In response he said that his affliction had been such that he had been under the necessity of having a companion, that his debility had several times obliged him to locate, that he could only travel in a carriage, and he did not know whether this conference as a body was satisfied with such parts of his conduct.

On motion of Cooper, the conference unanimously resolved that they "considered themselves under many and great obligations to $\mathrm{Mr}$. Asbury for the many and great services he has rendered to this connection; . . . and that this General Conference do earnestly entreat Mr. Asbury for a continuation of his services as one of the general superintendents of the Methodist Episcopal Church, as far as his strength will permit." 1

The situation concerning the episcopacy was seriously complicated. When Coke returned from England in 1797 , he brought an address from the British Conference to

\footnotetext{
1 "General Conference Journals," vol. i., p. 33.
} 
American Methodists, in which they urged that he might be allowed to return to Europe speedily.

The address was submitted to the Virginia Conference, and Asbury, with their approbation, addressed a letter to the British Conference, and then unofficially consented to Coke's tarrying for a time in England, which the latter having done, he now appeared to fulfill his engagement made in 1796 or to be honorably released. The conference complied with the request of the English body upon condition that Coke return to America as soon as his business would allow, but certainly by the next General Conference.

It was decided by a large majority that one bishop should be elected and ordained, and that the vote should be taken by ballot.

Various propositions were rejected, which if adopted would have made Methodism something radically different from that which it has become, and it was determined that the bishops were to be equal in every particular.

The result of the first ballot, which was "supposed defective," was a tie, and upon the second there were fiftynine votes for Richard Whatcoat, fifty-five for Jesse Lee, and one blank. Whatcoat was in the sixty-fifth year of his age when elected. As a preacher, his pathos was all-subduing, so that congregations were moved "as the leaves of a forest by the power of a mighty wind." To this, says Dr. Bangs, was added a meekness and modesty of spirit which, united with simplicity of intention and gravity of deportment, commended him as a pattern worthy of imitation. "Under the guise of a modest and unassuming manner he also possessed, like his old friend and classmate, Asbury, though in an inferior degree, the gift and faculty of authority." 1

It was shown that the existing rule which prevented the 1 "Lives of Methodist Bishops," p. I 16. 


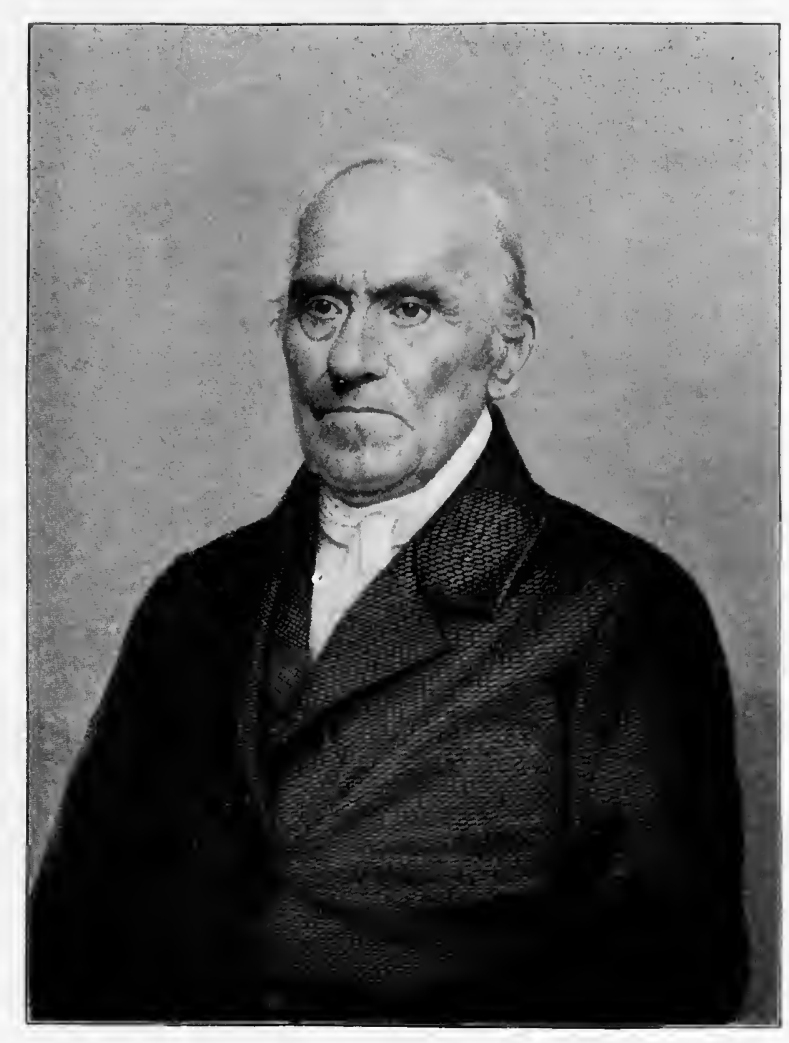

Henny Bochn 


$$
\text { , }
$$


members from increasing the number of their slaves by purchase tolerated an increase by birth, and also that the removal of members from one State to another caused the leaving of a husband or a wife behind held in bondage by another, thus separating man and wife, which was a violation of the laws of God, and contrary to the peace and happiness of families. After the rejection of various propositions to strengthen the rule, a committee was appointed to prepare an affectionate address to the Methodist societies, pointing out the evil of the spirit and practice of slavery, and the necessity of doing away with it so far as the laws of the respective States would allow, and that the said address be laid before the conference for its consideration, and if agreed to, be signed by the bishops. A committee was also appointed to draft proper addresses to the State legislatures from year to year for the gradual abolition of slavery. It was also ordered that if by any means any of the traveling preachers became owners of a slave or slaves they should forfeit their ministerial character in the Methodist Episcopal Church, unless, if practicable, they executed legal emancipation of such slave or slaves.

A greater revival took place in Baltimore at this conference than had occurred during the session of any previous General Conference. The sermon preached on Sunday morning by Coke was followed by the ordination of Whatcoat to the office of bishop by Coke and Asbury, assisted by several elders. Henry Boehm, traveling companion of Asbury, and intimately acquainted with Whatcoat, characterizes the scene in a single sentence: "Never were holy hands laid upon a holier head." Lee preached a wonderful sermon in the market-house that afternoon.

As the preachers returned to their stations they naturally carried with them the influence of this revival, and lighted similar flames wherever they went. 
In and near the place where was held the first Annual Conference after the adjournment of the General Conference, not far from Baltimore, within a few days one hundred and seventeen joined the Society. At the same time in Tennessee and Kentucky arose the most remarkable revival of religion ever seen in the West. In Philadelphia, in the western part of Maryland, in Vermont, in New Hampshire, in Connecticut, especially in the Tolland circuit and in New London, there was a greater work in the conversion of souls than had ever been known. Similar results followed the preaching of Methodist ministers during the year I 801 , many thousands being added to the societies.

During this period "camp-meetings" arose. Late in I 799 or early in I800 John and William Magee, brothers, the first a Methodist local preacher, the second a Presbyterian minister, started from their settlement in Tennessee to make a preaching-tour into Kentucky. Such interest attended their work that at the next meeting many families encamped in the woods. The coöperation of these brothers was so pleasing an example of fraternity that the earliest camp-meetings included members of every denomination. ${ }^{1}$

Sometimes as many as twenty thousand were present. Presbyterian and Methodist ministers united in the work. The assemblage divided into groups, which were addressed by as many speakers. So many were struck to the ground at one meeting that, to prevent their being trodden underfoot by the multitude, they were laid out in order on two squares of the central meeting-house. But at another meeting, at Cane Ridge, the number that fell was reckoned at three thousand, among whom were several Presbyterian ministers, who, according to their own confession, had previously possessed only a speculative knowledge of religion.

The Presbyterians ceased to take interest in the meetings

. 1 "Methodist Magazine" for 1821, p. 189. 
because of the excitement which attended them. It was not in harmony with the genius of that body.

Able men were recruited by Western Methodism for the ministry, among them Jacob Young. Philip Gatch, so effective in the East, had now become influential in Ohio. For years he sat as a magistrate on the bench of the Court of Common Pleas, and was a delegate to the convention which framed the State constitution. Scott, another of the early Methodist preachers, became judge of the Supreme Court of Ohio; and the societies, instead of being regarded as ephemeral, in a very few years included among their members many, and in some sections most, of the substantial citizens.

A revival in 1801 extended along the shore of Lake Ontario to Niagara, and thence to Long Point on the northwestern shore of Lake Erie. The Long Point circuit was formed in the latter part of 1802 , chiefly through the labors of Nathan Bangs. Among the names not to be forgotten are those of James Coleman, C. Warner, a layman, Sylvanus Keeler, and Seth Crowell. The work also extended into Lower Canada.

Antislavery agitations, and especially the resolutions of Methodist conferences memorializing legislatures against slavery, created a serious disturbance in Charleston, S. C., where were stationed George Dougherty and John Harper. Harper had received some pamphlets containing those resolutions, and that fact, becoming known, caused great excitement. The obnoxious documents were demanded by the mayor, and burned in his presence; and a mob gathered to assault Harper, who escaped; but his colleague, Dougherty, was dragged to the pump, and would have been suffocated had not Mrs. Kingsley, a godly woman, rushed forward and, placing herself between the crowd and, their victim, stuffed her shawl into the spout. Astonished, 
they paused, and at that instant a gentleman of high character stepped with drawn sword among them, took Dougherty by the hand, and, declaring his purpose to protect him at all hazards, led him away.

Dougherty was a native of South Carolina, early became a Methodist, and, being a teacher, was subject to persecution as the "Methodist schoolmaster," and treated with indignity by every crowd through which he passed. Sprague's "Annals of the American Pulpit" ${ }^{1}$ contains an elaborate description of him by Lovick Pierce, who had frequently heard him preach, and who says that his supremacy as a preacher in his day was never disputed by any competent witness. The effects of the exposure which he endured by being drenched with cold water in the way described were permanent. He sank into consumption, and died prematurely.

There was a difficulty in the Methodist church of Philadelphia in 1802 , which resulted in the withdrawal of many members. They adhered to the doctrines of Methodism, and wished to be governed by its discipline, but not being able to harmonize with those from whom they seceded, they established a separate place of worship in a building erected for an academy by George Whitefield. Nevertheless they made an appeal to the bishop to send them a Methodist preacher, and it was agreed, with only one dissenting vote, that their request should be granted on such terms as the bishop could make. This furnished a precedent for similar adjustments elsewhere.

Methodism was now rapidly increasing, adding 33 preachers in the year 1803 , and 17,366 members, of whom a little more than one quarter were colored.

1 Pages 291-295. 


\section{CHAPTER XII.}

TROUBLOUS YET SUCCESSFUL YEARS.

THE fourth regular General Conference convened in Baltimore, May 7, I 804, with Coke, Asbury, and Whatcoat present.

Coke moved that " no regulation or law should finally pass the conference until it had been read at three distinct sittings, and had received the approbation of the conference each time." This attempt to introduce English parliamentary law was defeated by fifty-six negative votes in a total of one hundred and three. He then moved that "no new regulation or law should finally pass the conference until it had been read at three distinct sittings." This also was lost.

The Articles of Religion had been adopted prior to the close of the Revolutionary War; consequently the words "Constitution of the United States" were now substituted for the "General Act of Confederation," and the declaration was inserted that the said States are a "sovereign and independent nation," and "ought not to be subject to any foreign jurisdiction."

Only those who had "regularly traveled four years" were eligible to membership in the General Conference, and it resolved that the time of any preacher's traveling under the direction of a presiding elder should not be reckoned as a part of his probation, which should date 
from his reception by a conference. This action determined the ineligibility of Taylor of the Western Conference, and Ryan, Lyon, Gruber, and Knowlton of the Philadelphia. It would appear that considerable excitement attended some of the debates; for Bishop Whatcoat "arose to recommend the separation of passion or ill will in debate, and that reason should rule in every loving contest." 1 Coke was allowed to return to Europe, on condition that he should hold himself subject to the call of three of the Annual Conferences to return, and at the furthest should attend the next General Conference.

After long discussion of several motions on slavery, Freeborn Garrettson moved that "the subject of slavery be left to the three bishops, to form a section to suit the Southern and Northern States as they in their wisdom may think best, to be submitted to the conference." Bishop Asbury refused to act upon that vote, the result of which was a variety of motions, ending in the adoption of a resolution, proposed by Ezekiel Cooper, that " a committee be formed, one from each conference, to take the different motions and report concerning slavery." Finally an elaborate system was adopted, reaffirming the evil, instructing the conference and elders to be cautious in admitting persons to official stations, requiring security from slave-holders, and compelling any traveling preacher becoming the owner of a slave to forfeit his ministerial authority unless he would execute a legal emancipation conformable to the law of his State. To every slave-holder the preacher must speak fully and faithfully on this subject, and every member of the Society selling a slave, except at his or her request in cases of mercy and humanity, with the approbation of a committee of three male members appointed by the preacher, shall be excluded from the Society. It

1 "General Conference Journals," vol. i., p. 53. 
was ordered that if any member purchased a slave he should submit to the judgment of the Quarterly Conference, which should fix the number of years which the said slave must serve to redeem himself; and the owner should be excluded if he would not conform and execute a legal instrument, varying as the slave was male or female, and providing for the manumission of children. And if any member of the Society bought a slave with a certificate of future emancipation, the terms thereof should be subject to the decision of the Quarterly Conference. But this stringent paragraph closes thus: "Nevertheless the membership of our societies in the States of North Carolina, South Carolina, and Georgia shall be exempted from the operation of the above rules."

A motion to abolish presiding elders was lost after long debate by a very narrow margin. Authority was given to remove the Book Concern from Philadelphia to New York, and Cooper was reëlected general superintendent thereof. Although the conference ostensibly sat in secret session, a resolution was passed admitting as spectators official members of the church. A resolution of unusual importance was passed which provided that the bishop should not allow any preacher to remain in the same station more than two years successively, except the presiding elders, superannuated and worn-out preachers. A motion to add to this "except in cases of sickness of families" was lost.

The tendency to increased length of term of service had become marked. As the city of New York was in the hands of the British, and thereby communication with the conference was cut off, Samuel Spraggs, by arrangement with the people, had served as pastor of John Street for five years in succession; yet it was thought by the conference a wise policy to appoint him for a sixth year, 
associating with him John Dickins, who was reappointed the next year.

Wesley wrote to Asbury, September 30, I785: "At the next conference it will be worth your while to consider deeply whether any preacher should stay in one place three years together. I startle at this. It is a vehement alteration in the Methodist discipline. We have no such custom in England, Scotland, or Ireland."

Asbury wrote to Thomas Morrell in I 793: "I am convinced there ought to be a change generally, presiding elders and others; this I aim at, but there are great difficulties. I see the propriety of having men to command that are firmly fixed in our church government and are as heartily united to the president of the connection. All my woods and wilderness troubles vanish in a moment when I have to take one single grain of conference tartar." 1

A case which some years later gave Asbury trouble was that of the Rev. Cyrus Stebbins. A man of influence with the cultivated classes, he had been stationed in Brooklyn and New York, and was in I 800 appointed to Albany, reappointed the next year, and again, and for a fourth time. More than one of these appointments were made against the convictions and wishes of Asbury, under the pressure of Stebbins and a self-constituted committee claiming to represent the society, and under the threat that to remove him would rend the church. When Stebbins was removed he became dissatisfied, and withdrew from the Methodists, becoming a minister of the Protestant Episcopal Church, in which body he commanded the respect of bishops, clergy, and laity. Wakeley states that the reason for withdrawal which Stebbins assigned was unbelief in the doctrine of Christian perfection as held by Methodists.

1 No. I 7 of the Morrell Letters, "Christian Advocate and Journal," Feb. ruary 13,1851 . 
A detailed history of the origin of this time-limit was communicated in a letter to the "Christian Advocate" by the late Aaron Hunt, over the signature of "Luther."

"The circumstances which led to the adoption of that rule are not fully known at this day. Soon after the commencement of the present century two or three cases occurred which gave the Bishop great annoyance. Some preachers, finding themselves in pleasant stations, and (by the aid of self-constituted committees) believing, of course, that they could do better in the place than any one else, objected to removal, while the more pious part of the society would have preferred a change, but the officious committee prevailed. One of these unhappy cases came under our personal knowledge when in company with the Bishop, which gave the venerable Asbury much anxiety, seeing that to remove the incumbent would rend the society, and that to leave him would result in injury to the Church. Finally they prevailed, and evil followed. In conversation with the bishop we suggested the above rule, to which he pleasantly replied, 'So, then, you would restrict the appointing power?' 'Nay, sir,' was the reply; ' we would aid its execution, for in the present case it seems to be deficient.'

" His laconic reply of 'So, so,' encouraged me at the ensuing General Conference of 1804 to present the resolution, which was signed and seconded by the Rev. Joseph Totten, of the Philadelphia Conference. . . . Of course it was laid on the table for the present. It was talked over out of doors, and scanned in all its bearings by the fireside, and when called up again, after some discussion, it passed with a very general vote." 1

Papers in the hands of Dr. Albert S. Hunt, secretary of the American Bible Society, and grandson of Aaron Hunt,

1 "Christian Advocate," July 12, 1883. 
show that the case referred to in his letter was that of Stebbins.

Lee's account of the matter is: "In some cases prior to that rule the bishop had appointed a preacher or preachers to the same place for three years together. We now determined on a better plan, and formed this rule to prevent any preacher from wishing or expecting such an appointment in future." 1

For a considerable period after the Revolutionary War the Methodism of the British provinces was connected directly with that of the United States. Methodism began in Nova Scotia in 1779 , as a result of the conversion of William Black, who had been led to embrace its doctrines and seek its experience by conversation with certain Methodists newly arrived from Yorkshire, and by the reading of the Rev. John Wesley's sermons. Black was zealous and sagacious, and seven years later visited Coke and Asbury at the Christmas conference. He also went to Philadelphia and New York, and was ordained by Coke as deacon and elder, and obtained from the American conference six additional missionaries for the colonies. In the minutes of American Methodism for I791 the preachers for the provinces were thus distributed: William Black, elder; Halifax, William Jessop, John Mann; Liverpool, Thomas Whitehead; Shelburne, William Early ; Cumberland, Benjamin Fisler; Newport, John Cooper; St. Johns, John Ragan; Annapolis, James Boyd.

But these were not the first A merican preachers appointed to the Eastern provinces, for at the Christmas conference Freeborn Garrettson volunteered for Nova Scotia, and embarked for Halifax, where he established a society. $\mathrm{He}$ was accompanied by James O. Cromwell.

The progress of Methodism in these colonies under the 1 Lee's "History of the Methodists," pp. 298, 299. 
preaching and superintendence of the men thus sent forth was most encouraging, and Garrettson's influence was almost equal to that of Wesley in Europe and Asbury in the United States. The correspondence between Wesley and Garrettson concerning this work contains information of inestimable value. When Garrettson sailed from Nova Scotia for Boston, April 10, 1787, he left as evidence of his fidelity and success in his Lord's vineyard about six hundred members in the various societies.

New Brunswick, Prince Edward Island, and Cape Breton had received Methodism and all its institutions from Nova Scotia prior to 1802 , but by 1804 the American preachers were withdrawn from these provinces, and so far as they were supplied it was from England.

According to the best Canadian authorities, Methodism was introduced into the island of Newfoundland by Lawrence Coughland a few months prior to Embury's first sermon in the city of New York. Coughland had been received on trial in I 755 by Wesley. A number of Yorkshire Methodists settled, in 1772 , in Nova Scotia, and a year later, when he returned to England, Coughland's work had prospered to such an extent that there were enough local preachers to keep the societies alive for the next twelve years. The British Conference, in I 785, regularly appointed John McGeary to that island. The following year a provincial Methodist conference was held in Halifax, at which five hundred and ten members were reported and six preachers stationed.

A local preacher and soldier named Tuffy had preached the first Methodist sermon in Quebec in I 780, and meetings were held at irregular intervals at different points. George Neal, an Irish local preacher, zealously and effectively preached in the vicinity of Fort Niagara six years later. But in the year 1790 William Losee, a preacher on 
trial in the Methodist Episcopal Church in the United States, but without a definite appointment, ranging at large, came into the St. Lawrence and Bay Quinté country. The first regular class was organized at Adolphustown, on Sunday, February 20, I791. Losee returned to the East, and in the minutes of $\mathrm{I} 79 \mathrm{I}$ he appears as stationed by the New York Conference in the Kingston circuit, but the next year was ordained deacon, and appointed to the province of Upper Canada, accompanied by Darius Dunham, who had received elder's orders. They prospered to such an extent that by I799 Dunham was a presiding elder, with three circuits and four preachers. Samuel Coate was at Oswegatchie, and James Coleman and Michael Coate at Niagara.

Joseph Sawyer, of the New York Conference, visited Montreal in 1802 , and formed the first class. The same year Peter Vannest and Nathan Bangs toiled on the Bay Quinté circuit; and Samuel Merwin, of the same conference, who was stationed at Montreal, visited Quebec in 1803 .

A district comprising seven hundred and eighty-seven members, known as "Upper and Lower Canada," in I 804 was superintended by Samuel Coate, presiding elder, among whose preachers were Martin Ruter and Nathan Bangs.

Quite early in the history of American Methodism dissatisfaction arose among the colored membership, and it was part of a common tendency among that people in all denominations, growing out of the oppressive spirit of the whites, the direct consequence, if not a necessary concomitant, of slavery. They appear to have been somewhat aroused by Question 25 in the minutes of the Conference of 1780 : "Ought not the assistant to meet the colored people himself, and appoint as helpers in his absence proper white persons, and not suffer them to stay late and meet by themselves? Ans. Yes." 


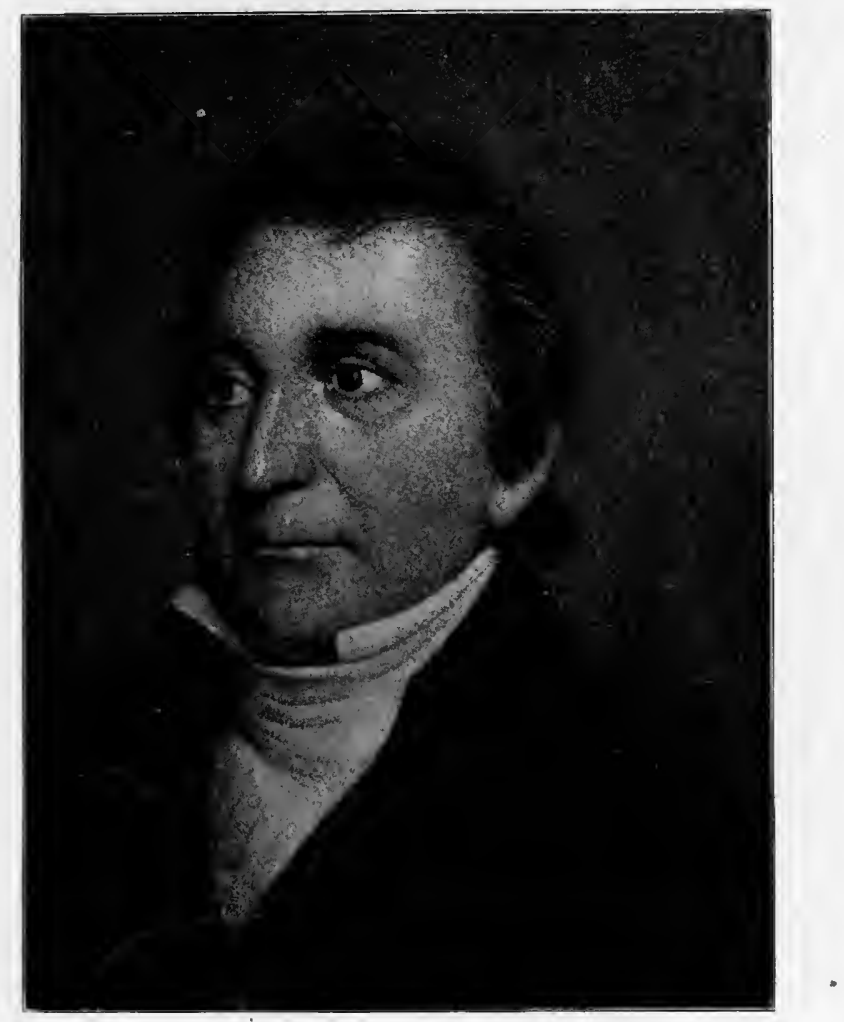

MARTIN RUTER. 
Most of the young preachers who had been received into the Methodist ministry during the Revolutionary War were born and educated in slave-holding sections. "The Rev. Freeborn Garrettson could truthfully say that he did not know it was wrong. He had never read a book on the subject, or been told that it was wrong." 1 All the conferences between I776 and I 787 were held in slaveholding States, and in I 783 only about two thousand of the members resided in what in later years were known as the free States.

In Philadelphia, in 1787 , the colored people belonging to the Methodist societies met to consider their condition. Being opposed, they withdrew from the church, began a chapel, and Bishop White, of the Protestant Episcopal Church, ordained a colored preacher for them. In I793 Richard Allen, a slave who had bought his freedom and grown rich and influential, erected on his own land, for people of his race, a church. Asbury dedicated this church, which was named Bethel, and the congregation adopted as a part of their platform the following:

"We consider every child of God a member of the mystical body of Christ ; . . . yet in the political government of our church we prohibit our white brethren from electing or being elected into any office among us, save that of a preacher or public speaker."

On June IO, I 794, they adopted a declaration of their reasons for desiring a separate place of worship:

"Whereas, From time to time, many inconveniences have arisen from white people and people of color mixing together in public assemblies, more particularly in places of public worship, we have thought it necessary to provide for ourselves a convenient house to assemble in separate from our white brethren:

1 Daniel de Vinne, letter to "Zion's Herald," 1844. 
"( 1 ) To obviate any offense our mixing with our white brethren might give them.

“(2) To preserve as much as possible from the crafty wiles of the enemy our weak-minded brethren from taking offense at such partiality as they might be led to think contrary to the spirit of the gospel, in which there is neither male nor female, barbarian nor Scythian, bond nor free, but all are one in Christ Jesus.

"(3) That we might the more freely and fully hold the faith in unity of spirit and the bands of peace together, and build each other up in our most holy faith."

They adopted a charter, placing their edifice under the control of the Methodist Episcopal Church, but did not execute the deed in the prescribed form. Asbury, on the I I th of June, I 799, ordained Allen a deacon, he being the first colored minister so ordained in the United States; and the members of Bethel Church made a contract to remain under the discipline of the Methodist Episcopal Church and the jurisdiction of a white elder.

The bishops obtained leave, in the General Conference of I 800, "to ordain local deacons of our African brethren in places where they have built a house or houses for the worship of God, provided they have a person among them qualified for the office, and he can obtain an election of two thirds of the male members of the society to which he belongs, and a recommendation from the minister in charge and his fellow-laborers in the city or circuit." When this rule was formed many of the preachers were opposed to it, especially those from Southern States. Some of these moved that it should not be printed in the Form of Discipline, and a vote of the conference was obtained to enter it only on the journals; and most of the preachers were not willing that it should be made public.

Slavery being legal in the State of New York, there were 
many slaves in the metropolis, and a number belonged to Wesley Chapel. They were required to sit in the gallery. Sometimes their masters would not suffer them to come to hear the Word, and in the first letter of Boardman to Wesley, in I 769, he speaks of one who said, "I told my master I would do more work than I used to do if he would let me come-nay, I would do everything in my power to be a good servant." Asbury in 1772 speaks of administering the Lord's Supper to the colored people in New York, and says, "At the table I was greatly affected with the sight of the negroes, seeing their sable faces at the table of the Lord." A number of colored members of the Methodist Episcopal Church wishing to exercise their spiritual gifts among themselves, and thereby, as they thought, be more useful to one another, formed in 1796 what was practically a separate congregation.

The historical introduction to the Discipline of the African Methodist Episcopal Zion Church thus summarizes the causes of complaint on the part of the colored people in the city of New York: "Caste prejudice forbade their taking the sacrament until the white members were all served. This and the desire for other church privileges denied them induced them to organize among themselves, which they did in the year I 796. . . . In the year I 800 they built a church, and called it Zion; . . . which church was, as regards its temporary economy, separate from the Methodist Episcopal Church from its first organization." 1

A contract was made between that body and the Methodist Episcopal Church, the first sentence of which is: "This article of agreement, made this sixth day of April, I 80I, between the Rev. John McClaskey in behalf of the Methodist Episcopal Church of the United States of Amer-

1 "Doctrines and Discipline of the African Methodist Episcopal Zion Church in America" (A. M. E. Zion Book Concern, New York, 1892), p. 8. 
ica of the one part, and the trustees of the A. M. E. Zion Church of the city of New York of the other part, for themselves and their successors in office," etc. ${ }^{1}$

Under this contract, having no ordained ministers of their own race, the church had the services of ministers of the Methodist Episcopal Church for about twenty years.

The first Protestant sermon preached in the State of Alabama was delivered by the eccentric Lorenzo Dow, who wandered into that wilderness in 1803 , and also traveled there again during the following year, the seed which he sowed bringing forth much fruit. Three years later Asbury applied in the South Carolina Conference at Charleston for missionaries to Alabama, and those who responded reported within two years eighty-six members.

Methodist preachers did not venture until 1802 within what is now the State of Indiana; there were then but a few settlers, and in the year 1807 it contained but one circuit, one preacher, and sixty-seven members.

Illinois had but two hundred and fifteen inhabitants in the year I800; but four years later Benjamin Young, brother of Jacob, was sent as a missionary, and at the end of one year he reported sixty-seven members.

The first Methodist preacher in Michigan was Freeman, a local preacher who began in 1803 , wandering far into the interior, and also preaching in Detroit. Nathan Bangs, entering from Canada, preached in that city in $\mathrm{I} 804$, though without visible success. Subsequently William Case crossed from Canada and delivered sermons; and a short time afterward William Mitchell, a local Methodist preacher, organized the first Methodist society in Detroit, which was also the first in the State. ${ }^{2}$

Tennessee, where Methodism was prospering, became

1 "One Hundred Years of the A. M. E. Zion Church," by Bishop J. W. Hood (A. M. E. Zion Book Concern).

2 Pilcher's "History of Methodism in Micligan." 


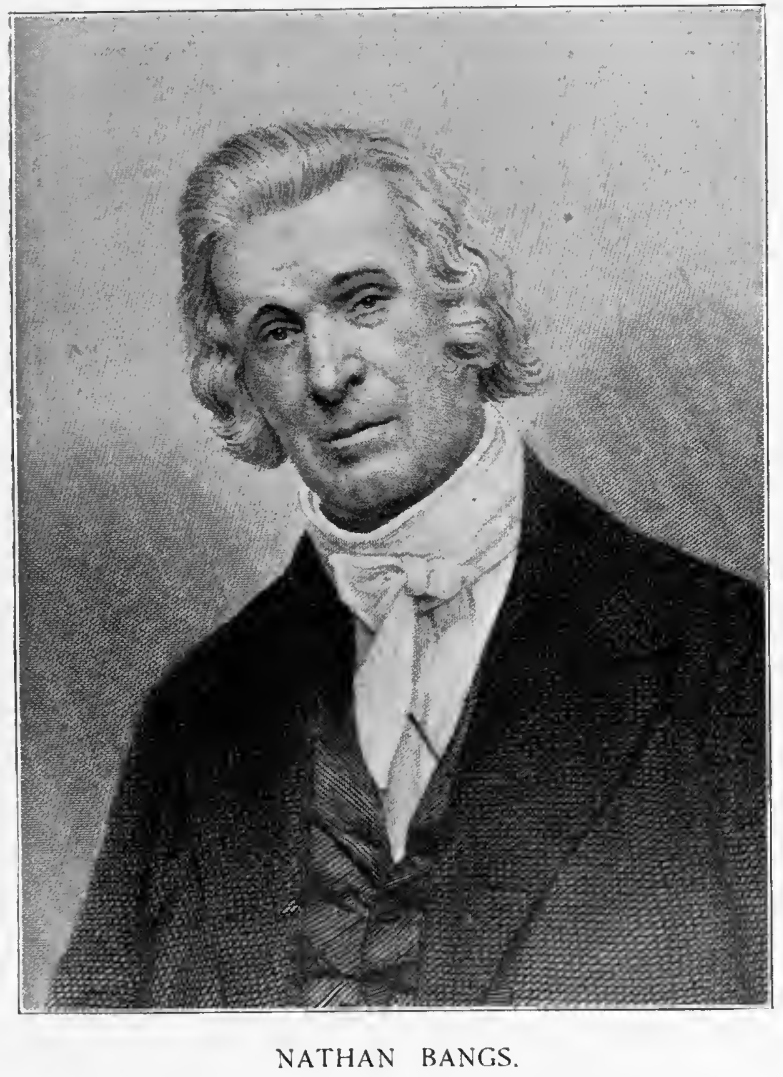


the headquarters of the itinerant preachers who were exploring the southeastern portions of the country. In 1805 Asbury dispatched Elisha W. Bowman as a missionary from the Western Conference to introduce Methodism among the English settlements of the Territory of Louisiana. He formed a circuit, which was attached to another styled the South Mississippi, and together with it formed the Mississippi district, which appears first in the minutes of 1806 . Few of the settlers were Americans, and these were generally so ignorant that Bowman reported that they knew little more about the need of salvation than the Indians. Some, after he had preached, asked him what he meant by "the fall of man," and when it was that he fell. Bowman was obliged to teach them to sing, and in fact "to do everything that is like worshiping God"; and he remarks that if they came to hear him once they thought they had done him a great favor. ${ }^{1}$

James Russell was admitted to the South Carolina Conference in 1805 . On account of ignorance he had been refused a license to exhort, but the authorities were unable to maintain their attitude, for no man so eloquent had appeared among them; he was licensed by the South Carolina Conference before he could read, and carried his spelling-book with him around the circuit, seeking assistance in its lessons even from the children of the families with whom he lodged. So soon as he had acquired the art of reading he advanced in self-culture with a rapidity commensurate with his oratorical ability, and became noted as an English scholar and a man of refined taste. In Sprague's "Annals of the American Pulpit" interesting references are made to him by Bishop Wightman, who represents him as one of the founders of the Southern Methodist Church, famous in three States

1 Stevens's "History of the Methodist Episcopal Church," vol. iv., pp. 399-402. 
as among the most eloquent and powerful preachers of his time.

Bishop Whatcoat died in Dover, Del., on the 5 th of July, 1806, at the residence of Richard Bassett, Asbury being then en route to visit his colleague, and within one hundred and thirty miles of the place. Asbury speaks of him as " that father in Israel, my faithful friend for forty years, a man of solid parts, a self-denying man of God, who had been sixteen years in the ministry in England, Wales, and Ireland, and twenty-two in America; twelve as presiding elder, during four of which years he was stationed in cities or traveling with me; and six years in the superintendency." "A man," said he, "so uniformly good I have not known in Europe or America."

Lee notes certain peculiarities not specified by Bishop Asbury: "He seldom complained of any difficulties with which he met; he was especially clear and plain in his explanations of the Scriptures, with which he was particularly acquainted." He was " among the best of men for meekness and patience, humility and sobriety ; for watchfulness over his words, and for a smooth and even temper; and, withal, for gifts and animation in preaching, especially in the last part of his life... In his death the preachers have lost a pattern of piety, and the people have lost an able teacher."

Methodism was introduced into the new Territory of Missouri, considered a part of Louisiana, in 1807. Most of the early settlers were Roman Catholics; but the tide of migration was strongly setting in that direction, and already there were sixteen thousand inhabitants, one fifth of whom were slaves. The Rev. John Travis, who outlined and traversed the new circuit, owing to the scattered condition of the settlers, the badness of the roads, the swampy character of the lands near the Mississippi, 
met with many difficulties, but at the end of the year reported fifty-six members.

Throughout this year general revivals took place in Maryland, Delaware, Virginia, and Georgia, and one of special interest occurred in the city of New York. The record of the year showed an increase of 14,020 members and 64 preachers, giving a total of 144,590 members and 516 preachers. There was an increase of 2606 members of African descent, making nearly 30,000 , notwithstanding disaffection among that people in certain sections. 


\section{CHAPTER XIII.}

INTRODUCTION OF REPRESENTATIVE GOVERNMENT.

WHEN the General Conference of 1808 assembled in Baltimore on the first day of May Asbury was the only bishop present, Whatcoat having died, and Coke being in Europe. There were thirty-two members from the Philadelphia Conference, among them Thomas Ware and Henry Boehm (who survived until the present generation, becoming by his writings and by his public and private verbal communications a valuable contributor to the history of American Methodism); thirty-one from the Baltimore, among them Stephen G. Roszel, Enoch George, Asa Shinn, and Robert R. Roberts; nineteen from the New York, including three whose names appear frequently in the history of Methodism-Garrettson, Cooper, and Bangs; eighteen from the Virginia, the most widely known being Philip Bruce and Jesse Lee; eleven from the South Carolina, among whom were William Phœbus, Lewis Myers, and John Gamewell; eleven from the Western, led by William McKendree; and seven from the New England, all of whom were already influential, and two, Joshua Soule and Elijah Hedding, conspicuous.

The relations of Coke to American Methodism, which, although on the whole of great service, had always been an occasion of discussion, had now become so delicate that their final settlement was imperatively demanded. 


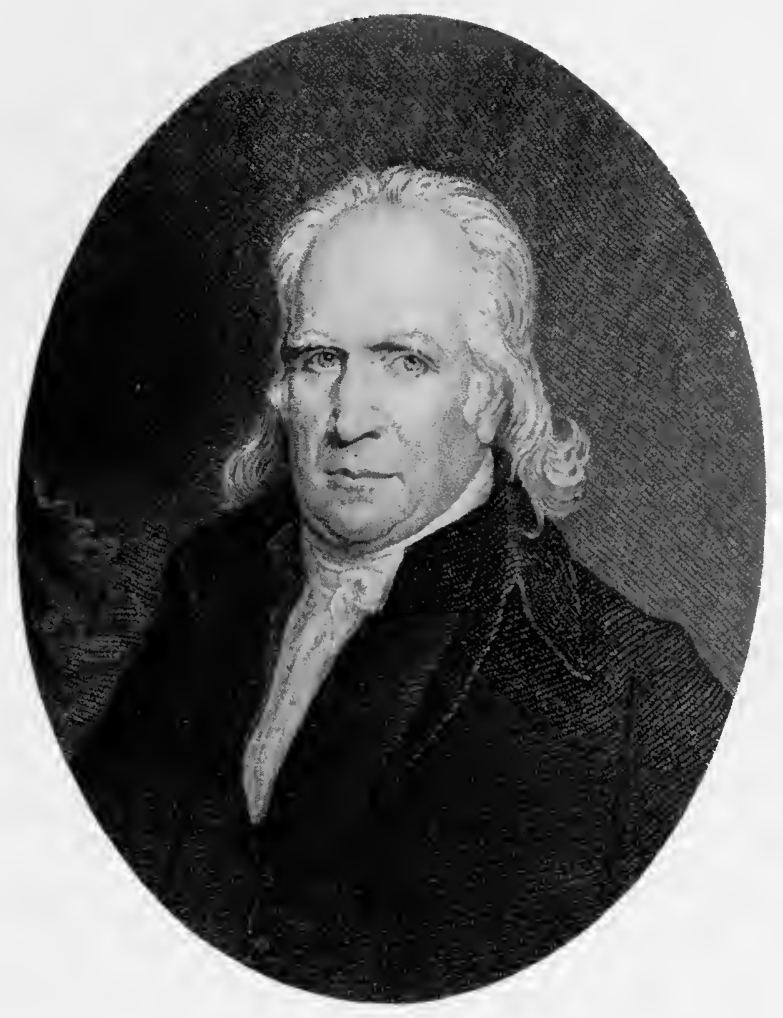

ROBERT R. ROBERTS. 
After his return to Europe he married, but sent over a proposal to take up his permanent residence in America, on condition that the continent should be divided as nearly equally as possible between him and Asbury as superintending bishops. This proposition was not acceptable. On the I6th of November he addressed a letter to the General Conference, in which he said that if they declared that his residence with them would assist to preserve their union, and if they agreed that he should have a full right in the General and Annual Conferences to give his judgment on the making of laws, stationing of preachers, sending out of missionaries, and everything else which as a bishop or superintendent belonged to his office, he would settle his affairs and come to the United States for life. And he added, "You may observe, I do not desire any decisive power. I want no new condition."

This business was settled by a resolution of thanks to Coke, one consenting that he might continue in Europe "until called to the United States by the General Conference, or by all the American conferences respectively"; and another that his name be retained in the minutes after the names of the bishops, with a footnote stating that, " at the request of the British Conference and by consent of this General Conference, he resides in Europe, but is not to exercise the office of superintendent among us until he be recalled as above stated."

Important as was the settlement of this question, another connected with Coke created much more excitement. A remarkable disclosure had been made by the publication of a letter sent by Coke to Bishop White, of the Protestant Episcopal Church, suggesting the union of the Methodists with that body. It was written April 24, I79I. White replied, and certain interviews were held. The bishop kept the correspondence confidential until I 804 , when he 
revealed it to Simon Wilmer, of the Protestant Episcopal Church, and John McClaskey, a member of the Philadelphia Conference of the Methodist Episcopal Church. At a later period White gave a copy of Coke's letter to the Rev. Dr. Kemp, of Maryland, and in a pending diocesan controversy it was published.

Prejudice against Coke was increased by the charge that he initiated this correspondence without consulting Asbury. Much correspondence had been had between Coke and American Methodists in the interval between the publication of his negotiations with White and the assembling of this General Conference. To justify himself he addressed a long letter to the conference. In it he explains that at the time he wrote there were no regular General Conferences, and claims that he proposed the establishment of such bodies; that in the latter end of I 792 he " proposed and obtained that great blessing to the American connection, permanency for General Conferences, to be held at stated times "; that at the time he wrote his letter to White he feared lest the connection would lack stability; that he differed from Bishop Asbury in the matter of the Council, which had come to so disastrous an end; and that he did believe that " under God the connection would be more likely to be saved from convulsions by a union with the old Episcopal Church than in any other way-not by a dereliction of ordination, sacraments, and the Methodist discipline, but by a junction on proper terms." He maintains that he had provided " in the fullest manner, in the indispensably necessary conditions " which he laid down, "for the security and independence of Methodist discipline and places of worship." He states that he did not consult Asbury before he took these steps because he was in the South and inaccessible; that he did not intend to do more than begin a negotiation; and that on the 16 th of the following May he 
did lay the matter before Asbury at New Castle, Del., from which place he embarked for England, and that Asbury, "with that caution which peculiarly characterizes him, gave no decisive opinion on the subject."

In some of the letters which had been sent to Coke an answer had been demanded to a very serious question: "If you did not think that the episcopal ordination of Mr. Asbury was valid, why did you ordain him? Was there not duplicity in this business?" To this he answered:

“( (I) I never, since I could reason on those things, considered the doctrine of the uninterrupted apostolic succession of bishops as at all valid or true.

"(2) I am of our late venerable father Mr. Wesley's opinion that the order of bishops and presbyters is one and the same.

"(3) I believe that the episcopal form of church government is the best in the world when the episcopal power is under due regulations and responsibility.

"(4) I believe that it is well to follow the example of the primitive church, as exemplified in the Word of God, by setting apart persons for great ministerial purposes by the imposition of hands, but especially those who are appointed for offices of the first rank in the church.

"From all I have advanced, you may easily perceive, my dear brethren, that I do not consider the imposition of hands, on the one hand, as essentially necessary for any office in the church; nor do I, on the other hand, think that the repetition of the imposition of hands for the same office, when important circumstances require it, is at all improper.

"If it be granted that my plan of union with the old Episcopal Church was desirable (which now, I think, was not so, though I most sincerely believed it to be so at that time), then if the plan could not have been accomplished 
without a repetition of the imposition of hands for the same office, I did believe, and do now believe, and have no doubt, that the repetition of the imposition of hands would have been perfectly justifiable for the enlargement of the field of action, etc., and would not by any means have invalidated the former consecration or imposition of hands. Therefore I have no doubt but my consecration of Bishop Asbury was perfectly valid, and would have been so even if he had been reconsecrated. I never did apply to the General Convention or any other convention for reconsecration. I never intended that either Bishop Asbury or myself should give up our episcopal office if the junction were to take place; but I should have had no scruple then, nor should I now, if the junction were desirable, to have submitted to, or to submit to, a reimposition of hands in order to accomplish a great object; but I do say again, I do not now believe such a junction desirable."'

As the letter to White was accessible, and several members of the General Conference were well acquainted with the latter, the subject was thoroughly investigated. At the conclusion of the discussion the conference addressed a long letter to Coke, the substance and spirit of which are in the following extract:

"Your two letters [the first related to his official relation to the body] were respectfully received, and had a salutary effect upon our minds. The reasons which you have assigned for some former transactions, and the ingenuous candor which you have manifested in frankly acknowledging and declaring the motives and inducements that led you to those measures, together with your affectionate acknowledgment that in certain cases you were mistaken as to your views of some of the points in question; as likewise your manifest friendship and good will to this connection and your American brethren, and your evident

I Bangs's " History of the Methodist Episcopal Church," vol. ii., pp. 210,211 . 
solicitude to retain a place and standing among us-taking these circumstances collectively, they had a great influence upon some of our minds in removing certain suspicious fears which had been imbibed rather unfavorable to your standing among us.

"You may be assured that we feel an affectionate regard for you, that we gratefully remember your repeated labors of love toward us, and that we sensibly feel our obligations for the services you have rendered us. We hope that no circumstance will ever alienate our Christian affection from you, or yours from us. We wish to maintain and to cultivate a good understanding and brotherly unity with you, and with all our European brethren. In full conference, of near one hundred and thirty members, we entered into a very long conversation, and very serious and solemn debate, upon sundry resolutions which were laid before us relative to your case."

One of the most suggestive situations in ecclesiastical history grew out of this correspondence. Coke had mentioned two difficulties, and in White's reply he said, "I can say of the one and the other that I do not think them insuperable, provided there be a conciliatory disposition on both sides." And, what was still more significant as indicating Bishop White's spirit in this situation, "It is rather to be expected that distinct churches, agreeing in fundamentals, should make mutual sacrifices for a union, than that any church should divide into two bodies without a difference being even alleged to exist in any leading point. For the preventing of this the measures which you propose cannot fail of success unless there be on one side, or on both, a most lamentable deficiency of Christian temper."

In the General Convention of I792 of the Protestant Episcopal Church, propositions for union passed the House 
of Bishops, consisting of four persons-Seabury, White, Provoost, and Madison-but were thrown out in the House of Clerical and Lay Deputies. ${ }^{1}$

Concerning the United States, it is an established fact that such was the spirit of the bishops of the Protestant Episcopal Church in I79 I that a union would have been easy; and subsequently several of the members of the House of Clerical and Lay Deputies which threw out the proposal from the bishops stated had they fully understood the nature of the proposition it would have been approved.

Had such a union been formed it is certain that neither the Protestant Episcopal Church nor American Methodism would have been what it now is, and it is possible that something better than either might exist.

Nine years before the assembling of the General Conference of I 808, Coke sought to effect a virtual union between English Wesleyans and the Church of England, and addressed a letter to the Bishop of London, informing him that he wished to promote the "securing of the great body of Methodists in connection with the late Rev. John Wesley to the Church of England." He stated that they had nearly ninety thousand members, and six times as many regular hearers; that they were friends of the liturgy of the Church of England and its episcopary; but that many of them had a deep prejudice against receiving the Lord's Supper from ministers who frequented card-tables, balls, horse-races, theaters, and other place's of fashionable amusement; that he had tried in vain to show them that the validity of the ordinance does not depend upon the piety, or even the morality, of the ministers. He recounted the different controversies among the Wesleyans, and expressed

1 Bishop White's "Memoirs," pp. 194-199. See footnote on "Evolutions of Episcopacy and Organic Methodism," by T. B. Neely, p. 372. 
his fear that they were deviating to such an extent from the Establishment that in time it would bring about a universal separation.

His scheme was to have a given number of the leading preachers, who should be selected for the purpose by the conference, ordained by the Church of England, and permitted to travel through the connection, administering the sacraments to the societies. He declared his conviction that the numerous societies in America would have been a regular Presbyterian Church had not Wesley and himself taken the steps which they judged it necessary to adopt. Avowing his love for the English church, and asserting that infidelity was moving with such gigantic strides that there ought to be a union of all who could conscientiously unite, he made known to the bishop that men of long standing and great influence in the connection approved the plan, but that these were mostly far advanced in years, informing him also that he had laid the whole plan before the attorney-general, who was a fellowstudent of his at Oxford, and that the latter "greatly approved it."

Coke received from the Bishop of London a courteous acknowledgment of his communication, recognizing the importance of the subject, and stating: "The object you have in view is certainly very desirable; but how far the means you have proposed for attaining it are practicable I cannot at present pretend to judge." The bishop promised to converse upon the subject with the Archbishops of York and Canterbury. The latter wrote to Coke two weeks later, declining to ordain on the recommendation of the conference, and adds that he had conversed with a number of bishops, and all agreed with him that it would be highly improper, and appeals to Coke to "endeavor to bring the people to a better mind." 
Coke's ordination by Wesley had not destroyed his standing as a presbyter in the Church of England. Some years after this, when he had set his heart upon the establishment of a mission in India, being informed that the government contemplated establishing a bishopric there, and finding the Wesleyans not as enthusiastic in the project as himself, he wrote to Lord Liverpool, offering himself as a candidate, promising if appointed "to return most fully into the bosom of the Established Church."

In estimating these proceedings it should be remembered that he lived in a period of bitter controversy on both sides of the Atlantic, and at the time of the secession of O'Kelly had reason for doubting the stability of American Methodism. After Wesley's death the fate of British Methodism was for a considerable time uncertain. It is probable that Coke hoped to succeed Wesley in England; but the English Conference would not brook the idea of the transmission of Wesley's unlimited power, and the Irish Conference, over which Coke had always presided by Wesley's appointment, declined to allow him the presidential chair. But the English Conference showed its esteem for him by making him its secretary, an office which he filled for a number of years.

He continued the most powerful factor in British foreign mission work, while he was technically bishop of the Methodist Episcopal Church; and to him belongs more than to any other the honor of initiating the home mission work of British Methodism.

A discriminating biographer, William Morley Punshon, believes that his life proved that he was "covetous of the responsibility, the unremitting toil, and the untrammeled opportunities of doing good which the bishopric would bring him, rather than of the lawn, the miter, and the 
palace-those post-apostolic appendages to the office which tend only to weight the wings of the 'angels' who have 'the everlasting gospel to preach' in their flight through "the midst of heaven" "; but justly observes that "he would have been a greater statesman if he had had fewer devices, and had cogitated longer on those which his brain conceived. He damaged his own reputation by hasty and injudicious proposals, and gave occasion for suspicion that he was actuated by meaner motives than the noble ones from which he habitually acted."

The conference having decided that the superintendency needed strengthening, it was moved by Roszel that " one person be elected and ordained as joint superintendent or bishop with Asbury"; also by Ostrander, seconded by Soule, that "two be elected and ordained"; and by McClaskey, seconded by Cooper, that "seven be added to the superintendency." The next morning leave to withdraw the motion for seven additional bishops was refused. It was then put to vote and lost; the motion for two additional bishops met the same fate. The original motion was then adopted, whereupon the conference proceeded to the election with one hundred and twenty-eight members present, of whom ninety-five voted for William McKendree, the other votes being divided between Cooper and Lee.

McKendree was famous throughout the West at this time. He was the son of a Virginia planter; at the age of twenty he entered the army of the Revolution, joined a company of volunteers, and became an adjutant, "displaying great energy in procuring supplies to sustain the allied armies of Washington and Count Rochambeau, and was at the battle of Yorktown, when Cornwallis was captured." 
He was baptized and trained in the old colonial church of Virginia, and lived blamelessly, but knew nothing of experimental religion. When the Methodists appeared in his neighborhood he was awakened, and joined the Society, but remained a member several years without obtaining the experience professed by others. Conscious of the inconsistency, he says, "I then peacefully retired from the Society, while my conduct continued to secure their friendship." He remained in this state until thirty years of age, when, under the preaching of the Rev. John Easter, he was fully awakened, and tortured with fears, which gave place to confidence and joy; when he became much concerned for the salvation of those who knew nothing of the gospel hope, although he never imagined that he would preach until his father inquired if the Lord had not called him thereto. He replied, "I cannot tell, for I do not know what being called to preach the gospel implies." Seized with a severe illness, he was visited by the minister under whose preaching he had been aroused, who prayed with singular fervor for his recovery, and that he might "be thrust into the ministry." After hesitation he applied for admission, and was received; in I 790 Asbury ordained him deacon, and the next year elder. Manifesting vigor, zeal, and sense, he was appointed to large circuits, one extending from Chesapeake Bay over the Blue Ridge and Alleghany Mountains, comprehending also a vast region of territory on the Western waters. He accompanied Asbury and Whatcoat to the Western Conference in I 800 , and was appointed to a district embracing the present States of Ohio and Kentucky, and large sections of western Virginia, Illinois, Tennessee, and Mississippi, where he spent eight years, and participated in what has ever since been called "the great revival in Kentucky and Tennessee." 
An issue arose as to the exclusive employment as ministers of men who had received a "liberal education." On this the Presbyterians divided, and a new denomination called "Cumberland" Presbyterians originated in Cumberland County, Tennessee. About the same time the Shakers appeared, and led off some of the Presbyterian ministers into their delusions. "Stoneites," "New Lights," and other half-insane sects were developed. Summers and Paine give interesting details, showing that McKendree was the man for the occasion. He guided the Methodists through their embarrassments without entangling alliances and with comparatively little defection.

Coke was in Europe, and neither Asbury nor Whatcoat could reach the Western Conference for the session of I 804. McKendree presided, and exhibited such ability that after the death of Bishop Whatcoat his name was frequently mentioned for the superintendency. Tradition, however, says that while his abilities, particularly as exhibited in the West, prepared the way, the exciting cause of his election to the episcopacy was a discourse which he delivered on the Sunday before the conference opened. His text was: "For the hurt of the daughter of my people am I hurt; I am black; astonishment hath taken hold on me. Is there no balm in Gilead? is there no physician there? why then is not the health of the daughter of my people recovered?" (Jer. viii. 21, 22). The introduction seemed tame, his sentences disjointed, and his elocution defective. He explained the condition of the human family, and proceeded to analyze the feelings which such a state of things awakened in the souls of God's faithful ambassadors. "But when he came to speak of the blessed effects upon the heart of the balm which God had prepared for the healing of the nations, he carried the whole congregation away with him." At this time he 
was fifty-one years of age, was the first native American elected to the office of bishop, and was ordained by Asbury, assisted by Garrettson, Bruce, Lee, and Ware.

Next to the organization of the Methodist Episcopal Church in 1784 , the introduction of representative government was the most vital change in American Methodism, and remains unparalleled in meaning and influence.

Jesse Lee placed in the hands of Asbury on the 7 th of July, I 79I, "a paper proposing the election of not less than two nor more than four preachers from each conference, to form the General Conference in Baltimore in December, I 792, to be continued annually." 1

In the General Conference of I 800 James Tolleson moved that "Whereas, Much time has been lost, and will always be lost, in the event of a General Conference being continued; and Whereas, The circuits are left without preachers for one, two, or three months, and other great inconveniences attend so many of the preachers leaving their work, and no real advantage arises therefrom; Resolved, That instead of a General Conference we substitute a delegated one."

Tolleson, who possessed high qualities, died of yellow fever a few weeks after the conference adjourned; his memoir in the minutes for 1801 records that as a traveling preacher he labored between eight and nine years, "during which time he filled several important stations with dignity and diligence. $\mathrm{He}$ possessed promising abilities both in gifts and understanding; but, what is of infinitely more importance, he was a man of piety and uniform in his religious deportment."

Although Tolleson's admirably worded resolution was promptly negatived, it soon began to be generally felt that to deposit all power in the entire traveling ministry was 1 "Asbury's Journal," vol. ii., p. 128. 
not wise, neither affording a sufficient guaranty of the unity of the church nor of the security of its government and doctrine. The conferences nearest to the place of meeting always had a much larger representation than those at a greater distance, while the cost to the latter in time, money, and hardship was almost unendurable.

The health of Whatcoat having become impaired, a paper was submitted by Asbury to the Annual Conferences in I 806, beginning with the Baltimore, in favor of calling a General Conference for the purpose of strengthening the episcopacy. It was proposed that it should meet in the city of Baltimore, May, I 807 , consist of seven delegates from each Annual Conference, and have authority to elect one bishop or more, and also to provide for a future delegated General Conference, whose powers should be defined and limited by "constitutional restrictions." 1

This was passed unanimously by the New York Conference, attested and signed by Garrettson, Cooper, and Samuel Coate, and recommended to the other six conferences. The New England concurred by a vote of twenty-eight to fifteen, the Western unanimously, and the South Carolina with her two negative votes. These conferences chose delegates.

Lee says" that " the Virginia Conference at New-Berne, in February, 1807 , refused to take it under consideration, and rejected it as being pointedly in opposition to all the rules of the church. The bishop labored hard to carry the point, but he labored in vain; and the whole business of that dangerous plan was overset by the Virginia Conference. The inventors and defenders of that project might have meant well ; but they certainly erred in judgment."

On the ninth day of the General Conference of 1808 a

1 Bangs, vol. ii., p. 177.

2 " History of the Methodists," p. 345. 
memorial was presented from the New York Conference, showing that the Methodist Episcopal Church was composed of about five hundred traveling and two thousand local preachers, ministering to about one hundred and forty thousand members, "implying congregations who are directly or remotely under the pastoral oversight and ministerial charge amounting in all probability to more than one million of souls." This was preparatory to the consideration of the inconvenience, expense, and loss of time that necessarily resulted from the existing regulations relative to the General Conference. The New York Conference declared its thorough conviction that "a representative or delegated General Conference, composed of a specific number on principles of equal representation from the several Annual Conferences, would be much more conducive to the prosperity and general unity of the whole body than the present indefinite and anomalous body of ministers called together unequally from the various conferences, to the great inconvenience of the ministry and injury of the work of God."

It had been adopted by the New York Conference without a dissenting vote. The New England had unanimously voted to concur, as had the Western, and the South Carolina with the exception of five members.

Asbury called for "the mind of the conference," as to whether any further regulation in the order of the General Conference was necessary. The question was determined in the affirmative.

A committee was formed, by the election of two from each conference, to draw up such regulations as they might consider best, and report to the conference. It was called the "Committee Relative to Regulating and Perpetuating the General Conference."

The members elected were: from the New York Con- 
ference, Ezekiel Cooper and John Wilson; from the New England, George Pickering and Joshua Soule; from the Western, William McKendree and William Burke; from the South Carolina, Joshua Randall and William Phœbus; from the Virginia, Philip Bruce and Jesse Lee; from the Baltimore, Stephen G. Roszel and Nelson Reed; and from the Philadelphia, John McClaskey and Thomas Ware.

They appointed a subcommittee, consisting of Cooper, Soule, and Bruce, to draft a report, to be submitted for approval or modification. It was agreed that each should prepare a paper stating his view of the restrictions necessary, to be presented at a subsequent meeting. Cooper and Soule complied, but Bruce had committed nothing to writing. On comparing the two papers, Bruce fell in with the main points of the one presented by Soule, to which Cooper finally agreed.

At the meeting of the whole committee, which had both plans before them, after some slight changes suggested by the others that of Soule was adopted. ${ }^{1}$

Their report, ${ }^{2}$ which was presented May I6th, elicited much debate, which was suspended for the consideration of the following motion made by Cooper " as preparatory to the minds of the brethren to determine on the subject of the said committee's report":

"Resolved, That in the fifth section of the Discipline, after the question, 'By whom shall the presiding elders be chosen?' the answer shall be: 'Ans. Each Annual Conference respectively, without debate, shall annually choose by ballot its own presiding elders.' '

Debate on this resolution consumed part of Monday afternoon and the greater part of Tuesday and Wednesday. Three times it was moved to close, once to postpone the subject indefinitely, and once until August I 5 th.

1 Charles Elliott's " Life of Bishop Roberts."

2 For report see Appendix II. 
At last a motion to close was carried. On motion of Garrettson it was ordered that the vote be taken by ballot. This being done, the result showed that the resolution was defeated, there being fifty-two yeas and seventy-three nays.

Though Lee had been the first to propose a delegated General Conference, he contended against the entire plan. His principal argument was based upon a doctrine of conference rights. After long discussion, perceiving that the report might be adopted, he moved that the delegates should be sent by seniority instead of by election.

When upon the first resolution the vote was taken by ballot, there were fifty-seven yeas and sixty-four nays. It was soon suspected and finally known that the measure was defeated principally by the votes of the Philadelphia and Baltimore conferences. Asbury was greatly disappointed. The New England delegates prepared to return home, the Western were equally displeased, and many of the members determined to withdraw. Hedding states that all from New England except himself were making arrangements to do so. Paine, in his "Life of McKendree," says that six members from New England and two from the West were going home, but that Asbury and McKendree, aided by Hedding, prevailed upon them to wait for a day.

By all these "fathers" it was considered a crisis in the career of the denomination, and it was ever after the belief of Hedding that had these brethren departed it would have been the last General Conference held.

From Wednesday until the following Monday the excitement continued. The order of events on the latter day was as follows: It was moved and carried that the motion to fix the time and place of the next General 


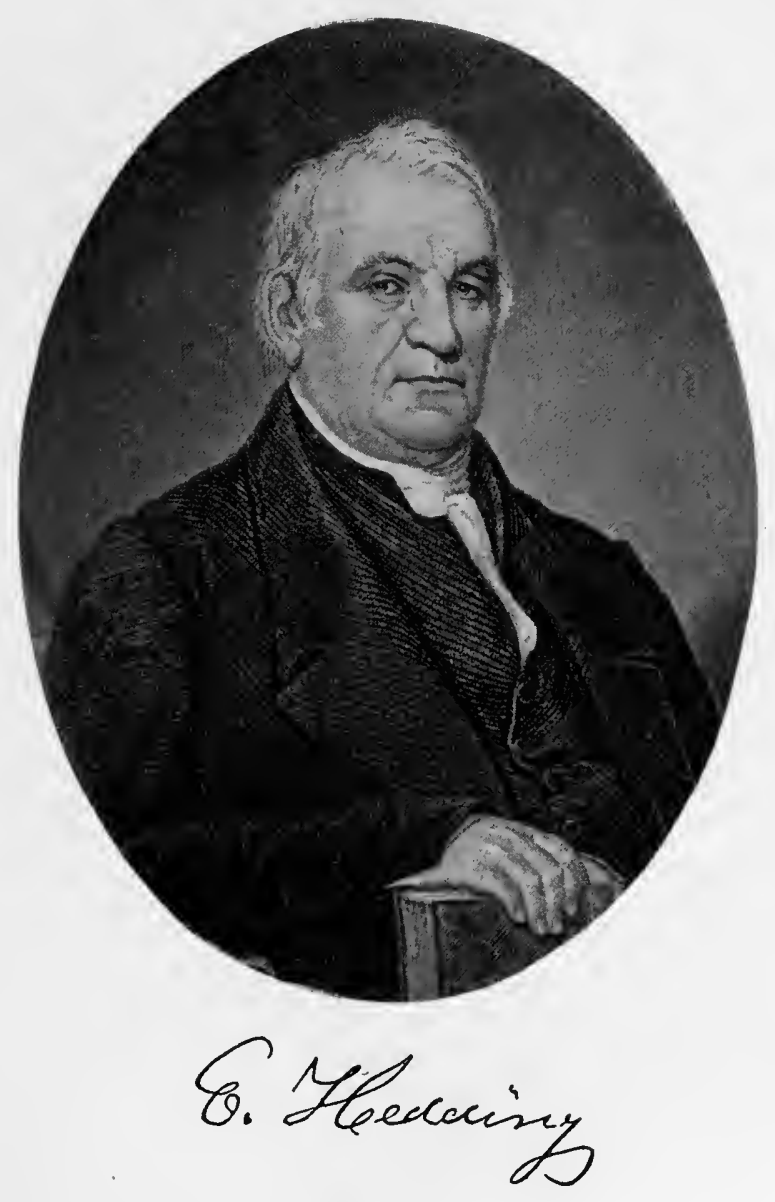



Conference lie over until it was determined who should compose it. This strategic motion was made by Leonard Cassel and seconded by Stephen G. Roszel, and, it having prevailed, Enoch George moved, seconded by Roszel, that "the General Conference shall be composed of one member for every five members of each Annual Conference." Soule then moved, seconded by Pickering, that "each Annual Conference shall have the power of sending their proportionate number of members to the General Conference either by seniority or choice, as they shall think best."

Leroy M. Lee ${ }^{1}$ states that this motion placed Lee between his two doctrines, the independent rights of the conferences and the condition of seniority, neutralizing his opposition. Immediately after this it was decided that the' next General Conference should be held in New York, May I, I8I2. Lee, being now conciliated, seconded the motion of Roszel that " two thirds of the representatives of all the Annual Conferences should be necessary for a quorum in the General Conference."

On Tuesday, May 24th, Lee moved, seconded by Burke, that the General Conference "shall not change or alter any part or rule of our government so as to destroy episcopacy, or to destroy the plan of our itinerant general superintendency." Cooper's proposal to cover this point was, "they shall not take away episcopacy or reduce our ministry to a presbyterial parity."

It was then moved by Roszel, and seconded by Pickering, that "one of the superintendents preside in the General Conference; but, in case of the absence of the superintendent, the conference shall elect a president pro tem." Next it was moved by Roszel, and seconded by Nelson Reed, that "the General Conference shall have full powers to 1 “ Life of Jesse Lee," pp. 442, 443. 
make rules and regulations for our church under the following restrictions:

"The General Conference shall not revoke, alter, or change our Articles of Religion, nor establish any new standards or rules of doctrine contrary to our present existing and established standards of doctrine.

"They shall not allow of more than one representative for every five members of an Annual Conference, nor allow of a less number than one for every seven."

At this point it was moved to appoint a committee of three to modify certain exceptionable expressions in the General Rules. - This was lost, and the third rule, as moved by Roszel, "They shall not revoke or change the 'General Rules of the United Societies,' " was then passed. The next, as follows, was carried:

"They shall not do away the privileges of our ministers or preachers of trial by a committee, and of an appeal; neither shall they do away the privileges of our members of trial before the Society, or by a committee, and of an appeal."

And afterward the following: "They shall not appropriate the produce of the Book Concern or of the Chartered Fund to any purpose other than for the benefit of the traveling, supernumerary, superannuated, and worn-out preachers, their wives, widows, and children," concluding with this provision for alteration of the restrictions:

"Provided, nevertheless, that, upon the joint recommendation of all the Annual Conferences, then a majority of two thirds of the General Conference succeeding shall suffice to alter any of the above restrictions."

The same afternoon it was moved by Ostrander, and seconded by Cooper, that " the general superintendent, with or by the advice of all the Annual Conferences respectively, shall have power to call a General Conference 
if they judge it necessary at any time." On motion of Asbury the following was passed: "That the General Conference shall meet on the first day of May once in four years perpetually, and at such place or places as shall be fixed on by the General Conference from time to time."

Thus by a happy union of the contending forces representative government was introduced under a constitution which guaranteed the doctrines, essential features of the discipline, the rights, privileges, and duties of ministers and members, and, so far as laws could contribute to it, the preservation of the spirit of primitive Methodism, which is the spirit of original Christianity.

The conference by resolutions consented to the appointment of a person to raise a subscription in any part of the connection to assist in defraying " the enormous debt on the new church in Boston." It made a draft of five hundred dollars on the Book Fund to pay the expenses of the more needy preachers back to their circuits; gave Cooper a thousand dollars as extra compensation as booksteward for the first five years; employed J. Wilson as editor and book-steward at a yearly salary of seven hundred and fifty dollars, and Daniel Hitt as assistant editor and book-steward at six hundred dollars. It resolved that no traveling preacher should publish any book or pamphlet without the approbation of the Annual Conference to which he belonged, or of a committee chosen by them; and substituted the word "allowance" for "salary" wherever it occurred in the Discipline.

On motion of Asbury it passed the following portentous resolution :

"That there be one thousand.Forms of Discipline prepared for the use of the South Carolina Conference, in which the section and rule on slavery be left out."

The fact that Bangs does not refer to this subject has 
been noticed by several writers. Just before this a motion to strike out the whole section in the Discipline respecting slavery was lost, and just after it Roszel moved, seconded by Ware, that the first two paragraphs of the section on slavery be retained in the Discipline, and that the General Conference authorize each Annual Conference to frame its own regulations relative to buying and selling slaves.

It has been said by a writer that such measures tempt us to blush at every aspect in which they present the legislative acumen of our fathers. Should it not the rather be said that they show to what lengths legislators of benevolent minds may go to promote peace, and emphasize the oft-repeated teaching of God's Word that peace may be purchased at a price too dear?

As Lee represented the opposition at the General Conference of 1808 , and as his "History of the Methodists" was copyrighted in December of that year, his testimony as to the reception of the work of that body, and as to the necessity of establishing representation, is valuable:

"Our connection having spread very extensively, and the number of our preachers being much larger than formerly, it was thought best to make some new regulations about our General Conference in future, and the foregoing regulations were agreed to, by which means each part of the connection would have a proportionable number of preachers in the General Conference. The Baltimore and Philadelphia conferences will no longer include more than half the members of the General Conference. . . . There was a good deal of peace and union among the preachers at that General Conference, and there were one hundred and thirty traveling preachers who were members of that conference. Mr. McKendree had been a traveling preacher just twenty years when he was ordained a bishop. Most 
of the preachers returned from that conference well satisfied with what was done while we were together."

The religious influence of this conference was as valuable to the denomination as was its work in legislation. On Sunday, the 8 th, Pickering preached in the market-house, and three others exhorted afterward: later McKendree delivered his great sermon; in the afternoon Mead preached at Oldtown, while Asbury gave the opening sermon of a new chapel. Three times a day there was preaching in one of the churches, and every evening in the four others, all these services resulting in conversions. On the following Sunday, McKendree preached at 7 A.M., Asbury at ten, Gruber in German at three o'clock in Otterbein's church, McKendree at five, and McClaskey in the evening. On the last Sunday of the conference Pickering was heard at six, Coate at seven, Gruber at three to the colored people, Cooper at five, and Lee in the evening. Henry Boehm, who gives these particulars, says that there was a great deal more preaching - that he has simply named the men he heard.1

1 " Reminiscences, Historical and Biographical, of Sixty-four Years in the Ministry," by Henry Boehm, edited by J. B. Wakeley (New York, I865). 


\section{CHAPTER XIV.}

\section{EVOLUTION UNDER A CONSTITUTION.}

CLOSE attention to detail was necessary so long as the Methodist Episcopal Church was governed by assemblies with power to repeal any act of their predecessors, and even, by a vote of a majority, disband the church, or transform it into something wholly unlike itself. Hereafter must chiefly be noted salient steps in the march of an army thoroughly drilled and ever ready for the charge.

Early in I8I I, after various disputes between England and this country, there was an encounter between an American and an English vessel, and an American court of inquiry decided that the first shot was fired by the English, which gave rise to an apprehension of serious complications with Great Britain. This resulted in an extended discussion, and an increase of the army by the addition of twenty-five thousand men. The agitation was not favorable to the spread of Methodism, but considerable attention was given to the erection of churches.

The General Conference of 18 2 met in the city of New York, with fifteen delegates from the Baltimore Conference, fourteen from the Philadelphia, thirteen from the New York, and the same number from the Western, eleven from the Virginia, nine each from the New England and the South Carolina, and six from the Genesee.

A question arose respecting some of the delegates from 408 
New England. Three reserves had been elected to "succeed and take the place in case of the failure of any of the first chosen delegates." By a vote of fiftysix against twenty-two, it was decided that they should be seated.

The conference decided by a majority of nearly two thirds that it had power to resolve itself into a committee of the whole.

McKendree presented his views in writing, an act without precedent. Asbury immediately arose, and in substance thus addressed him: "I have something to say to you before the conference." McKendree rose, and they stood face to face. Then said Asbury, "This is a new thing. I never did business in this way, and why is this new thing introduced?" McKendree replied, "You are our father; we are your sons. You never have had need of it. I am only a brother, and have need of it."

The various parts of this address were referred to special committees, the one on the episcopacy being elected by ballot.

Lee moved that "the members of the next General Conference go by seniority, and that the supernumerary and superannuated preachers shall not be included among the senior preachers; also that one for every six members shall go to the next General Conference, and in case there are two or more preachers of equal standing, then the first-named shall have the preference, and should any of the above-named preachers fail by sickness or otherwise to attend the General Conference, then the next senior preacher shall go in his place."

This was an important series of motions, and raised the question at once of the powers of the delegated conference under the rules formed "for the perpetuation and regulation of General Conferences" by that of 1808 . The first 
proposition also involved the question upon which Lee had been outgeneraled in the preceding conference. On Friday, the questions being divided, both motions were lost.

James Axley, a member from the Western Conference, moved that "no stationed or local preacher shall retail spirituous or malt liquors without forfeiting his ministerial character among us." This motion was defeated; but in the pastoral address was inserted: "It is with regret that we have seen the use of ardent spirits, dram-drinking, and so forth, so common among the Methodists. We have endeavored to suppress the practice by our example, but it is necessary that we add precept to example; and we really think it not consistent with the character of a Christian to be immersed in the practice of distilling or retailing an article so destructive to the morals of society, and we do most earnestly recommend the Annual Conferences and our people to join with us in making a firm and constant stand against an evil which has ruined thousands both in time and eternity."

This shows that those who have inferred that the conference was in sympathy with the use of spirituous or malt liquors because it declined to pass the motion made by Axley are not warranted in the conclusion. Since the practice had grown up gradually, it was deemed by the majority improper to pass a rule at that time.

John Sale moved a resolution to prevent the preachers and private members from buying or holding lottery tickets, or having anything to do with them; but the conference was divided in sentiment upon the subject, and the motion was postponed until May I, I8I6. Lotteries were then considered a proper method of raising money for churches.

The most important debate was upon a proposition to 


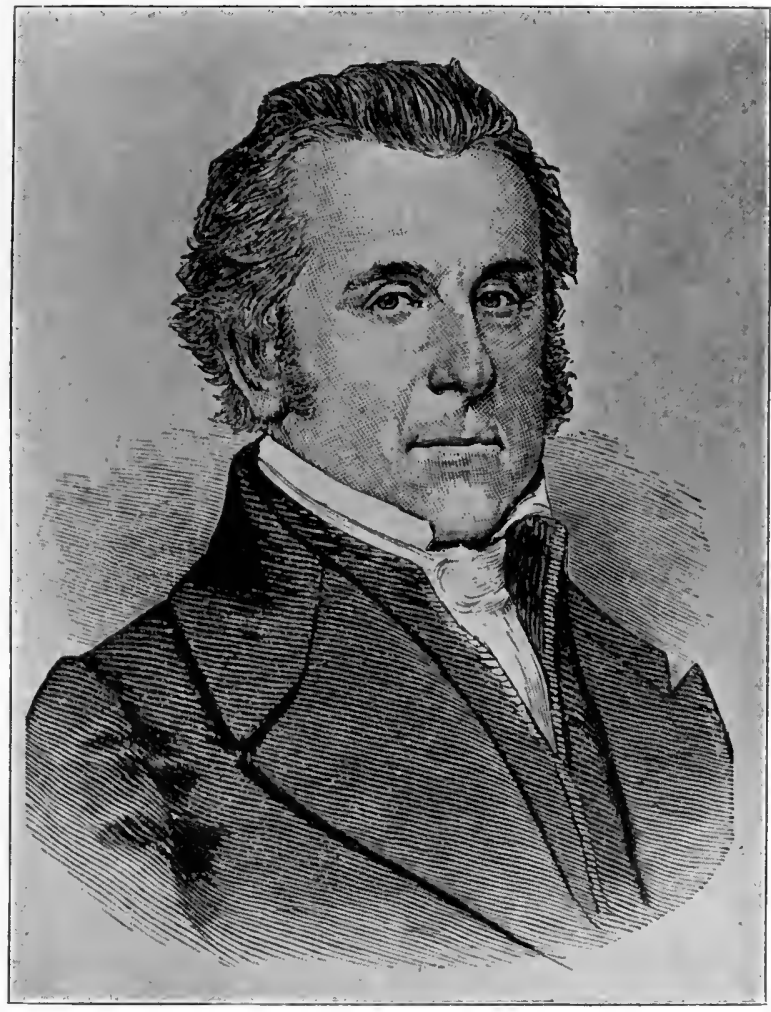

NICHOLAS SNETHEN. 

legalize the election of presiding elders by the Annual Conferences-a subject which had been an occasion of controversy at almost every General Conference. Laban Clark, of New England, offered a resolution in favor of it, to which Nicholas Snethen moved an amendment "that the bishops shall have power to nominate presiding elders, and if the first nomination is not ratified by a majority of the Annual Conference, the bishop shall proceed to nominate until a choice is made; and in all cases each nomination shall be determined separately by ballot, without debate." While this was pending, it was moved that the subject lie on the table until the bishops gave their opinion. This was lost by a vote of forty-one for and fortytwo against. On the decision of the question, eighty-two votes were cast, of which thirty-nine were in favor and forty-three against the election of presiding elders. The delegates of the Philadelphia, New York, and Genesee conferences, thirty-three in number, were sent under instructions to vote for it, and they did so; which shows that four fifths of the other five conferences were against it. Among the advocates were Ware, Garrettson, Cooper, Lee, Asa Shinn, and Nicholas Snethen. ${ }^{1}$

To McKendree is due the cabinet, so called. Asbury would never permit the presiding elders to counsel him in stationing preachers. He knew them all, and declared that he did not wish his judgment confused by the prejudices and prepossessions of others; for he had "no ends to gain"; some of them might have. Asbury, without success, urged McKendree to pursue the same course. The original plan of these two bishops was to attend the conferences together, as Asbury and Coke had done, and, more recently, Asbury and Whatcoat.

Many of the influential members of the conference were 1 “General Conference Journals," vol. i., p. II5. 
convinced of the necessity of a denominational periodical. The "Methodist Magazine" was started in I 789 , but suspended the year following. For reasons not fully understood at the present day, so many were opposed to it that a vote directing the agents to resume the publication of the magazine passed by a bare majority.

It was decided by ballot to hold the next General Conference in Baltimore. Early the next month Congress passed a bill, which was signed by the President, declaring war with Great Britain. During three years the war was waged on land and sea with varying fortunes, until the last battle, which took place at New Orleans on the 8 th of January, 1815 . The effect of this conflict on the relations between the Canadas and the United States was exceedingly unhappy. Bangs, appointed presiding elder in the lower province, was to have charge also of Montreal, but by the consent of the bishops gave up his journey when he had reached Lansingburg, N. Y., and remained in the United States; and only one preacher, Thomas Burch, who volunteered for Canada, succeeded in reaching it. The ministers in Upper Canada belonged to the Genesee Conference, but were unable to attend its session, as all friendly intercourse between the two countries was suspended.

A sect known as Reformed Methodists arose in 1813 , led by Pliny Brett, who was refused admittance into full connection in the New England Conference. This party claimed peculiar attainments in holiness, and was the means of destroying one or two large and several small societies, particularly on Cape Cod and in Vermont.

Under the auspices of the British Wesleyan connection, Dr. Coke, accompanied by six missionaries, embarked on the roth of December, I8I 3 for Ceylon. On the morning of the 5th of May, I814, he was discovered lifeless in his cabin, and it was the opinion of the ship's surgeon that 
death was occasioned by a stroke of apoplexy, "to which, from the make of his body and the nature of his constitution, he appeared to have been somewhat predisposed." 1

One of the missionaries, in the presence of the soldiers, the crew, and the passengers, read the burial service over the body of this man, venerable with age, learning, and services to the Christian church; and, as the sun was sinking, "the casket and its precious contents were cast into the Indian Ocean, to await the fulfillment of the promise, "the sea shall give up its dead.'"

Memorial sermons were preached in the principal Methodist churches and chapels of the world. Wherever Asbury went he delivered such to the conferences, pronouncing Coke a man "of blessed mind and will; of the third branch of Oxonian Methodists; a gentleman, a scholar, and a bishop to us; and, as a minister of Christ, in zeal, in labors, and in services the greatest man in the last century." This eulogium is merited; but had he spoken in such exalted terms of his judgment, it would have been an exaggeration.

As the war continued Methodism in Canada suffered exceedingly. The circuits in Upper Canada were manned, but those in Montreal, St. Francis, and Ottawa were without regular supplies. The church in Quebec had no regular pastor for two years of the struggle, but a Methodist surgeon in a British regiment preached there efficiently, and when his regiment was removed a local preacher was developed.

When peace was declared the membership in Canada had been reduced to little more than half the number at the beginning of hostilities. The Genesee Conference resumed care of the country. William Case was made presiding elder of the Upper Canada district, and Henry

1 Drew's " Life of Coke." 
Ryan of the Lower Canada. The British Conference, however, sent over three missionaries for Montreal and Quebec.

The increase in 1813 was 18,950 in members, but the following year exhibited a decrease of 3178 ; the number of traveling preachers was decreased by one. The increase of members in 1815 was but 36 , and of preachers I 7 ; justifying Wesley's aphorism that "war is always a foe to true religion."

Asbury left Albany, N. Y., on the 27th of May, I815, to attend the New England Conference, reaching Boston eleven days later greatly exhausted, so that during the session he was confined to his room. By great effort he was able to ordain twelve deacons and twelve elders, but resigned the presidential chair to George Pickering. With indomitable courage he had planned a tour of sixteen hundred miles, but weakness compelled him to reduce it " to a straight ride of three hundred and eighty miles to New York."

This led him through Ashgrove, where he preached in the chapel. The place was named by Ashton, companion of Robert Williams, and the society had been formed by Philip Embury, who had removed from New York in I 769, and for six years had been chaplain and class-leader of the few pious souls who formed the settlement. Injured while mowing in his field, he had died in 1775, and Asbury always spoke tenderly of that little society.

After preaching in New York he went to Wilmington, where he found Judge Bassett helpless from a second stroke of paralysis. Thence he traveled to Ohio, and, although ill, presided at the Ohio Conference. McKendree met him here, and accompanied him to Cincinnati. Later he attended the Tennessee Conference and preached on the death of Coke, recording in his "Journal" these 
pathetic words: "My eyes fail. I will resign the stations to Bishop McKendree. I will take away my feet. It is the fifty-fifth year of ministry, and forty-fifth year of labor in America. My mind enjoys great peace and divine consolation."

This was the last conference he attended, and in December he made the last entry in his "Journal." His doubts and fears were gone, and he wrote: "My consolations are great. I live in God from moment to moment."

On the 24th of March, hoping to attend the General Conference, which was to meet in Baltimore, he started northward, reaching Richmond, Va. There he preached his last sermon. Not being strong enough to walk, even with the support of his friends, he was carried into the church in their arms. His text was, "For he will finish the work, and cut it short in righteousness: because a short work will the Lord make upon the earth."

Accompanied by the Rev. John Wesley Bond, he journeyed until the 29th of March, when he reached the house of Mr. Arnold in Spottsylvania, eighteen miles from Fredericksburg; and there on Sunday, March 3I, I816, he died, testifying by expressive gestures to his love, hope, and peace, when he could no longer speak. ${ }^{1}$

Can his career be paralleled? "In his American ministry alone he preached sixteen thousand five hundred sermons, ordained more than four thousand preachers, traveled on horseback or in carriages two hundred and seventy thousand miles." Well does Stevens say that, with "Wesley, Whitefield, and Coke, he ranks as one of the four greatest representative men of the Methodist movement." So fine was his discrimination that his estimate of men was almost infallible, and such his self-restraint that one could

1 " Bishop Asbury: A Bingraphical Study for Christian Workers," by the Rev. F. W. Briggs, M.A. (Wesleyan Conference Office, London, England). 
never discern his thoughts before he was disposed to disclose them.

Contentions between the white and the colored Methodists of Philadelphia increased to such an extent that John Emory issued a circular letter to the colored people of Bethel Church stating that the white preachers could no longer maintain pastoral responsibility over them. On account of this "they considered themselves disowned by the Methodists." A meeting-house was fitted up not far from Bethel, and an invitation given to all colored people who desired to be Methodists to attend there. But this plan not succeeding, in I 8 I 4 Robert R. Roberts, an elder and pastor of St. George's Church, insisted upon preaching to and taking pastoral charge of them, claiming the right to do so under a contract made between the members of Bethel Church and the Methodists at the time Asbury ordained Allen a deacon. Being advised that he ought to make terms with the trustees, he replied that " he did not come to consult with Richard Allen or the trustees, but to notify the congregation that on the next Sabbath he would be present and take charge." He was informed that he could not be allowed to preach; nevertheless at the appointed time he came. The trustees, having taken legal counsel, had placed their own preacher in the pulpit, and so disposed the congregation that it was impossible for Roberts to reach it, and after some debate he departed.

The next year his successor, Robert Burch, pursued a similar course with a like result, in consequence of which he applied to the Supreme Court for a writ of mandamus. The application was decided in favor of Bethel Church.

The colored people of that society and those of their own race who sympathized with them organized them- 


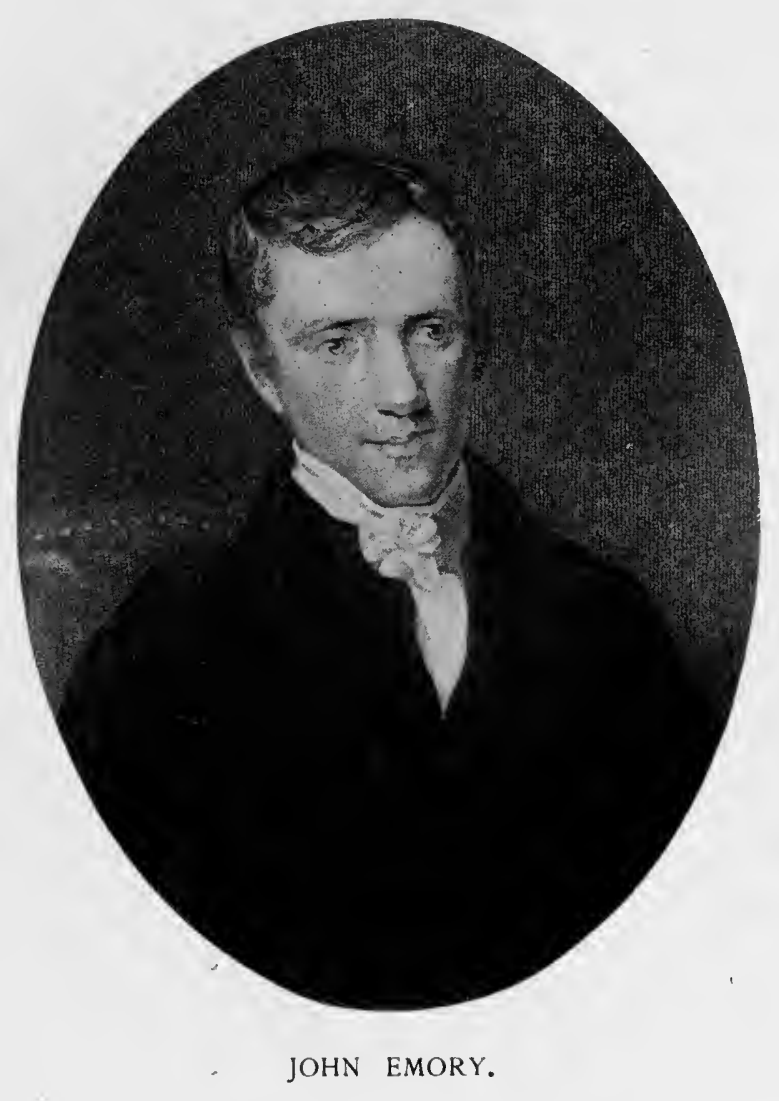


selves in 1816 into an independent body, adopting as their standards the doctrines of the Methodist Episcopal Church, and, with very few modifications, its Form of Discipline. They held their first General Conference in April, I8I6, and Richard Allen, previously ordained an elder, was elected to the office of bishop, and was consecrated by prayer and the imposition of the hands of five colored local elders, one of whom, Absalom Jones, was a priest of the Protestant Episcopal Church. Thus arose the African Methodist Episcopal Church.

Peter Spencer, a colored man in Wilmington, Del., had been set apart in 18 13 by election, and the laying on of hands of three lay elders who were chosen to that office for a special purpose, thus becoming the germ of the Union American Methodist Episcopal Church.

News of the establishment of these denominations stirred up considerable uneasiness among the colored congregations of the Methodist Episcopal Church in different parts of the country, especially in New York. The colored Methodists of that city had applied for the ordination as elders of some of their local preachers, but the Methodist Episcopal Church meted out to them in substance the same treatment which the early Methodists had received from the English church, a kind of Fabian policy of inactivity. The aggressiveness of Peter Spencer and Allen, espec ally of the latter, compelled the Zion people in New York to renew their efforts to obtain ordination by the bishops. ${ }^{1}$

In rebuilding John Street Church, in 1817 , the trustees and other members became involved in controversy, and the contest growing bitter, William M. Stillwell, a traveling preacher, three trustees, and three hundred members

1 "One Hundred Years of the African Methodist Episcopal Zion Church," by Bishop J. IV. Hood (A. M. E. Zion Book Concern, New York City), p. 62, 
of the society seceded. Various local preachers and members affiliated with them, and the sect became known as Stillwellites. For a time it increased rapidly; but soon it was seen that it had no distinctive principles and could supply no demand; and most of the seceders returned to the Methodist Episcopal Church "convinced that it is easier to destroy a good church than to make a better one." 1 Those who did not return renounced the itinerancy, and formed a Congregational church, of which Stillwell was pastor. In a few years, however, it utterly disappeared.

The minister who was last appointed from the New York Conference to Zion Colored Church in New York was among the seceders. He was allowed to finish his year, not as an appointee of the bishop, but as called by the church. They availed themselves of the help of Dr. James Covel, Sylvester Hutchinson, and William M. Stillwell, who set apart Abraham Thompson, James Varick, and Leven Smith as elders, they having been previously ordained deacons. Thus originated the African Methodist Episcopal Zion Church.

The General Conference of I 816 met on the first day of May, and consisted of sixteen delegates from the New York Conference, fourteen each from the South Carolina, the Baltimore, and the Philadelphia, twelve from the New England, ten each from the Genesee and the Virginia, nine from the Ohio, and six from the Tennessee. Asbury had prepared an address, which was solemnly read to the conference by the secretary, as was one from McKendree. Besides this communication Bishop Asbury, August 5, I813, prepared a remarkable valedictory epistle "to William McKendree, Bishop of the Methodist Episcopal Church." Enoch George and Robert Richford Roberts were elected 


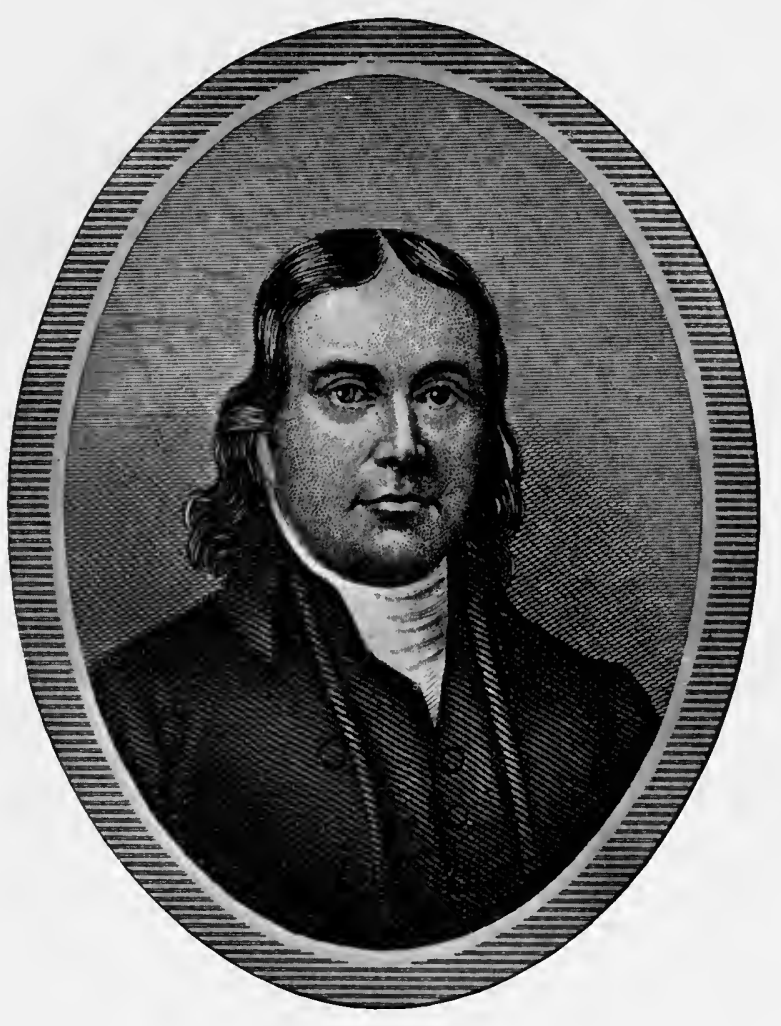

ENOCH GEORGE. 
bishops on the I4th of May, the former having fifty-seven and the latter fifty-five votes. George was a native of Virginia, trained in a family where religion was merely a form, notwithstanding it was within the parish of Devereux Jarratt, that "Methodist before Methodism." On removing to another part of the State the family became acquainted with Methodism. The first preacher whom they heard was John Easter, who had produced so profound an impression upon McKendree. When George attended the meeting he was at once convicted, but became so terrorstricken that he determined to be seen among them no more. On reflection he came to a better mind, was converted, and being called to the ministry in 1789 , began to travel with Cox, at that time book-steward. The latter introduced him to Asbury, who admitted him to the conference on trial in 1790 . Six years later he was presiding elder of the Charleston district. The next year, compelled by illness to refrain from labor, he located, becoming a teacher. After some years of retirement he joined the Baltimore Conference, filling important positions effectively, and for the four years preceding this General Conference had been presiding elder of the Potomac district. Unction in preaching, good judgment, humility, and dignity accounted for his election. ${ }^{1}$

Roberts was born in Maryland, in 1778 , of Welsh and Irish ancestors, and was converted when but fourteen; was licensed as an exhorter in 1800 , and entered the ministry in 1802 under the guidance of James Quinn, beginning his ministry on Carlisle circuit, having his residence at York. After a more than usually eventful and successful probation he was admitted in 1804 into full connection; Coke and Asbury presiding. He knew the foremost men of Methodism, and attended the General Con-

1 Sherman's " Life of George," in " Lives of Methodist Bishops." 
ference of 1808 , where he voted for an elective presiding eldership, afterward, however, changing his opinions. $\mathrm{He}$ was appointed in I8I I to Alexandria, Va., frequently exchanging pulpits with the Protestant Episcopal minister; here became intimate with President Madison, and whenever he visited him, closed the interview with the President and his wife with prayer.

Joseph Samson, who had been expelled from the Philadelphia Annual Conference for denying the divinity of Christ, and had appealed from the decision, appeared, admitted the correctness of the journal, made a statement, and retired. The constitutionality of the proceedings of the Philadelphia Conference was called in question; but the decision was affirmed.

Samuel Merwin moved a resolution amending the Discipline so as to secure the election of presiding elders by Annual Conferences on the nomination of bishops. The conference went into a committee of the whole, and after several meetings voted against the proposal by a majority of eighteen. This being reported to the conference, debate was resumed on the subject. An attempt was made to divide the motion, which the chair declared to be out of order, and an appeal was taken. By a majority of three the decision was sustained. The Committee on Ways and Means made it the duty of the bishop or bishops, or a committee which they might appoint in each conference, to order a course of reading and study for candidates for the ministry, and to provide for their examination.

The relation of the Methodism of the United States to that of Canada being under consideration, an elaborate communication was received from the British Methodist Missionary Society, relating the facts concerning the sending of missionaries to Montreal, and that misunderstandings had arisen between these and Henry Ryan, the pre- 
siding elder for Lower Canada. The missionaries had reported to the British Conference what they had done, and Ryan had addressed to it a letter of complaint. The committee expressed the hope that the business might be settled amicably.

The conference in response recited that its committee had had several friendly interviews with the Canadian delegates, Black and Bennett, who had been invited to seats in the body, and gave the situation from its point of view; but, under all the circumstances, and especially considering the contiguity of the provinces to the western and northern parts of the United States, the General Conference resolved that "we cannot consistently with our duty to the societies of our charge in the Canadas give up any part of them or any of our chapels in those provinces to the superintendence of the British connection."

Joshua Soule was elected editor and general booksteward, and Thomas Mason associated with him.

James Axley brought forward a motion similar to that which was defeated four years before, that no preacher should distill or retail spirituous liquors without forfeiting his license. An attempt was made to amend this by adding "that every prudent means be used by our Annual and Quarterly-meeting Conferences to discourage the distilling or retailing of spirituous liquors among our people, and especially among our preachers." This was obviously unpopular and immediately withdrawn, and under the previous question Axley's motion was passed.

To slavery the conference referred as an evil past remedy; and, after striking out some neglected recommendations, enacted that " no slave-holder shall be eligible to any official station in our church hereafter, where the laws of the State in which he lives will admit of emancipation, and permit the liberated slave to enjoy freedom." 
Two new conferences, the Mississippi and the Missouri, were added. During the debates it had been suggested that a specified district of country should be apportioned to each bishop; the majority, however, preferred to leave these things to be regulated by the bishops themselves, recommending that each bishop visit all the conferences at least once in four years.

Asbury, in I808, had proposed that one thousand dollars be appropriated from the Book Concern for the printing of religious tracts to be given away, and increasing use had been made of them. Holy women of the Methodist Episcopal Church in the city of New York in I 8 I 7 formed a Tract Society; but much research has failed to disclose any of their names, although this organization became the nucleus of the denominational Tract Society.

Early Methodism, in America no less than in Europe, was aided powerfully by its discreet, heroic, and devout women, of the spirit, but not having the special opportunity, of Barbara Heck. Of the seven or eight members of Mr. Strawbridge's class, probably the first formed in the United States, the names of six are known, and four were women. The first converts made under Strawbridge's preaching appear to have been John Evans and his daughter, Mrs. Sarah Porter. In I856 this lady gave an account of her father's conversion, in which she stated that while he was at Mr. Strawbridge's, assisting in doing the farm work, Strawbridge being absent on a preachingtour, " Mrs. Strawbridge introduced the subject of experimental religion, which made such an impression on his mind as to result in his subsequent conversion to God." 1 Mary Wilmer was the second female class-leader in Philadelphia. Mrs. Judge White led her husband to become a Methodist, and it was she who exhorted Benjamin Abbott

1 Stevens. 
to give himself wholly to God. Mrs. Bassett, of Delaware, "gave her influence, means, and bright example of holiness to Methodism," as did Mrs. Prudence Gough, of Perry Hall.

On account of the privacy of their lives the names of Methodist women rarely appear in history, yet the beauty of the Lord was upon them, and-like those of these selfdenying founders of the Tract Society in American Methodism-the works of their hands are "established."

During the session of the General Conference the remains of Asbury were disinterred and borne to Baltimore, where, after a sermon from McKendree, followed by a procession including all the General Conference and hundreds of other clergymen from the city and neighboring churches, they were deposited beneath the altar of Eutaw Street Church.

Less than four months after the adjournment of the conference, Jesse Lee closed his career under circumstances similar to those surrounding Whitefield in his last hours. He was perhaps the most popular in the modern sense of the term, and one of the most effective in any sense, of early American Methodist preachers. His last station was in Annapolis, the capital of Maryland. During his services there he attended a camp-meeting near Hillsboro, preaching twice, and in the evening of the day in which his last sermon was delivered was seized with a congestive chill from which he never rallied. For a short time he suffered from depression, but for several days preceding his death was exalted by holy joy. He was the founder of Methodism in New England, the first historian of the church, and chaplain of the House of Representatives at Washington from I 809 to I 8 I 5 , when he resigned to satisfy the scruples of some of his brethren, who thought it "too near an approach to secular work for a man in the office of a Methodist preacher." 
Asbury early chose him for the episcopacy, and several times it seemed likely he would be elected to it, but his manly independence and firmness of opinion in times of party strife were made the occasions of his defeat. In public services he might fairly be ranked next to Asbury. ${ }^{1}$

The Wesleyan Academy was established at New Market, N. H., in 1818 , by New England Methodist preachers. A similar academy, known as the Wesleyan Seminary, was founded in 1819 in New York City under the patronage of the New York Conference. Dr. Samuel K. Jennings, aided by several citizens of Baltimore, founded a literary institution in that city to be known as Asbury College, but it did not succeed.

The general Missionary Society was formed in April, I 8 I9, under the name of the Missionary and Bible Society of the Methodist Episcopal Church in America, the place of the first meeting being the Forsyth Street Church, in the city of New York, where a constitution was read and adopted. The names of the ministers present at the time the committee was appointed for its formation were Freeborn Garrettson, Joshua Soule, Samuel Merwin, Nathan Bangs, Laban Clark, Thomas Mason, Seth Crowell, Samuel Howe, and Thomas Thorpe. Garrettson, Clark, and Bangs were the committee who prepared the constitution. McKendree, George, Roberts, and Nathan Bangs were respectively president, first, second, and third vice-president. Soule was treasurer, Mason corresponding secretary. The managers were well-known laymen. The entire receipts for the first year were $\$ 823.64$, and the first anniversary was held April I 7, I 820 .

About the same time a missionary society was formed within the bounds of the Philadelphia Conference.

The "Methodist Magazine" was permanently estab-

1 Stevens's "History of the Methodist Episcopal Church," vol. iv., pp. $510,51 \mathrm{I}$. 
Doshua Soule 

lished in 1818 , under the editorship of Soule, and not less than ten thousand subscribers were obtained the first year.

The General Conference, to which the eleven conferences had elected eighty-nine delegates, assembled, with all the bishops present, in Baltimore May I, 1820 .

In view of the increase of seminaries and the need of religious influence and continuity of method, the bishops were authorized to appoint principals from among the traveling preachers for a longer period than two years.

Difficulties in Canada had increased, and it became necessary to appoint a formal delegate to the British Conference for the purpose of negotiation.

The hymn-book prepared by the Book Concern, consisting chiefly of hymns by John and Charles Wesley, was approved by the conference. District conferences were established.

The constitutionality of the Annual Conferences locating traveling preachers without their consent was discussed, but left unsettled.

Joshua Soule was elected a bishop, receiving forty-seven of the eighty-eight votes cast, and Nathan Bangs thirtyeight.

The conference recommended the Annual Conferences to establish, as soon as practicable, literary institutions under their own control, leaving the manner to their judgment; and it made it the special duty of the episcopacy to use their influence to carry this resolution into effect by urging it upon each of the conferences.

A protest was recorded against the rental of pews in the churches, and it was ordered that the erection of no house of worship should be commenced until three quarters of the money necessary to complete the building was in hand or subscribed.

The burning question was the election of presiding 
elders. The conference resolved, first, "That whenever, in any Annual Conference, there shall be a vacancy or vacancies in the office of presiding elder, in consequence of his period of service of four years having expired, or the bishop wishing to remove any presiding elder, or by death, resignation, or otherwise, the bishop or president of the conference, having ascertained the number wanted from any of these causes, shall nominate three times the number, out of which the conference shall elect by ballot, without debate, the number wanted; Provided, when there is more than one wanted, not more than three at a time shall be nominated, nor more than one at a time elected; Provided, also, that in case of vacancy or vacancies in the interval of any Annual Conference, the bishop shall have authority to fill the said vacancy or vacancies until the ensuing Annual Conference."

Second: "That the presiding elders be, and hereby are, made the advisory counsel of the bishop or president of the conference in stationing the preachers."

This was signed by Cooper, Roszel, Bangs, Wells, Emory, and Capers. The first resolution was passed by a vote of sixty-one to twenty-five without change, and the second received a minor amendment by the consent of the committee and was then adopted.

Some days later Soule, bishop elect, addressed a letter to the episcopacy, which was publicly read, stating that if ordained he would not hold himself bound to be governed by the resolutions of the conference relative to the nomination and election of presiding elders, as he did not consider them constitutional. It was moved to reconsider them. The discussion continued until the time fixed for the ordination of Soule, and the motion to reconsider was defeated by a tie, the vote being by ballot. The next day Soule presented his resignation of the office of bishop. 
A day later it was moved that the resolution concerning the nomination and election of presiding elders be suspended until the next General Conference, and that the General Superintendents be instructed to act in the interval under the old rule. A point was made that this resolution was not in order; the chair held that it was, and an appeal being taken, its decision was sustained. At the afternoon session Soule was requested to withdraw his resignation, but he declined to do so and it was accepted.

Pending the determination of the question, the constitutionality of the resolutions was discussed by the bishops in private. It was learned that Roberts was of the opinion that the resolutions infringed the constitution; George was silent, but McKendree emphatically pronounced them unconstitutional, and addressed a letter to the General Conference to that effect, and affirming that, as they were without proper authority and form, he considered himself under no obligation to enforce them, or to enjoin upon others to do so.

A proposition, signed by Roszel and Finley, for a new law advising the Annual Conferences so to alter the constitution as to give the bishops a qualified veto power when they should judge an act of the General Conference unconstitutional, was carried. Unsuccessful efforts were made to elect another superintendent. Nathan Bangs was made editor and general book-steward, and Thomas Mason assistant book-steward. The conference having decided to elect an agent for the Book Concern in Cincinnati, Martin Ruter was chosen on the second ballot. Soule, Bangs, and Ostrander were appointed a committee "to assist the episcopacy to revise the Form of Discipline, and conform it to the regulations and resolutions of this conference." 


\section{CHAPTER XV.}

\section{CRITICAL DISCORDS AND COMPREHENSIVE ENTERPRISES.}

MCKENDREE addressed a letter to the different conferences immediately after the adjournment, protesting against the suspended resolutions as unconstitutional, and seventhe Ohio, Kentucky, Missouri, Tennessee, Mississippi, South Carolina, and Virginia - voted them to be so, of which six recommended their legalization and adoption by a change of the constitution; five, however-the New England, New York, Genesee, Philadelphia, and Baltimore-refused to take any action.

The General Conference of I 824 assembled in Baltimore with one hundred and twenty-five members. The Rev. Richard Reece, late president of the British Conference, and the Rev. John Hannah, his accredited companion, were introduced to the conference by the senior bishop. In the letter from the British Conference and in the addresses of Mr. Reece and Mr. Hannah were eulogized the spirit and communications of John Emory, who had fulfilled his mission as fraternal delegate to their conference.

The subject of church government was discussed in the episcopal address, and referred to a committee. Lovick Pierce proposed, but without effect, a plan to authorize a new restriction on the powers of the General Conference, giving the bishops, or a majority of them, a qualified veto power, and allowing them to state within 
three days their objections to any act which they deemed an infringement upon the constitution. If after receiving such communication the conference should reaffirm the said act by a majority of two thirds it should go into effect, and should it prevail by a smaller number the bishops were still to have the power to lay it before the Annual Conferences, in which case a decision of a majority should be final.

With a preamble stating that the resolutions suspended at the last General Conference " are null and void, inasmuch as a majority of the Annual Conferences have judged them unconstitutional, and whereas six recommended their adoption," it was moved that as soon as "their adoption shall be recommended by the other Annual Conferences, the same being approved by two thirds of the present General Conference, they shall go into effect."

This resolution was not carried, but a motion of David Young, with a similar preamble, resolving that the "said resolutions are not of authority and shall not be carried into effect," was passed with the narrow margin of two majority in a ballot of one hundred and twenty-four. On the last day of the session, however, a resolution was voted declaring that the suspended resolutions were "considered as unfinished business, and were not to be inserted in the revised form of the Discipline, nor carried into effect."

The conference having decided to elect two general superintendents, a ballot was taken. Joshua Soule had 64 votes, William Beauchamp 62, Elijah Hedding. 6I, and John Emory 59. On the next ballot Soule, having 65 votes, was elected by one majority; Hedding received 64, Beauchamp 62, and Emory 58. Before the third ballot Emory withdrew his name, Beauchamp had 60 votes, and Hedding, having 66 , was elected.

Soule had demonstrated himself to be the most dominating personality, except Asbury, in the history of American 
Methodism. Practically "the father of the constitution," he declined to pledge himself to comply with an unconstitutional law, resigned, and refused to withdraw his resignation, and yet, after the rancorous discussion of four years, was the first elected. He was a native of Maine, and was now in his forty-third year; he joined a Methodist class when sixteen, and began the next year to travel as the helper of an itinerant. Early spoken of as the "boy preacher," he became famous as a polemic antagonist of Calvinism, Unitarianism, and Universalism. $\mathrm{He}$ was a close student and a discursive reader and, until elected book-publisher and editor of the "Methodist Magazine," had been for several years presiding elder. After the General Conference in 1820 he was stationed in the city of New York, where he remained one year, and was then transferred to Baltimore, representing that body in the Conference of 1824 .

Elijah Hedding was a native of Dutchess County, New York, but was reared in a Vermont town, where there had been no public religious services until a Methodist family moved to the place, who were in the habit, in their own house, of reading Wesley's sermons to such a congregation as might assemble. Hedding, being a good reader, was asked to perform this service, though he made no profession of religion. In his nineteenth year he was converted, and in his twentieth was appointed to a charge vacated by Lorenzo Dow, "who left his circuit, imagining that God had called him to go to Ireland." The next year he was admitted to the New York Conference, and on its division in 1805 he became one of the New England branch. He was presiding elder of the New London district in 1809 , sat as a delegate in the General Conference of 1812 , and became renowned as a preacher and as a progressive ecclesiastical statesman. Three times he was pastor in 
Boston, and under his inspiration the conference appointed a committee, of which he was one, to consider the establishment of a weekly religious paper; and during the next year was founded "Zion's Herald," the first weekly exclusively Methodist publication in the world. The first copy measured nine by sixteen inches. At each of the four terms that Hedding had been delegate to the General Conference he had received all but two or three votes of the entire number cast. ${ }^{1}$

Beauchamp, a native of Delaware, who came so near an election, "was a man of genuine greatness, one of nature's noblemen and God's elect." He early became a Christian, was well educated, entered the ministry, and was equally popular as a preacher in Pittsburg, New York, and Boston. In 18 I 6 he took editorial charge of the "Western Christian Monitor," a monthly magazine, the only one then published in the church. He was the author of a book of essays on "The Truth of the Christian Religion," was known as " the Demosthenes of the West," and would undoubtedly have been chosen bishop had he not spent so large a portion of his life out of the itinerancy. ${ }^{2}$

Bangs was reëlected general book-steward, with Emory as assistant, and Ruter book-agent at Cincinnati.

A number of the preachers in the upper province of Canada sent a petition to the General Conference "to set them off as an independent body, with the privilege of electing a bishop to reside among them." The resolution of the conference authorized the formation of a Canada Conference, but did not concede all that was asked.

Many memorials were presented claiming for laymen the right to representation, but it was deemed inexpedient to grant their petitions.

1 "Lives of the Methodist Bishops," p. 19o.

2 Stevens's "History of the Methodist Episcopal Church," vol. iv., p. 30. 
The missions to the Indians prospered in 1824, and Peter Jones, a half-breed, English on his father's side and of the tribe of Mississagua on his mother's, became noted for preaching to the Indians and interpreting for the missionaries.

The first college organized after Cokesbury was destroyed was located at Augusta, $\mathrm{Ky}$., and was named Augusta College. It was a county academy, but by the citizens was tendered to the Ohio and Kentucky conferences in I822. J. P. Finley was principal, and in 1825 John P. Durbin was appointed professor of languages.

The Methodist Book Concern in New York began the publication of "The Christian Advocate and Journal" in I 826, issuing the first copy on the 9th of September. "The Missionary Journal," published in Charleston, S. C., preceded it for a year or two, but was merged in it, and for a time the paper bore the title, "The Christian Advocate and Journal." In August, 1828, "Zion's Herald" was consolidated with it, and for some years it was known as "The Christian Advocate and Journal and Zion's Herald." But in 1830 , a new association having been formed, the publication of the present "Zion's Herald" was begun, and that part of the title was subsequently dropped. The first editor of "The Christian Advocate and Journal" was a layman named Barber Badger.

In harmony with the original impulse of Methodism, much interest was taken in education, and in 1824 an academy was established at Cazenovia, N. Y. Maine Wesleyan Seminary at Kent's Hill was incorporated in 1827 , having previously received a gift of ten thousand dollars from Luther Samson.

The academy at New Market, N. H., was affiliated in 1826 with the Wesleyan Academy, founded in Wilbraham, Mass.; and Wilbur Fisk, who had been graduated with 


$$
8
$$




\section{.}


honor from Brown University in 1815 , studied law, but entered the Methodist ministry in 1818 , was placed in charge. The Pittsburg Conference founded at Uniontown, $\mathrm{Pa}$., an institution named Madison College, of which Henry B. Bascom was made president; but it was of short duration.

A Sunday-school Union of the Methodist Episcopal Church was established in 1827 . Its primary purpose was to encourage the formation of schools in small towns and scattered settlements, and to furnish them books suitable for libraries, and communications containing instructions for teachers.

The General Conference of I 828 met in Pittsburg. Garrettson was elected a delegate, but before the assembling of the conference died, universally beloved and honored both in church and state.

Josiah Randall, of the New England Conference, appealed from a decision expelling him on the charge of disseminating doctrines contrary to the Articles of Religion. He was said to teach that no atonement was made by Christ for the transgressions of the law, for which men are personally responsible, and that God may, upon the condition of mere acts of the transgressor, relinquish his claims and the transgressor be pardoned without an atonement. He made his defense in person, and was answered by Wilbur Fisk. Randall admitted that the case had been fairly represented, and retired; the decision expelling him was reaffirmed by a vote of one hundred and sixty-four to one.

It was reported that Soule had preached a sermon in which there was an apparent departure from several points of doctrine held by the church. The committee appointed to inquire into the matter reported that there was " nothing in the sermon of Bishop Soule preached before the South Carolina Conference and published at its 
[CHAP. Xv.

request, fairly considered, inconsistent with our Articles of Religion as illustrated in the writings of Wesley and Fletcher," and the report was adopted.

William S. Stockton, a layman of the Philadelphia Conference, began, early in $\mathrm{I} 82 \mathrm{I}$, the publication, at Trenton, N. J., of the "Wesleyan Repository." It was continued for three years, its contributors being ministers and members of the Methodist Episcopal Church. An examination of the subject of church polity was carried on in several successive numbers by Nicholas Snethen, one of the strongest of the ministers of the day, a friend and, at one time, traveling companion of Bishop Asbury. As the circulation of the "Repository" increased and its utterances became more aggressive, it encountered opposition, and gained much patronage on account of an announcement in the "Methodist Magazine" of September, I 823, that the editors could not admit to the pages of that periodical "subjects of controversy which act to disturb the peace and harmony of the church," and advising those who desired changes to address petitions to the General Conference.

A circular in response to the memorialists, issued by the General Conference of I 824 , contained this sentence: "If by rights and privileges it is intended to signify something foreign from the institutions of the church as we received them from our fathers, pardon us if we know no such rights and if we do not comprehend such privileges."

While that conference was still sitting a convention of reformers was held in Baltimore, attended by local and itinerant ministers-and including, as was affirmed, seventeen members of the General Conference-and by many laymen. It determined to establish a periodical entitled "The Mutual Rights of the Ministers and Members of the Methodist Episcopal Church," and to organize Union Societies in different parts of the country. The forma- 
tion of these and the wide circulation of "Mutual Rights" naturally excited opposition from the representatives of the constituted authorities. Dennis P. Dorsey, of the Baltimore Conference, after being left for a year without an appointment, was excluded from the church for refusing to pledge himself to desist from spreading what the conference regarded as incendiary publications. William C. Pool received the same punishment for circulating "Mutual Rights" and attending Union Meetings. 'In one month eleven local preachers and twenty-two laymen were expelled in Baltimore. These took an appeal to the district conference. Much excitement resulted, and the wives and friends of those who had been ejected, in all fifty women, withdrew from the Methodist Episcopal Church.

A convention of reformers assembled in Baltimore in I 827 and prepared a memorial to the next General Conference and an address to the public.

The complication of Hedding with the controversy diverted attention from principles to persons. $\mathrm{He}$ had delivered an address to the Pittsburg Conference on the duty of Methodist ministers with reference to current discussions of church reform, and one of the members of that body reported his remarks in "Mutual Rights," and, in the opinion of the bishop, traduced him; whereupon he demanded reparation from that paper, and, the response not being satisfactory, he laid the matter before the General Conference. It was referred to a committee, before which appeared the bishop, the writer of the article, and the delegates from the Pittsburg Conference. The report adopted by the conference thus exonerated the bishop: "The address of Bishop Hedding, as recalled by himself and the delegates of the Pittsburg Conference, not only was not deserving of censure, but was such as the circum. stances of the case rendered it his official duty to deliver." 
The conference was obliged to consider the case of Dennis P. Dorsey, who, when tried before the Baltimore Conference, made declarations which that body could not approve. The judgment pronounced was that he should be reprimanded by the bishop and left for one year without an appointment. He appealed, but, in public speeches and through the columns of "Mutual Rights," denounced the action, instead of waiting in silence till the General Conference. On this account he was expelled in 1828 . He now presented two distinct appeals: first, from the action reproving and suspending him; and second, from the decision by which he was expelled. His plea on the first issue was not admitted, but the second was discussed at length. Asa Shinn, a pleader of unusual power in statement, and eloquent withal, argued the case for the appellants. Pool also had appealed.

The delegation of the Baltimore Conference responded to Shinn's statement of facts and argument, and Fisk took part in the debate, speaking at great length, as did Emory. The result was that the decisions expelling Dorsey and Pool were reaffirmed; but a publication was made by the conference of the grounds of its action, affirming that it could not justly be construed as denying to minister or member of the Methodist Episcopal Church any liberty of speech or of the press consistent with moral obligations as Christians and the associate obligations of Methodists, and affectionately appealing to brethren to desist from patronizing and circulating such publications as the "Mutual Rights," and proposing that no further prosecution be instituted against any minister or member on the ground of past agency in the matter, and, with certain qualifications, allowing a period of six months for the acceptance of the amnesty or the conditions.

Snethen, who had located, took large part in these contro- 
versies prior to the General Conference of 1828 , becoming the most aggressive of the opponents of the existing order. To meet him Thomas E. Bond, a local preacher and practicing physician of Baltimore, issued an appeal to the Methodists in opposition to the changes proposed in their church government, his book being dedicated to Snethen. Alexander McCaine, a former secretary of the General Conference, published a work called "History and Mystery of Methodist Episcopacy." To him Emory replied to the satisfaction of all who held to the old ways, and to the disgust of those who had committed themselves to reform.

The expelled members and their sympathizers, assembled in Baltimore in November, 1827, formed a society called "Associate Methodist Reformers," and prepared a memorial to the approaching General Conference. To it the conference replied in a report prepared by John Emory, designed to show that the various demands of the reformers were not founded on natural or acquired right, and were of such a character that if granted they would undermine the practical system which had given to Methodism its success. The report charges that the organization of Union Societies was the source of the principal evils.

The reformers were most numerous in New York, Philadelphia, Baltimore, Pittsburg, and Cincinnati. They applied the title of Old Side to those who adhered to the Methodist Episcopal Church. Early in 1828 charges were brought against various ministers who refused to receive the overtures of the General Conference. While some were expelled, many withdrew, taking with them classes and leaders, leaving church property behind, but proceeding at once to gather funds to buy and build. Two local preachers and nine laymen, stewards, elders, and exhorters, were cut off before the close of the year in Lynchburg, Va. This was followed by a large secession. Similar difficul- 
ties occurred in North Carolina. A general convention of Methodist reformers assembled in Baltimore in November, and soon afterward conferences were organized in different States, so far as possible in harmony with the principles of the Methodist Episcopal Church, except in the points. upon which the reformers had taken issue.

An association was formed in Pittsburg including a large number of members. After many such combinations had been effected a general convention assembled in Baltimore, November 2, I830, to frame a constitution and discipline, a draft having been previously prepared by a committee. It was adopted after amendment. The new denomination was styled the Methodist Protestant Church.

The point of controversy, reduced to its last analysis, was declared by the reformers to be a pure and unmixed question of representation of the laity in the Annual and General Conferences. Yet it was complicated with other questions, and these occupied a prominent part in the discussion. The reformers were strongly opposed to episcopacy, and the book issued by McCaine was well calculated to create personal feeling that could not be allayed. They were also opposed to the presiding eldership.

One of the most distinguished of their early ministers, Truman Bishop, M.D., for a number of years had been a superannuated member of the Ohio Conference; first locating, he withdrew from the denomination. He experienced much mental anxiety on account of his relations to the church, and died soon after he took this step. Asa Shinn had been insane for nearly a year, but upon the death of Bishop, having recovered, went to Cincinnati and took charge of the church which had enjoyed the services of Bishop, for this purpose withdrawing from the Pittsburg Conference of the Methodist Episcopal Church. 
He preached the dedicatory sermon of the new church, and under his superintendence the society prospered, as did the whole movement everywhere. In four years the number of members reported from the fourteen conferences was 26,587 .

Although the territory of Canada had been amicably divided with the Wesleyan connection, leaving Upper Canada under the superintendence of the Methodist Episcopal Church, the troubles in that country continued. The preachers, having chiefly emigrated from the United States, were denied certain privileges enjoyed by natives and by ministers from England, and the celebration of matrimony was especially embarrassed. A solemn appeal therefore was made by the Canada Conference to the General Conference of 1828 for release from responsible connection with it; this was referred to a committee of seven, of which Bangs, who in his early ministry had endured much hardship in Canada, was appointed chairman.

On the report of this committee the conference adopted a plan to allow Annual Conferences in Upper Canada to elect a general superintendent for the Methodist Episcopal Church in that province, and to authorize the general superintendents in the United States to ordain him; and by another resolution it provided for furnishing the periodicals published by the Methodist Book Concern on the same terms as were allowed to Methodists in the United States, and ordered that if the Canadian Conference continued to patronize the Methodist Book Concern they should receive an equal appropriation of any annual dividend which might be made by the Book Concern to the several Annual Conferences respectively.

"When the subject first came up for consideration," says Bangs, "it was contended, and the committee to whom 
it was first referred so reported, which report was approved by a vote of the General Conference, that that body had no constitutional right to set off the brethren in Canada as an independent body, because the terms of the contract by which the General Conference existed made obligatory on it as a delegated body to preserve the union entire, and not to break up the church into separate fragments."

Emory, however, proposed a way out of the difficulty based upon the assumption that the preachers who went to Canada from the United States did so in the first instance as missionaries, and that ever afterward, when additional help was needed, Asbury and his successors asked for volunteers, not claiming the right to send them in the same authoritative manner in which they were appointed to the different parts of the United States. From this Emory deduced the doctrine that it was perfectly compatible with the powers of the delegated General Conference, thus connected by a voluntary or conditional contract either expressed or implied, to dissolve the connection. Bangs states that the agreement was based wholly on this principle. ${ }^{1}$ It was stipulated that any bishop ordained for Canada under the agreement should not be allowed to exercise episcopal functions in the United States.

The conference was flooded with memorials concerning speculative freemasonry. These were referred to a special committee, but the conference wisely refused to make a deliverance upon a subject of which it could not acquire sufficient knowledge to test the nature and tendency of the organization, and whose members it could not condemn so long as they comported themselves in harmony with the rules of the church.

There were also many petitions concerning ardent spirits.

1 " History of the Methodist Episcopal Church," vol. iii., pp. 390-392. 
On motion of Wilbur Fisk a very moderate resolution was passed:

"Whereas, The rules and examples of the Wesleyan Methodists from the commencement of their existence as a people, both in Europe and America, were calculated to suppress intemperance and to discountenance the needless use of ardent spirits; and

"Whereas, The public mind in our country for a few years past has been remarkably awakened to a sense of the importance of this subject; therefore

"Resolved, I. That we rejoice in all the laudable and proper efforts now making to promote this just object, so important to the interest both of church and nation.

"Resolved, 2. That all our preachers and people be expected, and they are hereby expected, to adhere to their first principles as contained in their excellent rules on this subject, and as practiced by our fathers, and to do all they prudently can, both by precept and example, to suppress intemperance throughout the land.

"Resolved, 3. That, to bring about the reformation desired on this subject, it is important that we neither drink ourselves (except medicinally) nor give it to visitors or workmen."

Wilbur Fisk and William Capers were elected fraternal delegates to the British Conference.

When the General Conference of 1832 assembled in Philadelphia, its members deplored the absence of Bishop George, who had closed his laborious and exemplary life September 23, I 828 .

Great was the rejoicing over the denominational returns. In the four years preceding the close of 1831 there had been an addition of I 3 I, I I 7 members and 434 ministers; giving a total of 5I3, I I 4 members and 2010 ministers.

An important change was made in the sixth restrictive 
rule, so as to make it possible, upon the concurrent recommendation of three quarters of the members of the Annual Conferences present and voting, for a majority of two thirds of the next General Conference to alter any of the restrictive rules except the first. It was also provided that when two thirds of a General Conference shall have recommended the same, and three quarters of the members of the ensuing Annual Conferences present and voting shall concur, such alterations shall take effect.

James Osgood Andrew of the Georgia, and John Emory of the Baltimore, Conference, were elected bishops, 223 ballots being cast, each bearing two names; Andrew had I 40 and Emory I 35 votes. Andrew was the son of a Methodist preacher, and was born in 1794 ; he entered the South Carolina Conference at eighteen, and though having little education when he began to preach, his improvement was constant; he was equally ingratiating in private and in public, and, while eloquent on all occasions, such was his devotion to the cause of missions that in speaking. upon that theme he seemed to surpass all previous efforts. "In the heated strife of 1820 and 1824 he had so borne himself as not to incur the enmity of the progressives." 1

William Capers was probably the most popular preacher in the South. At a meeting of delegates to consider candidates, he was asked to allow his name to be presented for the office of bishop, but he declined, stating that he was " unwillingly a slave-holder, and that he did not wish to be brought into antagonism as a candidate with Andrew, whom he suggested as suitable for the office." Andrew was not a slave-holder, neither was his father; therefore there appeared no danger that he would inherit slaves. This statement greatly contributed to the large vote which Andrew received.

1 Smith's " Life and Letters of J. O. Andrew," p. 230. 



$$
\text { • }
$$


Emory was a native of Maryland, the son of a man noted for industry, honesty, and decision of character and for usefulness as a class-leader. His mother was reared in the English church, but shortly before her marriage had become a Methodist. Emory's father, having occupied various judiciary positions, designed his son for the profession of law. His progress was so rapid that he was admitted to the bar in his nineteenth year. Against the wish of his father he yielded to a call to preach, which so bitterly disappointed the former that years elapsed before he became sufficiently reconciled to consent to hear his son preach, and did not express himself as fully conciliated until he approached death.

Emory was elected to the first General Conference to which he was eligible, that of $\mathrm{I} 8 \mathrm{I} 6$. He was corresponding secretary of the newly formed Missionary Society, and was chosen a delegate to the General Conference of I820. That body having directed that a delegate be sent to the British Conference to settle difficulties rising out of the Canada question, the bishops selected Emory. His subsequent career increased the respect in which he was held. On account of his advocacy of the election of presiding elders he was not returned to the General Conference of I 824, but notwithstanding this he was appointed its secretary, and had he received six votes additional to those given him would have been elected bishop. $\mathrm{He}$ was made assistant book-agent in 1828 , in which office, as everywhere, he was successful. His services in the controversy which led to the establishment of the Methodist Protestant Church and his election to the episcopacy gave general satisfaction.

Having failed to secure from the preceding conference a condemnation of freemasonry, the petitioners now asked for decided action on secret societies, but the committee 
to whom the memorials were referred declined to act, on the ground that "the very attempt might involve serious difficulties."

John P. Durbin was elected editor of the "Christian Advocate and Journal and Zion's Herald," the "Youth's Instructor," the "Child's Magazine," tracts and Sundayschool books. The "Methodist Magazine" was transformed into the "Quarterly Review" in I830, and the book-agent, Emory, edited it until this conference, when Nathan Bangs succeeded him.

At the General Conference Rev. Melville B. Cox volunteered to go as missionary to Liberia, and was gladly accepted by the bishops. He arrived in Liberia on the 8th of March, I 833, and was cordially received by Acting Governor Williams, a local preacher of the Methodist Episcopal Church. He held a camp-meeting on the next day, and on the 6th of April opened a Sunday-school; on the 9th the Methodists in Liberia, consisting of emigrants to that colony from the United States, signed articles of agreement resigning the superintendency of all the churches in that country, adopting the Articles of Religion, General Rules, and moral discipline of the Methodist Episcopal Church of the United States of America, acknowledging the authority of the General Conference, and requesting the ordination of Williams, who had been duly recommended, as deacon and elder.

Three days later Cox was attacked by the dreaded African fever, and when supposed to have recovered, relapsed, lingering until the 2 Ist of July, when he died. Just before sailing for Liberia he was asked what he would like inscribed upon his tombstone should he die in Africa. He responded, "Let thousands fall before Africa be given up." Although the denomination was greatly depressed by his death, its missionary fervor was increased. 


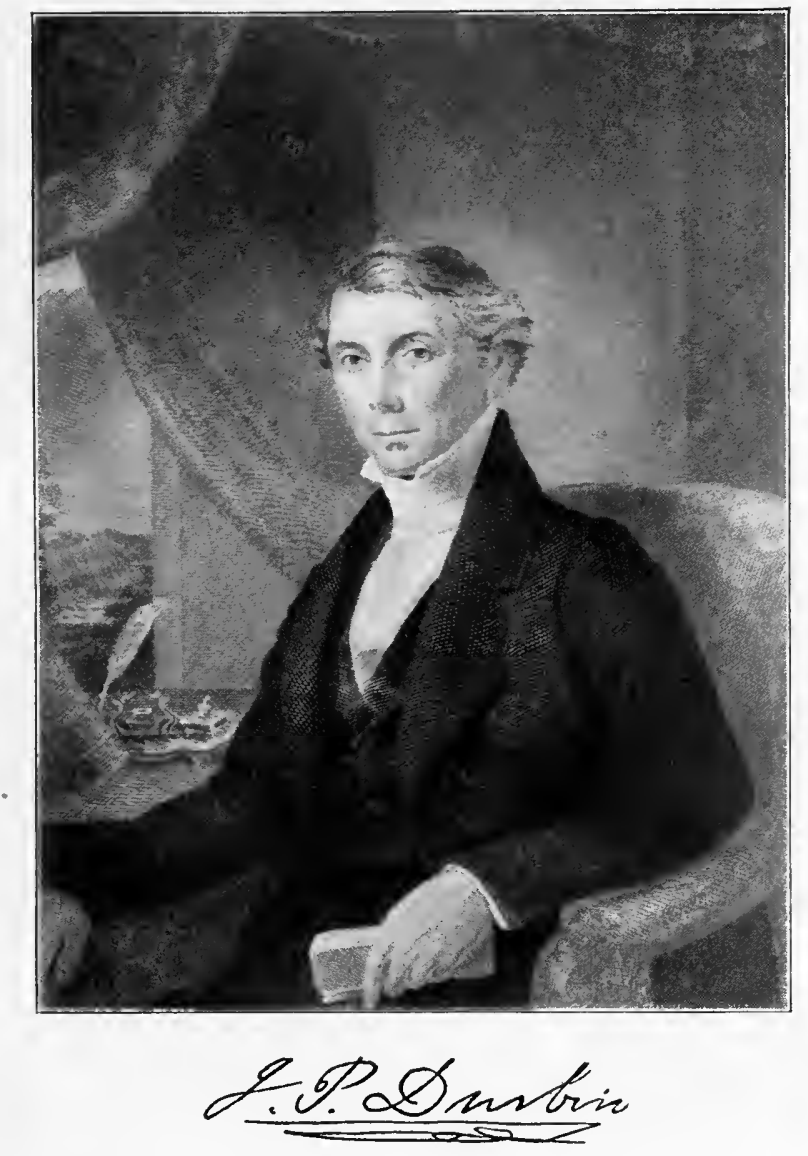


Wesleyan University is the oldest institution of the highest grade founded by American Methodism. Certain buildings erected for a military academy in I 825 at Middletown, Conn., were transferred to the trustees in I 830, at which date a preparatory school was opened. The university proper, having been chartered in $183 \mathrm{I}$, received students in the fall of the same year, under the presidency of Wilbur Fisk. The condition on which the property had been transferred was that the church should furnish an endowment of forty thousand dollars. The New York and New England conferences accepted the proposition and raised the amount. The Genesee Conference Seminary at Lima, N. Y., was also established in $183 \mathrm{I}$.

The Virginia Conference founded Randolph Macon College in 1832; and the next year Dickinson College, at Carlisle, Pa., established fifty years before, was transferred to the Baltimore and Philadelphia conferences of the Methodist Episcopal Church, and John P. Durbin was called to the presidency. It was opened for students in 1834 , fortyfive thousand dollars in donations and subscriptions having been received.

Allegheny College, at Meadville, Pa., an institution which was chartered in 1815 but which had become moribund from lack of support, was resuscitated in I 834 , and its grounds and buildings given to the Methodist Episcopal Church and adopted by the Pittsburg and Erie conferences. Martin Ruter was the first president. The Vermont Methodist Seminary and Female College was established in 1834 , and such was the interest in education that at the close of that year there were twenty academies under the patronage of the denomination, and, besides the colleges already founded, the Illinois Conference founded on the 20th of February, 1828 , a seminary at Lebanon, Ill., twenty-four miles east of St. Louis. The first resolution concerning it 
was moved by Peter Cartwright. It opened that year under the name of Lebanon Seminary, Edward R. Ames, principal. It relied for support upon the whole territory west of the State of Ohio and north of the Ohio River. Bishop McKendree, in I 830, made a gift to the institution of four hundred and eighty acres of land, and its name was then changed from Lebanon Seminary to McKendree College, though its charter as a collegiate institution was not given until I 834. Soon after this Peter Akers was elected president.

The General Conference of I 832 authorized the establishment of the "Western Christian Advocate" at Cincinnati, Thomas A. Morris being appointed editor. The Pittsburg "Christian Advocate" was established in I 833 by the Pittsburg Conference, with Charles Elliott as editor.

Additional missionaries were sent to Liberia in 1834 . Within four months the wife of one of the missionaries died, and soon afterward her husband; in less than a year eight missionaries from this country had died, several of whom were Presbyterians, and one an Episcopalian. Lieutenant-Governor Williams visited the United States during this year, and was ordained deacon and elder by Bishop Hedding. The Rev. John Seys was appointed superintendent of the mission, and arrived in Africa on the 18 th of October, accompanied by Francis Burns, a young colored preacher. Liberia now seemed destined to a career of prosperity. ${ }^{1}$

Missions to the Flathead Indians were established, and the brothers Jason and Daniel Lee and their colleagues began work in Oregon.

Bishop McKendree died at Nashville, Tenn., on the $5^{\text {th }}$ of March, I835. He is worthy of being ranked next to

1 J. M. Reid's "Missions and Missionary Society of the Methodist Epis. copal Church," vol. i., p. 142 . 


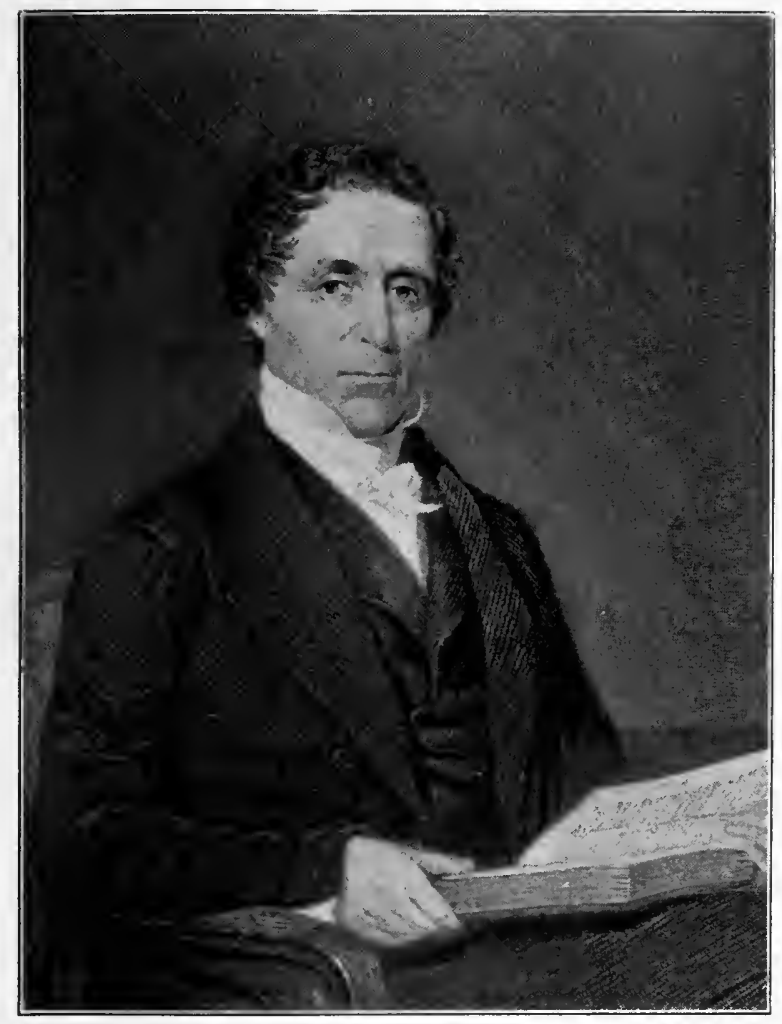

PETER AKERS. 
Asbury in helpfulness to early Methodism. He had long been in failing health, and the church received the intelligence of his death with sadness, but without surprise.

Bishop Emory, on the 16 th of December in the same year, started from his home in a light carriage to go to Baltimore. Shortly afterward he was found by the roadside about two miles from his home insensible, with a fractured skull. $\mathrm{He}$ remained unconscious until his death in the evening. It was supposed that he was thrown out while descending a hill. In temperament, ability, and accomplishments he differed from all his episcopal colleagues and predecessors; he resembled Wesley in system, administrative ability, and mental clearness; and in general information and scholarship he was far superior to any Methodist of his time except Wilbur Fisk. His tragical end gave the church a severe shock, and for years the mention of his name in a public congregation elicited manifestations of sorrow.

The buildings of the Book Concern with the entire stock were destroyed by fire on the I8th of February, I 836 . The loss was estimated at a quarter of a million dollars. A collection was made amounting to more than eighty-eight thousand dollars, which, added to the insurance and the value of the ground, aggregated two hundred and eightytwo thousand dollars. With this were procured buildings far better than the former, and machinery of the most improved type.

The General Conference of 1832 recommended the bishops and the Missionary Society to establish missions in South America, and advised the appointment of a suitable person to travel there and report upon the condition and needs of the people. Soon afterward a member of the Methodist Episcopal Church who had settled in Buenos Ayres and succeeded in forming a small class petitioned for a missionary. In July, I835, the bishops directed the 
Rev. Fountain E. Pitts, of the Tennessee Conference, to make the tour. He visited Rio de Janeiro, Montevideo, Buenos Ayres, and other places, and after forming several societies returned to this country. ${ }^{1}$ On invitation of the General Conference Pitts reported in person the results of this tour.

The General Conference of 1836 convened in Cincinnati, Roberts, Soule, Hedding, and Andrew being present. William Lord, delegate from the Wesleyan connection, and William Case, delegate from the Wesleyan Methodist Church in Upper Canada, addressed the conference. The address sent by the British Conference took strong antislavery ground and stirred opposition. Bangs, Capers, and Morris were appointed a committee to prepare a reply. An abolition meeting was held in Cincinnati on Tuesday, May roth, and George Storrs of New Hamphire and Samuel Norris from Maine, delegates to the General Conference, delivered addresses. Two days later resolutions were introduced which provoked debate, in which Orange Scott, of the New England Conference, took the most uncompromising abolition grounds. As finally adopted they were:

"Resolved by the delegates, That they disapprove in the most unqualified sense the conduct of the two members of the General Conference who are reported to have lectured in this city, Cincinnati, recently upon, and in favor of, modern abolitionism.

"Second, That they are decidedly opposed to modern abolitionism, and wholly disclaim any right, wish, or intention to interfere with the civil and political relation between master and slave as it exists in the slave-holding States of this Union.

"Third, That the foregoing preamble and resolutions be published in our periodicals."

1 J. M. Reid's “ Missions and Missionary Society of the Methodist Episcopal Church," vol. i., p. 232. 
For these resolutions one hundred and twenty votes were cast, and the largest number cast against them at any stage was fourteen.

On the general subject of slavery the conference resolved that "it is inexpedient to make any change in our book of Discipline respecting slavery, and that we deem it improper, therefore, to agitate the subject in the General Conference at present."

Three bishops were chosen, Beverly Waugh, Wilbur Fisk, and Thomas A. Morris. Waugh was a Virginian, forty-seven years of age. He entered the Baltimore Conference in his twentieth year, and, having been successful as pastor and presiding elder, in 1828 he was made assistant editor and book-agent, and in 1832, when Emory became bishop, though not a delegate to the conference, was elected senior book-agent.

When chosen bishop, Fisk was in England as delegate to the British Conference.

Thomas A. Morris was forty-two years of age, had served twenty years as pastor and presiding elder, and during two years preceding his election to the episcopacy had been editor of the "Western Christian Advocate." He was a Virginian, served in the militia six months in a war with the British and Indians, decided upon the legal profession, became in religion a skeptic, but was reclaimed therefrom and converted. He inclined to join the Baptist Church, of which his parents were members, but after a period of hesitation and debate became a Methodist. As a preacher he was unpretentious in manner, but noted for common sense and a mastery of Anglo-Saxon.

Charles Elliott was elected editor of the "Western Christian Advocate," Nathan Bangs corresponding secretary of the Missionary Society, Samuel Luckey editor of the "Christian Advocate and Journal" and "Quarterly 
Review," with John A. Collins as assistant. Official " Advocates" were established at Charleston, S. C., Richmond, Va., Nashville, Tenn.

The conference decided that an Annual Conference might locate members without their consent, and that the Discipline did not allow them an appeal. To establish a uniform proceeding in such cases a form of trial was enacted.

Fisk, on his return from Europe, declined the office of bishop, assigning the state of his health, and his belief that he could accomplish more for the church as president of Wesleyan University than was possible in any other position.

Justin Spaulding, of the New England Conference, sailed for Rio Janeiro, Brazil, on the 22d of March, 1836, being sent out by appointment of the bishop. He had the missionary spirit, and had previously offered himself for Oregon. John Dempster sailed for Buenos Ayres in October of the same year. Spaulding preached to the English and American portion of the population, but distributed the Scriptures in the Portuguese language, with which the American Bible Society gratuitously furnished him. His reports were so favorable that Daniel P. Kidder, accompanied by two teachers, went on November I 2, I837, to reinforce him. Kidder speedily mastered the Portuguese language, and did much good, although the laws of the country would not allow him to preach to the natives in their own tongue. Dempster had succeeded so well that in less than a year the people subscribed fifteen hundred dollars toward a church, and the Missionary Society appropriated ten thousand dollars to meet the additional expense necessary for its erection.

Missions were established in Texas in 1837. Martin Ruter resigned his presidency of Allegheny College and, accompanied by two preachers, entered upon his work as 


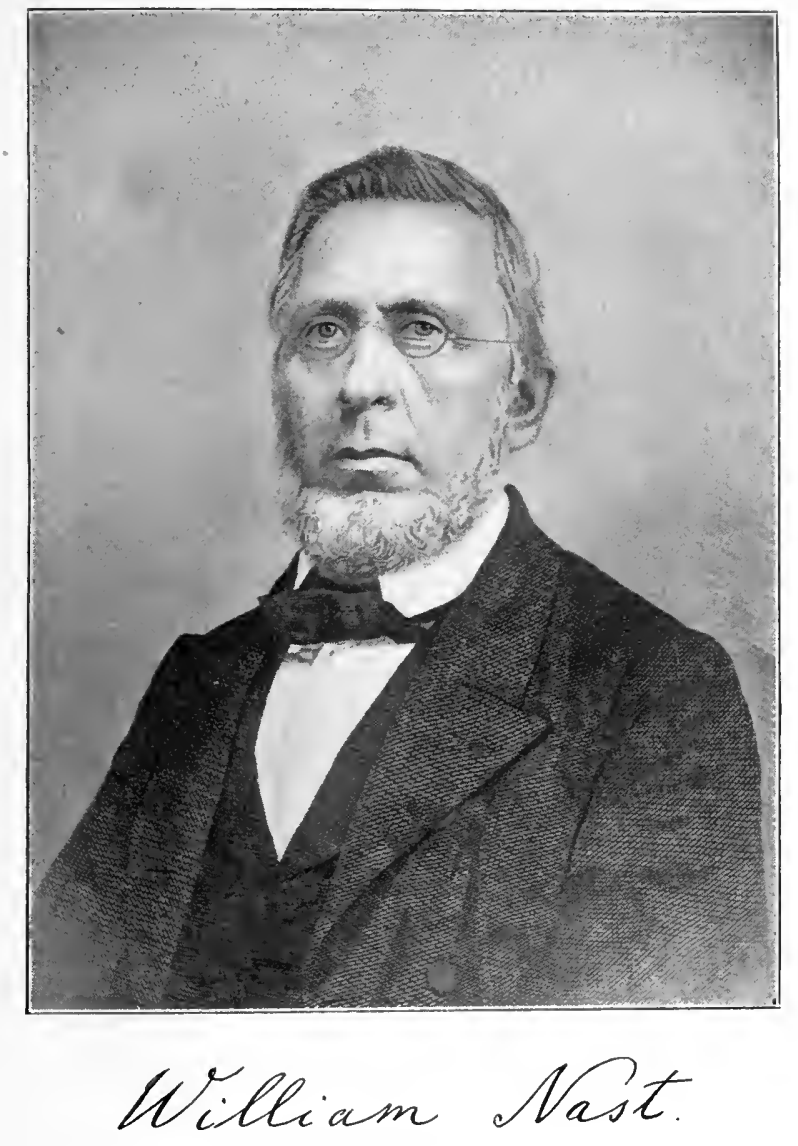




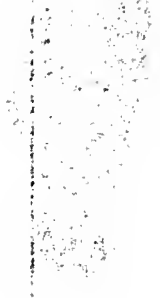


missionary. Texas had been visited as early as 18 i 9 by Methodist preachers, the most conspicuous of whom was William Stevenson. John B. Denton and E. B. Duncan were appointed to the Sulphur Forks circuit in I835. Denton, taught by his wife, learned his letters at night by the light of blazing pine-knots. A historian of Methodism in Texas says that the people of Virginia were not more surprised at the eloquence of Patrick Henry in the Tithe suit than were the Arkansans by the oratorical powers of this unlettered frontiersman. He soon gave up preaching in order better to support his family, and became a lawyer; but as he prospered and paid off his debts he determined to reënter the itinerancy, which he did, and crossed into Texas in company with Littleton Fowler. An Indian raid prevented the camp-meeting from being held. A company of citizens collected to pursue the savages. Denton, the natural leader, was riding in advance when an Indian rose in a thicket and fired at him, and he fell, mortally wounded. ${ }^{1}$

Rutersoon preached before the Texas congress, consulted with leading men, laid plans to establish a college, and traveled day and night. He collected the names of three hundred persons who had been Methodists before coming to Texas, and decided that he needed twelve additional missionaries; but his exposures and labors proved too severe, and he died May 16, I838.

Abel Stevens arrived in Texas in 1839 , with the Rev. Mr. Hoss, agent of the American Bible Society. Stevens remained several months and preached with great acceptability, and then "returned to the North to become the historian of Methodism."

William Nast, a native of Stuttgart, Germany, born in I 807, who had studied theology and philosophy, came to

1 H. S. Thrall's "History of Methodism in Texas" (Houston, Tex., 1872 ). 
the United States at the age of twenty-one. He supported himself for a time as a private teacher, and later taught German at West Point. He was then a rationalist, but became interested in Law's "Call to the Unconverted" and Taylor's "Holy Living," adopted Methodist views, and, after acting as professor of modern languages at Gettysburg Lutheran Seminary, was chosen professor of Greek and Hebrew at Kenyon College, Ohio. He was received on trial in the Ohio Conference, and appointed German missionary to Cincinnati in 1835 . The next year the German missions were organized by the Missionary Society. In January, I 839, the Western Book Concern issued "Der Christliche Apologete," with Nast as editor.

Emory College, in Georgia, was chartered early in 1837 .

The first centenary of Methodism was celebrated in I839. The day fixed was the 2 I st of October, which commemorated the forming of the first Methodist class. Sermons, however, were delivered on the previous day preparatory to collections for missions, education, and for the superannuated preachers. About one half was to be devoted to the needy ministers, one fifth to the support of missions, and the remainder to education. The amount subscribed was not far from six hundred thousand dollars, and the celebration exerted a highly beneficial influence upon all the interests of Methodism.

The Indiana Asbury University, founded by the Indiana Conference, which at that time included the State, had been opened in 1836 as a preparatory school, but was fully organized in 1838 as a university, and Matthew Simpson, A.M., its first president, entered upon his duties in April, I839. ${ }^{1}$

At the General Conference of 1840 , which met in Bal-

1 Professor George L. Curtiss's " Manual of Methodist Episcopal Church History" (Hunt \& Eaton). 
timore, a profound impression was made by the personal communications and public addresses of Robert Newton, fraternal delegate from the British Conference, and great interest elicited by the presence of Joseph Stinson, representative from the Canada Conference, accompanied by four members of that body.

The address of the bishops displayed statesmanlike ability in the discussion of church government and the institutions and enterprises of Methodism. It may be doubted if an abler document was ever presented to an ecclesiastical body.

The conference decided two grave principles of administration: First, that it is the prerogative of the bishop to decide questions of law in an Annual, subject to an appeal to the General, Conference; but the application of the law is with the former. Second, that it belongs to the president of a Quarterly Meeting to decide questions of law in the Quarterly Conference, subject to an appeal to the president of the next Annual Conference; but the application of the law shall be with the former. The conference also decided that the president of an Annual or a Quarterly Conference had the right to decline putting a motion or resolution to vote if he considered it foreign to the proper business or inconsistent with constitutional provisions, and also to adjourn a conference without a formal vote. ${ }^{1}$

An attempt had been made to substitute. Wesley's rule on temperance for the one in the Discipline. Two thousand and eighty ministers were present in the Annual Conferences and voted on the resolution authorizing the General Conference to make the change, and all but three hundred and six voted in the affirmative; but the committee of the General Conference to which the subject was submitted reported against the change, interpreting the law

1 Bangs, "History of the Methodist Episcopal Church," vol. iv., p. 396. 
to mean that three quarters of the members in every Annual Conference must be in favor of the contemplated measure before it could be lawfully carried into effect.

The Sunday-school Union was organized according to the principles of a new constitution. The American Colonization Society was almost unanimously approved and commended to the patronage of Methodists.

The pastoral address to the church deplored the decline of attendance on class-meetings, especially condemned novels, and exhorted parents to dedicate their infant offspring to God in holy baptism. 


\section{.}





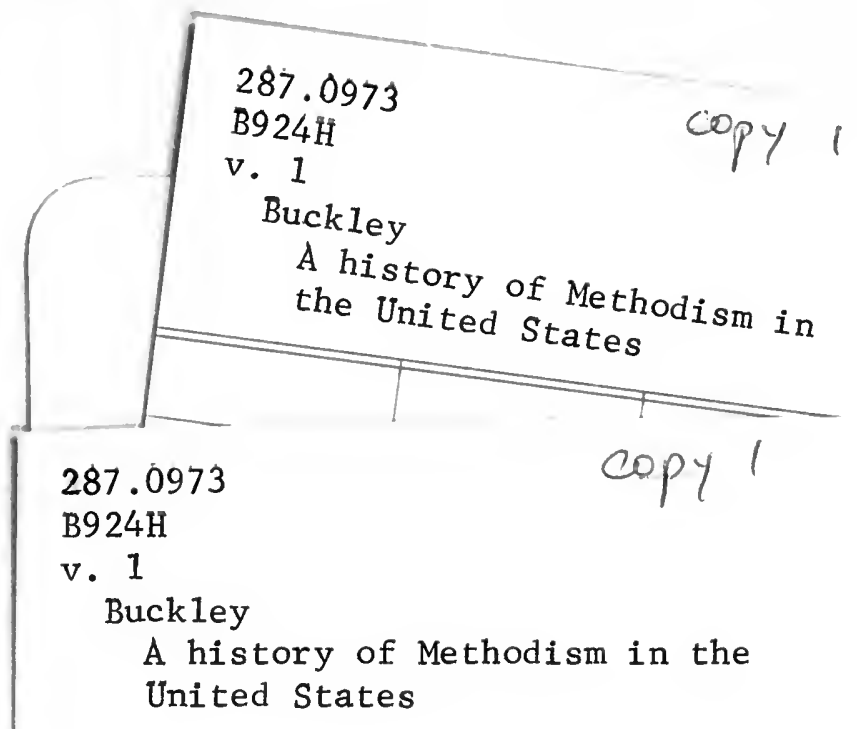


al (1)

nes. -2

12

1.5 .35

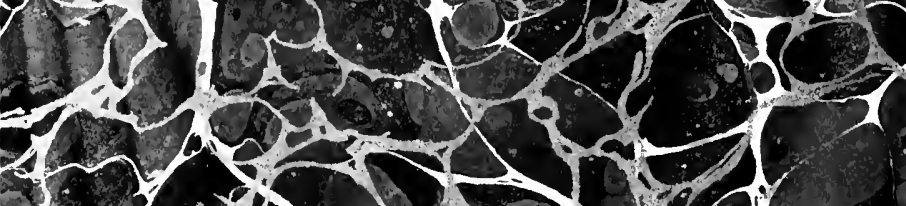

1)

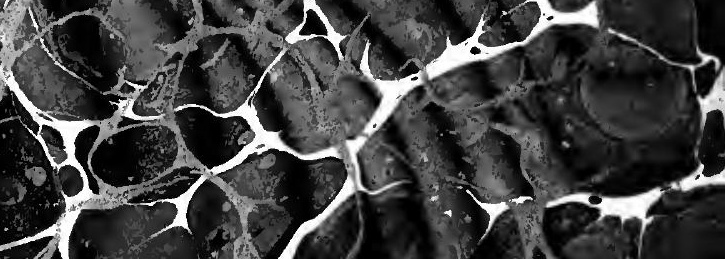

$301 \times 1$

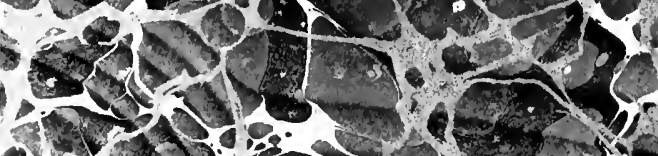

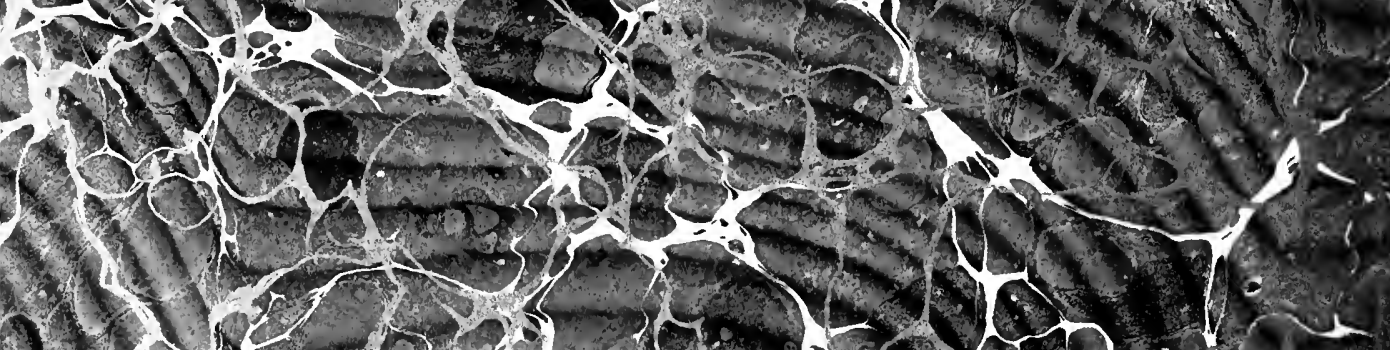

4

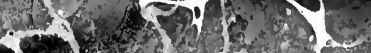

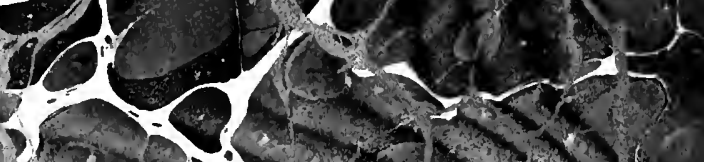

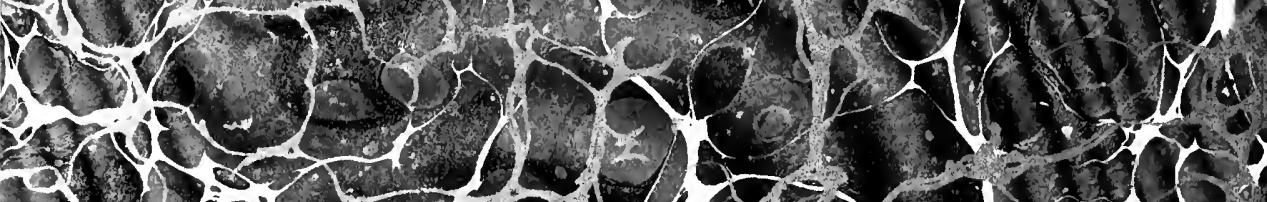

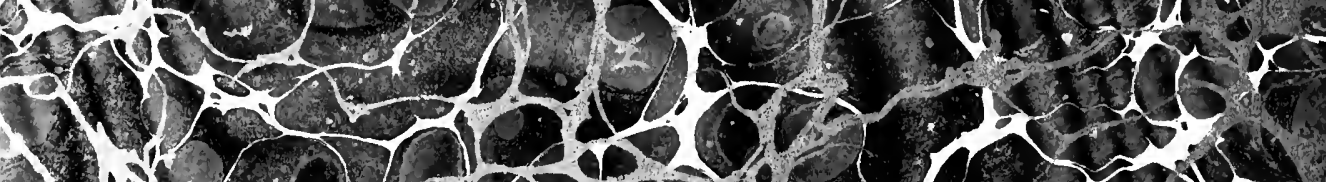

1). 0.000

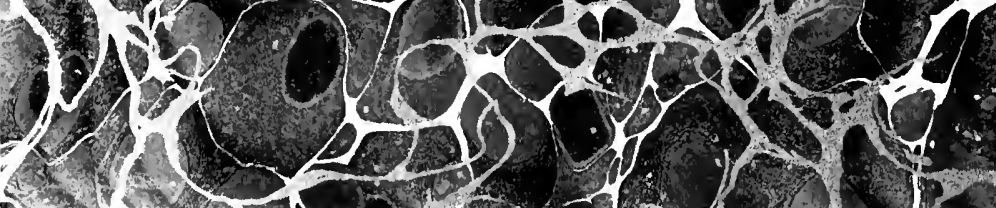

$\rightarrow$ i:

ive

$-2=-1.50$

(

(1)

)

is

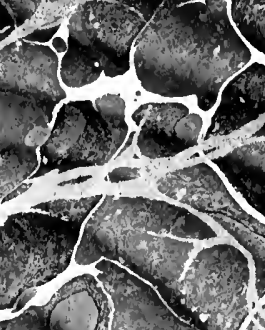

i

- 12 . 10

$5 \times$<smiles>c1ccccc1</smiles> 


\section{- I A Rorl}

16 - 1.5

4 - 125 ali. 1
$+\mathrm{u}^{2}$ 5. 
